\title{
Gezondheidsbevordering voor-en-door de doelgroep : theoretische onderbouwing en evaluatie bij migranten en ouderen
}

Citation for published version (APA):

Voorham, A. J. J. (2003). Gezondheidsbevordering voor-en-door de doelgroep : theoretische onderbouwing en evaluatie bij migranten en ouderen. [Doctoral Thesis, Maastricht University]. GGD Rotterdam e.o. https://doi.org/10.26481/dis.20031114av

Document status and date:

Published: 01/01/2003

DOI:

10.26481/dis.20031114av

Document Version:

Publisher's PDF, also known as Version of record

Please check the document version of this publication:

- A submitted manuscript is the version of the article upon submission and before peer-review. There can be important differences between the submitted version and the official published version of record.

People interested in the research are advised to contact the author for the final version of the publication, or visit the DOI to the publisher's website.

- The final author version and the galley proof are versions of the publication after peer review.

- The final published version features the final layout of the paper including the volume, issue and page numbers.

Link to publication

\footnotetext{
General rights rights.

- You may freely distribute the URL identifying the publication in the public portal. please follow below link for the End User Agreement:

www.umlib.nl/taverne-license

Take down policy

If you believe that this document breaches copyright please contact us at:

repository@maastrichtuniversity.nl

providing details and we will investigate your claim.
}

Copyright and moral rights for the publications made accessible in the public portal are retained by the authors and/or other copyright owners and it is a condition of accessing publications that users recognise and abide by the legal requirements associated with these

- Users may download and print one copy of any publication from the public portal for the purpose of private study or research.

- You may not further distribute the material or use it for any profit-making activity or commercial gain

If the publication is distributed under the terms of Article 25fa of the Dutch Copyright Act, indicated by the "Taverne" license above, 
Gezondheidsbevordering voor-en-door de doelgroep Theoretische onderbouwing en evaluatie bij migranten en ouderen 


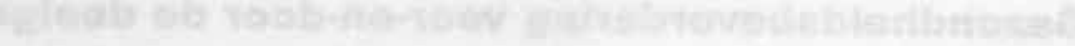

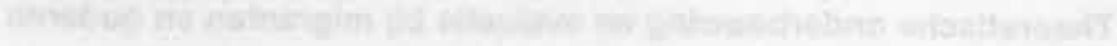




\section{Gezondheidsbevordering voor-en-door de doelgroep}

\section{Theoretische onderbouwing en evaluatie bij migranten en ouderen}

\section{Proefschrift}

ter verkrijging van de graad van doctor aan de Universiteit van Maastricht, op gezag van de Rector Magnificus, Prof. Dr A.C. Nieuwenhuijzen Kruseman, volgens het besluit van het College van Decanen, in het openbaar te verdedigen op vrijdag 14 november 2003 om 12.00 uur door Anthonius Johannes Joachim Voorham 


\section{Promotores:}

Prof. Dr G.J. Kok

Prof. Dr F. Sturmans

\section{Beoordelingscommissie:}

Prof. Dr N.K. de Vries (voorzitter)

Dr. P. van Assema

Prof. Dr B. van de Borne

Prof. Dr H.F.L. Garretsen (Katholieke Universiteit Brabant)

Prof. Dr T.G.W.M. Paulussen (Katholieke Universiteit Nijmegen)

Het verschijnen van dit proefschrift werd mede mogelijk gemaakt door de steun van de Nederlandse Hartstichting. GGD Nederland, Zilveren Kruis Achmea, Novo Nordisk en de GGD van Rotterdam.

Uitgave van GGD Rotterdam e.o.

Postbus 70032

3000 LP Rotterdam

Te bestellen bij de GGD Rotterdam e.o.

ISBN 90-807733-4-4

Vormgeving: Grafisch Bureau DUS, Linda Zoon

Druk: Edauw \& Johannissen

Fotografie omslag: Rick Keus e.a.

Fotobewerking: Fiep van den Berg 


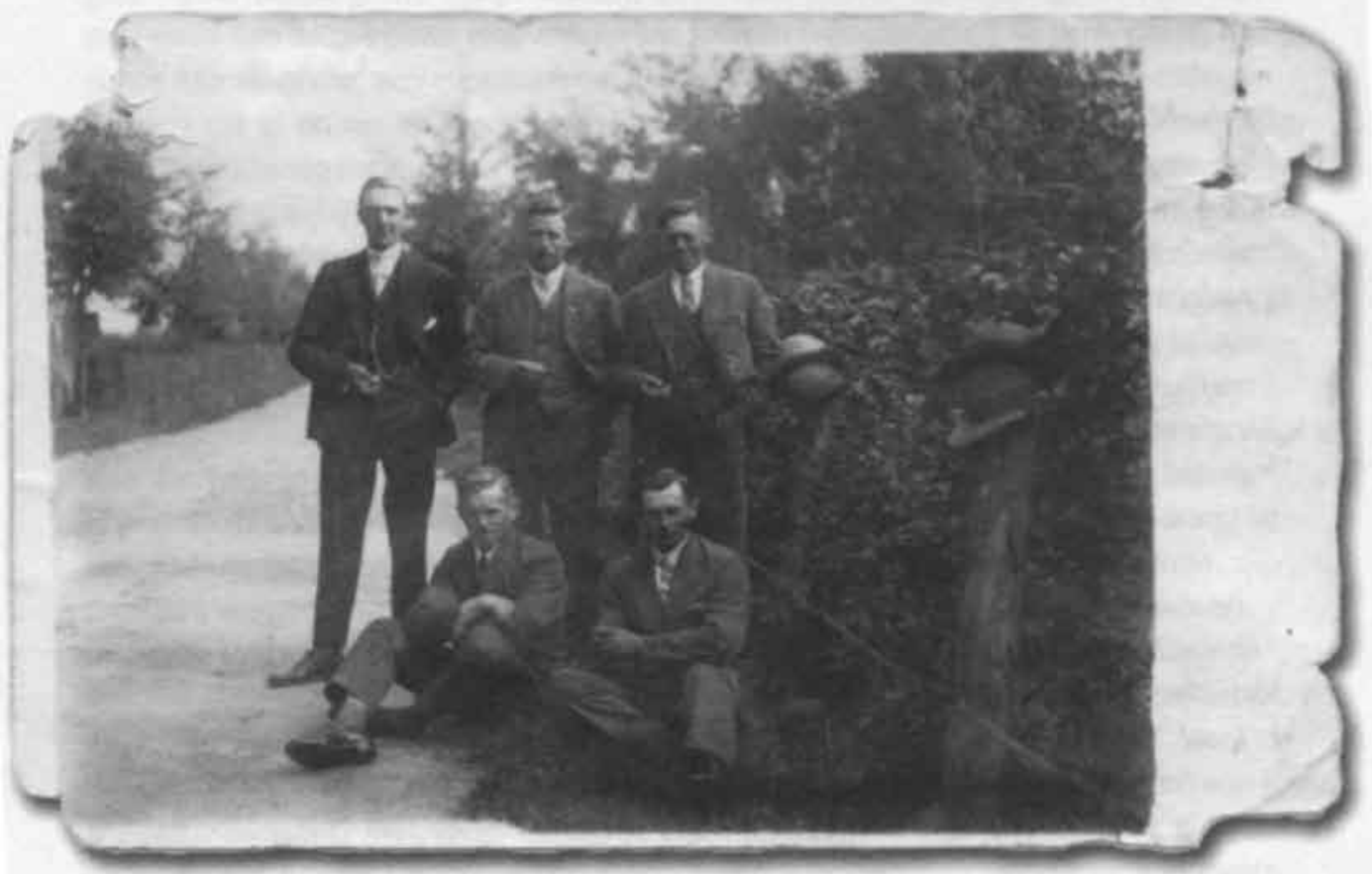

Jan Voorham in gezelschap van zijn studieclub. Als tuinder luisterde hij voor beslissingen over investeringen voor de informatie naar de landbouwvoorlichters, maar hij vormde zijn mening in discussie met zijn studieciub. 



\section{Voorwoord}

Op de foto staan vijf mannen in pak, enigszins stijf poserend voor de fotograaf. De staande man aan de rechter kant is mijn vader Jan Voorham (1902-1968). Hij had een tuindersbedrijf en teelde overwegend groente. In het begin was dat nog onder 'plat glas' op de 'koude grond' (geen kassen, en kassen zonder verwarming). In 1968 was de gehele tuin volgebouwd met verwarmde kassen (warenhuizen). Ik denk dat hij hier op de foto staat met zijn zogenaamde 'studieclub'. Dat was een groepje van collegatuinders die af en toe op zondag bij elkaar op het bedrijf kwamen kijken. Ze liepen dan, met een dikke sigaar in de hand, de tuin op en bespraken allerlei kwesties zoals de keuze van bestrijdingsmiddelen, de keuze van het gewas, de teeltmethodes, en het al dan niet investeren in nieuwe apparatuur of opbouw. Voor mijn vader was dat contact niet alleen leuk maar ook heel nuttig. Op die manier kon hij de snelle ontwikkelingen in de tuinbouw beter op hun waarde schatten. In diezelfde periode kwamen ook talloze vertegenwoordigers langs op de tuin die hun producten wilden verkopen. Zij hadden een voorlichtende rol over de nieuwe producten van het bedrif dat ze vertegenwoordigden. De vertegenwoordigers waren voor de praktijk van de glastuinbouw van belang omdat de meeste bestellingen via hen liepen. Van hen ging altijd een zekere drang uit om méér de gaan investeren. De innovaties in de tuinbouw moesten aan de man gebracht worden. Mijn vader hield tegenover hen altijd een flinke dosis wantrouwen. Naast de vertegenwoordigers kwamen er van het Landbouwschap ook zogenaamde landbouwvoorlichters langs. Zij gaven gevraagd en ongevraagd advies over teeltkeuze, en vooral over noodzakelijke investeringen om het bedrijf rendabel te houden. Moet er wel of niet verwarming worden aangelegd? Moet er een nieuw en hoger warenhuis worden neergezet? Mijn vader behoorde zoals elke zelfstandige tuinder in die tijd tot de doelgroep van de landbouwvoorlichting. Het landbouwschap stond voor een zware taak. Duizenden individuele tuinders moesten jaar in jaar uit individuele moeilijke beslissingen nemen over investeringen, meestal met als gevolg een nog grotere schuld bij de bank. Het grootste deel van de tuinders was geen ondernemer in hart en ziel. Om hen te motiveren tot innovatie was er een intensieve persoonlijke benadering noodzakelijk. Onder andere door de succesvolle structuur van de landbouwvoorlichting, met de landbouwvoorlichters en de actieve ondersteuning van de studieclubs, kon de Nederlandse tuinbouw internationaal een grote vlucht nemen. In Nederland is door die ervaringen van de landbouwvoorlichting bij de Landbouwhogeschool in Wageningen de voorlichtingskunde als wetenschappelijke discipline ontstaan. De landbouwvoorlichters waren onafhankelijker dan de vertegenwoordigers van commerciële bedrijven, maar ook van hen ging een zekere drang tot investeren uit. Dat was ook heel logisch want een tuinder moest met zijn tijd meegaan. Er werden in die periode erg veel innovaties ontwikkeld. Tuinders moesten investeren om vroeg genoeg in het jaar voldoende kwaliteit en kwantiteit in opbrengst te behalen. Mijn vader hechte veel belang aan de mening van de landbouwvoorlichter, maar 'de voorlichter had makkelijk praten' want hij was ten slotte zelf geen tuinder. Mijn vader hechtte het meeste belang aan het oordeel van zijn studieclub. Zij waren zoals hij en zaten in hetzelfde schuitje. Hij vertrouwde hun oordeel 
het meest. Mijn vader volgde hier een principe dat de werkzaamheid van de voor-endoor methode verklaart: je luistert naar een expert voor de informatie, maar je vormt je mening na discussie met je gelijken. Het is jammer dat ik nooit de gelegenheid heb gehad om daarover met mijn vader van gedachten te wisselen.

Dit proefschrift is ontstaan in de marge van mijn werk voor de GGD Rotterdam, en beslaat een periode van meer dan 10 jaar werk bij de GGD. De missie van de GGD is 'het beschermen en bevorderen van de kwaliteit van de gezondheid van de Rotterdamse bevolking door te zorgen voor goede maatschappelijke gezondheidszorg en door bij te dragen aan de kwaliteit van woon -, werk -, en leefomgeving als basis voor de volksgezondheid' (GGD21, de strategische beleidsvisie van de GGD Rotterdam, 1999). Het uitvoeren van evaluatieonderzoek is een noodzakelijke stap in de ontwikkeling en implementatie van effectieve interventie op het gebied van gezondheidsbevordering. De GGD van Rotterdam kan daarbij als een academische werkplaats voor de maatschappelijke gezondheidszorg een belangrijke rol vervullen. Dat heeft Ferd Sturmans in zijn inaugurele rede bepleit en later in een overeenkomst met het Medisch Centrum Erasmus vastgelegd. Het is van belang dat juist op het gebied van de gedragsgerichte preventie veel aandacht is voor evaluatieonderzoek omdat er bij gezondheidsvoorlichting weinig automatische feedback over de effectiviteit van de interventies is. Evaluatieonderzoek is een noodzakelijke 'vinger aan de pols' voor de effectiviteit van gezondheidsvoorlichting. Maar evaluatieonderzoek is geen hoofdtaak, en is slechts een onderdeel van 'het zorgen voor een goede maatschappelijke gezondheidszorg'. Het meeste werk in dat proces is niet het uitvoeren van het evaluatieonderzoek en het schrijven van de artikelen daarover. Het meeste werk is het (doen) ontwikkelen en (doen) uitvoeren van de interventies ter bevordering van de gezondheid van de inwoners van Rotterdam.

Ferd Sturmans en Gerjo Kok hebben mij als promotores gestimuleerd om de artikelen die over de interventieprojecten zijn geschreven in een proefschrift te bundelen. Ik hoop dat het ideaal van Ferd Sturmans over de GGD als academische werkplaats een stap dichterbij is gekomen.

Het meeste werk - van mijzelf, maar vooral ook van anderen! - is in dit proefschrift relatief weinig zichtbaar. Daarom wil ik alle betrokkenen bij de drie interventieprojecten in dit proefschrift bedanken. Zonder de enthousiaste inbreng van de seniorenvoorlichters, de migrantenvoorlichters en migrantenvoorlichtsters, de steunpunten voor de seniorenvoorlichting en de migrantenvoorlichting zouden de interventies niet mogelijk zijn geweest. Ik zou graag iedereen persoonlijk bedanken maar dat zou een lange lijst namen vergen.

1) Sturmans $F$ (1998) Van wederzijds belang. Over nut en noodzaak van academisering van de maatschappelijke gezondheidszorg. Inaugurele rede bij de aanvaarding van het ambt van bijzonder hoogleraar

Epidemiologie en Gezondheidsbeleid van de Erasmus Universiteit, 18 juni 1998. 
Zonder iemand te kort te doen, wil ik enkele uitzonderingen maken. Paul Kocken is mijn directe collega met wie ik twee van de drie projecten heb mogen uitvoeren. Zljn nauwgezette en gedegen wetenschappelijke inbreng is voor mij van groot belang geweest. Daarnaast hebben op de afdeling Ontwikkeling \& Implementatie (sector Gezondheidsbevordering) van de GGD veel mensen een stimulerende rol gehad in de afronding van dit proefschrift. Onder andere in het zogenaamde voor-en-door-overleg (Yvonne van den Berg. Marja van den Berg, Tine de Hoop, Nelleke Huiskamp, Marjan Kok) vonden stimulerende discussies plaats waarbij de confrontatie tussen de theorie en de praktijk vaak tot nieuwe ideeën leidde. Voor de secretariële ondersteuning wil ik Peter Schols en Anja Wijgers bedanken. Tenslotte wil ik Fiep, Lotte en Guus bedanken voor hun begrip en geduld vanwege de tijd die ik niet samen met hen, maar aan dit proefschrift heb besteed.

Ik wil in dit voorwoord één persoon gedenken: Perihan Ozkan - Buşdayci. Perihan is veel te jong overleden. Ze heeft een belangrijke bijdrage geleverd aan de ontwikkeling van de functie van de allochtone zorgconsulent. In die rol staat Perihan op de omslag van dit proefschrift.

Toon Voorham 


\section{Inhoudsopgave}

$\begin{array}{lr}\text { Voorwoord } & 7 \\ \text { Inhoudsopgave } & 11 \\ \text { Originele artikelen } & 14 \\ \text { Financiële steun } & 14\end{array}$

1. Theoretische onderbouwing van de voor-en-door methode in de gezondheidsbevordering

$\begin{array}{ll}\text { 1.1. Inleiding } & 18\end{array}$

1.2. De gouden driehoek $\quad 19$

1.3. Werving, selectie en opleiding 20

1.4. Begripsbepaling: voorlichtingskundig $\quad 21$

1.5. Vormen van peer voorlichting $\quad 22$

1.6. Dimensies van voor-en-door voorlichting: het peerschap 23

$\begin{array}{ll}\text { 1.7. De theoretische onderbouwing van peer voorlichting } & 27\end{array}$

$\begin{array}{ll}\text { 1.7.1. De sociale leertheorie } & 27\end{array}$

1.7.2. De sociale vergelijkingstheorie $\quad 29$

1.7.3. De diffusie van innovatietheorie $\quad 30$

1.7.4. Het persuation-communication model 32

1.7.5. Wijkgerichte en gemeenschapsgerichte strategieën $\begin{array}{ll}\text { ('community interventions') } & 33\end{array}$

1.7.6. Samenvatting van de theoretische onderbouwing 36

1.7.7. De ideale peer voorlichter $\quad 36$

$\begin{array}{ll}\text { 1.8. Probleemstelling } & 37\end{array}$

$\begin{array}{ll}\text { 1.8.1. Een practische strategie } & 37\end{array}$

$\begin{array}{ll}\text { 1.8.2. Drie projecten } & 39\end{array}$

$\begin{array}{ll}\text { Literatuur } & 42\end{array}$

2. Effect of a peer-led senior health education program $\quad 47$

$\begin{array}{ll}\text { Abstract } & 48\end{array}$

$\begin{array}{ll}\text { 2.1. Introduction } & 49\end{array}$

2.2. Outline of the course "Successful Aging" 50

2.2.1. Course contents $\quad 50$

2.2.2. Behavioural model 50

2.2.3. Course strategies $\quad 51$

2.3. Method $\quad 52$

2.3.1. Measures $\quad 52$

2.3.2. Analysis 53

2.4. Results 53

2.4.1. Response 53

2.4.2. Effectiveness $\quad 54$

2.5. Discussion 55

References $\quad 58$ 
3. Kenmerken van de voorlichter bij het effect van seniorenvoorlichting 61 Samenvatting

3.1. Inleiding

3.2. Theoretische basis van de voor-en-door strategie 63

$\begin{array}{lll}\text { 3.3. Probleemstelling } & 64\end{array}$

3.4. Opzet van het onderzoek: De cursus 'Succesvol ouder worden'. 65

3.5. Variabelen 66

$\begin{array}{ll}\text { 3.6. Analyse } & 67\end{array}$

$\begin{array}{ll}\text { 3.7. Resultaten } & 67\end{array}$

$\begin{array}{ll}\text { 3.8. Conclusie } & 70\end{array}$

$\begin{array}{ll}\text { Literatuur } & 72\end{array}$

4. Effects of peer-led AIDS education aimed at Turkish and Moroccan $\quad 75$ male immigrants in the Netherlands

$\begin{array}{ll}\text { Summary } & 76\end{array}$

$\begin{array}{ll}\text { 4.1. Introduction } & 77\end{array}$

4.2. The aids education session $\quad 78$

$\begin{array}{ll}\text { 4.3. Method } & 79\end{array}$

4.3.1. Measures $\quad 80$

4.3.2. Analysis $\quad 80$

4.4. Results $\quad 81$

$\begin{array}{ll}\text { 4.4.1. Respons } & 81\end{array}$

$\begin{array}{ll}\text { 4.4.2, Effects } & 81\end{array}$

4.5. Conclusion and discussion $\quad 84$

$\begin{array}{ll}\text { References } & 87\end{array}$

5. Opvattingen over voorlichting en de voorlichter in de eigen taal bij Turkse en Marokkaanse mannen na voorlichting over aids. $\quad \mathbf{8 9}$

$\begin{array}{ll}\text { Summary } & 90\end{array}$

5.1. Inleiding $\quad 91$

5.2. Methode: praktijk van de Aidsvoorlichting $\quad 92$

$\begin{array}{ll}\text { 5.3. Resultaten } & 94\end{array}$

5.4. Discussie 95

$\begin{array}{ll}\text { Literatuur } & 97\end{array}$

6. Effectiveness of diabetes peer education for migrant type $\mathbf{2}$ diabetes patients on glycaemic control: a controlled experiment in general practice. 99 $\begin{array}{ll}\text { Abstract } & 100\end{array}$

$\begin{array}{ll}\text { 6.1. Introduction } & 101\end{array}$

6.2. Patients and method $\quad 101$

$\begin{array}{lr}\text { 6.3. Intervention } & 102\end{array}$

6.4. Outcome measures 103

$\begin{array}{lr}\text { 6.5. Statistical analysis. } & 103\end{array}$ 
6.6. Results

6.7. Discussion

7. Het effect van voorlichting in de eigen taal aan Turkse diabetespatiënten

7.1. Inleiding

7.2. Omschrijving van de interventie

7.3. Onderzoekspopulatie

7.4. Methode

7.5. Analyse

7.6. Resultaten

7.7. Discussie

Literatuur

8. De effectiviteit van diversiteit in gezondheidsbevordering

8.2. Drie projecten

8.3. Interventietheorie bij gezondheidsbevordering

8.3.1. Project 1: Succesvol ouder worden

8.3.2. Project 2: Aidsvoorlichting aan Turkse en Marokkaanse mannen

8.3.3. Project 3: Diabetesvoorlichting voor Turken

8.3.4. Resultaten van de drie projecten

8.4. Implicaties voor onderzoek

8.4.1. Objectief en subjectief peerschap

8.4.2. Emancipatorisch effect

8.4.3. Effectiviteit en toegevoegde waarde. 


\section{Originele artikelen}

\section{Project 1:}

Hoofdstuk 2: Kocken, P.L., Voorham, A.J.J. (1998). Effects of a peer-led senior health education program. Patient Education and Counselling; 34 , 16-23.

Hoofdstuk 3: Voorham A.J.J., Kocken P.L. (2000) Kenmerken van de voorlichter bij het effect van seniorenvoorlichting: een kwantitatieve procesevaluatie. TSG/ Tijdschrift voor gezondheidswetenschappen; 78, 5: 303-308.

\section{Project 2:}

Hoofdstuk 4: $\quad$ Kocken P.L., Voorham A.J.J., Brandsma J., Swart W.A.J.M. (2001) Effects of peer-led Aids education aimed at Turkish and Moroccan male migrants in the Netherlands: a randomized controlled evaluation study. European Journal of Public health; 11, 2: 153-159.

Hoofdstuk 5: Voorham A.J.J., Kocken P.L., Brandsma J., van Haastrecht P. (2002) Opvattingen over voorlichting en de voorlichter in de eigen taal bij Turkse en Marokkaanse mannen na voorlichting over Aids. TSG/ Tijdschrift voor gezondheidswetenschappen; 80, 2: 110-114.

\section{Project 3:}

Hoofdstuk 6: $\quad$ Uitewaal P.J.M., Voorham A.J.J., Bruijnzeels M., Berghout A., Hoes A.W., Bernsen R.M.D., Trienekens P.H., Thomas S., Sturmans F. Ethnic-specific diabetes education for Turkish type 2 diabetics: a controlled study in general practice. (submitted).

Hoofdstuk 7: Voorham A.J.J., Uitewaal P.J.M., Bruijnzeels M. (2002) Het effect van voorlichting in de eigen taal aan Turkse diabetespatiënten een experiment in de eerste lijn. TSG/ Tijdschrift voor gezondheidswetenschappen; 80, 8: 514-520.

\section{Financiële steun}

Project 1 is uitgevoerd met financiële steun van de Commissie Determinanten van Gezondheid van het Ministerie van Volksgezondheid, Welzijn en Sport. Project 2 kreeg financiële steun van het Programma Coördinatiecommissie Aids-onderzoek van het Aidsfonds. Project 3 werd financieel gesteund door de Commissie Sociaal-economische gezondheidsverschillen, tweede fase van het Ministerie voor Volksgezondheid, Welzijn en Sport (Commissie Albeda). 


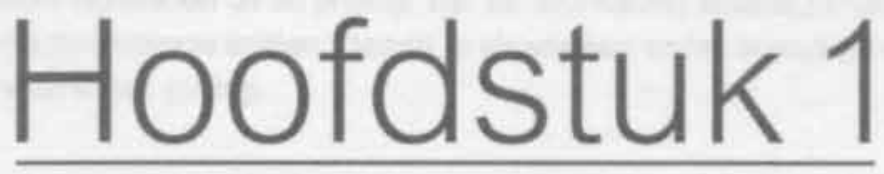

Theoretische onderbouwing van de voor-en-door methode in gezondheidsbevordering 


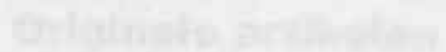

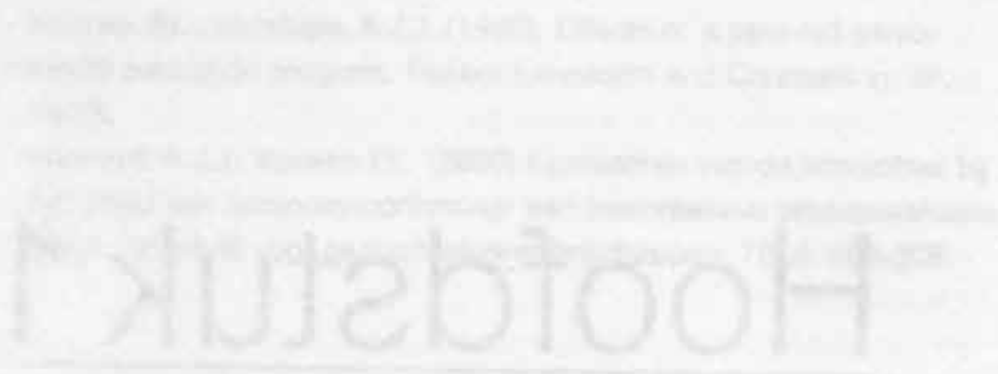

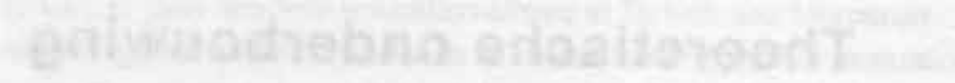

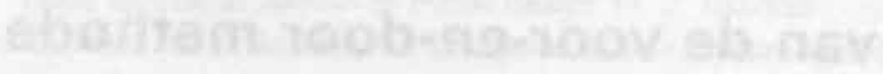

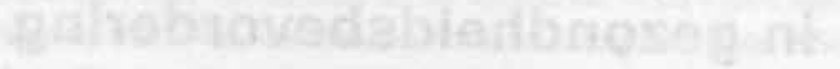




\section{Theoretische onderbouwing van de voor-en-door methode in gezondheidsbevordering}

In dit hoofdstuk wordt de plaats van voor-en-door methode in gezondheidsbevordering beschreven. Op basis van een rondgang langs de verschillende vormen, een beschrijving van de theoretische fundering en de praktische inbedding in gezondheidsbevordering worden een aantal voorwaarden van de werkzaamheid onderzocht. Allereerst volgen enkele voorvallen uit de praktijk van de voorlichting waarbij problemen en vragen rond de methode spelen. Daarbij is steeds een ander aspect van de voor-endoor methode in het geding.

\section{Mehmed}

Mehmed is een Turkse migrantenvoorlichter bij de GGD Rotterdam. Hij ziet er in zijn pak meestal onberispelijk uit, en is erg actief in het bereiken van de Turkse mannen met aids-voorlichting in de koffiehuizen. Als hij in een koffiehuis komt waar veel oudere Turkse mannen komen, dan voelt hij zich toch enigszins belemmerd om daar het onderwerp Aids ter sprake te brengen. De mannen in het koffiehuis zouden zijn vader kunnen zijn! In het begin wist hij niet goed hoe hij veel aansluiting zou kunnen vinden. Zou het niet beter zijn geweest als er ook een oudere Turkse man als voorlichter was opgeleid? Dat die mannen zijn vader hadden kunnen zijn, is precies wat hij in zijn voorlichting als uitgangspunt is gaan nemen: 'Wij, Turkse jongeren, moeten er toch voor zorgen dat we geen onnodige risico's lopen'. Hij speelt dan de rol van de wat oudere voorbeeldige zoon die kan uitleggen wat de jongeren moeten weten en doen, en dus wat de Turkse mannen als ouders moeten vinden.

\section{Semiha}

Semiha geeft in de huisartspraktijk voorlichting onder andere over diabetes aan Turkse mannen en vrouwen. $\mathrm{Zij}$ is vergeleken met deze doelgroep Turkse diabetespatiënten relatief jong, en heeft dus hetzelfde probleem als Mehmed. Ze meet zich de rol van dochter aan. Bovendien heeft Semiha nog een ander 'nadeel': ze is zelf geen diabetespatiënt, en ze kan dus niet als diabeteslotgenoot met haar patiënten omgaan, maar alleen als migrantlotgenoot. Ze kan wel lotgenotencontact organiseren door de patiënten bij elkaar te brengen, en ze kan de ervaring van andere patiënten met haar eigen patiênten delen.

\section{Mijn huisarts}

Mijn huisarts is bijna met pensioen. De laatste keer dat ik bij hem was, had ik last van een gewricht in mijn vinger. Ik kon het niet meer buigen zonder pijn, en ik was bang voor iets ernstigs. Hij legde me uit wat het waarschijnlijk was: een stukje kapsel dat los was geraakt. Het zou vanzelf langzaam over gaan. En zo zei 
hij 'Wij, mannen van zekere leeftijd krijgen vaker van dit soort kleinere klachten.... Dat laatste had hij niet moeten doen: Dat Wij sloeg nergens op, hij was zeker 15 jaar ouder dan ik!

\section{Ouafa}

Ouafa is Marokkaanse voorlichtster maar heeft een hele tijd haar werk niet goed kunnen doen omdat de mensen met wie ze samenwerkte haar niet meer konden vertrouwen. Haar doelgroep, de Marokkaanse vrouwen met wie ze groepsvoorlichting organiseerde, mochten een tijd lang geen contact met haar hebben. Niet omdat Ouafa zelf iets had gedaan, maar haar man was politiek actief, en had in de ogen van veel Marokkaanse mannen iets gedaan wat niet geaccepteerd kon worden. De achternaam van Ouafa was besmet.

Als het om veranderen van gedrag gaat laten de meeste mensen zich het gemakkelijkst motiveren door mensen die dicht bij hen staan zoals naasten, vrienden of kennissen. Die naasten, vrienden of kennissen zouden in theorie de beste peer voorlichters voor dat individu kunnen zijn. In de praktijk van de gezondheidsvoorlichting met grote en verschillende doelgroepen is het onmogelijk om steeds de 'allerbeste' peer voorlichter voor een specifieke situatie of voor een specifiek gezondheidsprobleem beschikbaar te hebben. Dat zou veel investeringen vergen, en het zou de uitvoering van gezondheidsbe-vordering weinig flexibel maken. Het is wel mogelijk om op een andere manier aan de randvoorwaarden voor effectiviteit te voldoen door een bepaald gedrag van de peer voorlichter of door als peer een bepaalde rol aan te nemen. Echter, dat kan zoals bij de huisarts hierboven ook verkeerd aflopen. Ook kunnen er onbekende factoren in het spel zijn die de peer voor de doelgroep een tijd lang onacceptabel maken, zoals het laatste voorbeeld laat zien.

\subsection{Inleiding}

Van 1769 tot 1988 (sicl) bestond in Rotterdam een gezelschap van Rotterdamse notabelen, het zogenaamde Bataafsch Genootschap, dat tot doel had de wetenschappelijke inzichten te verspreiden. Ofwel, zoals het bij de oprichting werd genoemd: 'ter bevordering en de volmaking van de proefondervindelijke wijsbegeerte' (van Lieburg en Snelders, 1989). Van Lieburg beschrijt hoe de arts Johannes Bicker, als lid en oprichter van dit Genootschap, onder de plattelandsbevolking rondom Rotterdam voorschriften verspreidde in de boerse letter (en ongetwijfeld ook in een boerse taal) om haar vertrouwd te maken met de geëigende leefregel voor het wonen in de polders' (citaat uit van Lieburg, 1989). Daarom kan Bicker voor Rotterdam de grondlegger van de gezondheidsvoorlichting worden genoemd. En het model van de voorlichting is ook duidelijk: de arts als expert geeft de onwetende patiënt instructies hoe te handelen. Het Bataafse Genootschap stond als gezelschap van de notabelen van de stad, die als nieuwe hygiënisten het beste voor hadden met hun patiënten, erg ver weg van de doelgroep. Toch heeft Bicker, met het voorstel om de voorlichting in 'de boerse letter' te doen, voor 
ogen gehad om de doelgroep zo effectief mogelijk met gezondheidsinformatie te bereiken. Hij is daarmee als eerste in Rotterdam bezig geweest met 'voorlichting in de eigen taal en cultuur'.

Het denken over het effectief bereiken van doelgroepen in de stad is nog steeds de motor achter het ontstaan van nieuwe vormen van intensieve gezondheidsvoorlichting. waaronder peer voorlichting. Bij de GGD van Rotterdam e.o. zijn voorlichtingsprojecten ontstaan met homomannen, met Turkse, Marokkaanse, Kaapverdiaanse, Chinese, Antilliaanse en Surinaamse vrouwen, met Turkse, Marokkaanse, Surinaamse, Antilliaanse, Kaapverdiaanse mannen, en met seniorenvoorlichters. Bij de GGD is men deze vorm van voorlichting voor-en-door voorlichting gaan noemen om kernachtig aan te geven waar het om gaat en om alle vormen onder één noemer te kunnen brengen. Is dat wel terecht? Kunnen de migrantenmannen wel vergeleken worden met homomannen met betrekking tot hun voorlichtingswerk? In dit artikel wordt een theoretische basis geschetst van deze vormen van gezondheidsvoorlichting. Daarmee worden ook de grenzen zichtbaar van de methode: waar eindigt het peermodel en waar begint bijvoorbeeld het expertmodel. Wat zijn factoren die de effectiviteit bevorderen of belemmeren? In dit proefschrift worden drie Rotterdamse projecten besproken waarbij gebruik is gemaakt van deze voor-en-door methode, en waarbij evaluatieonderzoek heeft plaatsgevonden:

- Voorlichting over 'Succesvol ouder worden' voor en door senioren,

- Voorlichting over Aids voor en door Turkse en Marokkaanse mannen,

- Voorlichting over diabetes aan Turkse diabetespatiënten door een Turkse voorlichtster.

\subsection{De gouden driehoek}

In de praktijk van de voorlichting bij een GGD van een grote stad als Rotterdam, is de voor-en-door voorlichting een belangrijk onderdeel van een grotere voorlichtingsstructuur. Die structuur is omschreven als de 'Gouden Driehoek van Gezondheidsbevordering' (Voorham \& Van Haastrecht, 1996). Om de moeilijker te bereiken doelgroepen (o.a. migranten) goed te bereiken met gezondheidsvoorlichting, is er een 'gouden driehoek' nodig van:

- Uitvoerende voor-en-door voorlichters (of peer voorlichters), en ondersteuning van deze voorlichters met materiaal, scholing, deskundigheid en steun,

- Decentrale, wijkgerichte centra waar de voorlichters kunnen worden ingezet, zoals gezondheidscentra, wijkcentra, koffiehuizen, etc.

- Planmatige aansturing, vanuit een analyse van het gezondheidsprobleem tot aan de aangetoonde effectiviteit van de inzet.

In termen van functies en mensen zijn er steunpuntfunctionarissen die de voorlichters ondersteunen met deskundigheid, scholing, voorlichtingsmateriaal, etc. Er zijn GVOfunctionarissen die de inhoud van de voorlichting bepalen bijvoorbeeld in het kader van wijkgericht werken, of op basis van stedelijk epidemiologisch en/of gedragsgericht onderzoek (Zie ook Kocken, 2000). En er zijn decentrale centra nodig, zo dicht mogelijk bij de einddoelgroep, die meewerken aan de uitvoering van specifieke trajecten, en de 
peer voorlichter ter plekke kunnen ondersteunen. Meestal gaat het niet uitsluitend om gedragsgerichte interventies. Denk aan de inzet in een gezondheidscentrum waarbij de peer voorlichter ook helpt bij de taal. In die situaties heeft de peer voorlichter vaak een 'intermediaire' rol: hij of zij vormt op meer vlakken de brug tussen de doelgroep en de professional.

\subsection{Werving, selectie en opleiding}

Voor de selectie van de peer voorlichters geldt over het algemeen: zo specifiek als mogelijk maar zo algemeen als onvermijdelijk. Het beste is zo veel mogelijk gelijkheid met de doelgroep na te streven, maar die doelgroep moet groot genoeg blijven, zodat er continuiteit en flexibiliteit in het aanbod is. Ook de doelgroep verandert voortdurend. Elke peer voorlichter vervult een brugfunctie tussen de doelgroep en de voorlichtende instantie. En hij of zij moet beide posities kunnen begrijpen en invoelen, en voor de ander kunnen verwoorden. Dat vraagt inlevingsvermogen, maar ook begrip van de voorlichtingsprocessen. Hij of zij moet zich kunnen inleven in zo'n groot mogelijk deel van de doelgroep, maar óók in de 'opdrachtgevers'. De peer voorlichter moet in staat zijn om zijn eigen rol in het proces van de voorlichting te plaatsen en te begrijpen, enigszins afhankelijk van de mate van zelfstandigheid die wordt verwacht. Behalve betrokkenheid bij de doelgroep wordt meestal ook betrokkenheid bij het onderwerp gevraagd. Als de peer voorlichter bij het onderwerp van de voorlichting op geen enkele manier enige betrokkenheid heeft, of de relevantie voor de doelgroep moeilijk kan begrijpen, dan is er geen basis voor die voorlichting. In dat geval zal de motivatie om mee te werken aan de voorlichting relatief gering zijn. Als de voorlichter alléén vanwege geld kan worden ingezet dan is dat geen ideale randvoorwaarde voor effectiviteit. De combinatie van betrokkenheid bij de doelgroep, en betrokkenheid bij het onderwerp bepaalt voor een belangrijk de mate van peerschap.

\section{De kadercursus Gezondheidsvoorlichting voor Turkse en Marokkaanse vrouwen.}

Bij de migrantenvoorlichting zijn de selectiecriteria steeds in ontwikkeling geweest. Toen in Rotterdam in 1988 de eerste 'kadercursus migrantenvoorlichting' werd georganiseerd, stond vast dat er Turkse en Marokkaanse vrouwen geselecteerd zouden worden om de twee grootste groepen migrantenvrouwen te kunnen bedienen (NIGZ, 1998). De onderwerpen waren 'vrouwenzaken' zoals zwangerschap en bevalling, opvoedingsondersteuning, vrouwenklachten, en dergelijke. Bij de selectie voor de kadercursus gold dat de cursist de cursus in het Nederlands moest kunnen volgen, en kunnen begrijpen. En men moest de tijd en gelegenheid hebben want het betrof een intensieve langdurige cursus (twee jaar lang, één dag per weekl). Er gold geen formele vooropleidingseis. De manier waarop werd geworven, namelijk via de zelforganisaties en de hulpverleningsinstellingen (o.a. via de Stichting Buitenlandse Werknemers Rijnmond, een regionaal centrum voor buitenlanders), garandeerde wel een zekere betrokkenheid bij de verschillende gemeenschappen. Bij de Marokkaanse kandidaten werd bovendien nog gelet op het beheersen van de Berberse taal, het belangrijkste Marokkaanse dialect in 
Rotterdam. Hoewel de keuze niet erg groot was, zijn er wel discussies geweest over de leeftijd en de mate van moderniteit. Er is een zekere verdeling naar leeftijd nagestreefd over de eerste cursisten. In de loop van de tijd zijn deze selectiecriteria steeds in discussie geweest, zoals naar aanleiding van de voorlichtster die in de ogen van velen té modern (lees: té sexy) gekleed was. Intussen zijn er in Rotterdam drie kadercursussen uitgevoerd. In de laatste cursus is het accent sterk komen liggen op de groeiende inzet van de migrantenvoorlichtsters in de eerste lijn. De vierde cursus die op dit moment loopt (anno 2003) wordt verzorgd door het ROC Albeda op MBO-3-niveau. Dat is een belangrijke stap in de richting van opname van de cursus in het regulier onderwijs.

\section{Voorlichting in de eigen taal en cultuur over Aids}

Op het moment dat het noodzakelijk werd dat Turkse en Marokkaanse mannen over aids werden voorgelicht, werden daarvoor apart Turkse en Marokkaanse mannen opgeleid. Ook daarbij is de werving vooral via zelforganisaties, en mond-op-mond reclame verlopen. Op dat moment was het ondenkbaar dat een vrouwelijke voorlichtster een groep mannen zou voorlichten, zeker met het onderwerp Aids. In de individuele kontakten in de eerste lijn was het echter snel geaccepteerd dat een vrouwelijk voorlichtster ook mannelijke patiënten kreeg. En op dit moment, vijf jaar later, ontstaan er experimenten waarbij de migrantenvoorlichtsters met oudere groepen mannen het 'ouder worden' in Nederland bespreken. Bij de selectie van de mannen voor de aids-voorlichting gold in grote lijnen hetzelfde. De cursus was veel minder intensief omdat het startniveau van mannen over het algemeen veel hoger is dan bij de vrouwen. Hier was de beschikbare tijd soms een knelpunt omdat veel cursisten werkten. De cursist moest in staat zijn om zelfstandig koffiehuisvoorlichtingen te organiseren en uit te voeren.

\section{De kadercursus gezondheidsvoorlichting voor en door ouderen.}

Voor de eerste lichting seniorenvoorlichters werden ouderen geselecteerd die in staat waren om op hbo-niveau de kadercursus te volgen. De idee was dat de seniorenvoorlichter, behalve de uitvoering van de voorlichting, ook veel organisatiewerk zou doen zoals het werven en benaderen van instanties, het opsporen van voorlichtingsmateriaal, etc. (Vergelijk Kemme, 1995). De voorlichter moest behoorlijk zelfstandig en samen met de opdrachtgever een onderwerp kunnen uitwerken. In de uitvoering van de voorlichting in de groep moest de seniorenvoorlichter zich als procesbegeleider kunnen opstellen. Uiteindelijk bleek de veelheid van eisen in de praktijk te hoog gegrepen en is de ondersteuning uitgebreid, met name bij de voorbereiding van de bijeenkomsten. Er zijn bij de selectie voor de eerste cursus kandidaten afgevallen omdat ze relatief jong waren, maar ook omdat ze vermoedelijk niet in staat zouden zijn om een groep te begeleiden.

\subsection{Begripsbepaling: voorlichtingskundig}

Een Turkse migrantenvoorlichtster die een opleiding heeft gevolgd, een certificaat heeft gehaald, vervolgens in dienst is gekomen van een GGD of een gezondheidscentrum, is 
die nog steeds een 'peer' voor haar achterban? Ja, want ze doet in haar voorlichting een beroep op haar Turks-zijn en misschien op haar vrouw-zijn. Ze zal dus aspecten van de peer methode gebruiken. Elke uitvoerende voorlichter die in de uitvoering impliciet of expliciet - een beroep doet op een aspect van gelijkheid met de doelgroep past een peer methode toe, en is in die zin dus een peer voorlichter. Een organisatie die 'peers' inzet bij de uitvoering van gezondheidsvoorlichting past een peer methode toe die bij de ontwikkeling van de interventie is gekozen. Bartholomew e.a. (2001) beschrijven het proces van interventieontwikkeling ('intervention mapping') in vijf fasen: vaststellen van de proximale programmadoelen, het kiezen van de op theorie gebaseerde methodes en praktische strategieën, het maken van programma componenten en materialen, de planning van adoptie, implementatie en het onderhoud, en ten slotte de planning van de evaluatie. Een specifieke vorm van peer voorlichting (bijv. aids-voorlichting voor en door homomannen op de baan) is in deze termen een praktische strategie, gebaseerd op 'modelling' of 'model leren' als methode. Het onderscheid is, zoals de auteurs zelf ook aangeven, vaak moeilijk (zie p 172). Zo noemen zij het gebruik van 'role model stories' zowel een methode als een strategie. Peer voorlichting kan zowel als een methode als een strategie worden gezien afhankelijk van de mate waarin de methode in concrete activiteiten is vertaald. Peer voorlichting in het algemeen, in al zijn verschijningsvormen, kan het beste een methode worden genoemd. Hoe concreter de praktische vorm, hoe eerder er sprake is van strategie. Bijvoorbeeld Aids-voorlichting in een koffiehuis door een Turkse migrantenvoorlichter met gebruik van een condoomdemonstratie en ondersteund door een audiobandje, is een strategie. Belangrijk is te beseffen dat de methode - Dat is het effectieve elementl - niet wordt ondergesneeuwd of wordt belemmerd door de praktische strategie. In het proces van 'intervention mapping' moet de keuze voor peer voorlichting als methode in deze stap worden gemaakt bij de vertaling van de theoretische modellen in praktische strategieën. Daarbij is het noodzakelijk te weten wat de theoretische basis is van de peer methode. Want daarin moet het effectieve element worden gevonden: waarom werkt de peer methode?

\subsection{Vormen van peer voorlichting}

In de Angelsaksische literatuur wordt met de term 'peer education' vrijwel uitsluitend bedoeld het inschakelen van leerlingen op middelbare scholen bij de uitvoering van voorlichting of onderwijs, en dus ook bij de uitvoering van gezondheidsvoorlichting. (Zie Mellanby e.a., 2000; Frankham, 1998; Green, 2001). Mogelijk ligt de oorsprong in het kostschoolsysteem van Engeland. In de $18 \mathrm{e}$ en $19 \mathrm{e}$ eeuw was het op de kostscholen in Engeland heel gebruikelijk om 'peer teaching' toe te passen. De leerlingen hielpen bij het onderwijs in de lagere klassen. Het effect was dat die leerlingen in achting stegen, dat ze een ondersteunende rol aanleerden, en dat de leerstof sterk werd verinnerlijkt. Voor de school was het economisch voordelig, en tot op de dag van vandaag wordt het principe toegepast. (Tones, 1992). In Nederland wordt deze peer methode sporadisch gebruikt voor onderwijsdoeleinden. Een succesvol recent experiment betrof leerlingbegeleiding in het voortgezet onderwijs door Turkse en Marokkaanse studenten. De raad- 
gevingen van de studenten aan de brugklassers hadden een positief effect op het cognitieve en sociaal-emotionele vlak (Crul, 2001). Op het gebied van gezondheidsvoorlichting is er zeer veel Angelsaksiche literatuur over de peer methode in het onderwijs. Milburn (1995) geeft een kritische review van de peer methode met jonge mensen op het gebied van seksuele gezondheid. Zij concludeert dat de projectverslagen enthousiasme uitstralen, een grote 'feel good factor' hebben maar dat gedegen evaluatieonderzoek meestal ontbreekt. In Nederland zijn ook een aantal experimenten met gezondheidsvoorlichting met jongeren, gedeeltelijk ook in het onderwijs, maar het is uitzonderlijk (Dugardyn, 1996). In Nederland zijn voor andere doelgroepen dan scholieren veel vaker peer methodieken gebruikt. Door het Nederlands Instituut voor Zorg en Welzijn (NIZW) is een inventarisatie gemaakt van de meest voorkomende vormen van voor-en-door voorlichting in Nederland (Penninx \& Prinsen, 2000). Zij noemen projecten met wijkbewoners, moeders, boeren, homoseksuele mannen, patiënten en ouderen. In de Angelsaksische literatuur zouden al deze vormen van peer voorlichters waarschijnlijk worden aangeduid met 'lay health advisors' (LHA). Over deze terminologische verwarring schrijft Eng e.a. als ze het hele continuüm schetst van 'natural helping' tot 'paraprofessional helping' (Eng e.a., 1997). Voorbeelden van de termen die gebruikt worden in de gezondheidsbevordering en ziektepreventie, en die zij samenvat met de LHA benadering: community health advisors, community health workers, health aids, natural helpers, peer educators, etc. In navolging van Service definieert ze de LHA als 'an individual who is indigenous to her or his community and consents to be a link between community members and the service delivery sy'stem' (Service \& Salber, aangehaald in Eng e.a., 1997; Earp e.a.,1997). De projecten die besproken worden vertegenwoordigen het hele spectrum van het ondersteunen van lekenhulp tot de betaalde paraprofessionals die ondersteund en getraind worden voor specifieke voorlichtingsdoelstellingen van de gezondheidszorgorganisatie. Eng legt hier de nadruk op de variaties die voorkomen met betrekking tot de professionalisering. Maar er zijn veel meer variaties die van belang zijn. De inperking of afgrenzing die voor de onderhavige analyse wordt voorgesteld is dat het een methode moet zijn die min of meer planmatig wordt toegepast om een specifiek leer- of veranderdoel te bereiken. Er wordt dus geen aandacht besteed aan buurtgroepen, zelfhulpgroepen, vrouwengroepen, etc. die zonder professionele bemoeienis bestaan, maar ongetwijfeld een belangrijke bijdrage kunnen leveren aan gezondheid. De praktijk van de gezondheidsbevordering in Rotterdam met migrantenvoorlichting en met seniorenvoorlichting zal op het spectrum van 'natural helping to lay health advisors' erg dicht tegen de laatste categorie zitten.

\subsection{Dimensies van voor-en-door voorlichting: het peerschap}

Als alle vormen van gezondheidsvoorlichting worden bekeken waarbij een vertegenwoordiger van de doelgroep wordt ingeschakeld om de doelgroep beter te bereiken, dan kunnen de volgende aspecten worden beschreven:

- De similariteit: het kenmerk of de kenmerken van de persoon waarmee de gelijkheid met de doelgroep wordt geclaimd zoals etniciteit, migrant-zijn, de taal, de leef- 
tijd, een woonwijk, de sekse en/of seksuele voorkeur. Hierbij is belangrijk de mate waarin er sprake is van bondgenootschap, lotgenootschap of wij-gevoel door deze gemeenschappelijke factor. Voor de allochtonen in de stad is dat behalve het migrantzijn ook de gemeenschappelijke taal. Bij de patiënten in zelfhulpgroepen is dat lotsverbondenheid: vrouwen met een geamputeerde borst hebben vooral steun aan elkaar als het erom gaat te leren omgaan met deze verminking. Een wijkbewoner zal een andere wijkbewoner gemakkelijk kunnen aanspreken als het onderwerp een directe relatie heeft met een gemeenschappelijk belang, bijvoorbeeld in het kader van kinderveiligheid een gevaarlijk kruispunt ter discussie stellen.

- De context of de situatie van de voorlichting. In een asielzoekerscentrum (AZC) kan een Bosnische asielzoeker een peer zijn voor een vluchteling uit Somalië, als ze tenminste in het Engels met elkaar kunnen praten. Er is dan het gemeenschappelijke belang beiden in een AZC te zitten. Als de asielzoeker met een voorlopige verblijfsstatus is verhuisd naar de stad is dat peerschap al minder vanzelfsprekend. Er is dan méér keus en er zijn méér mogelijkheden om landgenoten te zien die ook asielzoeker zijn.

- Het onderwerp van de voorlichting. Straatbewoners zijn in het kader van Opzoomeren (i.e. beleid van de Gemeente Rotterdam om betrokkenheid van bewoners bij de eigen straat te stimuleren) gemakkelijker een peer voor elkaar als het onderwerp de inrichting van de straat betreft. Het gemeenschappelijk belang creëert het peerschap. Het onderwerp Aids kan door een Turkse vrouwelijke voorlichtster niet met mannen worden besproken, en dus werd er voor mannen een specifiek traject ontwikkeld. Het taboe op het onderwerp staat in dit geval peerschap in de weg.

- Het doe/ van de voorlichting. Een doel waarbij een groot beroep wordt gedaan op inhoudelijke expertise is voor de 'peer' minder geschikt, terwijl een zekere expertise een belangrijke randvoorwaarde is. Over het algemeen is de peer voorlichter bij uitstek geschikt voor overredende of motiverende voorlichting op basis van gedeelde ervaring met de doelgroep. En vaak worden aan peer voorlichting doelstellingen gekoppeld die met 'empowerment' en emancipatie samenhangen.

- De professionaliteit van de peer. De mate waarin er sprake is van scholing om de functie uit te oefenen. Daarin zijn grote verschillen: van enkele trainingsbijeenkomsten tot een uitvoerige scholing. Er zijn dan ook grote verschillen in de professionaliteit van de voorlichters, als het gaat om inhoudelijke kennis maar ook als het gaat om voorlichtingsvaardigheden. De mate van professionaliteit van de peer is een belangrijke strategische keuze voor de voorlichtende organsatie. Daarmee hangt samen de keuze om de voorlichter wel of niet te betalen voor de voorlichtingsactiviteiten, en de keuze wel of geen arbeidscontract aan te bieden.

- De zelfstandigheid van de voorlichter. De Turkse en Marokkaanse aidsvoorlichters zijn opgeleid voor een relatief specialistische taak: ze geven voorlichting in verschillende settings, maar (bij de start van het project) alleen over Aids. In de werving van de locaties werken ze zeer zelfstandig, dat wil zeggen zelfstandiger dan de vrouwelijke voorlichtsters die aan de GGD verbonden zijn. De eerste lichting seniorenvoor- 
lichters in Rotterdam is geschoold op hbo-niveau. Van de seniorenvoorlichters werd verwacht dat ze een verzoek om voorlichting van 'analyse tot en met de uitvoering' min of meer zelfstandig konden vormgeven (Kemme, 1992). In de praktijk van de uitvoering bleken de seniorenvoorlichters nog veel ondersteuning en begeleiding nodig te hebben, maar in het begin was er een groot verschil met de andere voorlichters met betrekking tot de mate van zelfstandigheid.

- Het gedrag in relatie tot de rol van de voorlichter. De voorlichter kan expliciet een beroep doen op zijn overeenkomst met de doelgroep. Een Turkse voorlichter kan in zijn verhaal expliciet spreken over 'Wij, Turken in Rotterdam....', om daarmee meer aansluiting te vinden. Het beeld van de voorlichter bij de deeinemers kan ook beïnvioed worden door bijvoorbeeld het wel of niet roken van de voorlichter, door kleding. door zijn manier van praten, dus door meer algemene gedragskenmerken.

- Het gedrag in relatie tot het onderwerp van de voorlichting. Het is voor de aidsvoorlichter een keuze of hij bij een bepaalde doelgroep wel of geen condoomdemonstratie op een dildo geeft.

- De verwachtingen van de doelgroep met betrekking tot de rol van de voorlichter. De voorlichter tracht te voldoen aan de verwachtingen van de doelgroep. De doelgroep kan verwachtingen hebben met betrekking tot de deskundigheid van de voorlichter. Voorlichtsters die nog weinig ervaring hebben voelen zich vaak uitgetest met betrekking tot hun kennis. En het uittesten kan ook betrekking hebben op de similariteit. Bijvoorbeeld, de voorlichtster die vrouwen begeleidt met psychosomatische klachten, wordt door de vrouwen gevraagd of zij zelf niet af en toe hoofdpijn heeft met twee kinderen, een man een huishouden. Op dat moment kan de voorlichtster het wijgevoel versterken door over haar eigen ervaring te praten.

- De vorm van de voorlichting. Groepsvoorlichting, individuele voorlichting, voorlichting in het koffiehuis, manifestatiewerk, theater: de vorm kan het peerschap versterken of verzwakken. Elke doelgroep heeft andere passende vormen: Kaapverdianen in Rotterdam kunnen niet of moeilijk bereikt worden met formele groepsvoorlichting maar dat geldt bijvoorbeeld niet voor Turkse vrouwen die juist heel goed in groepen bereikt kunnen worden. De vorm van de voorlichting wordt door deze culturele verschillen ingegeven, en komt ook meestal in overleg met de peer voorlichters tot stand. Zij weten wat de doelgroep aanspreekt.

- De organisatie die de voorlichter vertegenwoordigt. Een peer voorlichter vertegenwoordigt ook altijd de organisatie die de boodschap bepaalt, of die de voorlichting betaalt. En dat kan voordelig of nadelig zijn, afhankelijk van het imago van de organisatie. Een peer voorlichter die de GGD vertegenwoordigt zal een betrouwbaar imago hebben. Dat zal niet voor elke zelforganisatie gelden die een of te modern of te traditioneel imago kunnen hebben waardoor de betrouwbaarheid wordt geschaad.

Deze dimensies kunnen in een schema worden gezet, met voorbeelden en valkuilen. Voor de voor-en-door methode is similariteit, het kenmerk waarmee de gelijkheid met de doelgroep wordt geclaimd, het belangrijkste. Maar waar het fout loopt in de ene dimensie, bijvoorbeeld geen optimale similariteit, kan worden gecompenseerd in een 
Schema A: Dimensies van het peerschap

\begin{tabular}{|c|c|c|c|}
\hline Kenmerk & Omschrijving & Valkuil & $\begin{array}{l}\text { Voorbeeldenl } \\
\text { grensgevallen }\end{array}$ \\
\hline Similariteit & $\begin{array}{l}\text { Het kenmerk waarmee } \\
\text { gelijkheid met de doelgroep } \\
\text { en het gemeenschappelijk } \\
\text { belang wordt geclaimd, } \\
\text { zoals seikse, leeftijd, etniciteit. } \\
\text { migrant zijn, taal, } \\
\text { homoseksueel zijn, } \\
\text { lotgenoot zijn, etc. }\end{array}$ & $\begin{array}{l}\text { Een kenmerk gebruiken } \\
\text { waarmee met het } \\
\text { onderwerp bij de } \\
\text { doelgroep geen wijgevoel } \\
\text { gecreeerd kan worden. }\end{array}$ & $\begin{array}{l}\text { Een wijkbewoner zal } \\
\text { een andere wijk- } \\
\text { bewoner moeilijker over } \\
\text { leefstijl kunnen aan- } \\
\text { spreken dan over } \\
\text { veiligheid van de straat. } \\
\text { In het laatste geval } \\
\text { is er méer gemeen- } \\
\text { schappelijk belang. }\end{array}$ \\
\hline Context & $\begin{array}{l}\text { De situatie waarin de } \\
\text { voorlichting plaatsvindt } \\
\text { zoals wijkcentrum. } \\
\text { gezondheidscentrum, } \\
\text { koffiehuis, 'de baan'. }\end{array}$ & $\begin{array}{l}\text { Een verkeerde context } \\
\text { voor het probleem/de } \\
\text { doelgroep/peer } \\
\text { combinatie }\end{array}$ & $\begin{array}{l}\text { Aids-voorlichting kan } \\
\text { wel in koffiehuizen. } \\
\text { maar in de moskee is } \\
\text { een grensgeval. }\end{array}$ \\
\hline Onderwerp & $\begin{array}{l}\text { Onderwerp van de } \\
\text { voorlichting, zoals Aids, } \\
\text { diabetes, gezond oud worden, } \\
\text { moeder en kindzorg. } \\
\text { zwangerschap en bevalling. }\end{array}$ & $\begin{array}{l}\text { Een taboeonderwerp, } \\
\text { of niet-passend onderwerp, } \\
\text { voor de doelgroepl } \\
\text { peer/context combinatie. }\end{array}$ & $\begin{array}{l}\text { Aids-voorlichting in de } \\
\text { moskee is een grens- } \\
\text { geval maar voorlich- } \\
\text { ting over gezondheids- } \\
\text { zorg kan daar prima. }\end{array}$ \\
\hline $\begin{array}{l}\text { Doel van de } \\
\text { voorlichting }\end{array}$ & $\begin{array}{l}\text { Van kennisoverdracht tot } \\
\text { gedragsmotivatie }\end{array}$ & $\begin{array}{l}\text { De peer voorlichter is } \\
\text { geen expert. hij is } \\
\text { vooral geschikt voor } \\
\text { gedragsmotivatie. }\end{array}$ & $\begin{array}{l}\text { Als inhoudelijk expert } \\
\text { valt de peer voorlichter } \\
\text { snel tegen voor } \\
\text { de doelgroep. }\end{array}$ \\
\hline $\begin{array}{l}\text { Vorm van de } \\
\text { voorlichting }\end{array}$ & $\begin{array}{l}\text { Van groepsvoorlichting } \\
\text { tot manifestatiewerk }\end{array}$ & $\begin{array}{l}\text { Onvoldoende aansluiten } \\
\text { bij de vorm die de doel- } \\
\text { groep aanspreekt. }\end{array}$ & $\begin{array}{l}\text { Formele groepsvoorlich- } \\
\text { ting voor bijv. Antillianen } \\
\text { die met zo'n vorm } \\
\text { moeilijk bereikt kunnen } \\
\text { worden. }\end{array}$ \\
\hline $\begin{array}{l}\text { Professio- } \\
\text { naliteit }\end{array}$ & $\begin{array}{l}\text { De mate van profession- } \\
\text { aliteit van de peer. De } \\
\text { opleidingen zijn divers: } \\
\text { van enkele weekenden } \\
\text { tot twee jaar. }\end{array}$ & $\begin{array}{l}\text { Te weinig opleiding } \\
\text { waardoor het vertrouwen } \\
\text { verdwijnt, te veel waar- } \\
\text { door de expertrol de } \\
\text { overhand kan krijgen. }\end{array}$ & $\begin{array}{l}\text { De migrantervvoor- } \\
\text { lichtsters hebben in de } \\
\text { eerste lijn mér } \\
\text { inhoudelijke expertise } \\
\text { nodig dan in de } \\
\text { wijkcentra. }\end{array}$ \\
\hline $\begin{array}{l}\text { Zelfstan- } \\
\text { digheid }\end{array}$ & $\begin{array}{l}\text { De mate van zelfstandigheid } \\
\text { van de peer voorlichter }\end{array}$ & $\begin{array}{l}\text { Te grote zelfstandigheid } \\
\text { vraagt te veel van de } \\
\text { deskundigheid, maar met } \\
\text { te weinig zelfstandigheid } \\
\text { kan onvoldoende flexibel } \\
\text { op de doelgroep worden } \\
\text { gereageerd. }\end{array}$ & $\begin{array}{l}\text { Er zijn grote individuele } \\
\text { verschilien tussen } \\
\text { migrantenvoorlichtsters } \\
\text { met betrekking tot hun } \\
\text { zelfstandigheid }\end{array}$ \\
\hline $\begin{array}{l}\text { Rol van de } \\
\text { voorlichter }\end{array}$ & $\begin{array}{l}\text { De peer voorlichter kan expli- } \\
\text { ciet (Wij. Turkse mannen...) } \\
\text { of impliciet (kleding, accent } \\
\text { e.d.) similariteit versterken of } \\
\text { verzwakken. }\end{array}$ & $\begin{array}{l}\text { Een verkeerd beroep } \\
\text { doen, foute kleding. } \\
\text { verkeerde dialect, etc. }\end{array}$ & $\begin{array}{l}\text { Er kan overeenkomst in } \\
\text { etniciteit zijn maar het } \\
\text { het leeftijdsverschil } \\
\text { kan te groot zijn. }\end{array}$ \\
\hline $\begin{array}{l}\text { Verwachtingen } \\
\text { van de } \\
\text { doelgroep }\end{array}$ & $\begin{array}{l}\text { Verwachtingen over bijv. } \\
\text { expertise en over } \\
\text { similariteit. }\end{array}$ & $\begin{array}{l}\text { De verwachting van de } \\
\text { doelgroep komt niet over- } \\
\text { een met de feitelije situatie }\end{array}$ & $\begin{array}{l}\text { De doelgroep vindt de } \\
\text { voorlichter te weinig } \\
\text { deskundig. }\end{array}$ \\
\hline $\begin{array}{l}\text { Gedrag in } \\
\text { relatie tot het } \\
\text { doel }\end{array}$ & $\begin{array}{l}\text { Rond taboeonderwerpen } \\
\text { wel/geen expliciete } \\
\text { termen gebruiken, } \\
\text { een condoomdemo. }\end{array}$ & $\begin{array}{l}\text { Onvoldoende invoeien hoe } \\
\text { met deze doelgroep } \\
\text { orn te gaan. }\end{array}$ & $\begin{array}{l}\text { Van de doelgroep ver- } \\
\text { wijderd raken of zelfs } \\
\text { shockeren. }\end{array}$ \\
\hline $\begin{array}{l}\text { Organisatiel } \\
\text { opdracht- } \\
\text { gever }\end{array}$ & $\begin{array}{l}\text { De organisatie voor wie } \\
\text { de peer voorlichter optreedt. }\end{array}$ & $\begin{array}{l}\text { Het imago van de } \\
\text { organisatie is niet voor- } \\
\text { delig voor de voorlichter }\end{array}$ & $\begin{array}{l}\text { Een te links of te rechts } \\
\text { imago van zelforganisa- } \\
\text { ties kan een peer parten } \\
\text { spelen }\end{array}$ \\
\hline
\end{tabular}


andere dimensie, zoals het voorbeeld van de Turkse aidsvoorlichter die een groep van oudere Turkse mannen aanspreekt als Turkse ouders. 'Wij, Turkse jongeren, moeten er toch voor zorgen dat we geen onnodig risico lopen!'.

De dimensies moeten in een bepaalde concrete situatie zodanig worden ingevuld dat ze elkaar versterken en niet tegenwerken, wil de voorlichting effectief zijn. Een suboptimale situatie in de ene dimensie kan worden gecompenseerd door een andere dimensie. Die invulling bepaalt de effectiviteit in een concrete situatie. Om de potentiële werkzaamheid te beoordelen kan bij elke verschijningsvorm nagegaan worden wat het 'peerschap' is, en of het een kans van slagen heeft. Daarvoor is noodzakelijk dat we die werkzaamheid kunnen beschrijven vanuit een theoretisch model. Hieronder wordt nagegaan welke aangrijpingspunten er zijn voor de werkzaamheid van de peer methode in de verschillende modellen en theorieën in gezondheidsbevordering.

\subsection{Theoretische onderbouwing van peer voorlichting}

Peer methodes in gezondheidsbevordering zijn vaak ontstaan in situaties waar de voorlichter of de voorlichtingsinstantie de doelgroep niet kon bereiken. Bijvoorbeeld bij het bereiken van migranten speelt het probleem van de taal, en daarom is de migrantenvoorlichting, de voorlichting in de eigen taal en cultuur (vetc) ontstaan. Bij homo's speelt de specifieke subcultuur waaruit projecten als aids-voorlichting op de 'baan' zijn ontstaan. Peer methodes ontstaan waar de voorlichtende instantie het idee heeft dat er sprake is van een moeilijk bereikbare doelgroep. Peer methodes zijn vaak uit nood geboren! Ze vinden hun oorsprong meestal in de praktijk van de gezondheidsbevordering. Mogelijk is dat ook één van de redenen waarom de theoretische onderbouwing gebrekkig is. De start van een peer project kan liggen in de simpele constatering dat de doelgroep bereikt kan worden door samen te werken met de mensen die de doelgroep klaarblijkelijk wel bereiken, zoals in het geval van migranten hun zelforganisaties en verenigingen. Het is een kleine stap om diezelfde 'vertegenwoordigers' van de doelgroep in te schakelen voor de uitvoering van de voorlichting. Veel theorie komt daar dus niet aan te pas. Turner en Shepherd (1999) noemen peer voorlichting vanwege die theoriearmoede daarom 'a method in search of a theory'. Zij gaan in onderzoeksen projectverslagen na waarom de peer methode werd gebruikt, en ze gaan na of die claims vanuit de theorie kunnen worden onderbouwd. Nutbeam \& Harris (1998) geven een overzicht van de meest gebruikte theorieën in gezondheidsbevordering. Er zijn drie theorieën die goede aangrijpingspunten bieden om de werkzaamheid van de peer methode te beschrijven: de sociale leertheorie van Bandura, de sociale vergelijkingstheorie van Festinger en de diffusietheorie van Rogers (Bandura, 1986; Festinger, 1954 in Meertens en Grumbkow, 1992; Rogers, 1983). Hieronder worden de meest gangbare theorieën en modellen in gezondheidsbevordering besproken om na te gaan wat zij voorspellen over de werkzaamheid van de peermethode.

\subsubsection{De sociale leertheorie}

De sociale leertheorie van Bandura, later uitgewerkt in de sociaal-cognitieve theorie is 
volgens Nutbeam de meest complete theorie die op dit moment wordt toegepast in gezondheidsbevordering omdat de theorie niet alleen de determinanten van gezondheidsgedrag beschrijt, maar ook voorschrijft hoe verandering van dat gedrag kan worden bereikt (Nutbeam \& Harris, 1998). Een belangrijk concept in de theorie is het wederzijds determinisme. Dat wil zeggen dat de persoon onder invloed kan staan van zijn omgeving en tegelijkertijd die omgeving kan beïnvloeden. Omgeving, gedrag en de persoon zijn in een continu proces van interactie verbonden. Verder zijn in dit model drie kenmerken van het leren van mensen van belang. Ten eerste kunnen mensen leren door anderen te observeren: door het gedrag van de ander en de consequenties van dat gedrag in de omgeving te observeren en zich in te leven het zelf te doen (modelling). Ten tweede zijn mensen in staat om te anticiperen op de uitkomst van de verschillende geobserveerde gedragspatronen. Ze ontwikkelen verwachtingen over de uitkomsten van het gedrag in de bepaalde situatie. Het derde belangrijke aspect dat het gedrag bepaalt is het geloof in eigen kunnen: het geloof in het eigen vermogen om het gedrag in een specifieke situatie op een succesvolle manier te laten zien. Dat is de verwachting met betrekking tot de eigen effectiviteit ('self-efficacy'). Bandura stelt dat het leren door observeren, en het leren door oefening beide de eigen effectiviteit kan versterken. Een sleutelwoord in de theorie is de 'vicarious experience'. Vicarious betekent letterlijk 'in plaats van de ander': 'Seeing or visualizing other similar people perform can raise self-percepts of efficacy...(Bandura, 1986: p. 399). Dat lijkt terug te gaan tot de basis van menselijke communicatie. In het symbolisch interactionisme van Mead is 'taking the role of the other' het centrale mechanisme waardoor zin (betekenis), zelfbewustzijn en intelligentie kunnen ontstaan (Zijderveld, 1973). Dit aspect van role-taking is een sterke ondersteuning voor de peer methode als zodanig: 'Als hij het kan of zegt te kunnen, en hij is net zoals ik, of zoals ik zou willen zijn, dan kan ik het ookl'. Uit deze theoretische gedachtegang kunnen enkele praktische kenmerken van de peer worden afgeleid. De peer voorlichter moet zijn zoals de doelgroep is, of zou willen zijn. De peer voorlichter moet in zijn verschijning en zijn gedrag nastrevenswaardig zijn. Hij is het rolmodel. Daarin zit een paradox verscholen: hij moet gelijk zijn aan de leden van de doelgroep, maar wel iets 'beter'. Het meest compact geformuleerd: hij moet een primus inter pares zijn. De 'eerste onder zijn gelijken' heeft de beste kaarten in handen om een effectieve peer voorlichter te zijn. De invloed van dat rolmodel kan bij de doelgroep op een bewuste of onbewuste manier tot stand komen. Het hoeft dus geen beredeneerd gedrag te zijn. Als geheel ondersteunt de sociale leertheorie de strategie van peer voorlichting, en verklaart waarom een lid van een doelgroep onder condities effectief kan worden ingeschakeld bij gezondheidsvoorlichting. Daar waar modelling of model leren als methode voor gedragsverandering wordt gezien, zou de peer methode overwogen moeten worden. Turner \& Shepherd zien ook dat de werkzaamheid van de peer voorlichter in de praktijk vaak wordt geclaimd vanuit zijn voorbeeldgedrag. Toch werkt dat in de praktijk niet automatisch. In de migrantenvoorlichting zijn legio voorbeelden van problemen met het rolmodel. Turkse voorlichtsters die zelf roken, en het roken ook nog steeds zien als teken van onafhankelijkheid, en daardoor niet kunnen meewerken aan programma's gericht op het stoppen met roken. De voorlichtster die te modern 
gekleed is, en ook voor westerse begrippen te bloot gekleed is, en daardoor in veel groepen niet geaccepteerd werd. (Maar misschien bij de jongeren juist weer wel?). Er worden door de voorlichtsters steeds discussies gevoerd over dit aspect van het werk: het rolmodel zijn. Wat betekent dat, en welke consequenties heeft het? Moet je je aanpassen aan de groep? Moet je in sommige groepen een hoofddoekje omdoen? Een hieraan gerelateerde claim die Turner \& Shepherd noemen is dat de peer voorlichter door de doelgroep langer geaccepteerd wordt dan andere vormen van voorlichting. Als er veel vertrouwen is tussen de doelgroep en de voorlichter dan zal die voorlichter een groot 'voordeel van de twijfel' hebben. Men zal langer blijven luisteren. Dat is de kracht van de peer voorlichter. Een peer voorlichter kan met een 'onwaarschijnlijke' bewering de doelgroep in de war brengen en aan het denken zetten terwijl die beweringen van een buitenstaander gemakkelijker als niet relevant terzijde gelegd worden. De Turkse aidsvoorlichter die beweert altijd een condoom te gebruiken, zal de Turkse mannen meer aan het denken zetten dan een Nederlandse moderne man die hetzelfde beweert! Tegelijkertijd zijn er in het peerschap zelf elementen die de voorlichtingsboodschap ook in de weg kunnen staan. Denk aan de Aidsvoorlichter die moet beoordelen hoe acceptabel in een specifieke situatie een condoomdemonstratie is. In een bepaalde cultuur kan dat bij een bepaalde doelgroep te gênant, te pijnlijk zijn. Soms kan de buitenstaander, juist vanwege het feit dat hij buitenstaander is en de cultuur niet kent, méér 'maken' dan de voorlichter. De buitenstaander zal waarschijnlijk toch minder overtuigend zijn 'omdat hij toch niet weet hoe dat bij ons gaat'.

\subsubsection{De sociale vergelijkingstheorie}

Volgens de sociale vergelijkingstheorie van Festinger proberen mensen hun opvattingen te vergelijken met die van anderen, vooral in situaties waarin men onzeker is over de eigen opvatting (Festinger, 1954). Men wil graag gelijke opvattingen hebben met de anderen die tot de eigen referentiegroep behoren. De referentiegroep bestaat uit personen die reeds op een aantal andere punten gelijk zijn. Mensen hebben de neiging om zichzelf en anderen in te delen in categorieën waarbij ze zichzelf vergelijken met groepen waarvan ze lid zijn of zouden willen zijn, en zich juist afzetten tegen groepen waarvan men geen lid wil zijn. Juist in die situaties waarin objectieve, controleerbare informatie ontbreekt, zal men geneigd zijn zich te conformeren aan de referentiegroep. Als de peer voorlichter door de doelgroep wordt gerekend tot de eigen referentiegroep dan is dat een basis voor de potentiële overtuigingskracht van de peer voorlichter. Buunk e.a. geven een historisch overzicht van het gebruik van de sociale vergelijkingstheorie op het gebied van gezondheid en ziekte (Buunk e.a., 1997). Dat overzicht is relevant voor gezondheidsbevordering, want het betreft theorievorming over de effecten van lotgenotencontact als de intermediair tussen gezondheidsprobleem en de gezondheidsbeleving en bijvoorbeeld het effect op risicoperceptie van bijvoorbeeld Aids. Opvallend is dat in dat overzicht de voor-en-door methode bij de gezondheidsvoorlichting ontbreekt. In het hoofdstuk over Aids preventie concluderen Misovich e.a. de potentiële kracht van zo'n strategie 'by using social comparison others who are trained to advocate preventive behavior....' (Misovich e.a., 1997). Als het gaat om risicoperceptie kan een 
peer die een gezondere leefstijl heeft, dienen als rolmodel voor die leefstijl. En een peer die zegt veel risico te lopen, maar verder gelijk is met de doelgroep, kan de risicoperceptie in de gewenste richting beïnvloeden. Toch is volgens de sociale vergelijkingstheorie de toepassing van de 'peer' in een voorlichtingsstrategie niet eenvoudig omdat mensen veel strategieën hanteren om hun eigen opvattingen te handhaven. Het kan bijvoorbeeld tot gevolg hebben dat men de eventuele verschillen met de peer die zelf zegt risico te lopen, gaat uitvergroten. Met het gevolg dat men juist in averechtse richting verandert met betrekking tot de risicoperceptie. En er kan behalve een opwaartse ook een neerwaartse vergelijking met de peer gemaakt is. Zeker bij patiëntenvoorlichting kan de vergelijking met mensen die er erger of juist beter aan toe zijn, het welbevinden van mensen positief of negatief beïnvloeden. Buunk spreekt dan ook heel beeldend van de 'zilveren medaille van de sociale vergelijking'. In opwaartse zin wordt vergeleken met de gouden medaille en in neerwaartse zin met de bronzen medaille. Een gouden medaille kan in tweede instantie toch een zilveren medaille blijken te zijn, want men blijt nu eenmaal vergelijken. En een medaille heeft twee kanten: de opwaartse vergelijking kan tot zelfverbetering leiden maar ook tot onaangename en weinig opbouwende gevoelens van afgunst (Buunk, 1992). De sociale vergelijkingstheorie biedt zeker een theoretische basis voor de voor-en-door voorlichting, maar de theorie wijst erop dat effectiviteit niet vanzelfsprekend is, en zelfs dat er kansen op averechtse effecten bestaan. Van groot belang is een zorgvuldige keuze van de peers voor de betreffende doelgroep.

\subsubsection{De diffusie van innovatietheorie}

De theorie over de diffusie van innovaties van Rogers beschrijt en verklaart ten dele de verspreiding van ideeën over een gemeenschap (Rogers, 1983). De diffusietheorie beschrijt de wijze waarop innovaties via communicatie verspreid worden onder de leden van een bepaald sociaal systeem. Een innovatie is een idee, gedrag of ding dat als nieuw wordt gezien. Rogers beschrijt de vijf fases van het adoptieproces op het individuele niveau: kennisfase, overtuigingsfase, besluitvormingsfase, implementatiefase en bevestigingsfase. En hij beschrijt het adoptieproces op populatieniveau, met zijn bekende S-curve. Adoptie start met een kleine groep 'vernieuwers', daarna volgt een iets grotere groep 'vroege adopters', daarna volgt de grote groep vroege en late meerderheid, en ten slotte weer de kleinere groep achterblijvers. De adoptie van een innovatie is ook afhankelijk van de kenmerken van die innovatie:

- De mate waarin de adoptie verenigbaar is met heersende sociaal-economische en culturele waarden.

- Het relatieve voordeel (bruikbaarheid, gemak en prestige) afgewogen tegen de kosten,

- De eenvoud of complexiteit,

- De omkeerbaarheid en de ervaren risico's,

- De observeerbaarheid van de resultaten van de adoptie, vooral voor diegene die de adoptie overwegen. En nog vele andere kenmerken.

Voor de relatie met de peer methode is interessant dat Rogers de kenmerken beschrijft 
van de 'change agent' en van de zogenaamde 'aide'. De change agent en de aide zijn de personen die de adoptie van de verandering faciliteren. De 'aide' is een minder professionele change agent die middels intensieve kontakten met de cliënt de innovatiebeslissingen beînvloed. Het succes van de change agent is positief gerelateerd aan: - De mate van contact met de cliënten,

- De mate van cliëntoriëntatie in plaats van agency oriëntatie,

- De empathie van de change agent met de cliënten,

- De mate van homophily met de cliënten,

- De geloofwaardigheid in de ogen van de cliënten,

- De mate waarin hij werkt via opinion leaders in de gemeenschap.

Vanuit de theorie voorspelt Rogers dat de change agent vooral contact zal hebben met cliënten met een relatief hoge status, met veel sociale participatie, met een hogere opleiding en met een meer kosmopolitische in plaats van een lokale oriëntatie. De 'aide'(lett. lemand die helpt) is minder professioneel dan de change agent. Letterlijk zegt Rogers dat de aide 'helps to bridge the heterophily gap between the professional (change agent) and the client'. De aide heeft minder 'competence credibility' (competentie geloofwaardigheid: de mate waarin de communicatiebron wordt ervaren als veelwetend en deskundig), maar hij heeft een grotere 'safety credibility' (de mate waarin de communicatiebron wordt ervaren als betrouwbaar). En dat is vooral te danken aan zijn homophily met zijn cliënten. 'Inauthentic professionalisation' is het proces waarbij de aide zich te veel gaat identificeren (bijvoorbeeld via kleding, of gedrag) met de change agent. Alles wat Rogers zegt over de change agent geldt in mindere mate voor de aide. En alles wat Rogers zegt over de change agent en de aide is zeer relevant in relatie tot het werk van een peer voorlichter. Wat hij zegt over de aide geldt in grote mate ook voor de peer voorlichter. Met de beschrijving van de aide worden de voordelen van de peer voorlichter beschreven. Bijvoorbeeld de relatie tot de functionarissen van de GGD, maar ook de mogelijke problemen van niet-authentieke professionalisatie. Turner \& Shepherd vinden in de onderzochte projecten vaak de claim van de peer voorlichter als een geloofwaardige bron. Maar de peer is vooral geloofwaardig vanwege zijn betrouwbaarheid en niet noodzakelijk vanwege zijn expertise. Een betrouwbare peer zonder expertise zal echter niet lang geloofwaardig zijn. Voor de migrantenvoorlichtsters is vooral het begin van hun werk vaak moeilijk: ze worden op de proef gesteld, hun kennis wordt getest. Tenminste, zo ervaren de voorlichtsters het. Voor de voorlichtster is het de kunst om voldoende zelfvertrouwen te verwerven zodat het meedelen geen antwoord te weten op een vraag geen echte bedreiging meer is. Voor een effectieve inzet moet dus een evenwicht gevonden worden tussen de rol van deskundige en de procesbewaker. De geloofwaardigheid door betrouwbaarheid van de peer is zijn sterke kant, maar is tegelijkertijd kwetsbaar. De geloofwaardigheid kan gemakkelijk worden aangetast, zelfs door toevallige omstandigheden zoals aan het begin van dit hoofdstuk met de Marokkaanse voorlichtster die alleen door haar achternaam niet meer werd vertrouwd. Ook is het denkbaar dat het onderwerp van de voorlichting een bedreiging kan zijn voor de voorlichter. Hoe acceptabel is het voor een Marokkaanse man om 
in een koffiehuis over Aids te spreken? Het is denkbaar dat het onderwerp van de voorlichting de betrouwbaarheid en dus de geloofwaardigheid te niet doet. (Vergl. Voorham e.a., 2002).

Samengevat, kan de peer worden opgevat als een aide van de change agent en mogelijk ook als een change agent vanuit de gemeenschap zelf. De peer strategie kan gemakkelijk onderbouwd worden met de adoptie-innovatie-theorie, zeker in combinatie met de sociale leertheorie. Waar de professionele change agent de doelgroep niet bereikt, vanwege verschillen in status, cultuur, opleiding, ofwel gebrek aan homophily of 'gelijkheid' kan een peer strategie worden overwogen.

\subsubsection{Het persuation-communication model}

McGuire heeft de voorwaarden voor gedragsverandering via, vooral de massamediale communicatie schematisch weergegeven in een matrix met in de ene dimensie de inputvariabelen (bron, boodschap, kanaal, ontvanger) en de andere dimensie de output variabelen: blootstelling, aandacht, interesse, begrip, vaardigheden, attitudeverandering. besluitvorming, gedragsverandering en gedragsbehoud. (McGuire, 1985). In dit model is de peer voorlichter op de eerste plaats de bron van de boodschap, al is de instantie voor wie de voorlichter werkt ook deel van die bron. Maar de peer voorlichter is óók kanaal, in combinatie met de werkvorm (groepsvoorlichting, individuele voorlichting. etc.) die wordt gebruikt. Wat McGuire zegt over de bronvariabelen en de kanaalvariabelen moet dus gelden voor de peervoorlichter. Voor de overtuigingskracht van een bron zijn drie dingen van belang: geloofwaardigheid, attractiviteit en de macht van de bron. Een bron is geloofwaardig als hij competent en betrouwbaar wordt gevonden. (De Vries, in Meertens \& Von Grumbkow, 1992). Competent is iemand die onderwijs heeft genoten, iemand die als verstandig overkomt, en een hoge status heeft. De betrouwbaarheid van de bron wordt ook bepaald door de oprechtheid en door de motivatie van de bron. De attractiviteit wordt bepaald door de fysieke aantrekkelijkheid, door non-verbaal gedrag en door similariteit ofwel de mate van gelijkheid. Daarbij kan men denken aan gemeenschappelijke waarden, taalgebruik, verschijning, kleding, de soort humor, etc. Voor de migrantenvoorlichtster speelt steeds weer de vraag over kleding: hoe modern, wel of geen hoofddoekje? Maar kleding en taalgebruik kan ook subtieler een rol spelen bij een gevoel van verbondenheid met de peer voorlichter. McGuire maakt duidelijk dat een peer voorlichter binnen de groep het beste een hoge status kan hebben, en mogelijk kan een peer als vertegenwoordiger van een betrouwbare organisatie zijn eigen geloofwaardigheid vergroten. Een seniorenvoorlichter of een migrantenvoorlichter kan als vertegenwoordiger van de GGD dus geloofwaardiger worden gevonden! Diezelfde voorlichter verdient echter ook geld met de voorlichting, en dat is mogelijk niet de beste motivatie met betrekking tot de geloofwaardigheid. Het kan zijn oprechtheid aantasten: "Je zegt dit alleen maar omdat je betaald wordt om dit te zeggenl:

Bij de kanaalvariabelen van McGuire wordt gelet op bereik, de kosten, en de complexiteit van de boodschap die nog kan worden gecommuniceerd. Turner \& Shepherd komen vaak de claim tegen dat de peer methode meer kosteneffectief zou zijn dan andere methodes. Mogelijk komt dat omdat zij veel peer projecten op scholen beschrij- 
ven waarbij leerlingen worden ingeschakeld om hun leeftijdsgenoten met gezondheidsvoorlichting te bereiken. Dat zal wellicht goedkoper zijn dan een voorlichter in de klas te laten optreden. In het algemeen kan over kosteneffectiviteit in relatie tot peer voorlichting geen uitspraak worden gedaan. Kosteneffectiviteit doet een uitspraak over de verhouding tussen de kosten en effecten. Het kan bij peer voorlichting juist ook om arbeidsintensieve projecten gaan. Het gaat om persoonlijke voorlichting waarbij vergaande veranderingsdoelen worden nagestreefd. Vergeleken met massamedia bijvoorbeeld zal het bereik kleiner zijn maar die kleinere doelgroep wordt intensiever benaderd. Er is dus een afweging noodzakelijk die in vergelijking met het economische begrip 'elasticiteit van de vraag' (Een lage prijs met een grote omzet vs. een kleine omzet tegen een hogere prijs) de elasticiteit van effectiviteit genoemd kan worden (Vergl. Voorham \& Reelick, 1986). In het proces van intervention mapping moet een keuze worden gemaakt tussen een groot bereik met een klein effect vs. een klein bereik met een groter effect. Die elasticiteit van het effect is van vele andere factoren afhankelijk zoals de fase van verandering van de doelgroep, het gezondheidsgedrag en de determinanten daarvan. In de meeste gevallen zal de peer methode een kostenintensieve methode zijn die alleen verdedigbaar is als het gezondheidsgedrag relatief moeilijk veranderbaar is, bijvoorbeeld omdat de doelgroep moeilijk bereikbaar is, of omdat de doelgroep alleen met een intensieve persoonlijke benadering te motiveren is. Als het gaat om bereik en kosten van Nederlandse peer voorlichting waarbij voorlichters zijn aangesteld bij een organisatie, dan heeft peer voorlichting in ieder geval de schijn tegen: de meeste massamedia hebben een groter bereik, en zijn dus waarschijnlijk goedkoper. Het model van McGuire laat zien dat massamedia misschien wel een groter bereik hebben maar dat de laatste stappen naar gedragsverandering via de massamedia juist zo moeizaam gehaald kunnen worden. En een voordeel van de peer voorlichting is ook dat complexe boodschappen kunnen worden behandeld omdat er meestal onmiddellijke interactie met de doelgroep mogelijk is. Of de methode meer kosteneffectief is, kan zonder duidelijke empirische vergelijking niet worden vastgesteld. Het matrixmodel van McGuire is ontwikkeld voor massamedia, en het gebruik van het model bij peer voorlichting past niet goed. Het model laat zien waaraan de peer als 'bron' van de boodschap in het ideale geval moet voldoen, en laat zien dat de peer methode een aantal sterke troeven in handen heeft.

\subsubsection{Wijkgerichte en gemeenschapsgerichte strategieën ('community interventions')}

Uiteindelijk gaat het bij gezondheidsbevordering niet om de gezondheid van het individu en het individueel gezondheidsgedrag maar om de gezondheid van populaties, en om het gezondheidsgedrag van populaties. En die kunnen ook niet los van elkaar gezien worden zoals Bandura al betoogde met het wederzijds determinisme. Daarom zijn in gezondheidsbevordering de samenlevingsgerichte interventies van belang. Nutbeam en Harris onderscheiden in navolging van Rothman en Tropman in een typologie drie verschillende benaderingen: wijkgericht werken ('locality development' of beter 'community development'), sociale planning en sociale actie (Rothman en Tropman, 1987). 
Bij wijkgericht werken gaat het om het bevorderen van participatie en het nemen van de eigen verantwoordelijkheid met betrekking tot het gezondheidsprobleem. Sociale planning is meer taakgericht en gebaseerd op het expertmodel. Het gaat hierbij bijvoorbeeld om op epidemiologisch en sociaal wetenschappelijk onderzoek gebaseerde planning van interventies. Het derde model van de sociale actie gaat uit van het versterken van de gemeenschap. En het gaat daarbij vaak om het veranderen van machtsrelaties, en de inzet van sociale actie. In de community development is participatie en het betrekken van de doelgroep bij de ontwikkeling en uitvoering van de interventie belangrijk. Arnstein (1969, in Goumans, 1998) heeft een participatieladder ontwikkeld waarbij de participatiegraad van de doelgroep met elke trede toeneemt. De hoogste vorm van participatie is de volledige controle over het project door de doelgroep. Een van de stadia is ook de uitvoering van de interventie door de doelgroep. Op die manier bezien is de voor-en-door voorlichting ook een methode voor participatie van de doelgroep. In de praktijk van de gezondheidsbevordering ontstaat er op meer sporten van de participatieladder betrokkenheid: zelforganisaties van de doelgroep worden betrokken bij de planvorming, de doelgroep wordt betrokken bij de vormgeving van de interventie. En als vanzelfsprekende volgende stap wordt de doelgroep ingeschakeld voor de uitvoering in de vorm van peer voorlichting. $\mathrm{Er}$ is in feite een oplopende mate van controle door de doelgroep in de reeks sociale planning, community development en sociale actie. Bij de sociale planning zal de peer voorlichting de vorm krijgen van de 'lay health advisor', goed getraind en ondersteund door een professionele organisatie voor de concrete uitvoering van de voorlichtingsbijeenkomsten. Bijvoorbeeld de migrantenvoorlichtsters die door de GGD in buurthuizen worden ingeschakeld om in de eigen taal voorlichting te geven. Bij de community development ligt er al meer eigen verantwoordelijkheid bij de peer voorlichter. Daarbij gaat het dus ook om de vraag in hoeverre de peer gebruik maakt van zijn bestaande netwerken of niet (Zie ook Backett-Milburn \& Wilson, 2000). Een voorbeeld is het lopende project Amor i Salú waarbij Antilliaanse zelforganisaties in Rotterdam uitgebreid betrokken worden bij de ontwikkeling en uitvoering van een aidspreventieproject (Kocken e.a., 2002). Bij het actiemodel gaat het om het beïnvloeden van een machtsbalans door middel van actie. Vaak is een kenmerk dat het probleem in eerste instantie niet of onvoldoende door de overheid wordt erkend. Een voorbeeld daarvan zijn de acties rond de vervuilde grond zoals die ook in Rotterdam hebben plaatsgevonden. Over het algemeen zijn community trajecten en peer strategieën nauw met elkaar verbonden: een community strategie zonder peer strategie is feitelijk ondenkbaar. Dat wil zeggen als er werkelijk sprake is van 'community' zoals Tönnies dat bedoelt met 'Gemeinschaft', in tegenstelling tot 'Geselschaft' of samenleving (Tönnies in Goddijn e.a., 1974). Bij de Gemeinschaft is er een gemeenschapsgevoel, een wij-gevoel, maar bij de Geselschaft is er alleen een geografisch of anderszins bepaalde categorie van mensen. Bij de community strategie wordt dus een beroep gedaan op een wij-gevoel, en als daarbij dan ook uitvoerende voorlichting een rol speelt, dan ligt de community strategie en de peerstrategie in elkaars verlengde. Dit is de dieper liggende reden voor het feit dat het niet gelukt is in Rotterdam een voor-endoor traject voor autochtone wijkbewoners te starten rond leefstijlonderwerpen: het 
wijgevoel in een aantal wijken, ofwel het wijkgevoel is flinterdun! Bij een ander onderwerp zoals kinderveiligheid of vervuilde grond is dat gemeenschapsgevoel er wél, en kunnen er wél wijkgerichte acties ontstaan.

Vanuit het idee van de peer voorlichting als een verlengde van de community benadering komen Turner \& Shepherd met de claim dat de peer methode vooral de bestaande vormen van informatie-uitwisseling gebruikt. In de context van de community benadering klopt dat: er wordt gebruik gemaakt van bestaande sociale relaties en netwerken, en dus gebruikt de peer methode diezelfde netwerken. Dit is ongetwijfeld een belangrijke reden voor de potentiële effectiviteit maar het is ook een factor die per vorm van de peer methode sterk kan variëren. Het is niet zo dat in de praktijk van de migrantenvoorlichting de bestaande sociale relaties worden gebruikt. De aidsvoorlichter die bij een specifiek koffiehuis langs gaat zou in zijn eigen dagelijkse leven een ander koffiehuis bezoeken. Migrantenvoorlichters hebben wel aangegeven dat ze de voorkeur geven aan groepsvoorlichtingen in buurthuizen buiten hun eigen woonwijk. Als het gaat om gebruik maken van bestaande vormen van informatiediffusie dan is dat in dit geval geredeneerd vanuit de etnische groep als geheel en niet in de eerste plaats de bestaande sociale relaties van de peer voorlichter. Hieraan gerelateerd is de claim dat met peer voorlichting het leren wordt herbevestigd door het voortdurende contact met doelgroep, zoals Turner en Shepherd beschrijven. In veel peer voorlichtingsprojecten zal dat niet kloppen omdat het uitgaat van de vooronderstelling dat de peer vooral via zijn eigen sociale systeem zal werken. En dat is nu juist vaak niet het geval.

Bij de community benaderingen, de bottom up strategieën, worden vaak empowerment doelstellingen geformuleerd, ook voor al diegenen die daarbij betrokken zijn, en dus ook voor de betrokken peer voorlichters. Turner $\&$ Shepherd onderzoeken de claim of de voorlichting ook voor de peer voorlichter zelf voordelig is. Volgens hen laat de auteur Peers e.a. (1993) (Wat een toeval!) zien dat een HIVIAids-project voor jongeren voor-delig is geweest voor de voorlichter in termen van vaardigheden en persoonlijke ontwikkeling. Datzelfde is geclaimd bij bijvoorbeeld Sexplain-projecten waarbij jonge homoseksuele mannen voorlichtingsbijeenkomsten hebben met jongeren die nog maar net toegeven aan hun homoseksualiteit (Wagemans e.a.,1998). Bij een Rotterdams theaterproject met allochtone jongeren ('Over de grens' met de multiculturele jongerentheatergroep 'Rotterdams Lef') is dat effect voor iedereen die dichtbij de groep stond heel vanzelfsprekend: de jongeren verwierven in dit project een veel zelfbewuster houding (Butte, 1996). Bij migrantenvoorlichting wordt het emancipatorische doel naar de voorlichter toe expliciet benoemd. En met name voor de vrouwelijke voorlichtsters is de zogenaamde kadercursus migrantenvoorlichting een belangrijke stap in hun loopbaan. Er zijn vele voorbeelden te geven van met name Turkse en Marokkaanse vrouwen die doorgestroomd zijn in het maatschappelijk werk. Voor de vrouwen is dat wel een lange, maar waarschijnlijk de enig mogelijke weg. Hoewel het als expliciet doel wordt geformuleerd is er over het emancipatorische effect van peer trajecten, en meer in het bijzonder van migrantenvoorlichting geen onderzoeksresultaat beschikbaar. Er zijn mogelijk ook nadelen voor de persoon. Er kan door organisaties een te grote verwachting worden 
gekoesterd met betrekking tot het vermogen om de doelgroep te bereiken. Steeds maar weer aangesproken worden op het moeten bereiken van de achterban, kan een grote druk op de persoon van de peer tot gevolg hebben. Het is de vraag welk gevolg het heeft als een vrouw op de eerste plaats werk heeft omdat ze Turkse vrouw is, en pas op de tweede plaats omdat ze een vaardigheid heeft. Er zijn vele voorbeelden van voorlichtsters voor wie het een overwinning was dat ze in een nieuwe baan 'algemeen' inzetbaar werden.

\subsubsection{Samenvatting van de theoretische onderbouwing}

De meeste ondersteuning voor de peer methode kan worden gevonden in de sociale leertheorie van Bandura en in de sociale vergelijkingstheorie van Festinger. Het mechanisme van de effectiviteit van de peer voorlichting kan goed in de termen van de sociale leertheorie worden omschreven, en kan worden samengevat met de omschrijving van een peer voorlichter als rolmodel voor zijn doelgroep. Volgens de sociale vergelijkingstheorie moet gezocht worden naar de randvoorwaarden van een opwaartse vergelijking, zodat de peer voorlichter daadwerkelijk een rolmodel kan zijn. De community interventie theorieën leggen veel nadruk op de betrokkenheid en participatie van de doelgroep, op het vergroten van de competenties in de gemeenschap, en op bottom up strategieën. Peer voorlichting is een manier om de doelgroep op een intensieve manier bij gezondheidsbevordering te betrekken. Het is daarom dan ook heel begrijpelijk dat juist in de community projecten peer strategieèn vaak worden toegepast. Een stevige ondersteuning voor de peer methode geeft Rogers in zijn diffusietheorie. In zijn omschrijvingen van de effectieve change agent en de aide voor de change agent kunnen veel kenmerken van de peer voorlichter worden gelezen. De communicatiepersuation matrix van McGuire wijst op het belang van bronkenmerken die de peer moet hebben om effectief te zijn zoals met name betrouwbaarheid en similariteit.

\subsubsection{De ideale peer voorlichter}

$\mathrm{Na}$ deze theoretische rondgang kunnen we de eigenschappen van een ideale peer voorlichter schetsen. Die eigenschappen zijn van belang bij de selectie van de voorlichters, de scholing, de ondersteuning bij de inzet, en de marketing rond de peer voorlichting. Een effectieve peer voorlichter moet in staat zijn bij zijn doelgroep een wij-gevoel te creëren, hij moet vergeleken met zijn doelgroep een iets hogere status hebben. Maar niet té hoog want hij moet voor de doelgroep haalbaar nastrevenswaardig zijn. Hij is een rolmodel. In kleding, uiterlijk en taalgebruik (dialecten!) mag hij niet uit de toon vallen, want hij moet bij de groep horen. Op de eerste plaats, en dat is vaak ook op het eerste gezicht moet de peer geloofwaardig zijn voor de doelgroep vanwege de betrouwbaarheid die hij uitstraalt. Op de tweede plaats moet de peer ook geloofwaardig blijven door blijk te geven van voldoende deskundigheid met betrekking tot het onderwerp. Dat kan bereikt worden door scholing, en het kan gestimuleerd worden door de peer voorlichter te laten optreden als vertegenwoordiger van een professionele organisatie. De peer voorlichter zal met betrekking tot de inhoud van de voorlichting ondersteund moeten worden door een professionele organisatie. Daarbij moet met name 
aandacht zijn voor evenwicht in de verschillende rollen die de peer moet vervullen. De geloofwaardigheid door de similariteit mag niet door een té groot accent op deskundigheid, of een té groot accent op de vertegenwoordigde organisatie worden beschadigd.

\subsection{Probleemstelling}

In het proces van intervention mapping moet de keuze voor peer voorlichting gemaakt worden in de (tweede) stap waarbij de methode en de praktische strategie worden bepaald. Op basis van de leer - en veranderdoelen bij een bepaald gezondheidsgedrag wordt de op de theorie gebaseerde methode gekozen. Een combinatie van methodes kan dan een praktische strategie opleveren. Een planmatig proces volgt die stappen in die volgorde, en het is van belang om dat proces als denkmodel vast te houden. In de praktijk loopt het vaak anders omdat er een bepaalde voorlichtingsstructuur beschikbaar is zoals in Rotterdam de groep van peer voorlichters. Om het maar simpel te zeggen: als er een voorlichtingsmedium beschikbaar is, dan is de kans ook groot dat daarvan gebruik wordt gemaakt, ook al zou dat op theoretische gronden niet de beste keuze zijn! Zo zijn de seniorenvoorlichters van de GGD Rotterdam ingeschakeld voor onderwerpen waarbij zij, op theoretische gronden, niet de beste keuze zijn. Dat gebeurde bijvoorbeeld bij voorlichting over de zogenaamde Rotterdam Pas (Een pas waarmee korting op vele culturele Rotterdamse voorzieningen wordt verkregen) waarbij zeker geen bewuste afweging is gemaakt met andere methodes. In dit geval was het niet duidelijk waarom de massamediale voorlichting over die Pas niet beter zou kunnen worden afgestemd op de oudere Rotterdammers. De inzet van de voorlichters roept in die minder vanzelfsprekende situaties veel discussie op, ook bij de voorlichters zelf. Maar die vraagtekens zijn er niet altijd. In het voorbeeld in de inleiding over de migrantenvoorlichtster die diabetesvoorlichting geeft, is nooit overwogen om Turkse diabetespatiënten als peer te gebruiken. De voorlichtster was op veel verschillende onderwerpen al werkzaam in de eerste lijn, en ze is diabetesvoorlichting gaan geven omdat er in de eerste lijn vraag naar was. Pas daarna is er een specifieke interventie ontwikkeld, gekoppeld aan een evaluatieonderzoek (Voorham e.a., 2001). Een bepaalde aanpak kan de gemakkelijkste en meest vanzelfsprekende aanpak worden. De kritische terugkoppeling over effectiviteit door middel van evaluatieonderzoek is dus juist in deze praktische settings van groot belang.

\subsubsection{Een praktische strategie}

Peer voorlichting, ofwel het inschakelen van de doelgroep bij de uitvoering van de voorlichting is volgens de theorie in potentie een effectieve methode. Die effectiviteit is echter niet vanzelfsprekend. Er is een risico dat de planmatige benadering van het gezondheidsprobleem minder nadruk krijgt. Dat gevaar is des te groter omdat er zeer veel keuzes gemaakt moeten worden binnen de methode van peer voorlichting voordat er sprake kan zijn van een effectieve praktische strategie. In het volledige spectrum van de peer methode (van lotgenotencontact tot 'lay health advisors') zitten de migrantenvoorlichters en -sters, en de seniorenvoorlichters erg dicht tegen de 'leken voorlichters' 
of paraprofessionals aan. Er is sprake van een uitgebreide training, van een ondersteuningsstructuur, en van een aanstelling bij een professionele organisatie. Dat laatste meestal vanwege wettelijke verplichtingen, en niet op basis van strategische overwegingen. De concrete vormgeving van de peer methode in een volledige strategie in de concrete situatie, heeft dat met zich meegenomen. Het gevolg is dat de praktijk steeds verder weg is komen staan van een 'zuiver' peerschap, en dus verder weg van de ideale peer. In de evaluatie moet daarom veel aandacht zijn voor de effectiviteit van de inzet, en de vraag of het 'peerschap' daar nog voldoende tot zijn recht komt. In de vertaling naar een praktische strategie kan rekening worden gehouden met de volgende vragen, en tegelijkertijd is het onmogelijk om in projecten op al deze aspecten te variëren. Er worden in dat proces veel pragmatische keuzen gemaakt.

Wie kan de peer voorlichter voor dit onderwerp in deze context zijn? Waaruit bestaat het peerschap? Wat is de bindende factor? Het moet een persoon zijn die in de betreffende context met het onderwerp een wijgevoel bij de doelgroep kan bewerkstelligen, en tegelijkertijd als persoon een rolmodel kan zijn. Hoeveel scholing en training krijgt de peer voorlichter? Er moet een balans gevonden worden tussen de geloofwaardigheid door betrouwbaarheid (de goede vriend) en geloofwaardigheid door deskundigheid (de expert). De geloofwaardigheid door betrouwbaarheid kan als selectiecriterium een rol spelen. De geloofwaardigheid door deskundigheid (Niet alleen inhoudelijk deskundigheid, maar ook groepsprocesvaardigheden!) kan in scholing en training vorm krijgen. Daarnaast kan in de 'marketing' van het product peer voorlichting aandacht zijn voor de organisatie die de voorlichting organiseert. Moet de peer zijn gedrag aanpassen? Of zijn kleding of taalgebruik? In de ondersteuning van de peer voorlichters spelen deze discussies over de té moderne kleding, of juist over het dragen van een hoofddoek. Belangrijk is hier dat de peer voorlichter authentiek blijft, 'echt' blijft overkomen. Ook spelen keuzes over specifiek voorlichtingsgedrag. Wat kun je ter sprake brengen? Hoever kun je gaan met een taboeonderwerp? Is een condoomdemonstratie haalbaar en nuttig? Verder spelen nog keuzes met betrekking tot de zelfstandigheid van de peer, de vorm van de voorlichting, en vele praktische zaken zoals de relatie met de 'ontvangende' organisatie (bijvoorbeeld buurthuis, gezondheidscentrum), wel of geen aanstelling bij de opdrachtgevende organisatie (Is dat bevorderend of belemmerend voor de effectiviteit?), de betaling (Kan dat ook de geloofwaardigheid aantasten? Is het praktisch haalbaar zonder betaling?), de ondersteuning, etc. En tijdens de uitvoering van de voorlichting gelden de volgende vragen. Komen de voorlichtingsdoelen nog voldoende tot uitdrukking? Gaat de culturele vertaling van de boodschap ten koste van de kwaliteit? Migrantenvoorlichters vinden de Nederlandse manier van gezondheidsvoorlichting vaak veel te voorzichtig. 'Je moet de mensen flink bang maken, dan doen ze wel wat je zegtl' De kwaliteitsbewaking is bij de peer voorlichting en in het bijzonder de migrantenvoorlichting van groot belang. Een belangrijke randvoorwaarde voor de kwaliteit van de inzet van peer voorlichters is een inhoudelijke maar vooral ook persoonlijke ondersteuning. Organisaties die peer voorlichters gebruiken moeten juist in de persoonlijke ondersteuning veel investeren. De basis van de peer methode is op de eerste plaats 
het vertrouwen in de peer dat hij of zij het beste weet hoe de doelgroep kan worden bereikt. Zeker is dat in de praktijk van de grote stad met vele verschillende doelgroepen met verschillende achtergronden de hoogopgeleide professional die doelgroep niet meer kan bereiken. De peer voorlichter kan daarbij een brug zijn, maar die brug moet goed worden ondersteund.

\subsubsection{Drie projecten}

In dit proefschrift worden in drie verschillende voor-en-door projecten in de praktijk van de gezondheids-bevordering de volgende vragen beantwoord:

- Is de voor-en-door methode effectief?

- Levert het peerschap daaraan wel of geen bijdrage?

In Schema B worden de kenmerken van de drie projecten met de onderzoeksvragen weergegeven.

\section{Project 1. Gezondheidsvoorlichting voor-en-door ouderen}

De GGD van Rotterdam is gestart met gezondheidsvoorlichting voor ouderen omdat organisaties voor ouderen de GGD regelmatig verzochten gezondheidsvoorlichting voor hun doelgroep te organiseren. Omdat er positieve ervaringen waren met de vooren-door methode voor migranten, en om te kunnen voldoen aan die groeiende vraag, is gestart met de voor-en-door methode voor ouderen. Een eerste groep van ouderen werd geschoold tot seniorenvoorlichter door de Hogeschool Rotterdam e.o. (Kemme, 1992). Op basis van een subsidie van de Commissie Determinanten van Gezondheid van het Ministerie van Volksgezondheid, Welzijn en Sport kon er een evaluatieonderzoek worden uitgevoerd naar de effectiviteit van de seniorenvoorlichting. Voor dit evaluatieonderzoek werd het programma 'Succesvol ouder worden' gekozen zoals dat werd uitgevoerd in Ridderkerk. In dat programma worden ouderen in Ridderkerk in een buurthuis uitgenodigd mee te doen aan een serie van vier gemengde groepsbijeenkomsten. Het doel van het programma is de verbetering van het subjectief welbevinden door de subjectieve sociale steun en de sociale participatie te verbeteren. In de effectevaluatie wordt nagegaan of de voorlichting effectief is: een experimentele groep wordt vergeleken met een groep die op een wachtijist staat. In het procesonderzoek wordt alleen bij de experimentele groep - nagegaan of de voorlichter wordt ervaren als een peer, of die ervaring wel of niet bijdraagt aan de effectiviteit, en of seksehomogeniteit (van voorlichter en deelnemer) voordelig is voor de effectiviteit.

\section{Project 2. Aidsvoorlichting voor en door Turkse en Marokkaanse mannen}

Het eerste voor-en-door project van de GGD van Rotterdam is de migrantenvoorlichting voor en door Turkse en Marokkaanse vrouwen geweest. Op het moment dat ook voor de migrantendoelgroepen aidsvoorlichting moest worden gepland, bleek het ondenkbaar de vrouwelijke voorlichtsters voor mannengroepen aidsvoorlichting zouden geven. Daarom werden specifiek voor dat doel ook Turkse en Marokkaanse mannen getraind. 
Op dat moment coördineerde de GGD deze aanpak voor heel Nederland, met een accent op de vier grote steden. In de uitvoering van deze aanpak kwam een groot accent te liggen op de voorlichtingsactiviteiten in de zogenaamde koffiehuizen voor Turken en Marokkanen. De koffiehuizen zijn een belangrijke vindplaats voor de Turkse en Marokkaanse mannen. In 1996 kon gestart worden met de effectevaluatie van deze koffiehuisvoorlichtingen op basis van een subsidie van het Aidsfonds. De eerste onderzoeksvraag daarbij is of de voorlichting effectief is. Vanwege het taboekarakter van het onderwerp is in het procesonderzoek nagegaan of er sprake is van 'besmetting' van de voorlichter door het onderwerp van de voorlichting. Ofwel, tast het onderwerp Aids het peerschap aan?

\section{Project 3. Diabetesvoorlichting voor Turkse diabetespatiënten}

Relatief recent is de inzet van migrantenvoorlichters in de eerstelijns gezondheidszorg. De voorlichters kunnen door de huisarts en de patiënt worden gevraagd in een driegesprek waarbij de voorlichter helpt met de taal en naar beide partijen toelichting kan geven. De voorlichter kan op een eigen spreekuur persoonlijke voorlichting en consultatie geven. En ten slotte kan de voorlichter groepsvoorlichtingsbijeenkomsten organiseren. In de eerste fase van de inzet van de migrantenvoorlichtsters in een aantal gezondheidscentra bleek diabetes mellitus (DM-2) een belangrijk onderwerp. Op basis van een subsidie van de Commissie Sociaal-economische Gezondheidsverschillen van het Ministerie van Volksgezondheid, Welzijn en Sport kon er een onderzoek worden uitgevoerd naar de effectiviteit van de voorlichting over diabetes. Bovendien is in het procesonderzoek nagegaan of men de voorlichter als peer ervaart, en of er een verschil is tussen mannen en vrouwen. 


\begin{tabular}{|c|c|c|c|}
\hline $\begin{array}{l}\text { Kenmerken } \\
\text { Onderwerp }\end{array}$ & $\begin{array}{l}\text { Project 1: } \\
\text { Succesvol ouder worden }\end{array}$ & $\begin{array}{l}\text { Project 2: } \\
\text { Aids }\end{array}$ & $\begin{array}{l}\text { Project 3: } \\
\text { Diabetes }\end{array}$ \\
\hline Doelgroep & $\begin{array}{l}\text { Ouderen in Ridderkerk, } \\
\text { mannen en vrouwen }\end{array}$ & $\begin{array}{l}\text { Turkse en } \\
\text { Marokkaanse } \\
\text { mannen. }\end{array}$ & $\begin{array}{l}\text { Turkse diabetes: } \\
\text { patiénten, } \\
\text { mannen en vrouwen. }\end{array}$ \\
\hline Similariteit & $\begin{array}{l}\text { Leeftijd: ouderen voor } \\
\text { ouderen. }\end{array}$ & $\begin{array}{l}\text { Elniciteit en migrant zijn: } \\
\text { Turkse en Marokkaanse } \\
\text { mannen voor mannen. }\end{array}$ & $\begin{array}{l}\text { Etniciteit en migrant zijn: } \\
\text { een Turkse voorlichtster: } \\
\text { voor Turkse diabetes- } \\
\text { patiënten. }\end{array}$ \\
\hline $\begin{array}{l}\text { Zwakte in de } \\
\text { similariteit }\end{array}$ & $\begin{array}{l}\text { Mannen en vrouwen } \\
\text { gemengd. }\end{array}$ & Jong en oud gemengd. & $\begin{array}{l}\text { Voorlichtster is zelf } \\
\text { geeen patient; } \\
\text { mannen en vrouwen } \\
\text { gemengd. }\end{array}$ \\
\hline Context & Buurthuis voor ouderen & Koffiehuis & Gezondheidscentrum \\
\hline $\begin{array}{l}\text { Doel van de } \\
\text { voorlichting }\end{array}$ & $\begin{array}{l}\text { Verbeteren van het } \\
\text { subjectief welbevinden. }\end{array}$ & $\begin{array}{l}\text { Verbeteren van mis- } \\
\text { verstanden, barrieres, } \\
\text { persoonlike effectiviteit } \\
\text { en intentie tot condoom- } \\
\text { gebruik. }\end{array}$ & $\begin{array}{l}\text { Gedragsverandering met } \\
\text { betrekking tot voeding, } \\
\text { bewegen en medicijn- } \\
\text { gebruik in relatie tot } \\
\text { diabetes. }\end{array}$ \\
\hline $\begin{array}{l}\text { Vorm van de } \\
\text { voorlichting }\end{array}$ & $\begin{array}{l}\text { Groepsbijeenkomsten: } \\
\text { op uitnodiging, enigszins } \\
\text { formeel. }\end{array}$ & $\begin{array}{l}\text { Koffiehuisvoorlichtingen: } \\
\text { ad hoc georganiseerde } \\
\text { bijeenkomst. }\end{array}$ & $\begin{array}{l}\text { Driegesprekken met arts, } \\
\text { individuele begeleiding } \\
\text { en groepsbijeenkomsten. }\end{array}$ \\
\hline $\begin{array}{l}\text { Rol van de } \\
\text { voorlichter }\end{array}$ & $\begin{array}{l}\text { De voorlichter doet } \\
\text { een expliciet beroep op } \\
\text { een wigevoel als ouderen } \\
\text { onderling. }\end{array}$ & $\begin{array}{l}\text { Afhankelijk van het publiek } \\
\text { doet de voorlichter expliciet } \\
\text { een beroep op gemeen- } \\
\text { schappelijke etniciteit en } \\
\text { migranten zijn. }\end{array}$ & $\begin{array}{l}\text { De voorlichtster stelt zich } \\
\text { op de eerste plaats op als } \\
\text { intermediair die kan hel- } \\
\text { pen met de taal; op de } \\
\text { iweede plaats als Turkse } \\
\text { migrant. }\end{array}$ \\
\hline $\begin{array}{l}\text { Gedrag in } \\
\text { relatie tot het } \\
\text { doel }\end{array}$ & $\begin{array}{l}\text { De voorlichter spreekt } \\
\text { vanuit haar eigen } \\
\text { ervaring van het ouder } \\
\text { worden. }\end{array}$ & $\begin{array}{l}\text { De voorlichter moet kiezen } \\
\text { om welgeen condoom- } \\
\text { demonstratie te geven, } \\
\text { wellgeen bedekte termen } \\
\text { te gebruiken. }\end{array}$ & $\begin{array}{l}\text { De voorlichtster kan rond } \\
\text { voedingsadviezen, maar } \\
\text { niet rond overgewicht } \\
\text { vanuit elgen ervaring } \\
\text { praten. }\end{array}$ \\
\hline $\begin{array}{l}\text { Organisatiel } \\
\text { Opdrachtgever }\end{array}$ & $\begin{array}{l}\text { GGD/ Stichting Welzijn } \\
\text { Ouderen Ridderkerk }\end{array}$ & $\begin{array}{l}\text { GGD: de voorlichter } \\
\text { presenteert zich expliciet } \\
\text { als GGD-medewerker. }\end{array}$ & $\begin{array}{l}\text { Gezondheidscentrum/ } \\
\text { GGD }\end{array}$ \\
\hline $\begin{array}{l}\text { Onderzoeks- } \\
\text { vraag effect }\end{array}$ & $\begin{array}{l}\text { Is de voorlichting over } \\
\text { succesvol ouder worden } \\
\text { effectief? }\end{array}$ & $\begin{array}{l}\text { Is de voorlichting over } \\
\text { Aids effectief? }\end{array}$ & $\begin{array}{l}\text { Is de begeleiding } \\
\text { van de voorlichtster } \\
\text { effectief? }\end{array}$ \\
\hline $\begin{array}{l}\text { Onderzoeks: } \\
\text { vraag proces }\end{array}$ & $\begin{array}{l}\text { Wordt de voorlichter door } \\
\text { de doeigroep ervaren } \\
\text { als peer voorichter? } \\
\text { is er een relatie tussen } \\
\text { die ervaring van de doel- } \\
\text { groep en de effectiviteit } \\
\text { van de voorlichting? } \\
\text { Is seksehomogeniteit } \\
\text { (mannen voor mannen, } \\
\text { vrouwen voor vrouwen) } \\
\text { voordelig voor de } \\
\text { effectiviteit? }\end{array}$ & $\begin{array}{l}\text { Wordt de voorlichter } \\
\text { door de doelgroep } \\
\text { ervaren als peer- } \\
\text { voorlichter? } \\
\text { Is het taboe-onderwerp } \\
\text { en een condoom- } \\
\text { demonstratie een } \\
\text { bedreiging voor het } \\
\text { peerschap? }\end{array}$ & $\begin{array}{l}\text { Wordt de voorlichter door } \\
\text { de doelgroep ervaren } \\
\text { ais peer voorlichter? } \\
\text { is er een verschil tussen } \\
\text { mannen en vrouwen? } \\
\text { (seksehomogeniteit) }\end{array}$ \\
\hline
\end{tabular}




\section{Literatuur}

Ajzen I. ((1991) The Theory of Planned Behaviour. Organizational Behaviour and Human Decision Processes. 50: 179-211

Arnstein, S. (1969). A ladder of citizen participation. Journal of the American Institute of Planners. July, pp 216-224.

Bandura, A. (1986) Social foundations of thought and action: a social cognitive theory. Englewood Cliffs, NJ: Prentice Hall.

Bartholomew LK, Parcel GS, Kok G, Gottlieb NH. (2001). Intervention Mapping: designing theory and evidence-based health promotion programs. Mayfield Publishing Company, Mountain View, California.

Backett-Milburn, K., Wilson, S. (2000). Understanding peer education; insights from a process evaluation. Health Education Research. 15. 85-96.

Buunk A.P. (1992) De zilveren medaille van de sociale vergelijking. Inaugurele rede 22 oktober 1991, RU Groningen, Wolters-Noordhoff Groningen

Buunk A.P. F.X. Gibbons (eds) (1997) Health, coping and weel-being: perspectives from social comparison theory. Lawrence Erlbaum Ass., New York.

Buunk A.P., F.X. Gibbons, M. Reis-Bergan (1997) Social comparison in health and illness: a historical overview. In: Buunk B. P. F.X. Gibbons (eds) (1997) Health, coping and weelbeing: perspectives from social comparison theory. Lawrence Erlbaum Ass., New York: $1-25$

Brug J., Schaalma H., Kok G., Meertens R.M., van der Molen H.T. (2000)

Gezondheidsvoorlichting en gedragsverandering. Een planmatige aanpak. Assen: Van Gorkum.

Butte, D. (1996). Over de grens! Verslag over opzet en uitvoering van een pilotproject primaire preventie van seksueel geweld. GGD Rotterdam.

Crul, M. (2001). Leerlingbegeleiding in het voortgezet onderwijs door Turkse en Marokkaanse studenten. Amsterdam: Het Spinhuis.

Dugardyn, R. (1996). Peer educators zijn geen verlengstuk van de voorlichter. TGV Tijdschrift Gezondheidsvoorlichting 13, 8-9.

Earp J.A.L., Viadro C.I., Vincus A.A. (et al.). (1997). Lay health advisors: a strategy for getting the word out about breast cancer. Health Education \& Behavior 24, 432-451.

Eng, E., Parker, E., Harlan, C. (1997), Lay health advisors intervention strategies: a continuum from nature helping to paraprofessional helping. Health Education \& Behaviour 24, 413-417.

Festinger, L. (1954). A theory of social comparison processes. Human Relations: 7; 117-140. 
Frankham, J. (1998). Peer education: the unauthorised version. British Educational Research Journal 24, 179-191.

Freire P. (1976). Pedagogie van de onderdrukten. Baarn: Anthos

Freire P. (1985). The politics of education. Massachusetts: Bergin and Garvey Publishers.

Gelauff-Hanzon, C., Keune, C., Tan, S. (1999) . Paraprofessionals: pioniers of pionnen? Een onderzoek naar de voorwaarden van een optimale inzet. Verwey-Jonker Instituut, Utrecht.

Goddijn H.P.M., Thoenes P. de Valk J.M.M., Verhoogt J.P. (1974). Geschiedenis van de sociologie. Derde druk. Meppel, Boom: p. 221.

Goumans, M. (1998). Innovations in a fuzzy domain. Healthy Cities and (Health) Policy development in the Netherlands and the United Kingdom. Proefschrift Maastricht.

Green, J. (2001) Peer education. Promotion \& Education, Quarterly of the IUHPE, Vol. 8; no 2; pp. 65-68.

Kemme, G. (1992). Uitgangspunten voor het lesprogramma van de kadercursus gezondheidsvoorlichting voor en door ouderen, Hogeschool Rotterdam \& Omgeving (Interne notitie).

Kemme, G. (1995). Effectiever voorlichten: de voor en door methode. Lemma, Utrecht.

Kocken P.L. (2000) Health promotion in migrants and older adults. Epidemiological diagnosis, intervention development and effect evaluation. Proefschrift Maastricht.

Kocken P.L., Voorham A.J.J. , Brandsma J., Swart W.A.J.M. (2001) Effects of peer-led Aids education aimed at Turkish and Moroccan male migrants in the Netherlands: a randomized controlled evaluation study. European Journal of Public health; 11, 2: 153-159.

Kocken P.L., Wouter L., Voorham A.J.J., de Zwart O. (2002). Amor i Salú. Het Rotterdamse communityproject ter bevordering van de seksuele gezondheid van Antillianen en Arubanen. GGD Rotterdam.

Lieburg, M.J. van. (1989). Woord en boek in de geschiedenis van de geneeskunde. Een beschouwing over de toegankelijkheid van medische kennis, Atlanta Amsterdam (Inaugurele rede, Erasmus universiteit, 6 okt 1988).

Lieburg, M.J. van, Snelders, H.A.M. (1989). "De bevordering en volmaking van de proefondervindelijke wijsbegeerte". De rol van het Bataafsch Genootschap te Rotterdam in de geschiedenis van de natuurwetenschappen, de geneeskunde en de techniek (1769-1988). Atlanta Amsterdam.

McGuire, W.J. (1985). Attitudes and attitude change. In G. Lindzey \& E. Aronson (eds.), The handbook of social psychology (vol. 2) (pp. 233-246). New York: Random House.

Mead G.H. (1972). Mind, Self \& Society from the standpoint of a Social Behaviorist. $18 \mathrm{e}$ ed. Chicago, University of Chicago Press: p. 254 e.v. 
Meertens, R.W., Grumbkow, J. von. (red.) (1992). Sociale Psychologie. Groningen: WoltersNoordhoff. Heerlen: Open Universiteit.

Meertens R., Schaalma H., Brug J., de Vries N. (2000) Determinanten van gedrag. In: Brug J., Schaalma H., Kok G., Meertens R.M., Van der Molen H.T. Gezondheidsvoorlichting en gedragsverandering. Een planmatige aanpak. Assen: Van Gorcum \& Comp.

Mellanby, A.R., Rees, J.B., Tripp, J.H. (2000). Peer-led and adult-led school education: a critical review of available comparative research. Health Education Research, 15, 533-545.

Milburn K. (1995) A critical review of peer education with young people with special reference to sexual health. Health Education Research, 10, 4: 407-420.

Misovich S.J., J.D. Fischer, W.A. Fischer (1997) Social comparison processes and Aids riskd and Aids preventive behavior. In: Buunk B. P., F.X. Gibbons (eds) (1997) Health, coping and well-being: perspectives from social comparison theory. Lawrence Eribaum Ass., New York: $95-125$

NIGZ (Nederlands Instituut voor Gezondheidsbevordering en Ziektepreventie) (1998) Tien jaar voorlichting in de eigen taal en cultuur over gezondheid en opvoeding. Woerden: NIGZ.

Nutbeam D., Harris E. (1998). Theory in a nutshell. A practitioner's guide to commonly used theories and models in health promotion. Sydney: National Centre for Health promotion, 1998.

Peers I.S., Ledwith F., Johnston M. (1993) Community Youth project HIVIAids. University of Manchester School of Education Report to the Health Education Authority.

Penninx, K., Prinsen, B. (2000). De voor en door methode. Burgers als helpers en voorlichters. NIZW. Utrecht.

Prochaska J.O., DiClimente C.C. (1984) The transtheoretical approach: Crossing traditional boundaries of therapy. Homewood II: Dow Jones Irwin.

Prochaska J.O., Redding C.A., Evers K.E. (1997) The transtheoretical model and stages of change. In: Glanz K., Lewis F.M., Rimer B.K. (eds.) Health behavior and health education: theory, research and practice (pp. 60-84). San Fransisco, CA: Jossey-Bass.

Rogers E.M. (1983) Diffusion of innovations. 3th ed. New York: Free Press

Rothman J., Tropman J.E. (1987) Model of Community Organisation and Macro Practice: Their mixing and phasing. In: Cox F.M., Ehrlich J.L., Rothman J., Tropman J.E., (eds). Strategies of community organsation. 4th edition. Itasca, III: Peacock. 
Service, C., Salber, E. (eds). (1979). Community health education: the lay health advisor approach., Duke University Health Care System, Durham, NC.

Straathof, M. (1999). Paraprofessionals: onmisbaar en onderschat. VWS Bulletin (20 aug) 18-19.

Strecher V.J. Rosenstock I.M. (1997) The Health Belief Model. In: Glanz K., Lewis F.M., Rimer B.K. (eds.) Health behavior and health education: theory, research and practice. San Fransisco, CA: Jossey-Bass.

Tones, K. (1992). Peer teaching: some theoretical insights. TACADE/Health Education Authorithy Conference, London.

Tönnies, F. (1887). Gemeinschaft und Gesellschaft. Grundbegriffe der reinen Soziologie. Darmstadt.

Turner, G., Shepherd, J. (1999). A method in search of a theory: peer education and health promotion. Health Education Research 14, 235-247.

Vries, H. de. (1992). Het voorlichtingsmodel. In: Meertens RW. Grumbkow, J. von (red). Sociale Psychologie, Groningen. Wolters-Noordhoff.

Voorham A.J.J., Reelick N.F. (1986) De rol van procesonderzoek bij een GVO-actie. Tijdschrift gezondheidsbevordering, $7: 4: 17-26$.

Voorham A.J.J. , Uitewaal P.J.M., Bruijnzeels M. (2002) Het effect van voorlichting in de eigen taal aan Turkse diabetespatiënten een experiment in de eerste lijn. TSG/ Tijdschrift voor gezondheidswetenschappen; 80, 8: 514-520.

Voorham A.J.J., Haastrecht, P.M. van. (1996). Gezondheidsbevordering: gekleurde samenleving, motor voor verandering. In: Haveman, H.B., P. Uniken Venema. Migranten en Gezondheidszorg. Bohn Stafleu Van Loghum. Houten/Diegem.

Voorham A.J.J., Uitewaal P.J.M., de Hoop T. (2001) Voorlichting in de eigen taal aan Turkse diabetespatienten. Het effect op bloedsuikerwaarden, de ervaren zorg en gedrag. In : Stronks K. Sociaal-economische gezondheidsverschillen: Van verklaren naar verkleinen. Deel 4. Den Haag: ZonMw.

Voorham A.J.J., Kocken P.L., Brandsma J., van Haastrecht P. (2002) Opvattingen over voorlichting en de voorlichter in de eigen taal bij Turkse en Marokkaanse mannen na voorlichting over Aids. TSG/Tijdschrift voor Gezondheidswetenschappen; 80, 2: 110-114.

Wagemans M., de Zwart O., Sandfort Th. (1998) Sexplain: een peer project over seksuele gezondheid van jongeren. Eindrapportage. Rotterdam: GGD.

Watkins, E.L., Harlan, Ch., Eng, E., Gehan, D., Larson, K. (1994). Assessing the effectiveness of lay health advisors with migrant farm workers. Family \& Community Health 16. $72-87$.

Zijderveld A.C. (1973) De theorie van het symbolisch interactionisme. Meppel: Boom. 



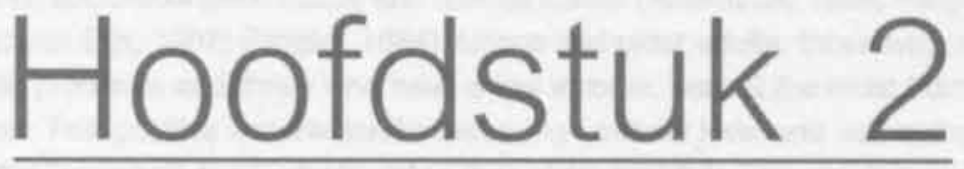

Effect of a peer-led senior health education program 


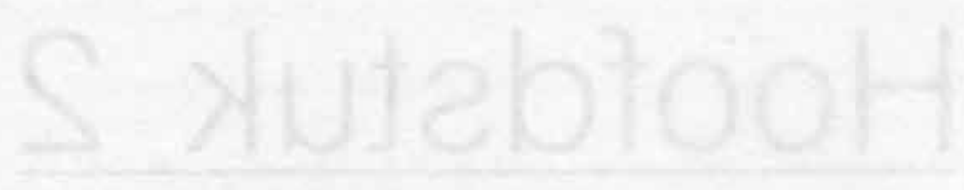

\section{Abstract}

The effect of a health education course guided by peers aged 55 and over was evaluated. The aim of the course was to empower older adults to participate in society and to promote their well-being. Evaluation included determining the effect on attitude toward aging, self-efficacy, perception of the societal opinion regarding the place of the elderly in society (social influence), social participa-tion, perceived social support, and wellbeing of the participants aged 55 to 79 years. A quasi-experimen-tal approach was used. The effect on the experimental group of participants was studied compared to a control group of older adults on the waiting list. The respondents filled out postal questionnaires at three time points (before starting the course ( $(0)$, immedi-ately after termination (t1) and three months later (t2)). Using a multivariate analysis procedure, a significant interaction effect between time of measurement and group membership was found with respect to the outcome of social influence. At $\mathrm{t1}$ an effect was absent, but at $\mathrm{t} 2$, the current idea that elderly occupy a marginal position in society, found less favour with the experi-mental group than the control group. Moreover perceived social support and subjective health improved significantly at $\mathrm{t} 1$ and $\mathrm{t} 2$ among the course members, when compared to the control group. No effect was found on attitude, self-efficacy, social participation and well being in the short time span of a three months follow-up. 


\section{Effect of a peer-led senior health education program}

\subsection{Introduction}

Involvement in activities by older adults is associated with a higher degree of wellbeing. A relationship has been found between engagement in voluntary or leisure a ctivities and subjective well-being in several studies, however this relation-ship is modified by health, socio-economic status and marital status (Adelmann, 1994; Kelly and Ross, 1988; van Eijk, 1997; Fengler, 1984). Unmarried older adults, those who experience health problems and those who have a low income, benefit the most from activity participa-tion. This positive association between high activity level and well-being gives support to the "activity theory" which states that, unless inhibited by physical problems, the needs of older adults in the area of social interaction, are the same as those of young people. Older adults seek to fulfil multiple roles and to keep contact with their social envi-ronment (Havighurst e.a., 1968; Adelmann, 1994). This is the opposite of the "disengage-ment theory" by which elderly people choose to diminish their interaction with the environment. The reduction in attention paid to other people and increase of care for the self is viewed, in this theory, as a natural process (Cumming and Henry, 1961). Continu-ation of social participation can be characte-rized as differential disengage-ment (Atchley, 1976). Elderly people cease their involve-ment in some areas when retiring, while continuing and intensifying their activities in others like leisure time pursuits or grand parenting.

The importance of having social ties is also shown by the beneficial effect of social support on the health and well-being of older people. Longitudinal studies show less mental health problems and mortality among older adults who experience a high availability of adequate social support (Thoits, 1995; Oxman e.a.,1992; Hanson e.a.,1989; Yasuda e.a.,1997). When social support is absent, support groups can function as an alternative to provide older adults with information, emotional support or services. Health education programs which make use of peers have the potential to become a surrogate support system for people in need. Examples include peer-facilitated workshops or support groups where people can exchange their experiences with health problems (Pearson, 1990; Campbell and Chenoweth, 1981).

An evaluation of the effectiveness of the health education course "Successful Aging" is presented in this article. In this course, guided by peers aged 55 years and over, older adults discussed health related topics like memory problems, housing and use of medicines. The course objectives at a more general level were evaluated. The general aim of the course was to promote social participa-tion, social support and wellbeing. Unlike most evaluation research of health education programs, this article does not consider the effect-iveness of the course in achieving health related program targets. This article addresses the following question. Was the course "Successful Aging" effective in improving the determinants of social participation, social participation, social support and 
well-being of its members? The contents, behavioural model and strategies of the course are explained in more detail below.

\subsection{Outline of the course "Successful Aging"}

\subsubsection{Course contents}

The course "Successful Aging" was organized in Ridderkerk, a community in the urban area of Rotterdam. Both the national and local government in the Netherlands support activities that provide older adults with the opportunity to participate in society and to live a meaning-ful life. "Successful Aging" was organized in support of this policy of empowering older adults to stay active. The course was designed to encourage participation in (health promotion) activities, for example, social clubs, exercise programs and memory training. Moreover, the course was aimed at changing participants' behaviour in health risk areas. Changes in behaviour affecting health and social participation were expected to promote the central target of the program: improvement of the social, psychological and physical wellbeing of older adults. The course was facilitated by peers, aged 55 years and over, called senior health educators, who had received intensive training prior to the course. Groups of about 20 older people met each other, once a week, on four occasions. Every meeting consisted of an introduction, given by the senior health educator, of a topic relevant to individuals facing the aging process, followed by a peer facilitated discussion. The first session started with a general introduction. Guided by the senior health educator, determinants of successful aging like social support, healthy life-styles, sufficient income and self-efficacy were considered. The group was free to choose which topics they wanted to discuss at the following three sessions. Every session dealt with one topic and lasted two hours. The following topics were chosen in the six courses that were evaluated:sleeping problems, memory problems, use of medicines, housing of older adults,osteoporosis, physical exercise and growing old in different cultures.

\subsubsection{Behavioural model}

Ajzen's theory of planned behaviour and Bandura's social learning theory were used in the program design (Ajzen, 1991; Bandura, 1986). The program was based on the assumption that social participation is related to three determinants: attitude towards aging, the influence of societal opinion (social influence) regarding the role of the elderly in society, and finally selfefficacy in engaging in new activities (figure 1). It was hypothe-sized that engagement in activities can be determined by a positive or negative attitude towards aging. A positive evaluation of existence as an older person, would have a positive influence on a person's capacity to stay active. The second determinant, social influence, is defined as the processes whereby people, directly or indirectly, influence the thoughts, feelings and actions of others (de Vries e.a.,1995). The course was aimed at the individual's perception of societal opinion. In contrast to the disengagementtheory, it was argued that older adults in general, do not wish to diminish interaction with society. They continue activities and develop new interests to substitute for losses 
caused by the changes brought about by retirement. It was postulated that when people consider themselves to be productive persons who can contribute to society, instead of the prevailing norm that elderly have a little say, they will be inclined to participate in activities. The third determinant, self-efficacy from Bandura's social learning theory, is a powerful determinant of behavioural change. Self-efficacy is similar to perceived behaviou-ral control in the theory of planned behaviour, meaning a person's expectation regarding his capability to realize a desired behaviour (Bandura, 1986; Ajzen and Madden, 1986; Maybach and Murphy, 1995). Studies among older adults indicate that individuals with high selfefficacy are more likely to change their behaviour and experience better physical and mental health (Grembowski e.a.,1993; Abler and Fretz, 1988; Rodin and McAvay, 1992). In the theoretical model presented in this article it is postulated that when an individual's perception of selfefficacy in starting new activities is high, they will more likely be successful in engaging in these activities. Participation in "Successful Aging" in the model is not only connected indirectly to social support and wellbeing through the promotion of social participation and its determinants.

Participation in the course, being an act representing an active life, will also have a direct effect on the perceived social support and wellbeing of its members (figure 1). The behavioural model used in "Successful Aging" and presented in this article was based on hypotheses, which have to be studied more in-depth.

\section{Figure 1. Theoretical model of effect of course participation}

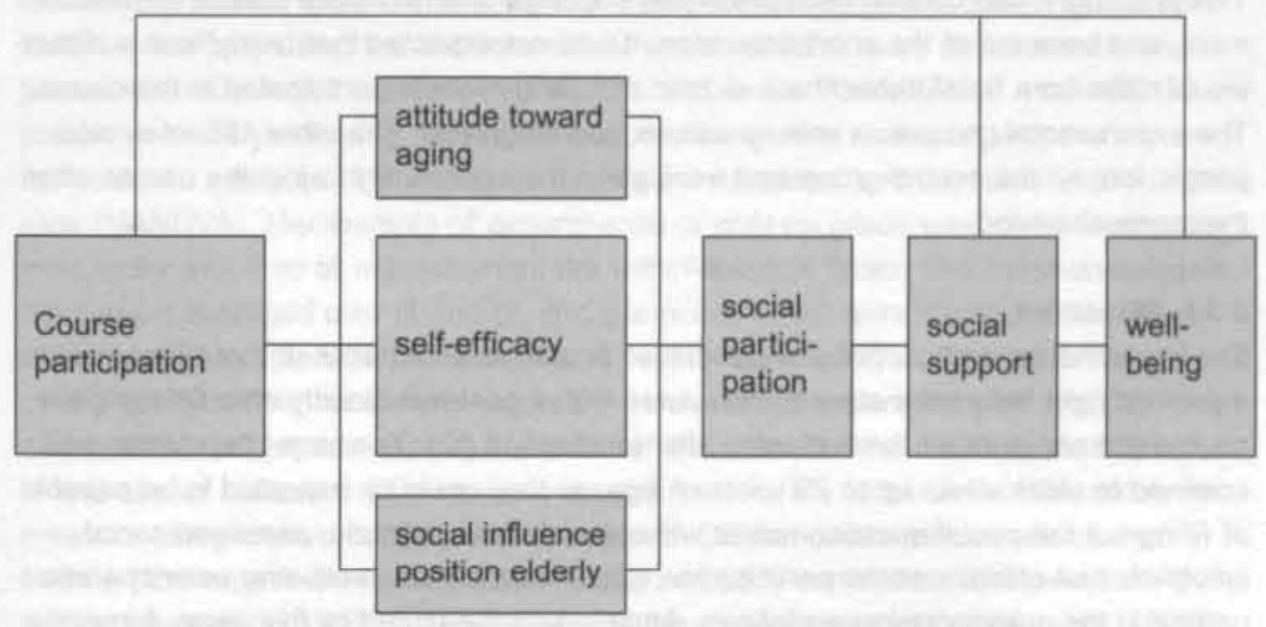

\subsubsection{Course strategies}

Information transfer, role modelling, education by peers and group interaction were strategies used in the course. The senior health educators passed on information to fellow senior citizens about healthy lifestyles. The introduction of health issues was used as a vehicle to discuss repeatedly the three determinants of social participation. For instan$c e$ in a session about forgetfulness, the senior health educator addressed the question of barriers to subscribe for a memory training course, thus the self-efficacy to participa- 
te in memory training became an issue. The senior health educators communicated continuously the message that older people can make an important contribution to society, and opposed the common idea that they play only a marginal role. The educators served as role models, representing older adults who still have a say. They fulfil the policy target of social participation and function as an example for successfully living an indepen-dent and active life. Use of peers enhances the credibility of the informa-tion given by the health educator (Rogers, 1983). It was expected that communication using peer educators, who were close in age, beliefs, and social status, to the target population, would be more effective. Finally, course members learned from each other, during the discussions and group interaction sessions, where informa-tion and experiences were exchanged, and social support was available.

\subsection{Method}

All independent living older adults, aged 55 to 79 years, in the community of Ridderkerk were invited by direct mail to partici-pate. A more detailed explanation of this procedure is discussed in a seperate paper on characteristics of people interested in participation in the course "Successful Aging" (Kocken and Voorham, 1998). At the start of the course, 320 individuals were interested in participation. Later more people subscribed to the course, but they were excluded from the evaluation research. In the order in which the applications were received, 150 individuals were assigned to the experimental group. This procedure was chosen because of the shortage of time before course commencement, and because of the short time-span, it was not expected that "early" sub-scribers would differ from "late" subscribers. A total of 138 applicants participated in the course. The experimental group was split up into six course groups. The other 182 interested people formed the control group and were given the opportunity to join the course after the research period.

\subsubsection{Measures}

The experimental and control group received postal questionnaires at three time points: a pre-test right before the start of the course (t0), a post-test directly after finishing the course ( $t 1$ ) and another three months after termination ( $t 2)$. The target population was confined to older adults up to 79 years of age, as they could be expected to be capable of filling out the postal question-naires without prob-lems. Attitude, perceived social influence, self-efficacy, social participation, social support and wellbeing were operationalized in the questionnaires as follows. Attitude was measured by five items, forming a scale of nega-tive and positive opinions about growing older, for example "as an older adult one feels that every day is the same" $(\alpha=0.64)$. Perception of the societal opinion on the position of elderly in society was measured by one item: "older adults have a too little say". Self-efficacy in starting new activities was measured using the Dutch version of the validated general self-efficacy scale (Sherer and Maddox, 1982; Bosscher e.a.,1992). This scale measures self-efficacy expectations across a variety of situations and consists of two components: initiation and per-sistence of behaviour, and efficacy 
in the face of adversity. The scale consists of 16 items, e.g. "when I decide to do something, I go right to work on it" ( $\alpha=0.8-3$ ). Social participation was measured by having the respondents rate the number of hours per week spent recently on hobbies and activities with other people, outside the home. This question was not asked at $\mathrm{t} 1$ because of the possible interference of course participation. Social support was measured using the validated scale of perceived everyday support, consisting of ten items like "do you feel that attention is being paid to you?" ( $\alpha=0.88)$ (Sonderen, 1991). Wellbeing was measured using a short version of the validated Dutch scale for wellbeing of the elderly ( 8 items) (Linschoten e.a.,1993). The scale measures negative and positive feelings, experien-ced by the respondent, e.g. "on the whole I am satisfied with myself" ( $\alpha=0.81$ ). Subjective health was assessed by answering a question in which respon-dents could rate their health from 1 (very bad) to 10 (very good).

Some sociodemographic characteristics were asked in the questionnaire at t0: gender, age, marital status and level of last occupation. Physical functioning was measured using the 6-item sub-scale of the MOS Shortform General Health Survey (MOS-20) $(\alpha=0.86)$ (Steward and Ware, 1992; Kempen, 1992a and 1992b). Data were also gathered concerning locus of control ("to what extent can you influence your own health?") and life-events ("have there been radical changes in your life the last few years?").

\subsubsection{Analysis}

The response rates of the experimental and control group were established.

Differences in back-ground characteristics in the experimental and control group were tested statistically using the Chi-square test when variables were dichotomous, and Mantel-Haenszel test for linear trend when trichotomous. The effect of attending the course was analysed using repeated measures analysis of variance, with the scores of the outcome measure at $\mathrm{t} 1$ and $\mathrm{t} 2$ as dependent variables, and the score at to as covariate (MANOVA). Membership of experimental or cont-rol group was the between-subjects factor and time of measurement the within-subjects factor. The between-subjects main effect averaged over $\mathrm{t} 1$ and $\mathrm{t} 2$, and interaction effect were studied. When there was a significant interaction effect $(p<0.10)$, mean scale scores of the experimental and control group on the outcome measures were assessed separately at $t 1$ and $t 2$. When an interaction effect was absent, the mean of the scores of the outcome measure at $\mathrm{t} 1$ and $\mathrm{t} 2$ was assessed. The scores were adjusted for the initial level of the outcome measure using multivariate regression analysis. Differences in mean scale scores between the experimen-tal and control group and 95\%-confidence intervals (95\%-C.I.'s) were assessed. SPSS/PC+ 5.0 was used in the analysis procedures (Norusis, 1992).

\subsection{Results}

\subsubsection{Response}

The response rates of people filling out the questionnaire at all three time points were $51 \%$ for the experimental group, and $41 \%$ for the control group. Gender, age 
and marital status of the response groups did not differ from the originally selected experimental and control group. The experimental and control group did not differ significantly in background characteristics (Table 1). Neither did they differ with respect to the initial scores of the outcome variables at to (Table 2). These results agree with the assumption that the experimental group ("early" subscribers) did not differ from the control group.

\begin{tabular}{llll}
$\begin{array}{l}\text { Table 1. Background characteristics of experimental }(n=71) \\
\text { Experimental }\end{array}$ & $\begin{array}{r}\text { and control group }(n=75) \\
\text { Control group } \\
\%\end{array}$ \\
\hline Gender & male & 37 & 39 \\
& female & 63 & 61 \\
Age & $55-64$ & 52 & 43 \\
& $65-74$ & 32 & 47 \\
Marital status & $75-79$ & 16 & 11 \\
& married & 55 & 65 \\
Radical changes in & unmarried & 45 & 35 \\
life the last few years & no/few & 37 & 43 \\
& moderate/many & 63 & 57 \\
Extent to which one & & & 85 \\
can influence one's own health & internal & 78 & 15 \\
Physical limitations & external & 22 & 28 \\
& many & 37 & 31 \\
& moderateffew & 32 & 41 \\
Socio-economic & no & 31 & 45 \\
status (occupational level) & low & 33 & 34 \\
& moderate & 32 & 21
\end{tabular}

\subsubsection{Effectiveness}

The crude, unadjusted, outcome scores of the pre-test and post-tests are given in Table 2. A significant difference of mean scores between the experimental and control group was only found for the outcome of social influence at 12 . A multivariate repeated measures analysis (MANO-VA) was used to determine the effect of the course, taking into account the initial level of the outcome variable in the pre-test. Interaction between treatment (course membership) and time of measurement was found for the outcome of social influence $(F=9.74, p<0.01)$. The effect was therefore analysed separately at each time point, however, because of the almost equal pre-test scores of the experimental and control group, the multivariate analysis did not change the results of the crude scores at bivariate level. At $\mathrm{t} 1$ immediately after course termination the respondents did not differ signifi-cantly with respect to their perception of the societal opinion regarding the position of elderly in society (table 2). After three months (t2) the experimental group compared to the control group disagreed significantly more with the opinion that elderly have little say (difference in adjusted mean scores of 0.55 (95\%-C.I. $0.13-0.96$ ). In the repeated measures MANOVA no significant interaction between treat- 
ment and time of measure-ment was found for the other outcome measures. The adjusted scores on the post-tests at $\mathrm{t} 1$ and $\mathrm{t} 2$ are therefore presented in table 2 as group means of the single scores averaged over $t 1$ and $t 2$. An effect on attitude towards aging and self-efficacy still was absent, when the pre-test scores of the experimental and control group were taken into consideration. The difference between the experimental and control group in time spent on hobbies and activities with other people outside the home, as an indication of social participation, three months after course termination was also not significant. The course had an effect on the perception of everyday social support among its members (a difference in mean averaged scores at $\mathrm{t} 1$ and $\mathrm{t} 2$ of $0.98 ; 95 \%$-C.I. $0.05-1.91$ ). The scores of the course members increased from pre-test to post-tests, while the scores of the control group decreased. An effect on general wellbeing was absent, but a clear effect was found on the rating of participants of their subjective health. The course members gave their health at $\mathrm{t} 1$ and $\mathrm{t} 2 \mathrm{a}$ mean averaged score of 7.55 , while the score of the control group was 7.18 (difference in mean averaged scores of $0.37 ; 95 \%-C . I .0 .11-0.63)$ ). Again a rise in mean scores among the course members could be observed against a fall in the control group. When multiple testing was taken into account $(p<0.01$ instead of 0.05 ), the effect on subjective health remained significant at a $99 \%$-confidence interval ( $99 \%$-C.I. of mean averaged scores at $t 1$ and $t 2: 0.02-0.72$ ). The effect on perceived social influence at t2 was lost ( $99 \%$-C.I. $-0.01-1.10)$. The effect on social support was also no longer significant (99\%-C.I. of mean averaged scores at $\mathrm{t} 1$ and $\mathrm{t} 2$ : $-0.25-2.21)$.

\subsection{Discussion}

The effectiveness of the peer-led health education course "Successful Aging" was evaluated with regard to the following outcome measures: attitude towards aging. perceived social influence, generalized self-efficacy, social participation, social support and well being. Although joining the course is already an act of active aging, assessment of the impact of the course on determinants of participation is relevant in view of the policy aim of motivating older people to become more active. The course is thought to have encouraged people to engage in new (health promotion) activities which should result in an improvement in well being.

This evaluation showed an effect on several outcome measures, however the effect size was small. The course "Successful Aging" had an effect on the opinion of participants regarding the position of elderly. The experimental group, three months after course termination, showed less agreement with the current societal view (social influence) that "elderly have a too little say in society" when compared to the control group. Social learning theory indicates that modelling can be viewed as exerting indirect social influence (Bandura, 1986; de Vries e.a., 1988). Education by peers, who act as role models for living an active life, will have contributed to the effect of the importance attached to the elderly. A significant effect on attitude towards aging and generalized self-efficacy could not be found. The course strategies used in the course, consisting of only four sessions, were presumably not powerful enough to accomplish an effect. Another explanation may be a "ceiling-effect". Participants (and control group) were 
prepared to join the course, so their initial scores on the outcome measures were already high. Lack of results might also be due to the general nature of the scales used. For instance, the scale used to measure self-efficacy may not have been sensitive enough to monitor the intended change (Maibach and Murphy, 1995).

Table 2. Effect of the course: crude and adjusted mean scale-scores and difference in mean scores between experimen-tal and control group (95\%-confidence intervals).

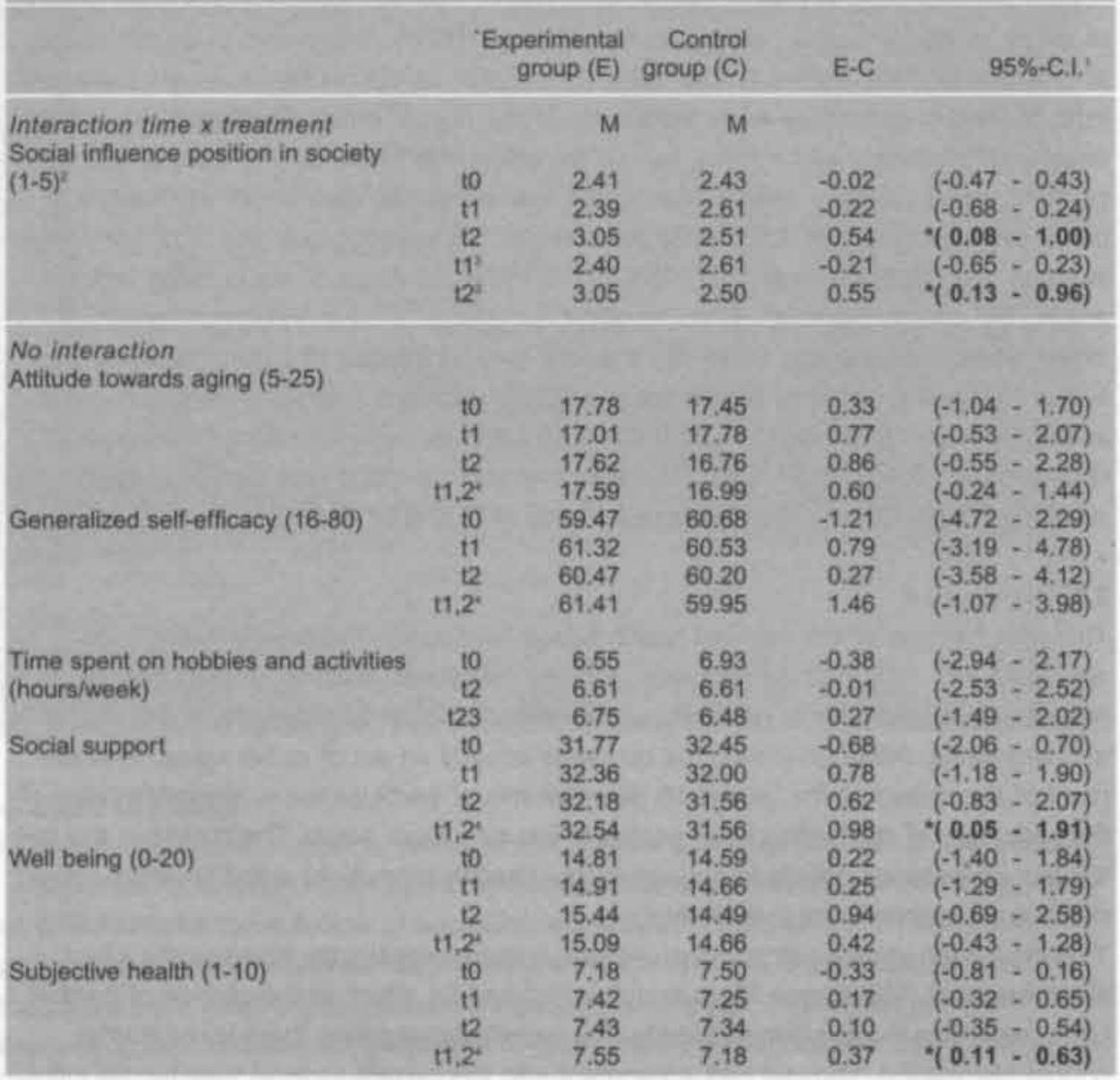

$195 \%$-confidence interval

2 scale range

3 values of the outcome va-riables have been adjusted for the initial level at to.

4 values of the outcome va-riables at $t 1$ and 12 have been averaged and adjusted for the initial level at to.

- confidence interval does not contain value 0 .

The limited effect on the determinants of social participation did not result in a change of activity level, as can be expected from the theoretical model presented in this article (Figure 1). The time spent on activities and hobbies with other people outside the home 
among the experimental and control group did not differ significantly. The course members did not increase engagement in activities that were promoted by the senior health educators, like physical exercise programs, and courses in the field of memory training or dealing with sleeping problems. It should be mentioned that the follow up period during which people could take up activities was very short. Moreover, the follow up took place during the summer vacation period, when many social activities stop in the Netherlands.

The course did achieve an effect on the perception of the daily social support available from the environ-ment. Participation in the course group had influenced social support directly. The group served as a substitute support system for individuals who lacked sufficient informative and emotional support, and because the effect was maintained after three months, the expectations of the social support available in the environment will also have been changed. An indirect influence of course attendance on social support as described in the theoretical model is not plausible because of the absence of an effect on social participation.

The change of perceived social support did not result in an improvement of well-being measured by a comprehensive scale, however an effect on the more limited measure of subjective health was present. Directly after finishing the course, and after a lapse of three months, the subjective health valuation of participants changed in a favourable way. The effect on subjective health may have been accomplished by the discussion on health related topics in the course. A study into the characteristics of the older people of Ridderkerk who were interested in participation in the course, showed a lower wellbeing among the interested people compared to the not interested (Kocken and Voorham, 1998). Both the experimental and control group were recruited from the older adults who showed interest. Apparently they subscribed to the course in order to work on their health. The need of members of the control group for information and to change their behaviour may explain the decline in perceived social support and subjective health, while they were on the waiting list.

The theoretical model presented in this article is hypothetical, although this study did shed some light on the mechanism of change for wellbeing through participation in a peer-led health education program. A closer study into the determinants of social participation has yet to be undertaken. This evaluation showed that the message of the peer educators to stay active had, after three months, strengthened the course participants in their opinion that society attaches importance to the elderly. The course was not powerful enough to change all determinants of social participation. The experimental group did not take up more activities, however the follow up period of three months may have been too short to show an effect. Other strategies that link up with the course objective of promotion of social participation have to be considered to enlarge effectiveness. For instance site visits to social activities may be added to the course program of "Successful Aging". The evidence from the literature on the beneficial effect of social participation on wellbeing could not be confirmed in this study, however a direct effect of the course on social support and subjective health of its members was present. They experienced increased social support and a better subjective health. 


\section{References}

Abler, R.M., Fretz, B.R. (1988) Self-efficacy and competence in independent living among oldest old persons. J. Gerontol. B Soc Sci: 43, S138-143.

Achenbaum, W.A., Bengtson, V.L. (1994). Re-engaging the disengagement theory of aging: on the history and assessment of theory development in gerontology. Gerontologist. 34. 756-763.

Adelmann, P.K. (1994). Multiple roles and psychological wellbeing in a national sample of older adults. J. Gerontol. Soc Sci: 49, S277-S285

Ajzen, I. The theory of planned behaviour. (1991). Organ Behav Hum Decis Process: $50,-179-211$.

Ajzen, I., Madden, Th. J. (1986). Prediction of goal-directed behaviour: attitudes, intentions, and perceived behavioral control. J. Exper. Soc Psychol, 22, 453-474.

Atchley, R. (1976). The sociology of retirement. New York. Halsted Press.

Bandura, A. (1986). Social foundations of thought and action; a social cognitive theory. Engelwood. Cliffs New Jersey. Prentice Hall.

Bosscher, R., Laurijssen, L., Boer, E. de. (1992). Competentie op later leeftijd; een exploratieve studie. [Competence in later life; an explorative study]. Bewegen \& Hulpverlening, 9, 255-265.

Campbell, R., Chenoweth, B. (1981). Health education as a basis for social support. Gerontologist, 21, 619-627.

Cumming, E., Henry, W. (1961). Growing old. The process of disengagement. New York: Basic Books.

Eijk, L. van. (1997). Activity and wellbeing in the elderly. Amsterdam. Thesis Publishers.

Fengler, A.P. (1984), Life satisfaction of subpopulations of elderly. The comparative effects of volunteerism, employment and meal site participation. Res Aging, 6,189-212.

Grembowski, D., Patrick, D., Diehr, P., Durham, M., Beresford, S., Kay, E., Hecht, J. (1993). Self-efficacy and health behaviour among older adults. J. Health. Soc Behav, 34, 89-104.

Hanson, B.S., Isacsson, S., Janzon, L., Lindell, S. (1989). Social network and social support influence mortality in elderly men. Am J. Epidemiol, 130, 100-111.

Havighurst, R., Neugarten, B., Tobin, S. (1968), Disengagement and patterns of aging. Neugarten, B, ed. Middle age and aging. Chicago. London. University of Chicago Press.

Kelly, J.R., Ross, J. (1988). Later-life leisure: beginning a new agenda. Leisure Sci, 11, 47-59.

Kempen, G.I.J.M. (1992). Het meten van de gezondheidstoestand van ouderen; een toepassing van een Nederlandse versie van de MOS-schaal. [Assessment of health status among 
the elderly; an application of a Dutch version of the MOS-survey]. Tijdschr Gerontol Geriatr, 23, 132-140.

Kempen, G.I.J.M. (1992). The MOS Short-form General Health Survey; single item versus multiple measures of health-related quality of life: some nuances. Pychol Rep, 70, -608-610.

Kocken, P.L., Voorham, A.J.J. (1998). Interest in participation in a peer-led senior health education program. Patient Education and Counselling: 34, 5-14.

Linschoten, C.P., Gerritsen, J.C., Romijn, C. (1993). De Schaal Subjectief Welzijn Ouderen nader onderzocht [A closer look at the Scale for Subjective Wellbeing of the Elderly].

Tijdschr Gerontol Geriatr, 24, 57-65.

Maibach, E., Murphy, D.A. (1995). Self-efficacy in health promotion research and practice: conceptualization and measurement. Health Educ Res, 10, 37-50.

Norusis, M.J. (1992). SPSS; SPSS/PC+ advanced statistics. Chicago.

Oxman, Th.E., Berkman, L.F., Kasl, S., Freeman, D.H., Barrett, J. (1992). Social support and depressive symptoms in the elderly. Am J. Epidemiol, 135, 356-368.

Pearson, R.E. (1990). Counselling and social support; perspectives and practice. Newbury Park. London. New Delhi. Sage.

Rodin, J., McAvay, G. (1992), Determinants of change in perceived health in a longitudinal study of older adults. J Gerontol Psychol Sci, 47, p373-384.

Rogers, E.M. (1983). Diffusion of innovations. 3d ed. New York. Free Press.

Sherer, M., Maddux, J.E., Mercandante, B., Prentice-Dunn, S., Jacobs, B., Rogers, R.W. (1982). The self-efficacy scale: construction and validation. Psychol Rep, 51, 663-671.

Sonderen, E. van. (1991). Het meten van sociale steun. [Measurement of social support]. Groningen Dissertation.

Stewart, A.L., Ware, J.E. eds. (1992). Measuring functioning and wellbeing. The Medical Outcomes Study approach. Durhmam/London. Duke University Press.

Thoits, P.A. (1995). Stress, coping, and social support processes: where are we? What next? $\checkmark$ Health Soc Behav, extra issue 53-79.

Vries, H. de, Backbier, E., Kok, G.J., Dijkstra, M. (1995). The impact of social influence in the context of attitude, self-efficacy, intention and previous behaviour as predictors of smoking onset. J. Appl Soc Psychol, 25, 237-257.

Vries, H., de, Dijkstra, M., Kuhlman, P. (1988). Self-efficacy: the third factor besides attitude and subjective norm as a predictor of behavioural intentions. Health Educ Res 3, 273-82.

Yasuda, N., Zimmerman, S.I.. Hawkes, W., Fredman, L., Hebel, J.R., Magaziner, J. (1997). Relation of social network characteristics to 5-year mortality among young-old versus old-old white women in an urban community. Am J Epidemiol, 145, 516-523. 



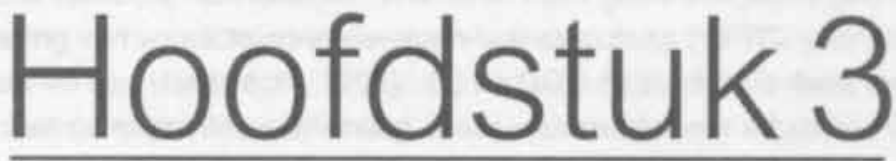

Kenmerken van de voorlichter bij het effect van seniorenvoorlichting, een kwantitatieve procesevaluatie 


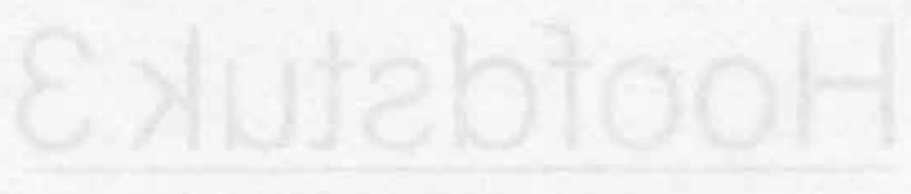

\section{Samenvatting}

In de gezondheidsvoorlichting is de voor-en-door methode (peer education) populair. Toch is er weinig bekend over de principes van de werkzaamheid van de methode. Deze analyse geeft een empirische onderbouwing voor de theoretische uitgangspunten van de voor-en-door voorlichting.

Bij seniorenvoorlichting volgens de voor-en-door methode is nagegaan of de rol van de voorlichter zoals gepercipieerd door de respondent én de seksegelijkheid (mannelijke voorlichter met mannelijke respondent en vrouwelijke voorlichter met vrouwelijke respondent) van invloed is op de effectiviteit van de voorlichting. In hoeverre is het subjectieve beeld van de peer-voorlichter en de objectieve seksegelijkheid van invloed op het effect van de voorlichting? Er zijn regressieanalyses uitgevoerd met deze procesvariabelen als onafhankelijke en de verschilscores van voor-en nameting van zes uitkomstvariabelen als afhankelijke variabelen. Geconcludeerd wordt dat vooral seksegelijkheid de effectiviteit van de voorlichting voorspelt, met name bij de lager opgeleiden en de ouderen. Een uitzondering op dit patroon vormt de invloed op het 'oordeel over de eigen gezondheid', waarbij een gunstig beeld van de voorlichter juist geen of een negatief effect voorspelt. Vermoedelijk speelt de vergelijking van de eigen gezondheid met die van de voorlichter daarbij een rol en de objectieve achteruitgang van de gezondheid in de periode tussen de voor-en de nameting. 


\section{Kenmerken van de voorlichter bij het effect van seniorenvoorlichting}

\subsection{Inleiding}

In de gezondheidsvoorlichting in Nederland wordt steeds vaker de zogenaamde vooren-door methode gebruikt. Bij deze 'peer education' worden vertegenwoordigers van de doelgroep getraind om aan hun 'peers' voorlichting te geven over gezondheid. In Nederland heeft die methode van voorlichten een grote stimulans gekregen door de ontwikkeling van voorlichting-in-de-eigen-taal-en-cultuur (VETC) voor migranten (Voorham en van Haastrecht, 1996). Bij de GGD Rotterdam is deze methode ook gestart met de migrantenvoorlichting. Maar intussen is peer education gebruikt bij de voorlichting over Aids voor homoseksuele mannen, en nu ook bij de voorlichting over gezondheid voor-en-door senioren. Uitgangspunt is dat door de (groepsgewijze) voorlichting door een vertegenwoordiger uit de doelgroep de totale effectiviteit van de voorlichting wordt vergroot. Eerder is aangetoond dat seniorenvoorlichting over 'succesvol ouder worden' effectief is op een aantal uitkomstvariabelen als er een vergelijking gemaakt wordt tussen een experimentele en een controlegroep (Kocken en Voorham, 1998). In die analyse blijkt de absolute vooruitgang in de experimentele groep relatief klein. Alleen in de vergelijking met de controlegroep kan er op een aantal uitkomstvariabelen een significant effect worden aangetoond. Het effect van de voorlichting is dus voor een deel het voorkomen van achteruitgang. In dit artikel zal voor de experimentele groep worden nagegaan of de kenmerken van de voorlichter samenhangen met de effectiviteit van de voorlichting. Mogelijk geeft dat ook meer inzicht in de relatief geringe vooruitgang bij de interventiegroep.

\subsection{Theoretische basis van de voor-en-door strategie}

Het denken over de bijdrage van de bron en het medium aan de effectiviteit van de voorlichting staat aan de basis van de voorlichtingskunde zelf. In zijn sociale leertheorie benadrukt Bandura (1986) het belang van de 'vicarious experience' ('seeing or visualising other similar people perform...') voor de ontwikkeling van persoonlijke effectiviteit. Rogers (1984) benadrukt in zijn theorie over de verspreiding van innovaties het principe van 'homophily'. Een individu wordt gemakkelijker beïnvloed door iemand met dezelfde achtergrond wat betreft waarden, geloof, opleiding of status. In het communicatie-onderzoek naar het effect van de massamedia werd een 'two-step-flow-of-communication' aangetoond, dat wil zeggen dat het meeste effect van massamedia uiteindelijk tot stand komt via persoonlijke communicatie van 'opinion leaders' in de gemeenschappen. Daarom lag het voor de hand om juist deze opinion leaders, als de 'primus inter pares' van de betrokken gemeenschap als voorlichtingsmedium te gaan zien, en hen op die manier ook in te schakelen. Vanuit de theorie zijn er voldoende aangrijpingspunten om peer education veelbelovend te vinden. Maar er zijn ook aanwijzingen dat vaak 
lichtvaardig gekozen wordt voor een strategie gebaseerd op peer-voorlichting.

Frankham (1998) laat zich zeer kritisch uit over de toepassing van peer education over aids en over roken in de schoolsituatie. In haar ogen is de methode gebaseerd op vooronderstellingen die niet kunnen worden hardgemaakt. Bij rookpreventie wijst zij erop dat jongeren niet alleen kunnen afzien van roken omdat hun vrienden het nalaten, maar juist ook vrienden maken omdat ze wel of niet roken. Dezelfde opvatting koestert Miburn (1995) die specifiek naar projecten rond seksuele gezondheid keek.

Bijvoorbeeld de vooronderstelling dat jongeren onderling gemakkelijker over seks praten geldt maar voor een zeer beperkte groep. Zij stelt dat ideologische overwegingen belangrijk zijn geweest bij de ontwikkeling van deze 'peer education'. Hierdoor wordt deze strategie kritiekloos overgenomen, met het gevaar dat voorlichtingskundig belangrijke aspecten te gemakkelijk worden veronachtzaamd zoals de specifieke kenmerken van de doelgroep. Ook bij de seniorenvoorlichting hebben ongetwijfeld ideologische motieven een rol gespeeld bij de keuze voor de voor-en-door-methode. In het kader van het Gezonde Stad beleid was 'de betrokkenheid van de doelgroep' een zeer belangrijke randvoorwaarde voor de acceptatie en financiering van een project (Hofman en de Haes, 1994).

Er zijn evenwel empirische aanwijzingen voor effectiviteit. Watkins e.a. (1994) laten zien dat 'lay health advisors' (LHA's) effectief kunnen worden ingeschakeld voor opvoedingsvoorlichting aan gemigreerde landarbeiders. Earp e.a. (1997) tonen aan dat het inschakelen van LHA's werkt bij de voorlichting over borstkanker. Rijke en De Vries (1995) vergelijken 17 studies waarbij jongeren worden ingeschakeld bij gezondheidsvoorlichting. In meer dan de helft van de gevallen blijken ze effectiever dan leraren of andere volwassenen. Maar onder welke voorwaarden dat het geval is wordt niet geheel duidelijk. Zeer recent constateren Turner en Shepherd (1999) in een review dat er veel claims voor de effectiviteit van peer-education bestaan maar dat er weinig referenties naar de theorie en empirisch bewijs bestaan. Het is opvallend dat ook zij vrijwel alleen maar projecten voor jongeren beschrijven. Zij beschrijven tien vaak gebruikte rechtvaardigingen voor peer education en gaan op zoek naar de theorieën die de claim kunnen ondersteunen. Hun conclusie is dat er veel claims gerechtvaardigd lijken, maar dat er meer empirisch bewijs nodig is. Met name vragen ze zich af hoe belangrijk het rolmodel van de peer is vanuit de sociale leertheorie, en hoe belangrijk de kenmerken zijn van de opinieleider in het kader van de innovatietheorie.

\subsection{Probleemstelling}

Om keuzes te maken voor effectieve vormen van voorlichten heeft McGuire (1985) een 'communication persuation matrix' gemaakt. Het biedt een theoretisch kader waarbinnen een voorlichtingsmethodiek kan worden getoetst en kan dus een leidraad zijn om te bepalen hoe een voorlichtingsmethode kan worden geëvalueerd. Waarom werkt de interventie (beter)? McGuire onderscheidt variabelen met betrekking tot de ontvanger, het kanaal, het medium, de boodschap en de bron. In deze analyse staan de bronvariabelen centraal: welke kenmerken heeft de bron (de seniorenvoorlichter) die de 
voorlichting effectiever maken? De Vries (1992) stelt dat voor de overtuigingskracht van de bron onder andere van belang zijn: de geloofwaardigheid en de attractiviteit van de bron. De attractiviteit van de bron wordt bepaald door meerdere aspecten zoals fysieke aantrekkelijkheid, non-verbaal gedrag en similariteit (gelijkheid). En de gelijkheid kan slaan op herkomst, leeftijd, geslacht, ideologie, etc. Bij de seniorenvoorlichting wordt nadrukkelijk de gelijkheid met betrekking tot leeftijd als een effectieve strategie toegepast. Ouderen geven voorlichting aan ouderen. Zij zijn "één met de doelgroep" of bondgenoot. De seniorvoorlichters zijn een rolmodel voor de ouderen in de groep. In de rol van de seniorvoorlichter wordt de positieve houding ten opzichte van het ouder worden als het ware belichaamd. Op dezelfde manier is ook een 'gelijkwaardige' manier van voorlichten door de participanten om meningen te vragen en discussie te stimuleren, een uiting van similariteit. De gelijkheid met betrekking tot sekse wordt op dit moment niet als strategie gebruikt, en in deze analyse wordt nagegaan of seksegelijkheid invloed heeft. Een bron is geloofwaardig als ze competent en betrouwbaar wordt gevonden.

Samenvattend bevat seniorenvoorlichting de volgende elementen die de effectiviteit beogen te verhogen, en die we in dit procesonderzoek kunnen onderzoeken:

- De mate waarin de voorlichter volgens de respondent kenmerken heeft van similariteit (gelijkheid) en geloofwaardigheid. Dit subjectieve concept noemen we kortweg de 'voorlichtersrol'.

- De objectieve vaststelling of er al dan niet sprake was van gelijkheid in sekse (een vrouw geeft voorlichting aan een vrouw of een man geeft voorlichting aan een man. is gelijkheid in sekse:'seksegelijkheid').

Aldus luidt de vraagstelling in dit procesonderzoek: In hoeverre kan uit een score op de procesvariabelen seksegelijkheid en voorlichtersrol de mate van effectiviteit van de voorlichting worden voorspeld?

\subsection{Opzet van het onderzoek: De cursus 'Succesvol ouder worden'.}

De cursus 'Succesvol ouder worden' bestond uit vier bijeenkomsten. De eerste was een inleiding over de schijf van 'succesvol ouder worden', waarbij de voorlichter de determinanten van het succesvol ouder worden, zoals sociale steun, gezonde leefwijzen, voldoende inkomen en voldoende zelfvertrouwen in het eigen kunnen, behandelde (Voorham e.a., 1995). Op basis van deze inleiding koos de groep de onderwerpen van de volgende drie bijeenkomsten. In elke bijeenkomst werd één onderwerp behandeld en een bijeenkomst duurde ongeveer twee uur. De cursus in het kader van het evaluatieonderzoek werd uitgevoerd in Ridderkerk. In de zes series van vier bijeenkomsten die in het onderzoek zijn geëvalueerd werden de volgende onderwerpen behandeld: slaapproblemen, geheugenproblemen, medicijngebruik, woonvoorzieningen voor ouderen, osteoporosis, lichaamsbeweging voor ouderen, en ouder worden in verschillende culturen. Alle zelfstandig wonende ouderen in Ridderkerk tussen 55 en 79 jaar werden schriftelijk uitgenodigd aan de cursus mee te doen. Bij elkaar hadden 320 ouderen 
gereageerd op de schriftelijke oproep. Bij de experimentele groep werden 138 mensen ingedeeld, en de rest werd ingedeeld bij de controlegroep. Zij kregen de cursus na het onderzoek aangeboden. Omdat alleen de ouderen in de experimentele groep voorlichting kregen, en alleen zij een oordeel over de voorlichter hebben kunnen geven, kan dit procesonderzoek slechts gebruik maken van de gegevens van de experimentele groep. De respons in de experimentele groep op alle drie meetmomenten was $51 \%$. Het geslacht, de leeftijd en de burgerlijke staat van de responsgroep verschilde niet van de oorspronkelijk geselecteerde experimentele groep. Ook verschilde de experimentele en controlegroep niet van elkaar, noch waren er verschillen te zien op de uitkomstvariabelen in de voormeting.

\subsection{Variabelen}

De uitkomstvariabelen houding ten opzichte van ouder worden, de sociale invloed, de eigen effectiviteit, sociale steun, subjectief welbevinden en het oordeel over de eigen gezondheid werden als volgt geoperationaliseerd. De houding ten opzichte van ouder worden werd gemeten met vijf items die een schaal vormen met negatieve en positieve meningen over het ouder worden, zoals bijvoorbeeld: 'Als je oud bent lijken alle dagen op elkaar' $(\alpha=0,64)$. De perceptie van de mening van de omgeving over de positie van ouderen werd vastgesteld met één item: 'Ouderen hebben te weinig zeggenschap'. Persoonlijke effectiviteit werd gemeten met de gevalideerde schaal voor algemene persoonlijke effectiviteit, die de verwachtingen meet met betrekking tot persoonlijke effectiviteit over een groot scala van activiteiten. De schaal bestaat uit 16 items, zoals bijvoorbeeld: 'Wanneer ik besloten heb om iets te doen, dan doe ik het ook' $(\alpha=0,8-3)$ (Sherer e.a., 1982; Bosscher e.a., 1992). Sociale steun werd gemeten met de gevalideerde schaal voor gepercipieerde alledaagse steun, bestaand uit items zoals: 'Heeft $u$ het gevoel dat men aandacht voor $u$ heeft?' $(\alpha=0,88)$ (van Sonderen, 1991). Welzijn werd gemeten met de korte versie van de gevalideerde schaal voor subjectief welzijn (SSWO, 8 items) (Linschoten en van den Heuvel, 1989). De schaal meet positieve en negatieve gevoelens en ervaringen van de respondent, bijvoorbeeld: 'Over het geheel genomen ben ik tevreden over mezelf' $(\alpha=0,81)$. Oordeel over de eigen gezondheid werd gemeten met een vraag waarbij de respondent zijn of haar gezondheid een rapportcijfer kon geven van 1 (heel slecht) tot 10 (heel goed). Daarnaast werd in de vragenlijst gevraagd naar de volgende achtergrondkenmerken: geslacht, leeftijd, burgerlijke staat en opleiding.

Voor de ontwikkeling van een schaal van de rol van de voorlichter zijn bij de start van het project een 60-tal items aan een grote groep ouderen voorgelegd. Op basis van die antwoorden zijn 15 items overgebleven die goed onderscheiden. De voorlichter moet geloofwaardig overkomen, maar hij mag niet te schools zijn. Hij moet weten waar hij het over heeft, niet te veel aarzelen, maar moet ook discussie stimuleren. Hij moet een voorbeeld zijn, een vriend van wie je kan leren (zie tabel 1 voor de 15 items). Voor de analyse zijn de items zodanig gescoord dat hoe hoger de score, hoe meer de respondent positieve gewenste eigenschappen aan de voorlichter toeschrijft (range 15-45, 
$\alpha=0,76$ ). De missende waarden (maximaal 2 ) zijn vervangen door het gemiddelde van de scores op de andere items.

\subsection{Analyse}

In deze procesanalyse hebben we de verschilscores gebruikt van de voormeting en de eerste nameting. Uitgegaan is van een multiple regressiemodel met de verschilscore van de uitkomstvariabele als afhankelijke en de beide procesvariabelen voorlichtersrol en seksegelijkheid als determinanten, met leeftijd, geslacht, burgerlijk staat en opleiding als covariaten. Daar waar sprake was van interactie is de analyse per stratum uitgesplitst.

\subsection{Resultaten}

In Tabel 1 staan de frequenties van de antwoorden op de items van de rol-schaal, waarbij opvalt dat de mening over de voorlichter over het algemeen positief is. Er is geen enkel item waarbij het grootste deel van de groep een negatief oordeel heeft. Er zijn duidelijk ook items waarover de groep verdeeld is, zoals over de voorlichter als voorbeeld, het strakke programma, de zakelijke voorlichter, en de voorkeur voor een huisarts.

Nagegaan is ook of de scores op de rol van de voorlichter verschilt voor respondenten met de achtergrondkenmerken sekse, opleiding, leeftijd, burgerlijke staat en de seksegelijkheid in de voorlichting. Bij geen van deze variabelen is er een verschil in de score op de voorlichtersrol vast te stellen. Er is dus ook geen verschil in score op de rolschaal voor de groep die een voorlichter van de eigen sekse had en de groep die dat niet had. Dit geldt ook op itemniveau, bijvoorbeeld voor het item 'De voorlichter was een voorbeeld voor mij' is er geen significant verschil voor seksegelijkheid. Blijkbaar kan in de context van deze voorlichting een man als oudere een voorbeeld zijn voor een vrouw als oudere, en andersom.

In Tabel 2 staan de gemiddelde scores en de verschilscores van de uitkomstvariabelen sociale invloed van ouderen, attitude ten opzichte van het ouder worden, het subjectief welbevinden, het oordeel over de eigen gezondheid en de eigen effectiviteit voor $\mathrm{t} 1$-to vermeld. 


\begin{tabular}{|c|c|c|c|c|}
\hline & $\begin{array}{r}\text { mee eens } \\
\mathrm{n}(\%)\end{array}$ & $\begin{array}{r}\text { niet eens, } \\
\text { niet oneens } \\
n(\%)\end{array}$ & $\begin{array}{r}\text { oneens } \\
n(\%)\end{array}$ & $\begin{array}{l}\text { niet in- } \\
\text { gevuld } \\
n(\%)\end{array}$ \\
\hline De voorlichter wist op alle vragen antwoord & $53(62)$ & $23(27)$ & $6(7)$ & $3(4)$ \\
\hline De voorlichter aarzelde bil antwoorden & $9(11)$ & $12(14)$ & $59(69)$ & $5(6)$ \\
\hline $\begin{array}{l}\text { De voorlichter was onzeker } \\
\text { Ik had het gevoel dat een goede vriend me } \\
\text { informatie gaf }\end{array}$ & $4(5)$ & $9(11)$ & $67(79)$ & $5(6)$ \\
\hline $\begin{array}{l}\text { De voorlichter liet duidelifk merken dat hij het } \\
\text { beter wist }\end{array}$ & $45(53)$ & $21(25)$ & $15(18)$ & $4(5)$ \\
\hline $\begin{array}{l}\text { Je kunt toch beter een huisarts als voorlichter } \\
\text { hebben }\end{array}$ & $5(0)$ & & $62(73)$ & $4(5)$ \\
\hline De voorlichter vroeg de groep vaak om een. & $10(12)$ & $30(35)$ & $38(45)$ & $7(8)$ \\
\hline mening & $64(75)$ & $8(9)$ & $9(11)$ & $4(5)$ \\
\hline De voorlichter was zakelijk & $29(34)$ & $31(37)$ & $23(27)$ & $2(2)$ \\
\hline $\begin{array}{l}\text { De voorlichter liet bijna geen discussie ontstaan } \\
\text { in de groep. }\end{array}$ & $4(5)$ & $12(14)$ & $63(74)$ & $6(7)$ \\
\hline In de voorlichter herkende ik mijzelf & $19(22)$ & $32(38)$ & $30(35)$ & $4(5)$ \\
\hline Ik had het gevoel in de klas te zitten & $10(12)$ & $16(19)$ & $55(65)$ & $4(5)$ \\
\hline De voorlichter hield zich strak aan zijn programma & $24(28)$ & $34(40)$ & $23(27)$ & $4(5)$ \\
\hline Ik heb veel van de voorlichter geleerd & $36(42)$ & $32(38)$ & $14(17)$ & $3(40$ \\
\hline De voorlichter is een voorbeeld voor mij & $27(32)$ & $30(35)$ & $24(28)$ & $4(5)$ \\
\hline De voorlichter heeft mijn mening veranderd & $9(11)$ & $32(38)$ & $40(47)$ & $4(5)$ \\
\hline
\end{tabular}

- De gewenste antwoorden zijn vet afgedrukt.

Cronbach's Alpha ( 15 items, $n=85$ ) $=0,76$

\begin{tabular}{|c|c|c|c|c|}
\hline Afhankelijke variabelen & N & to & t1 & t1-to \\
\hline Sociale invloed (1-5) & 79 & 2,33 & 2,47 & 0.14 \\
\hline Attitude L.a.k ouder worden (5-25) & 82 & 17.76 & 17,67 & $-0,08$ \\
\hline Sociale steun (14-40) & 75 & 31.45 & 32,00 & 0,55 \\
\hline Subjectief welbevinden $(0-20)$ & 77 & 14,66 & 14,51 & $-0,14$ \\
\hline Eigen effectiviteit (36-80) & 75 & 59,81 & 61,35 & 1,53 \\
\hline Dordeel over eigen gezondheid (1-10) & 72 & 7,16 & 7,34 & 0,17 \\
\hline
\end{tabular}




\begin{tabular}{|c|c|c|}
\hline Afhankelijke variabelen & $\begin{array}{r}\text { Voorlichtersrol } \\
\beta\end{array}$ & $\begin{array}{r}\text { Seksegelijkheid } \\
\beta\end{array}$ \\
\hline Sociale invioed (1-5) & $-0,11$ & 0,001 \\
\hline Attitude t.a.k ouder worden (5-25) & 0,002 & 0,125 \\
\hline $\begin{array}{c}\text { Sociale steun }(14-40) \\
\text { Opleiding laag } † \\
\text { Opleiding hoog } \\
\text { Geslacht vrouw } \\
\text { Geslacht man }\end{array}$ & $\begin{array}{l}-0,09 \\
-0,05 \\
-0,25 \\
-0,06 \\
-0,25\end{array}$ & $\begin{array}{r}0,21 \\
* 0,56 \\
-0,16 \\
0,26 \\
0,04\end{array}$ \\
\hline $\begin{array}{c}\text { Subjectief welbevinden }(0-20) \\
\text { Opleiding laag } \\
\text { Opleiding hoog } \\
\text { Jonger dan } 65 \text { jaar } \\
\text { Ouder van } 65 \text { jaar }\end{array}$ & $\begin{array}{r}r 0,17 \\
-0,05 \\
*-0,39 \\
\cdot-0,44 \\
0,09\end{array}$ & $\begin{array}{r}\cdot 0,21 \\
\cdot 0,31 \\
0,14 \\
0,09 \\
\cdot 0,28\end{array}$ \\
\hline $\begin{array}{l}\text { Eigen effectiviteit }(36-80) \\
\text { Jonger dan } 65 \text { jaar } \\
\text { Ouder van } 65 \text { jaar }\end{array}$ & $\begin{array}{l}0,19 \\
0,22 \\
0,19\end{array}$ & $\begin{array}{r}0,22 \\
0,08 \\
* 0,36\end{array}$ \\
\hline $\begin{array}{c}\text { Oordeel over eigen gezondheid }(1-10) \\
\text { Jonger dan } 65 \text { jaar } \\
\text { Ouder dan } 65\end{array}$ & $\begin{array}{r}0,03 \\
-0,33 \\
0,19\end{array}$ & $\begin{array}{l}0,19 \\
0,07 \\
0,28\end{array}$ \\
\hline
\end{tabular}

-ps 0,$10 ; \cdots p \leq 0,05 ; \cdots p \leq 0,001$

t $\mathrm{De} \beta$ binnen de strata van de variabelen met interactie met de procesvariabelen.

Bij geen enkele uitkomstvariabele is er een significant verschil tussen de voor - en de nameting. Bij de attitude ten opzichte van ouder worden en het subjectief welbevinden is er zelfs een niet significante lichte achteruitgang. In de Tabel 3 staan de gestandaardiseerde regressiecoëfficiënten van de procesvariabelen 'voorlichtingsrol' en 'seksegelijkheid' in de multiple regressiemodellen met de verschilscores als de afhankelijke variabelen. Er blijkt geen significante bijdrage te zijn van de procesvariabelen op de toe- of afname bij de gepercipieerde sociale invloed en de attitude ten opzichte van het ouder worden. Bij sociale steun laat de verschilscore een lichte vooruitgang zien (Tabel 2), en blijkt dat seksegelijkheid van invloed is (Tabel 3). En daarbij is ook een interactieeffect te zien: de vooruitgang in sociale steun is in de groep laag opgeleiden en bij de vrouwen groter indien de voorlichter en deelnemer van gelijke sekse zijn. Het subjectief welbevinden gaat er bij de onderzoeksgroep heel licht op achteruit. Ook hier is er een gunstiger effect, met interactie met leeftijd, wanneer sprake is van seksegelijkheid. De ouderen en de lager opgeleiden die een voorlichter van hetzelfde geslacht hadden gaan er op vooruit. Er is evenwel een negatieve samenhang met de voorlichtersrol, vooral bij de hoger opgeleiden en de jongeren van de doelgroep. Bij de eigen effectiviteit is er vooruitgang tussen to en $\mathrm{t1}$ (Tabel 2). Als de voorlichter van hetzelfde geslacht is dan is er een groter verschil tussen de voor en de nameting bij de variabele eigen effectiviteit. Voor de oudere ouderen is het effect van seksegelijkheid sterker dan voor de jongeren onder de ouderen. Bij het oordeel over de eigen gezondheid is tussen 
to en 11 gemiddeld een lichte vooruitgang te zien (Tabel 2). Hier is een negatieve samenhang zichtbaar voor de jongeren. Hoe gunstiger het beeld van de voorlichter, hoe ongunstiger het effect op het oordeel over de eigen gezondheid. Het meest opvallende van Tabel 3 is dat seksegelijkheid een belangrijker factor blijkt te zijn als voorspeller van het effect dan de score op de voorlichtersrol. De score op de voorlichtersrol hangt zelis meestal negatief samen met een verschilscore, dat wil zeggen hoe gunstiger het beeld van de voorlichter, hoe kleiner het effect van de voorlichting.

\subsection{Conclusie}

Bij seniorenvoorlichting volgens de voor-en-door methode is nagegaan of de rol van de voorlichter én de seksegelijkheid als procesvariabelen van invloed zijn op de veranderingen in de effectmaten van de voorlichting. Voor de meeste uitkomstvariabelen wordt aangetoond dat vooral de seksegelijkheid samenhangt met de effectiviteit van de voorlichting. Bij gelijke sekse van voorlichter en voorgelichte is er een sterker effect. De subjectieve mening over de rol van de voorlichter speelt als voorspeller van effect een minder grote rol en heeft ook een onverwachte richting. Mogelijk speelt hier de objectieve achteruitgang van de gezondheid een rol, en de vergelijking die de deelnemers van de voorlichting geneigd zijn te maken met de opvattingen en het welbevinden van de voorlichter. Voor een deel zijn deze resultaten een empirische onderbouwing voor de uitgangspunten van de voor-en-door methode. Bij een aantal uitkomstvariabelen is er interactie met leeftijd, met opleiding en met geslacht. Vooral de lager opgeleiden, de ouderen en de vrouwen blijken gevoelig voor de seksegelijkheid van de voorlichter. Deze resultaten laten zien dat seksegelijkheid van invloed is op de effectiviteit van de voorlichting. Het is gunstiger om de mannen door de mannen en de vrouwen door de vrouwen te laten voorlichten. Overigens creëren we daarmee een nieuwe situatie van seksehomogene groepen, die op zichzelf positieve of negatieve effecten kan hebben, bijvoorbeeld omdat het groepsproces anders is.

Dit onderzoek betreft seniorenvoorlichting volgens de voor-en-door methode. In dit geval wordt het gelijkheidsprincipe toegepast op de leeftijd, en nagegaan is of de gepercipieerde rol van de voorlichter en de seksegelijkheid in de voorlichting van invloed is. De voorlichters in dit project behoorden allen tot de 'jongere' groep onder de ouderen, en ze waren relatief hoger opgeleid. In dit geval laten de ouderen zich dus wel aanspreken door personen van iets jongere leeftijd. En juist bij de lager opgeleiden zagen een groter effect van de voorlichting. De grenzen van gelijkheid zijn niet vastomlijnd. Similariteit is niet hetzelfde als volledige gelijkheid. Onder de randvoorwaarden van gelijkheid spelen ook aspecten als attractiviteit en begerenswaardigheid mee (de homoseksuele man die op de 'baan' voorlichting geeft over veilig vrijen is bij voorkeur een aantrekkelijke man; de Turkse Aidsvoorlichter laat met zijn voorlichting zien dat hij meer geïntegreerd is in de Nederlandse samenleving dan de meeste toehoorders). De seniorenvoorlichter mag relatief jonger en hoger opgeleid zijn maar dient bij voorkeur wel van hetzelfde geslacht te zijn. De peer voorlichter is een 'primus inter pares'. In het ideale geval is het iemand waarmee je je in opwaartse zijn kunt vergelijken. In de opzet 
van de seniorenvoorlichting in Ridderkerk is geen rekening gehouden met seksegelijkheid in de voorlichting. In deze analyse blijkt seksegelijkheid een effectmodificator van de voorlichting. De praktijk van de gezondheidsvoorlichting voor-en-door senioren kan rekening houden met deze resultaten van dit onderzoek door systematischer te letten op de samenstelling van de groepen, en dan bewuster te kiezen voor een mannelijke of een vrouwelijk voorlichter. 


\section{Literatuur}

Bandura, A. (1986). Social foundations of thought and action; a social cognitive theory. Engle-wood Cliffs New Jersey: Prentice Hall.

Bosscher, R., Laurijssen, L., Boer, E. de (1992). Competentie op later leeftijd: een exploratieve studie. Bewegen \& Hulpverlening. 9, 255-265.

Earp, J.A.L., Viadro, C.I., Vincus, A.A., Altpeter, M., Flax, V., Mayne, L., Eng, E. (1997). Lay health advisors: A strategy for getting the word out about breast cancer. Health Education \& Behavior. 24, 432-451

Frankham, F. (1998). Peer Education: the unauthorised version. British Educational Research Journal, vol. 24, no 2. 179-191.

Hofman, H.A.L., Haes, W.F.M. de (1994). Over preventie en ouderen: een theoretische benadering. Handboek Thuiszorg. VUGA.

Kocken, P.L., Voorham, A.J.J. (1998). Effects of a peer-led senior health education program. Patient Education and Counselling 34, 15-23.

Linschoten, C.P. Heuvel, W.J.A. van de (1989). GVO/preventie voor ouderen, aanknopingspunten voor beleid. Tijdschrift Gezondheidsbevordering. 10. 53-62.

McGuire, W.J. (1985). Attitudes and attitude change. In: Lindsay G, Aronson E (Eds). The handbook of Social Psychology. Volume 2. New York. Random House. 233-346.

Milburn, K. (1995). A critical review of peer education with young people with special reference to sexual health. Health education Research. vol 10. no 4. pp 407-420.

Rijke, B., Vries, N. de. (1995). 'Peers doen het beter...I Peer-voorlichting bij jongeren', Tijdschrift Gezondheidsbevordering. jrg. 16. no 3-4. pp 103-116.

Rogers, E.M. (1984). Diffusions of Innovations. Free Press. New York.

Sonderen, F.L.P. van (1991). Het meten van sociale steun. Proefschrift Rijksuniversiteit Groningen.

Sherer, M., Maddux, J.E., Mercandante, B., Prentice-Dunn, S., Jacobs, B., Rogers, R.W. (1982). The self-efficacy scale: construction and validation. Psychol Rep. 51, 663-671.

Turner, G., Shepherd, J. (1999). A method in search of a theory: peer education and health promotion, Health Education Research. (14)2.

Voorham, A.J.J., Haastrecht, P.M. van (1996). Gezondheidsbevordering: gekleurde samenleving, motor voor verandering. In: Haveman, H.B. en P. Uniken Venema (red.) Migranten en gezondheidszorg. Bohn Stafleu Vanloghum, Houten/Diegem.

Voorham, A.J.J., Kocken, P.L., Hofman, H.A.L., Kemme, G.H. (1995). Seniorenvoorlichting in Rotterdam. Uitgangspunten, onderzoek en praktijk. In: R. Sanderman e.a. (red.) Interveniëren in de determinanten van gezondheid. Van Gorcum. Assen. 
Vries, H. de (1992). Theorieën over voorlichting en gedragsverandering. In: Meertens, R.W. \& Grumbkow, J. von (red.) Sociale Psychologie. Wolters-Noordhoff Groningen. 2e herziene druk.

Watkins, E., Harlan, C., Eng, E. et al (1994). Assessing the effectiveness of Lay Health Advisors with Migrant Farmerworkers. Family and Community health. 16 (4). 



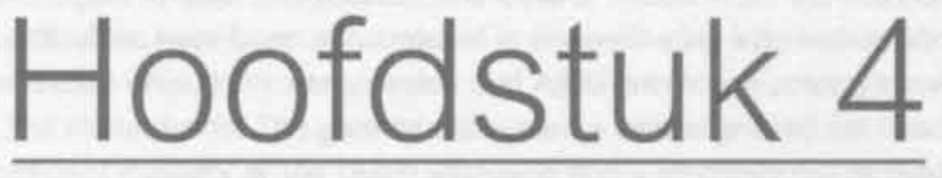

Effects of peer-led AIDS education aimed at Turkish and Moroccan male immigrants in the Netherlands 


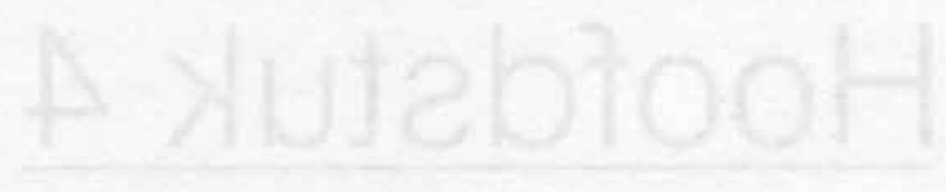

\section{.}

\section{Summary}

An evaluation study was conducted in The Netherlands into acquired immune deficiency syndrome (AIDS) education for immigrants given in their native language by peers. Turkish and Moroccan men were trained to educate people from their own ethnic group. The effect of peer education on the perceived threat of AIDS and beliefs about condom use were studied. Methods: Places where male immigrants met, i.e. coffee houses, mosques and bars, were matched and randomly assigned to experimental and control groups. The experimental group filled out a short questionnaire at the end of the education session (post-test), whereas the control group was pre-tested and had the opportunity of following the AIDS education after participation in the questionnaire. Results: Using multilevel logistic regression analysis, an effect could be established on misunderstandings regarding human immunodeficiency virus (HIV) transmission (OR=5.9 and $95 \% \mathrm{Cl}: 2.3-15.3$ ) and risk appraisal for HIV infection (OR=2.9 and $95 \% \mathrm{Cl}: 1.3-6.3$ ).

The perceived benefits of the protective effect of condom use were affected in men 30 years and older, the perceived barrier of diminished satisfaction if using condoms was changed among unmarried men, condom self-efficacy was affected in men who valued peer education as important and an effect on intention to use condoms was found among Moroccans. Conclusion: Continuation of peer-led AIDS education for immigrants and adaptation of the message to the needs of specific target groups is recommended. 


\section{Effects of peer-led AIDS education aimed at Turkish and Moroccan male immigrants in the Netherlands}

\subsection{Introduction}

In spite of the progress made in medical surveillance of acquired immune deficiency syndrome (AIDS), considerable effort still has to be paid to education and behavioural change with regard to safer sex (Coates and Collins, 1998). From the start of the AIDS epidemic, difficulties have been encountered in disseminating information about human immunodeficiency virus (HIV) transmission and AIDS prevention among immigrant groups in The Netherlands. The general mass media campaigns did not reach them due to insufficient mastery of the Dutch language and a tendency not to read the available literature about AIDS. In the late 1980s and the beginning of the 1990 s, with an ongoing AIDS prevention campaign in The Netherlands, the prevalence of sexually transmitted diseases (STDs) was higher among Turkish and Moroccan men compared to Dutch men and attendance at STD clinics among Turkish men was higher (Hooykaas et al., 1991; van de Laar et al, 1991; van der Hoek \& Coutinho, 1994). Among Turks and Moroccans some persistent misunderstandings existed about the transmission of HIV through saliva, mosquito bites and toilet use. Condom use was not common or inconsistent. Qualitative research among Turkish and Moroccan men showed that unsafe sex occurred among sexually active men. Condom use was viewed as unpleasant and there was resistance to its use because of a negative association with extramarital sex (Everaert \& Lamur, 1993; Gelder \& Lamur, 1993). A change could be observed among young Turkish and Moroccan male students of 11-18 years of age. Reported condom use increased from 1990 to 1995 to the Dutch adolescents' level (Brugman et al.,1997).

Lack of knowledge and presumed risk behaviour were the reasons for starting a peer education programme in 1989 in order to prevent AIDS among immigrants in The Netherlands. Immigrants from different ethnic origins, among others Turks, Moroccans, Surinamese, Netherlands Antilleans and Cape Verdeans, were trained as peer educators. They were recruited from volunteer ethnic minority organisations. The education of Turks and Moroccans is central in this article. AIDS education in their native language, allowing for cultural habits, was expected to be advantageous when considering the delicate nature of the field dealing with HIV transmission and sexual habits. Use of peer educators is recommended when access to hard-to-reach populations is pursued (Purley et al.,1996; Eng et al.,1997). Peer educators (sometimes also called paraprofessionals, community health advisors or lay health advisors) act as the link between the public health professional and the target group. The peer educator knows the places where the hard-to-reach gather, what health change message is acceptable and how the message can be best transferred. AIDS education by peers is thought to be 
effective because of the perceived trustworthiness of the information source and role modelling (Rogers, 1983; Bandura, 1986). The peer educators act as an example for their fellow citizens. The programme was an outreach programme and peer educators visited cafés, coffee-houses and mosques where the target group members met. The aims of the programme were to increase knowledge about AIDS, reduce unnecessary fears and misunderstanding and change the determinants of condoms use. The programme of AIDS education in the subjects' native language is evaluated in this article. Studies on the effectiveness of AIDS education aimed at immigrants in Europe are lacking. Information on beliefs about condom use among non-adolescent European migrant groups is scarce. The following research question is addressed in this article. What is the effect of peer-led AIDS education aimed at male Turkish and Moroccan immigrants on the perceived threat of AIDS and beliefs about condom use?

\subsection{The aids education session}

The AIDS education session took approximately 75 minutes including 30 minutes discussion. The peer educator gave an introduction using slides or posters. He gave information about the incidence of AIDS, spread over the world, viral infection, transmission routes including intravenous drug use and blood transfusion, heterosexual and homosexual contact, pregnancy and misunderstandings concerning transmission. With respect to prevention strategies use of condoms was emphasised. Several types of condoms were shown, the availability of condoms was mentioned and use of condoms was demonstrated. The peer educator did not address the sexual habits of the immigrants in an explicit way. Condom use in sexual contacts outside marriage was promoted without suggesting that the audience was having extramarital relationships. During the talk and at the end, the audience had the opportunity of asking questions and discussing themes such as how the virus works and symptoms of AIDS. An average of 23 men attended the sessions. The AIDS education in coffee houses, cafés and mosques was rather unstructured. People who happened to be present were invited to attend the session and were not always prepared for the AIDS education. In practice people walked in and out and part of the audience attended the entire session. The targets of the peer AIDS education programme were discussed with programme coordinators and peer educators in a qualitative procedure using the nominal group technique (Van de Ven \& Delbecq. 1972; Green \& Kreuter, 1991). The following targets were determined:

I) increased knowledge of AIDS,

II) clearance of misunderstandings and unnecessary fears of HIV transmission,

III) a realistic appraisal of the risk of attracting AIDS including erasing the prejudice

regarding AIDS being a disease of homosexuals and a disease related to nationality or culture and

IV) positive beliefs, self-efficacy and intentions regarding condom use.

These targets are equal to the determinants of behaviour in the Health Belief Model (Rosenstock et al.,1994; Janz \& Becker, 1984). The Health Belief Model is suitable 
when the behaviour change pursued is not too complex such as drawing people's attention to the danger of AIDS and the necessity of prevention (Nutbeam \& Harris, 1998). Two groups of factors in this model determine people's behaviour, i.e. the perceived threat of the illness under consideration and expectations with regard to the barriers and benefits when performing actions, which prevent or relieve the illness. The perceived threat of AIDS was distinguished in this study into risk appraisal for AIDS infection and beliefs and misunderstandings about HIV transmission. Moreover, effects on the following expectancies with regard to condom use were studied:

I) the barrier of diminished satisfaction with sex using condoms,

II) the barrier of buying condoms,

III) the benefit of the protective effect of condoms and

IV) perceived self-efficacy of using condoms.

Perceived self-efficacy of performing the behaviour has been added to the Health Belief Model in order to increase its explanatory power (Rosenstock et al., 1994). A person's self-efficacy or belief that he can successfully execute the behaviour is a strong predictor for performing the desired behaviour (Diclimente \& Peterson, 1994). The information transfer about AIDS by the peer educator will have an impact on the individual's appraisal of the risk of AIDS. Viewing others in the process of adopting new behaviours such as talking about condoms may influence the audience's expectations towards that behaviour. The peer educator as a role model demonstrating condoms may affect a person's confidence to perform the desired behaviour (Bandura, 1994).

\subsection{Method}

The setting of cafés and mosques raised some limitations to the design of the evaluation study. Randomisation of visitors was not possible. Instead, the localities in which the AIDS education took place were randomly assigned to the experimental and control groups. A stratified matching procedure was used, taking into account the following characteristics of the audience: nationality, type of locality, i.e. coffee house, mosque or other locality, estimated mean age and degree of conservatism. These characteristics were assessed beforehand by the peer educators. A pre-and post-test in a place where people walk in and out during the short time limit of one hour was not possible. The measurement was therefore confined to one pre- or post-test. The visitors to the localities that were assigned randomly to the experimental group received the post-test and the visitors of localities in the control group received the pre-test. The control group was given the opportunity of being educated after participation in the questionnaire. An additional difficulty was that many visitors were not used to filling out forms; in particular, some among the Moroccans were illiterate. The audience was asked to complete a short questionnaire. The questionnaire was called a 'quiz' in order to lower the threshold of participation in the study. In order to meet the expected reading problems, the peer educators went to the localities in pairs. One educator was responsible for the educational part. The other assisted people technically in completing the short questionnaire. Questions were read out loud and the positions of answer categories in the 
form were pinpointed when necessary. Sometimes the assistant educators helped individuals on request. The evaluation study took place in the four biggest cities of The Netherlands. Four peer educators per city (two Turks and two Moroccans) organised the AIDS education in turn or assisted with completing the questionnaire. Participation in the questionnaire was anonymous. Eight localities were matched (four experimental and four control settings) in every city per language group. One city failed to organise AIDS education for Moroccan inhabitants, which added up to 28 sessions for the experimental group and 28 sessions for the control group.

\subsubsection{Measures}

The format and phrases of the questionnaire were simple. The items had to be limited and a maximum of three answer categories was used. Complex formulations such as conditional statements were experienced as too difficult, e.g. "if you are in a situation where you have planned to raise the topic of condom use with your partner, would you...?'. Moreover, the questions had to be neutral. Explicit, suggestive references to sexual habits had to be avoided. The questionnaire was developed in collaboration with the peer educators. A certified agency translated the questionnaire into Turkish and Arabic. Native speakers translated the questionnaire back into Dutch.

The following background characteristics were raised:

Ethnic origin, age, marital status, duration of stay in The Netherlands, educational level, previous participation in AIDS education and the respondents' opinion on the importance of peer AIDS education in their native language. Factor analysis led to the following scales measuring perceived threat and beliefs about condom use. The scale 'misunderstandings regarding HIV transmission' consisted of three items, for example 'can the AIDS virus be transmitted by kissing?' $(\alpha=0.66)$. Risk appraisal for AIDS infection was asked using a six-item scale, for example 'can AIDS only be found in homosexual men?' ( $\alpha=0.61$ ). The scale 'benefit of the protective effects of condom use' included four items such as 'does a condom protect against the AIDS virus?' $(\alpha=0.56)$. Two items were used to measure the perceived barrier of diminished satisfaction with sex using a condom: 'making love using a condom is less satisfying' and 'making love using a condom is not genuine' ( $\alpha=0.62$ ). The barrier of buying condoms was measured using the item 'I find it difficult to buy condoms'. Self-efficacy was measured using one item: 'I know exactly how to use a condom'. Intention to use condoms was measured using one item: 'I think I will use a condom in the future if I have a new partner'.

\subsubsection{Analysis}

First, the result of the matching procedure was examined. Differences in background characteristics between the experimental and control groups were tested using the I test $(p<0.05)$. Response rates were established. The outcome measures were dichotomised. The scores on the questionnaire items were analysed at the level of individuals using the Chi-square test $(p<0.05)$. A multivariate analysis was conducted using multilevel logistic regression analysis because the observations were not independent. 
People visited the same locality, received education in the same group and shared the same peer educator. In short, they were more alike than members of other groups, which means that the measurements were correlated. Standard logistic regression does not account for this. The estimates of odds ratios (ORs) of multilevel logistic regression analysis are much like those of standard analysis; however, the standard errors were mostly somewhat higher, leading less often to rejection of the null hypothesis (Goldstein, 1995; Hox, 1995). All first-level background characteristics were included in the multilevel model as independent variables. Being a member of the experimental or control group was the key independent variable. Two-way interactions of this variable and the background characteristics were tested $(p<0.10)$ and added to the model if significant. Extra-binomial variation was also tested. Next to this model, a more extensive model was tested including the matching variables as second-level group characteristics in order to explain the second-level variation. ORs were tested using $95 \%$ confidence intervals (95\% $-\mathrm{Cls}$ ). The statistical packages SPSS for Windows and MLn were used. The most accurate method available in MLn was used (PQL, second order) (Rasbach \& Woodhouse, 1996).

\subsection{Results}

\subsubsection{Respons}

In total 24 pairs of localities could be matched with respect to nationality, type of locality, estimated mean age and assessment of degree of conservatism. The number of visitors was assessed by the peer educators which made estimates of response rates to the questionnaire possible. The estimated response' among the Turks in the experimental group was $54 \%$ and in the control group $40 \%$. The response among the Moroccans was $49 \%$ in the experimental group and $67 \%$ in the control group. The experimental and control groups did not differ significantly with respect to their background characteristics (table 1). Analysis per nationality showed a younger control group among Moroccans than the experimental group. The response group was fairly comparable to national census data with respect to age and marital status of male Turkish and Moroccan immigrants; however, the educational level of the response group was higher compared to data from national surveys among the immigrant groups.

\subsubsection{Effects}

The scores at the level of individuals per questionnaire item are given in table 2 . The experimental group differed significantly from the control group on the items concerning misunderstandings regarding HIV transmission. In the control group only half of the respondents gave the right answers to the questions as opposed to $70-80 \%$ of the respondents in the experimental group. In general, the experimental group gave the correct answers to the items about risk of AIDS more often than the control group. The scores on the items about the incubation time of HIV (feeling healthy when infected) and testing of prostitutes were still relatively low after attendance at the education session (experimental group). Most respondents already had positive beliefs about the protective effect of condom use. 


\begin{tabular}{|c|c|c|c|c|c|}
\hline & \multirow{2}{*}{\multicolumn{2}{|c|}{$\begin{array}{l}\text { Experimental group } \\
\qquad \mathrm{N}=293\end{array}$}} & \multicolumn{2}{|c|}{ Control group } \\
\hline & & & & & \\
\hline & & $\mathbf{N}$ & & $\mathrm{N}$ & $\%$ \\
\hline \multicolumn{6}{|l|}{ Age (Years) } \\
\hline & $<20$ & 26 & 10 & 48 & 17 \\
\hline & $20-29$ & 115 & 43 & 103 & 37 \\
\hline & $30-39$ & 86 & 32 & 83 & 30 \\
\hline \multicolumn{6}{|c|}{ Marital status } \\
\hline & Marries & 174 & 62 & 178 & 62 \\
\hline & Unmarried & 106 & 38 & 109 & 38 \\
\hline \multirow{4}{*}{ Education } & None & 17 & 10 & 17 & 6 \\
\hline & Primary & 81 & 29 & 86 & 30 \\
\hline & Secondary & 139 & 50 & 138 & 49 \\
\hline & Polytechnid University & 31 & 11 & 42 & 15 \\
\hline \multicolumn{6}{|c|}{ Duration of stay in } \\
\hline \multicolumn{6}{|c|}{ The Netheriands (yrs) } \\
\hline & $>3$ & 250 & 89 & 244 & 86 \\
\hline \multicolumn{6}{|c|}{ Former Aids education } \\
\hline & Yes & & 42 & 100 & 36 \\
\hline & & 162 & 58 & 180 & 64 \\
\hline \multirow{2}{*}{\multicolumn{6}{|c|}{$\begin{array}{l}\text { Importance attached to peer } \\
\text { education in the native language }\end{array}$}} \\
\hline & $\begin{array}{l}\text { Important } \\
\text { Impuage }\end{array}$ & 201 & 71 & 177 & \\
\hline & Neutral/ unimportant & 84 & 29 & 101 & 36 \\
\hline
\end{tabular}

However, the education showed an effect on the belief of the possibility of infection of a life partner when someone has extramarital sexual contacts not using a condom. A difference between the experimental and control group in answers on the items concerning the barrier of diminished satisfaction if using condoms, the barrier of buying condoms and self-efficacy and intention with respect to condom use could not be proven. When taking into account the background characteristics of the respondents and the level of groups in the multilevel logistic regression analysis an effect could again be established on misunderstandings regarding HIV transmission (OR=5.9 and $95 \%-\mathrm{Cl}$ : 2.3-15.3) and risk appraisal for AIDS infection (OR=2.9 and 95\%-Cl: 1.3-6.3). (table 3). An interaction effect was found between group membership and former attendance at AIDS education. The effect on misunderstandings and risk appraisal was highest among men who had not participated in AIDS education earlier (ORs 8.7 and 3.5); however, among men who had participated before, a significant effect could still be proven on misunderstandings regarding HIV trans mission (OR=3.5 and $95 \%-\mathrm{Cl}$ : $1.2-9.9$ ). An effect on targets related to expectancies with respect to condom use was absent in the multilevel analyses without interaction terms, except for the effect on self-efficacy which was almost significant $(\mathrm{OR}=1.8$ and $95 \%-\mathrm{Cl}: 1.0-3.4)$. When interaction terms were added to the regression models, the AIDS education was shown to be significantly effective in several subcategories. In the older men, i.e. 30 years and above, beliefs about the protective effect of condom use were more positive in the experimental group as compared to the control group. Moreover, an effect was found on the barrier of diminished satisfaction of condom use among unmarried men and on the self-efficacy of those who valued peer AIDS education in their native language as important. 
Table 2. Scores on the questionnaire items (E=experimental group, $\mathrm{C}=\mathrm{control}$ group)

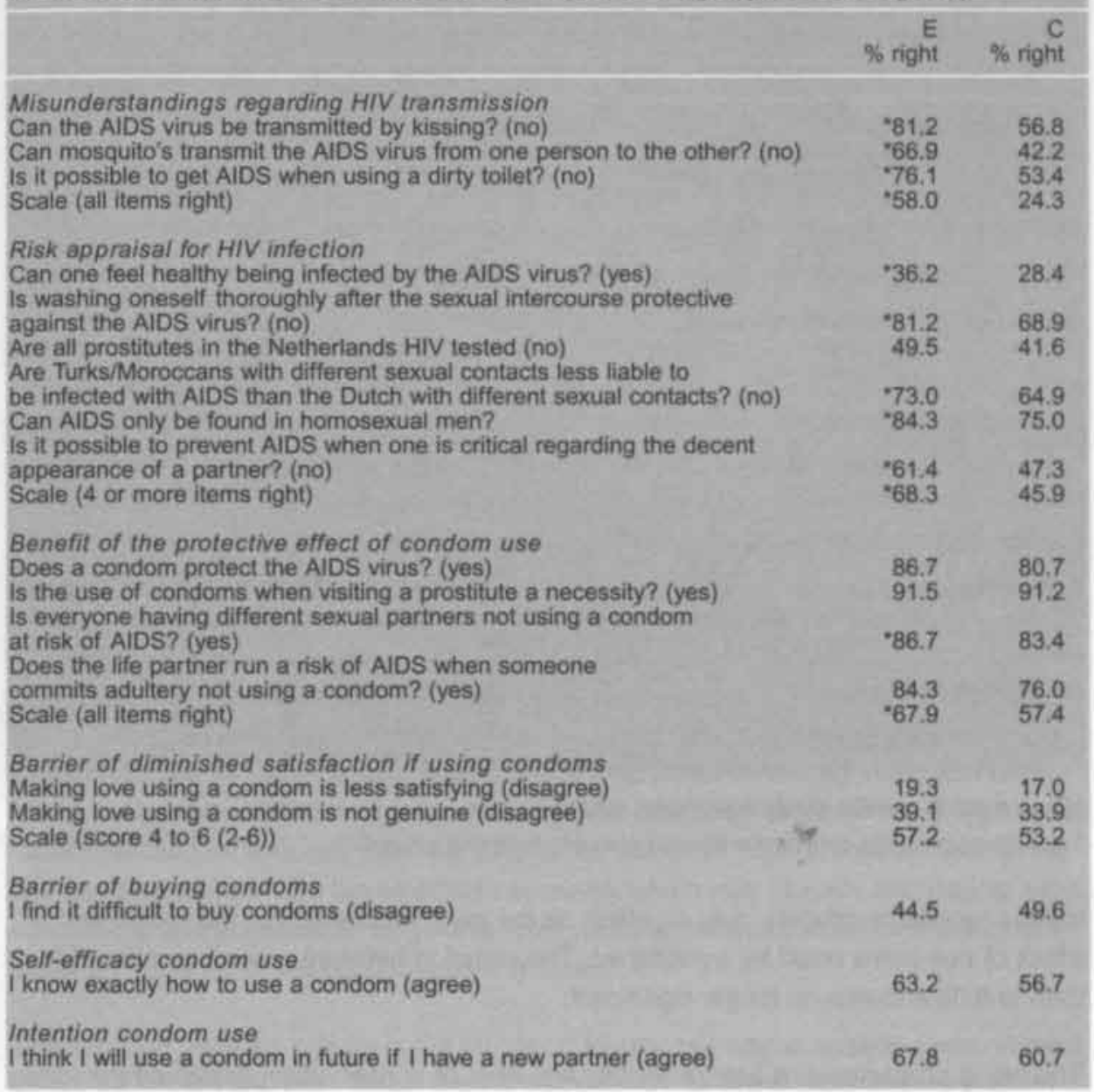

- Chi-square test: $p<0.05$

An interaction effect was found between nationality and group membership on the intention to use condoms in future with new partners. Moroccans who attended the AIDS education planned to use condoms more often than fellow Moroccans who had not yet followed the education session ( $O R=3.7$ ). Among Turks, participants of the AIDS education were less likely to use condoms than Turks who had not yet had the opportunity to participate $(O R=0.6)$. The education session failed to change the perceived barrier of buying condoms. Extra-binomial variation was absent in all multilevel logistic regression analyses. Therefore, this variation was restricted to unity in all models. The variation at group level, when only first-level variables were entered in the models, was, in most cases, significant, except for the barriers of diminished satisfaction and the buying of condoms (table 3 ). These latter outcome measures seemed to be explained by the characteristics of the individuals. When the second-level variables, that is type of locality, estimated mean age and level of conservatism, were added to the multilevel 


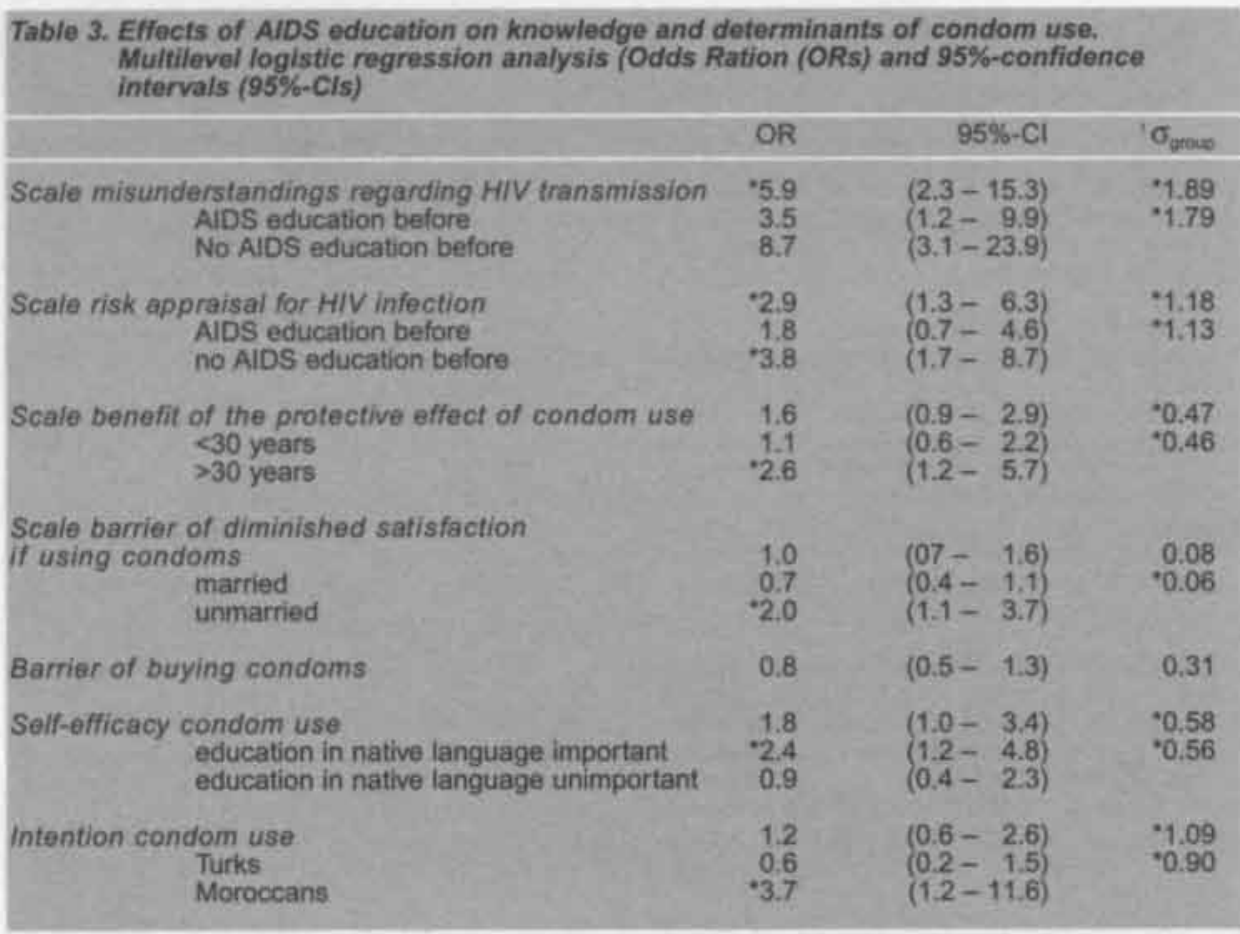

$\sigma_{\text {group }}=$ group specific variation (standard errors)

- significant $(p<0,05)$, confidence interval does not comprise value 1

logistic regression models, only an effect on the perceived benefit of the protective effect of con-doms could be established. The variation between groups decreased from 0.46 to 0.08 and was no longer significant.

The group characteristics type of locality and level of conservatism explained the variation in beliefs about condom prevention to a great extent. Beliefs were more positive in mosques and moderately conservative audiences and less positive among conservative audiences. The nationality of the respondents was treated as a first-level variable in the logistic regression models, though it could be viewed as a group characteristic. Turks and Moroccans differed significantly with respect to beliefs about the protective effect of condom use and self-efficacy towards condom use. More Moroccans than Turks had beliefs in the desired direction.

\subsection{Conclusion and discussion}

AIDS education for immigrants in The Netherlands given in their native language by peers was evaluated. Turkish and Moroccan men were trained to educate people from their own ethnic group. The aim of this peer AIDS education was to increase knowledge about transmission and prevention of AIDS, reduce unnecessary fears and misun- 
derstandings and change people's behaviour towards condom use. The effect of peer education on the perceived threat of AIDS and beliefs about condom use was studied. Beliefs and not actual behaviour were central in this study because questions about personal sexual behaviour had to be avoided. For instance, intention to use condoms was asked about as this is a predictor for undertaking the behaviour. The study design proved to be useful in the difficult setting of coffee houses, mosques and bars that are visited by men who are seldom asked to cooperate in a research project. The response to the questionnaire was satisfactory; however, poorly educated immigrants were underrepresented.

The AIDS education primarily had an effect on the perceived threat of AIDS. Misunderstandings with respect to the transmission of HIV were cleared up and the risk appraisal for AIDS infection improved. The effect was highest in men who had not received AIDS education before. The belief that condom use is beneficial in AIDS prevention was already widespread among the Turkish and Moroccan men. An educational effect was only achieved in the older age group. Positive feelings towards using condoms among the unmarried, who probably run a higher risk of HIV infection because of multiple sexual partners, is a hopeful outcome of AIDS education. The effect on selfefficacy shows that a positive attitude to-wards peer education is a requirement for a productive result. Approximately $65-70 \%$ of the audience thought it important to have education on AIDS in their native language by a peer. The presence of an effect on intention to use condoms among Moroccans and its absence among Turks was remarkable. A closer examination of the activities of the education sessions using registration forms showed that less attention was paid to the demonstration of condom use during the Turkish sessions than the Moroccan sessions, which may indicate that talking about condoms is less accepted among Turks. This could be an explanation for the lack of effect on intention to use condoms among Turks.

The variation between groups in the multilevel logistic regression analyses was, in most cases, significant and high, which means that differences in the experimental and control groups could be explained by group characteristics. These characteristics are unclear in most models. An effect of nationality, the type of locality, that is coffee house, mosque or otherwise and the degree of conservative or modern ideas among the audience could only be demonstrated with respect to beliefs about the protective effect of condom use. Moreover, the variation in self-efficacy across groups could be explained by nationality. More Moroccans than Turks rated condom self-efficacy high. This result is consistent with the modifying effect of nationality on the relationship between participation in AIDS education and intention to use condoms, as mentioned above. This means that the AIDS education programme has to take into account group characteristics such as nationality when condom-related targets are pursued.

The AIDS education programme was started in order to bridge the gap between the general mass media campaigns and the language problems of immigrant groups in The Netherlands. When considering the clearance of misunderstandings and the change of 
the appraisal of susceptibility to AIDS, peer education is seen as an appropriate alternative. In spite of these effects, some instruction is still necessary on the incubation time of HIV and the policy of testing of prostitutes. The behaviour change of getting all subgroups to use condoms remains a difficult task. The AIDS education of customers of coffee houses and visitors of mosques of 1 hour duration may have been too general and too brief to affect the complex mechanism of behaviour change. A discussion of sexual contacts with different partners, extramarital contacts and condom use turned out to be difficult in the Muslim culture of Turks and Moroc-cans. Research into the stages of change is recommended in order to realise behaviour change in all target groups. The message of the peer educator has to be adapted to people's needs. From the transtheoretical model of change it becomes clear that stressing the benefits of condom use is relevant the pre-contemplation and contemplation stage when the $s$ ubjective perception of cons related to condom use outweigh the pros. When people are ready to adopt and maintain a behaviour, the action is strongly related to selfefficacy. Promoting people's confidence in skills at that moment is very relevant (Grimley et al.,1997). For example, young immigrants who ex-periment with sexual contacts or unmarried immigrants who have different sexual partners may be open to the message of condom use. Strategies should be developed in order to change their beliefs and self-efficacy. For the audience which is not yet ready to consider condom use, successful communication attracting attention and improving comprehension of HIV transmission and preventive methods is recommended (Fischer et al.,1994; McGuire, 1985).

This evaluation study makes clear that continuation of peer education in native language is to be recommended. Continuous and careful discussion within migrant groups on condom use in order to break the taboo in their cultures is relevant. An effect on misunderstandings could still be proven in people who had previously attended AIDS education sessions, which proves the necessity of repeating the message of AIDS prevention in immigrant groups. 


\section{References}

Bandura, A. (1986). Social foundations of thought and action: a social cognitive theory. Englewood Cliffs. New Jersey. Prentice Hall.

Bandura, A. (1994), Social cognitive theory and exercise of control over HIV infection. In: DiClemente, R.J., Peterson, J.L., editors. Preventing AIDS: theories and methods of behavioral interventions. New York. Plenum Press, 25-59.

Brugman, E., Vogels, T., Zessen, G. van. (1997). Trends in sexual risk behaviour among Turkish/Moroccan adolescents in The Netherlands 1990-1995. Eur J Public Health 7, 418-20.

Coates, T.J., Collins, C. (1998). Preventing HIV infection: altering behavior is still the primary way to control the epidemic. Sc Am 279(1), 76-7.

Duifhuizen, R. van. HIVIAIDS prevention programmes for migrants and ethnic minorities in Europe: a challenge for policy makers, NGO's and health educators. In: Haour-Knipe, M., Rector, R., eds. Crossing borders: migration, ethnicity and AIDS. Bristol: Taylor \& Francis. (1996). 118-35.

Duifhuizen, R. van, Bröring, G. editors. (1993). AIDS and mobility: a manual for the implementation of HIVIAIDS prevention activities aimed at travellers and migrants. Amsterdam NCAB.

Eng, E., Parker, E., Harlan, C. (1997). Lay health advisor intervention strategies: a continuum from natural helping to paraprofessional helping. Health Educ Behav 24, 413-7.

Everaert, H.A., Lamur, H.E. (1993). Alles wat geheim is, is lekker: seksuele relaties en beschermingsgedrag van Turkse mannen (Secret things are pleasant: sexual relationships and protective behaviour among Turkish men). Amsterdam: Het Spinhuis.

Fishbein, M., Ajzen, L. (1975). Belief, attitude, intention and behaviour: an introduction to theory and research. Reading. MA. Addison Wesley.

Fisher, J.D., Fisher, W.A., Williams, S.S., Malloy, T.E. (1994). Empirical tests of an information-motivation-behavioural skills model of AIDS-preventive behaviour with gay men and heterosexual university students. Health Psychol 13, 238-50.

Gelder, P., Lamur, H.E. (1993).Tussen schaamte en mannelijkheid: seksuele relaties en beschermingsgedrag onder Marokkaanse mannen (Between shame and masculinity: sexual relationships and protective behaviour among Moroccan men). Amsterdam. Het Spinhuis.

Goldstein, H. (1995). Multilevel statistical mode/s, 2nd edn. London. Kendall's Library of Statistics.

Green, L.W., Kreuter, M.W. (1991). Health promotion planning: an educational and environmental approach. Mountain View. Mayfield.

Grimley, D.M., Prochaska, G.E., Prochaska, J.O. (1997). Condom use adoption and continuation: a transtheoretical approach. Health Educ Res 12, 61-75. 
Haastrecht, P. van. (2000). AIDS education in minority languages and cultures: a vital strategy. Dutch Soa Bull 20, 26-9.

Hoek, J.A.R. van den, Coutinho, R.A. (1994), Seksueel overdraagbare aandoeningen, HIV en AIDS bij migranten ( Sexually transmitted diseases, HIV and AIDS among immigrants). Ned Tijdschr Geneesk 138(21), 88-92.

Hooykaas, C., Velde, F.W. van der, Linden, M.M.D. van der, Doornum, G.J.J. van, Coutinho, R.A.. (1991). The importance of ethnicity as a risk factor for STDs and sexual behaviour among heterosexuals. Genitourin Med 67, 378-83.

Hox, J.J. (1995). Applied multilevel analysis, 2nd edn. Amsterdam. TT Publications.

Janz, N.K., Becker, M.H. (1984). The health belief model: a decade later. Health Educ Quart 11, 1-47.

Laar, M.J.W. van der, Sleutjes, M.P.M., Postema, C.A., van, (1991). Groups: an exploratory study. Ned Tijdschr Geneesk 135, 1542-7.

McGuire, L.W. (1985). Attitudes and attitude change. In: Lindsay G, Aronson E, editors. The handbook of social psychology. Vol. 2. New York. Random House 233-346.

Nutbeam, D., Harris, E. (1998). Theory in a nutshell: a practioner's guide to commonly used theories and models in health promotion. Sydney. National Centre for Health Promotion.

Pulley, L., McAllister, A.L., Kay, L.S., O'Reilly, K.. (1996) Prevention campaigns for hard-toreach populations at risk for HIV infection: theory and implementation. Health Educ Quart 23, 488-96.

Rasbach, J., Woodhouse, G. (1996), MLn command reference. Multilevel models project. London: Institute of Education University of London.

Rogers, E. (1983). Diffusion of innovations. New York. Free Press.

Rosenstock, I.M., Strecher, V.J., Becker, M.H. The health belief model and HIV risk behavior change. In: DiClemente, R.J., Peterson, J.L. editors. (1994). Preventing AIDS: theories and methods of behavioural interventions. New York. Plenum Press. 5-24.

Ven, A.H., Delbecq, A.L.. (1972). The nominal group as a research instrument for exploratory health studies. Am J Public Health 62, 337-42. 


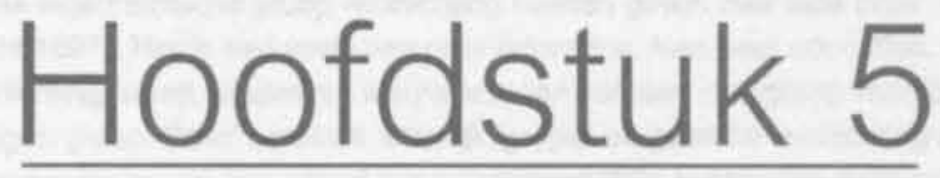

Opvattingen over voorlichting en de voorlichter in de eigen taal bij Turkse en Marokkaanse mannen na voorlichting over aids. 


\section{Summary}

\section{Beliefs about health education and the peer educator of Turkish and Moroccan men after an Aids education session.}

Since 1989 Aids education in Holland has been given by migrant peer health educators. Migrant men (Turkish and Moroccan) are being trained to carry out aids education sessions with their own ethnic group. Assumed is that these health educators fulfil a need of the target group, and that the target group appreciates the health education in their own language and according to their own cultural background. Presumed is that the health educator stands close to the target group, and that he can be a role model for his 'peers'. This also should be the case with a controversial subject like Aids. It is conceivable that the role model is being 'stained' or 'contaminated' with the subject of the education. And as a result the opinion of the target group about the health educator will be influenced in a negative way. In this process evaluation is being established that three quarters of the respondents have the opinion that speaking Turkish (Moroccan) by the peer educator and knowing the Turkish (Moroccan) culture is important. The Turks and Moroccans don't differ in that respect. There is also no difference in the perceived reliability of the peer educator. But they do differ in respect to the preference for a Dutch health educator or a peer educator. Most Moroccan prefer a Dutch educator; most Turks prefer the peer educator. All these results are not changed by controlling for age, marital status, educational level and the openness of the aids education session. The Moroccans see the aids educator more often as a role model than the Turks. But that is only the case for the respondents that experienced 'closed' sessions, in which the use of condoms is not extensively dealt with. There is no difference in the 'open' sessions. 


\section{Opvattingen over voorlichting en de voorlichter in de eigen taal bij Turkse en Marokkaanse mannen na voorlichting over aids.}

\subsection{Inleiding}

In 1988 is het Project Voorlichting Eigen Taal en Cultuur (VETC) van start gegaan.

Binnen dit project worden migranten opgeleid tot aidsvoorlichter, waarna ze in de eigen taal aan de eigen etnische groep voorlichting kunnen geven over aids (Van

Haastrecht,1997). Het is een vorm van peer education. Van peer education, of voor-endoor voorlichting, wordt gesproken wanneer leden van een doelgroep voorlichting geven aan de eigen groep. 'Peer' betekent letterlijk 'gelijke' en geeft bij voorlichting aan dat de voorlichter en doelgroep een aantal gemeenschappelijke kenmerken hebben, bijvoorbeeld een gelijke leeftijd, sociale klasse of een etnische achtergrond. Verwacht wordt dat de voorlichting gegeven door 'peers' door de overeenkomst een groter effect sorteert. De voorlichters van het VETC-project delen de kenmerken taal, cultuur, etniciteit, geslacht en migrant zijn met de doelgroep. Van potentiële voorlichters wordt voldoende opleidingsniveau gevraagd, zodat dat zij de cursus tot aidsvoorlichter in het Nederlands kunnen volgen. In de praktijk zijn de voorlichters dan ook beter opgeleid dan de doelgroep. Om effectief als peer-voorlichter te kunnen werken moet de voorlichter een 'primus inter pares' zijn: hij moet iemand zijn met wie de doelgroep zich in 'opwaartse zin' kan vergelijken. Hij moet een aantrekkelijk, nastrevenswaardig rolmodel zijn, die in de groep een wijgevoel kan oproepen. Dat wijgevoel wordt in de aids-voorlichting door de voorlichter gebruikt om zo overtuigend en motiverend mogelijk te zijn. Vanwege het onderwerp, in dit geval Aids, kan het ook gebeuren dat de identificatie met de voorlichter minder wordt, dat men bijvoorbeeld 'niks te maken wil hebben met iemand die verboden seks propageert'. Die voorlichter zal dan geen rolmodel meer zijn. Mensen streven naar consensus met 'gelijke' anderen. Wanneer er geen overeenstemming is, kan men óf de eigen mening aanpassen óf proberen de mening van degene met de afwijkende mening te veranderen (Koomen, 1992). Wanneer de peer educator als gelijke wordt beschouwd, zal men de eigen mening vergelijken met die van de voorlichter. Wanneer deze consistent en met zelfvertrouwen een afwijkende mening verkondigt, zal men op zijn minst tot twijfel gebracht worden en op den duur overtuigd raken van de juistheid van de opvattingen van de voorlichter (Meertens, 1992). Maar het omgekeerde kan ook het geval zijn. Door het gedrag van de peer-voorlichter, bijvoorbeeld door het gebruik van te expliciete taal rond seks, kan er cognitieve dissonantie ontstaan. Eén manier voor de deeinemer aan de voorlichting om daarin evenwicht te brengen, is zijn mening over de voorlichter bij te stellen. 'Ik ben blijkbaar niet zoals hij, en wil ook niet zo zijn!'

Eerder is gerapporteerd over het onderzoek naar de effectiviteit van de aidsvoorlichting bij Turkse en Marokkaanse mannen. In een quasi-experimenteel design werden koffiehuizen gematcht en 'at random' toegewezen aan de experimentele of controlegroep. 
Bij de helft van de locaties werd bij de bezoekers achteraf en bij het andere helft van de locaties vooraf aan de voorlichting een quiz afgenomen. Aangetoond werd dat de aidsvoorlichting een effect heeft op de ervaren dreiging van aids, op de misverstanden met betrekking tot aids en op de risicoperceptie. Alleen bij mannen ouder dan 30 was er een effect bij de voordelen van condoomgebruik; bij getrouwde mannen was er een effect op de barrière van verminderde satisfactie met een condoom, en de intentie tot condoomgebruik was alleen bij Marokkanen na de voorlichting positiever (Kocken e.a., 2001). In de quiz werd aan de respondenten óók gevraagd naar opvattingen over voorlichting in de eigen taal in het algemeen, en over de voorlichter. Nagegaan kan worden of er een verschil tussen Turken en Marokkanen bestaat met betrekking tot de opvattingen over de voorlichter en de voorlichting. De aidsvoorlichter beoordeelt voor elke concrete voorlichtingssituatie welke elementen hij in de voorlichting opneemt. Bij de voorlichting in de koffiehuizen speelt altijd de vraag hoe 'open en bloot' de voorlichting kan, en of er een condoomdemonstratie kan plaatsvinden. Een condoomdemonstratie of het gebruik van té open termen kan het beeld dat de doelgroep heeft van de voorlichter negatief beïnvloeden. Daarmee zou dus een averechts effect worden bereikt: de voorlichting zal bij die groep waarschijnlijk niet effectief zijn, en mogelijk wordt de voorlichter voor een ander onderwerp ook 'onbruikbaar'. Het is daarom interessant om na te gaan of de opvattingen over de voorlichter en de voorlichting verschillen tussen de respondenten die wel of geen 'open' voorlichting hebben meegemaakt. De vraagstelling is: Hoe beoordelen de Turkse en Marokkaanse mannen de voorlichting in de eigen taal en de aidsvoorlichter? Is er een verschil tussen de cultuurgroepen? Maakt het uit of de voorlichter open omgaat met het onderwerp condoomgebruik, of niet?

\subsection{Methode: praktijk van de Aidsvoorlichting}

Aan Turkse en Marokkaanse mannen worden éénmalige bijeenkomsten over Aids in koffie - of theehuizen en moskeeverenigingen gegeven. De bijeenkomst verloopt als volgt: de voorlichter vraagt de aandacht, stelt zichzelf voor en nodigt de aanwezigen uit om de voorlichting over Aids bij te wonen. Vervolgens geeft hij, meestal aan de hand van foto's op posterformaat, een diaserie of soms een videoband, informatie over Aids. Daarna is er ruimte om vragen te stellen en indien mogelijk geeft de voorlichter een condoomde-monstratie. Materiaal zoals folders, audiobandjes en condooms mag men gratis meenemen. Vaak volgt er nog een discussie met belangstellenden of wil iemand een individueel gesprek met de voorlichter.

De voorlichters zijn ten behoeve van het onderzoek in tweetallen naar de plaats van de voorlichting gegaan. Eén voorlichter droeg de verantwoordelijkheid voor de voorlichting: hij bereidde de voorlichting voor, gaf de informatie, beantwoordde vragen en leidde de discussie. De tweede voorlichter ging mee om de vragenlijst te introduceren en af te nemen. De anonimiteit van de respondenten werd gewaarborgd, mede doordat men het ingevulde formulier in een doos kon deponeren. De respondenten vulden de vragenlijst zelfstandig in. Indien men moeite had met de vragenlijst bood de tweede voorlichter 
hulp door de vragen voor te lezen, per tafel of plenair. Voorafgaand aan het onderzoek hebben de voorlichters een instructieochtend over de afname van de vragenlijst bijgewoond. Op deze wijze werd bevorderd dat de afname van de vragenlijst telkens op dezelfde wijze zou plaatsvinden. De procedure is bij drie voorlichtingsbijeenkomsten uitgetest: in twee Turkse koffiehuizen en in één Marokkaans koffiehuis. Hierbij bleek dat de afname van de vragenlijst problema-tisch werd als er meer dan 20 personen aanwezig waren. Daarom is aangeraden om de voorlichtingsbijeenkomst niet op de drukste momenten te plannen.

In deze analyse worden de nametingen uit een effectevaluatieonderzoek gebruikt (Kocken e.a., 2001). Er is gerandomiseerd op groepsniveau. In vier steden werden koffiehuizen via matching over de experimentele condities verdeeld. Randomisatie op individueel niveau was niet mogelijk omdat de voorlichting in een 'open' ruimte gegeven werd, waarmee bedoeld wordt dat iedereen naar behoefte kan binnenkomen of weggaan. De ene groep kreeg vooraf aan de voorlichting een vragenlijst voorgelegd, de andere achteraf. De groepen hadden gelijke kenmerken wat betreft Turkse of Marokkaanse gelegenheid, leeftijdsgroep (jong, oud of gemengd publiek) en mate van conservatisme (progressief, behoudend, gematigd of onbekend). De voorlichters kregen op basis van toeval aangewezen waar de voormeting en waar de nameting moest plaatsvinden. In veertien Turkse en in tien Marokkaanse koffiehuizen zijn de nametingen gedaan waarop deze analyse is uitgevoerd.

De vragenlijst werd aangeduid als een 'quiz' teneinde de drempel van deelname aan het onderzoek te veriagen. De vragenlijst kon vanwege het karakter van de voorlichting en vanwege het (verwachte) opleidingsniveau niet te lang en ingewikkeld worden.

Hierdoor komen slechts een beperkt aantal onderwerpen en vragen per onderwerp aan bod. Ook de antwoordcategorieën zijn daarom beperkt in de keuzemogelijkheden. Om zicht te krijgen op het belang dat de respondenten hechten aan voorlichting in de eigen taal en cultuur zijn vragen gesteld over de kenmerken van de voorlichting: "Ik vind het belangrijk dat de voorlichter Turks (of Marokkaans) spreekt" en "Ik vind het belangrijk dat de voorlichter de Turkse (Marokkaanse) cultuur kent". Er is gevraagd of men liever voorlichting zou krijgen van een Nederlander met een tolk. Daarnaast zijn twee items in de analyse gebruikt die kenmerken van de voorlichter omschrijven: "Ik vertrouw de aidsvoorlichter", en "De aidsvoorlichter is een voorbeeld voor mij". In totaal zijn er dus vijf afhankelijke variabelen gebruikt. De achtergrondvariabelen van de respondenten in deze analyse zijn de etniciteit (Turks of Marokkaans), verblijfsduur in Nederland, leeftijd, opleidingsniveau en burgerlijke staat. Over elke voorlichtingsbijeenkomst werd door de voorlichter een registratieformulier ingevuld, waarbij onder andere kon worden aangegeven welke leerdoelen in welke mate aan bod zijn gekomen. Zo kon een dichotomie worden gemaakt van de voorlichtingen waarbij wel of niet open over de techniek van condoomgebruik was gesproken, eventueel met condoomdemonstratie.

In de analyse is gebruik gemaakt van SPSS onder Windows. Kruistabellen zijn getoetst met de Chi-kwadraattoets. Er zijn multipele regressie analyses uitgevoerd, met de opvatting over de voorlichting en voorlichter als afhankelijke variabele en etniciteit als 
determinant (model 1). Vervolgens is de regressievergelijking, gecontroleerd voor leeftijd, burgerlijke staat en opleiding (model 2), en openheid van de voorlichting (model 3 ).

\subsection{Resultaten}

In Tabel 1 is nagegaan in hoeverre de respondenten representatief genoemd kunnen worden voor de Turkse en Marokkaanse mannen in Nederland. Vergeleken met de algemene bevolking van de Turken en Marokkanen in Nederland zijn in de onderzoeksgroep de oudere Turken iets ondervertegenwoordigd. Het opleidingsniveau van de onderzoeksgroep is iets hoger voor zowel de Turkse als Marokkaanse mannen.

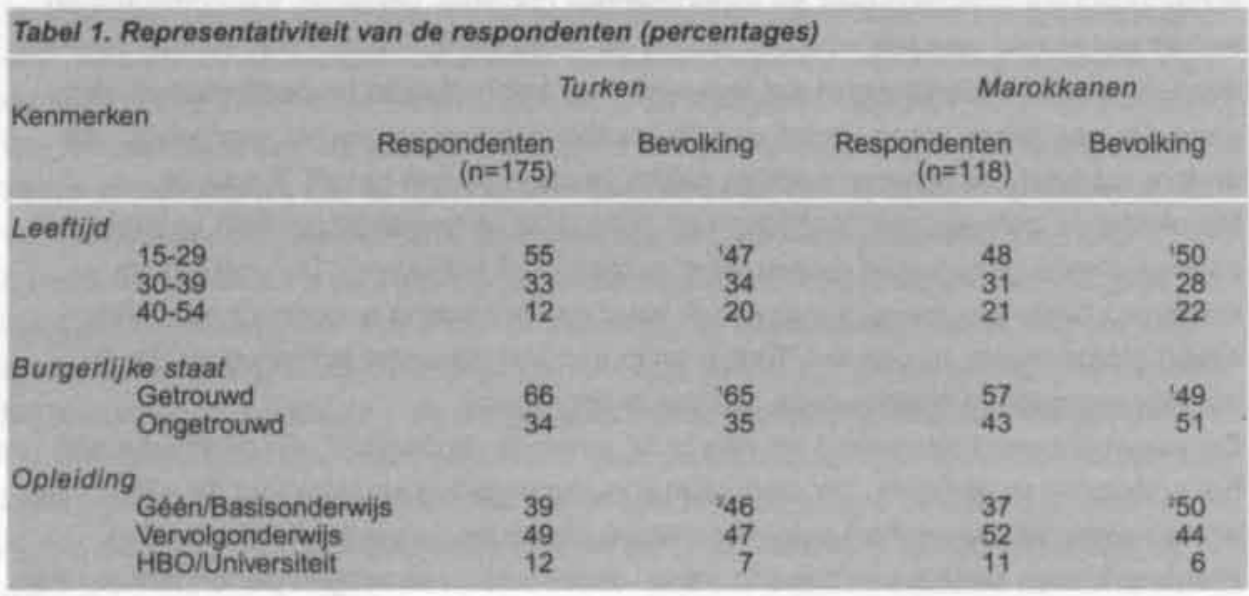

1 Bron: CBS, Maandstatistiek van de bevolking 1998; maart: 26-33

2 Bron: Enquête beroepsbevolking, In: CBS; Allochtonen in Nederland, 1998. Voorburg/Heerlen. 1998.

In tabel 2 wordt een overzicht gegeven van achtergrondkenmerken van de respondenten verdeeld naar etniciteit. Er is een verschil in de leeftijdsopbouw van de Turkse en Marokkaanse groep $\left(\chi^{2}=14,7 ; p=0,002\right)$. De Marokkaanse respondenten zijn ouder. Bij de Turken is de leeftijdsgroep 25-34 jaar sterk vertegenwoordigd. Verder blijkt uit de registratie van de voorlichters dat de openheid van de voorlichting bij de Marokkanen groter is geweest dan bij de Turken $\left(\chi^{2}=21,6 ; p=0,000\right)$.

Tabel 3 geeft een beeld over de opvattingen over de voorlichting en voorlichter. In de meeste gevallen is er weinig verschil tussen de Turkse en Marokkaanse respondenten. Ruim driekwart van alle respondenten vindt het belangrijk dat de voorlichter de eigen taal spreekt, en dat de voorlichter de eigen cultuur kent. lets minder Marokkanen dan Turken vinden het van belang dat de voorlichter de eigen taal spreekt maar het verschil is niet significant. Datzelfde beeld is er bij het belang van de kennis van de eigen cultuur. Vervolgens is gevraagd naar de voorkeur voor aidsvoorlichting door een Nederlander met een tolk. lets meer dan de helft van de respondenten geeft de 
Tabel 2. Achtergrondkenmerken van de respondenten naar etniciteit.

\begin{tabular}{|c|c|c|c|}
\hline \multicolumn{2}{|l|}{ Kenmerken } & Turks $n(\%)$ & Marokkaans $n(\%)$ \\
\hline leeftiid & & $175(100)$ & $118(100)$ \\
\hline & $\begin{array}{l}<24 \text { jaar } \\
25-34 \\
35-44 \\
>45\end{array}$ & $\begin{array}{r}44(28) \\
80(51) \\
25(18) \\
7(6)\end{array}$ & $\begin{array}{r}34(30) \\
39 \\
20 \\
19\left(\begin{array}{l}35 \\
18 \\
17\end{array}\right)\end{array}$ \\
\hline Burgerlijke & $\begin{array}{l}\text { taat } \\
\text { Getrouwd } \\
\text { Ongetrouwd }\end{array}$ & $\begin{array}{r}110(66) \\
57(34)\end{array}$ & $\begin{array}{l}49(57) \\
49\left(\begin{array}{l}53\end{array}\right)\end{array}$ \\
\hline Opleiding & $\begin{array}{l}\text { Geen } \\
\text { Basisonderwijs } \\
\text { Vervolgonderwijs } \\
\text { HBO/Universiteit }\end{array}$ & $\begin{array}{l}11(7) \\
56(33 \\
82 \\
20(12) \\
20\end{array}$ & $\begin{array}{l}16(15) \\
25(23) \\
57(52) \\
11(10)\end{array}$ \\
\hline Duur verbli & $\begin{array}{l}\text { in Nederland } \\
0-3 \text { jaar } \\
4>\text { jaar }\end{array}$ & $\begin{array}{r}21(12) \\
148(88)\end{array}$ & $\begin{array}{r}9(8) \\
102(92)\end{array}$ \\
\hline Openheid & $\begin{array}{l}\text { de voorlichting } \\
\text { Open } \\
\text { Gesioten }\end{array}$ & $\begin{array}{l}81(54) \\
94(46)\end{array}$ & $\begin{array}{r}* 87(73) \\
31(26)\end{array}$ \\
\hline
\end{tabular}

voorkeur aan de voorlichter. Velen geven dus de voorkeur aan een Nederlander met een tolk. Daarbij blijkt een groot verschil te bestaan tussen Turken en Marokkanen. Bij Turken geeft de meerderheid de voorkeur aan een voorlichter, bij Marokkanen geeft de meerderheid juist de voorkeur aan een Nederlander met een tolk. Het vertrouwen dat men heeft in de voorlichter verschilt niet tussen Turken en Marokkanen: driekwart heeft vertrouwen in de voorlichter. Maar of men de voorlichter een voorbeeld voor zichzelf vindt, daarover verschillen de Turken en Marokkanen wel van mening. Minder Turken $(58 \%)$ dan Marokkanen ( $70 \%$ ) vinden de voorlichter een voorbeeld voor zichzelf. In de regressieanalyse met 'voorlichter als voorbeeld' als afhankelijke variabele blijkt er een interactie tussen de openheid van de voorlichting en etniciteit. Alléén bij de voorlichtingen waarbij het condoomgebruik in bedekte termen is besproken, vinden de Turken de voorlichter minder een voorbeeld voor zichzelf dan de Marokkanen $(\beta=-0,23 ; 95 \%$ betrouwbaarheidsinterval: $-0,77--0,05$ ). Bij de deelnemers aan een 'open' bijeenkomst is er geen verschil tussen Turken en Marokkanen.

\subsection{Discussie}

De meeste Turkse en Marokkaanse mannen in de koffiehuizen van Amsterdam,

Rotterdam, Den Haag en Utrecht vinden het belangrijk dat de voorlichter hun eigen taal spreekt en hun eigen cultuur kent. Dat is een bemoedigend gegeven voor de voorlichting in de eigen taal. Het aanbod van de voorlichting in de eigen taal voldoet aan 


\begin{tabular}{|c|c|c|c|c|}
\hline Opvattingen (bereik 1-3) & $\begin{array}{r}\text { Positief } \\
\mathrm{n}(\%)\end{array}$ & $\begin{array}{r}\text { 'Neg.Neutraal } \\
\mathbf{n}(\%)\end{array}$ & 'Gem. verschil & $95 \%-b$. \\
\hline Turks/Marokkaans spreken belangrijk? & $228(78)$ & $62(22)$ & 0.11 & $(-0,048-0,26)$ \\
\hline $\begin{array}{l}\text { Turkse/Marokkaanse cultuur } \\
\text { kennen belangrijk? }\end{array}$ & $226(79)$ & $60(21)$ & 0,03 & $(-0.11-0.18)$ \\
\hline Liever een Nedertander met tolk? & $153(53)$ & $133(47)$ & 0.25 & $*(0,075-0,42)$ \\
\hline Vertrouwen in de voorlichter? & $219(77)$ & $67(23)$ & $-0,02$ & $(-0,16-0,12)$ \\
\hline Voorlichter is voorbeeld? & $180(63)$ & $105(37)$ & $-0,19 \cdots$ & $\cdots(-0,38--0,02)$ \\
\hline
\end{tabular}

1 Percentage positieve antwoorden

2 Percentage negatieve of neutrale antwoorden

3 Gemiddelde verschil tussen Turken en Marokkanen, gecontroleerd voor leeftijd, burgerlijke staat en opleiding.

4 Het $95 \%$ betrouwbaarheidsinterval

- Marokkanen hebben significant vaker liever een tolk

* Turken oordelen hier significant negatiever dan Marokkanen

een behoefte. Marokkanen geven méér dan de Turken de voorkeur aan voorlichting door een Nederlander met een tolk in plaats van door een aidsvoorlichter in de eigen taal. In de praktijk van de migrantenvoorlichting blijkt dat voorlichtingsgroepen voor Marokkanen moeilijker tot stand komen en minder goed bezocht worden dan de voorlichtingsbijeenkomsten voor Turken. Mogelijk is de voorkeur voor een tolk een deel van de verklaring voor dit verschil. Een andere verklaring voor dit verschil is het probleem van de dialecten. De Marokkanen die Berber spreken zullen de voorlichter die Marokkaans - Arabisch spreekt met moeite verstaan, en andersom. Bij de vraag over het vertrouwen in de voorlichter (Die heeft men dus net zien optreden!) blijkt er geen verschil tussen Turken en Marokkanen. De 'voorlichter als voorbeeld' laat echter een duidelijk verschil zien. Alleen bij de voorlichtingsbijeenkomsten waarbij het condoomgebruik beperkt en in bedekte termen behandeld is, zien de Turken hun voorlichter minder als voorbeeld dan de Marokkanen. Over de richting van deze samenhang kan op basis van deze gegevens niets geconcludeerd worden. Het is mogelijk dat de Turken gevoeliger zijn voor de opstelling van de voorlichter, en dat de bedekte bespreking van het condoomgebruik ertoe leidt dat men de voorlichter niet als voorbeeld ziet. De Turkse voorlichter is dan blijkbaar té voorzichtig geweest. Het kan ook zijn dat de voorlichter weinig aansluiting voelt bij het publiek, en zich minder een voorbeeld voelt, en als resultaat daardoor méér bedekte termen gaat gebruiken. Bij dit voorlichtingsproces is er veel interactie en zal er sprake zijn van een wisselwerking tussen voorlichter en gehoor. Het is waarschijnlijk dat beide processen tegelijkertijd spelen. Er is tot nu toe weinig aandacht voor de mogelijke wederzijdse invloed van het onderwerp van de voorlichting, de wijze van voorlichten en de gepercipieerde kenmerken van de voorlichtingsbron, in dit geval de aidsvoorlichter. Het zou goed zijn om in evaluatie-onderzoek steeds aandacht te besteden aan de vraag of hier sprake is van bevorderende of belemmerende factoren. 


\section{Literatuur}

Haastrecht, P van. (1997). Project Ontwikkeling Aids-voorlichting aan migranten. Jaarver-slag 1996. Woerden. NIGZ.

Kocken, P.L., Voorham, A.J.J., Brandsma, J., Swart, W.A.J.M. (2001) Effects of peer-led Aids-education aimed at Turkish and Moroccan migrants in the Netherlands: a randomized controlled evaluation study. Europ J Public Health; 11; 2: 153-9

Koomen, W. (1992). Sociale cognitie: attributie, zelfbeeld en juistheid van indrukken. In: Meertens, R.W., Grumkow, J. von (red.), Sociale Psychologie. Groningen. Wolters Noordhof.

Meertens, R.W. (1992). Beïnvloedingsprocessen in groepen. In: Meertens, R.W., Grumkow, J. von (red.), Sociale Psychologie. Groningen. Wolters Noordhof. 



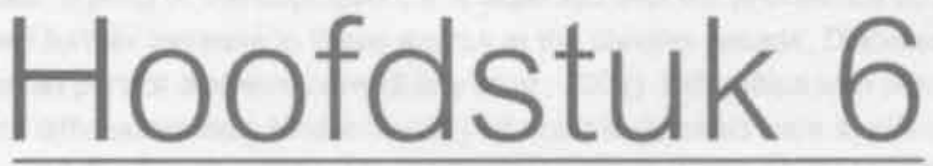

Ethnic-specific diabetes education for Turkish type 2 diabetics: a controlled study in general practice 


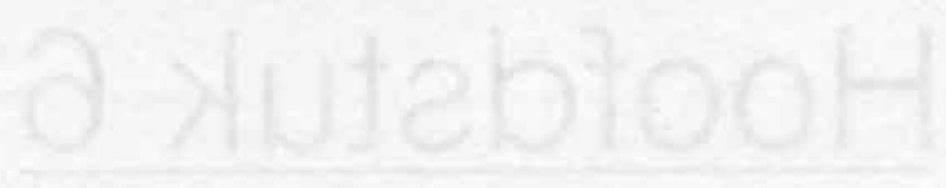

\section{Abstract}

In Turkish immigrant diabetics difficulties with communication and cultural differences may hinder delivery of optimal diabetes care by their general practitioner. The objective of the study is to assess the effect of an ethnic-specific diabetes education program on glycaemic control and cardiovascular risk factors in Turkish type 2 diabetes patients. In a prospective controlled study, Turkish immigrant diabetics who were offered routine care plus ethnic-specific diabetes education given by bicultural Turkish female educators, were compared with Turkish diabetics offered routine care only (control group). From December 1997 to December 1999, 104 Turkish type 2 diabetes patients were recruited in sixteen general practices ( 31 GPs) in Rotterdam, of which 85 could also be assessed at one-year follow-up. The main outcome measures were glycaemic control, lipid concentrations, blood pressure and body mass index. Compared with the control group, mean $\mathrm{HbA} 1 \mathrm{c}$ in the intervention group decreased by $0.3 \%$ ( $95 \% \mathrm{Cl}:-0.8$ to 0.2 ). A significant decrease in $\mathrm{HbA1c}$ was observed in women with $\mathrm{HbA} 1 \mathrm{c}>7 \%$ at baseline $(-0.9 \% ; 95 \% \mathrm{Cl}-1.73$ to -0.09$)$ but not in the other subgroups studied. Serum lipid concentrations, blood pressure and body mass index remained unchanged in the intervention group. Concluded is that ethnic-specific diabetes education by Turkish female educators has no obvious beneficial effect on glycaemic control or the cardiovascular risk profile. More focus on specific patient selection and gender equality between educators/ patients may prove worthwhile. 


\section{Ethnic-specific diabetes education for Turkish type 2 diabetics: a controlled study in general practice}

\subsection{Introduction}

Type 2 diabetes has a high prevalence among ethnic groups in Western society (Marshall et al., 1993; Cowie et al.,1993; Carter et al.,1996; Weijers et al., 1998). Together with ageing of the population, it is expected that the prevalence of type 2 diabetes will further increase in these groups in the coming decade. Diabetes education is an essential part of diabetes care (Elasy et al., 2001). Difficulties with communication and cultural differences may hinder delivery of optimal diabetes care to ethnic groups (Hawthorn and Tomlinson, 1999). The Turkish population is one of the largest ethnic minority groups in the Netherlands. Most of the older Turkish inhabitants are first generation immigrants who came to the Netherlands in the 1960 s and 1970 s. They live in a relatively traditional manner and their proficiency in the Dutch language is limited. Although empirical data are scarce, the available data show that the prevalence of type 2 diabetes in the Turkish population is higher than in the indigenous Dutch population and, that compared to Dutch type 2 diabetes patients, glycaemic control in Turkish diabetics is poorer (Weijers et al, 1998; Uitewaal et al., 2003). We developed an ethnicspecific, tailor-made education program for Turkish diabetes patients (treated by their GP in general practices) carried out by Turkish female educators. This study assessed whether the diabetes education program ha a beneficial effect on glycaemic control and cardiovascular risk factors in Turkish type 2 diabetes patients.

\subsection{Patients and Method}

The study followed a prospective controlled experimental design. Turkish type 2 diabetes patients from seven practices (13 GPs) in the southern part of Rotterdam formed the intervention group and were offered routine care together with ethnic-specific diabetes education. For the control group Turkish type 2 diabetes patients were recruited from nine practices (18 GPs) located in a comparable from ethnic and socio-economic area in the northern part of Rotterdam, who were offered routine care only. Approval for this study was obtained from the Ethics Committee of the Erasmus Medical Centre Rotterdam.

\section{Patients}

All Turkish type 2 diabetes patients younger than 75 years and treated for diabetes by their GP were eligible. Excluded were patients who, according to their GP, were too ill to follow the intervention program, and patients planning to go abroad for more than 6 months during the study period. A Turkish-speaking assistant, who was not aware to which group the patients were allocated, approached the patients to invite their 
participation. After informed consent and baseline measurements, patients were informed by letter whether they were allocated to the intervention or the control group.

\subsection{Intervention}

The two Turkish educators spoke fluent both Turkish and Dutch and were regarded as representatives of the target population. They were trained educators and had experience in educating in a primary care setting. They received an additional training about diabetes management and were supervised to translate advice on diabetes into understandable and (culturally) acceptable (ethnic-specific) advice for Turkish diabetes patients.

The planned 9-month program included: seven individual educational sessions and three group sessions. The individual sessions consisted of four sessions with the educator and patient together (if necessary one session together with a dietician), and three "triangle" sessions with GP, educator and patient present, to discuss the threemonthly assessment of the glycaemic control and cardiovascular risk factors.

Afterwards, the educator and patient discussed the triangle sessions. The group sessions were organised separately for men and women. The educators were allowed to adjust the number of the education sessions according to the needs of the individual patient. Individual and group sessions took place in the general practice.

Education was focused on attainment of self-care skills and behaviour change strategies, according to the ASE model (De Vries et al, 1998).

During the first individual session the educators were assigned to investigate the patient's attitude regarding diabetes-related behaviour (eating behaviour, exercise and medical compliance) according to the model, in order to prioritise the therapeutic goals. The second individual session was the first triangle session. For the third individual session an appointment was arranged together with a dietician and the patient's partner to discuss dietary rules. The fourth individual session focused on the patient's personal experiences and problems that hampered attainment of the goals. The fifth individual session was the second triangle session.

The first group session was mainly to discuss experiences and the patients received general information about diabetes. During the second group session the treatment of diabetes and self-care behaviour were discussed. Main topics in the third group session were prevention of diabetes-related complications and care of the feet. The sixth individual session, held after the three group sessions, was the third triangle session, followed by an evaluation of the group sessions focusing on the personal goals of the patient. During the seventh and final individual session (if possible together with the patient's partner) therapeutic goals were evaluated and the necessity of family support to reach and maintain the goals was discussed. 


\subsection{Outcome measures}

Plasma glucose, total cholesterol, HDL-cholesterol, and triglyceride were measured every three months with the 950 AT ORTHO diagnostics. Glycated haemoglobin was determined by the Variant-1 Biorad. LDL-cholesterol was calculated using the Friedewald formula (Friedewaid et al., 1972). All blood samples were taken in the fasting state using venous blood samples. The research assistants were instructed to measure systolic and diastolic blood pressure (Korotkoff V) on the left arm of the seated patient twice with a 2-minute interval using a mercurial blood pressure monitor and calculate the mean of the two measurements. Weight and height were measured to calculate the body mass index (BMI).

Since allocation to the intervention or control group was not random, differences in diabetes care between the two groups were considered as a potential confounder. In order to adjust for this confounder, features of diabetes care in the participating practices were assessed by analysing the medical records of all listed Turkish diabetes patients (including patients not in this study) in the participating practices, as described in a previous study (Uitewaal et al., 2003). Indicators of diabetes care were: 1) the mean number of recommendations from the Dutch GP guidelines on diabetes (Rutten et al., 1989) that were carried out (maximum 8), 2) the number of diabetes related-referrals of Turkish diabetes patients, and 3 ) the percentage of medication adjustments within three months after registration of increased plasma glucose levels (fasting $\geq 8.0 \mathrm{mmol} / \mathrm{l}$, non fasting $\geq 10.0 \mathrm{mmol} / \mathrm{l})$.

\subsection{Statistical analysis}

The main effect parameter was change in $\mathrm{HbA1c}$ between baseline measurement and one year follow-up. Power calculations were based on the assumption that the study should be able to detect a clinically relevant improvement in $\mathrm{HbA} 1 \mathrm{c}$ of $0.6 \%$ in the intervention group, based on an intention-to-treat analysis. With a $5 \%$ significance level and a power of $90 \%, 50$ patients were required in each group.

To adjust for potential confounding, multivariate linear regression analyses were carried out with change from baseline as outcome variable, and $\mathrm{HbA1c}$ at baseline, gender, age, years-since-diagnosis, mode of treatment, and the indicators of diabetes care as potential confounders. Because essential data were missing for some patients due to loss-to follow-up, we first carried out an intention-to-treat analysis, followed by an intention-to-treat analysis on the data set obtained by multiple imputation for missing data (Rubin and Schenker, 1991).

\section{Subgroup analyses}

To acquire additional information we decided in advance to perform subgroup analyses for patients with $\mathrm{HbA1c} \leq 7 \%$ (good glycaemic control) and $\mathrm{HbA} 1 \mathrm{c}>7$ at baseline, and for male and female patients separately. 


\subsection{Results}

Table 1 gives the baseline characteristics of the 104 patients included in the study: $38 \%$ were men, mean age was 52 (SD 6.0) years, mean number of years since diagnosis of diabetes was 6.0 (SD 4.6), and mean $\mathrm{HbA} 1 \mathrm{c}$ was $8 \%$ (SD1.6). There were no significant differences between the intervention and control group.

\begin{tabular}{|c|c|c|c|c|c|}
\hline $\begin{array}{l}\text { Age (years) } \\
\text { Men (number) } \\
\text { Number of years since diagnosis }\end{array}$ & $\begin{array}{c}\text { (n (I/C) } \\
53 / 51 \\
53 / 51 \\
53 / 51\end{array}$ & $\begin{array}{r}50,6 \\
21 \\
6.0\end{array}$ & $\begin{array}{l}(9.3) \\
(40) \\
(4.2)\end{array}$ & $\begin{array}{r}53.5 \\
19 \\
6.1\end{array}$ & $\begin{array}{r}(6.2) \\
(37) \\
(5.0)\end{array}$ \\
\hline $\begin{array}{l}\text { Body mass index (kg/m') } \\
\text { Smokers (number) }\end{array}$ & $\begin{array}{r}248 / 47 \\
-48 / 46\end{array}$ & $\begin{array}{r}32.8 \\
10\end{array}$ & $\begin{array}{l}(5.2) \\
(21)\end{array}$ & $\begin{array}{r}31.6 \\
9\end{array}$ & $\begin{array}{c}(4.5) \\
(20)\end{array}$ \\
\hline $\begin{array}{l}\text { Treatment for diabetes (number) } \\
\text { Diet } \\
\text { Sulphonylureas } \\
\text { Metformin } \\
\text { Combined oral hypoglycaemic agents } \\
\text { Insulin }\end{array}$ & $53 / 50$ & $\begin{array}{r}9 \\
23 \\
6 \\
13 \\
2\end{array}$ & $\begin{array}{l}(17) \\
43 \\
11 \\
(25) \\
(4)\end{array}$ & $\begin{array}{r}5 \\
21 \\
9 \\
15 \\
-\end{array}$ & $\begin{array}{l}(10) \\
(42) \\
(18) \\
(30) \\
(0)\end{array}$ \\
\hline $\begin{array}{l}\text { HbA1c }(\%) \\
\text { Fasting plasma glucose (mmol/l) } \\
\text { Total cholesterol (mmol//) } \\
\text { HDL-cholesterol (mmol/h) } \\
\text { LDL-cholesterol (mmol/h) } \\
\text { Triglyceride (mmol/ } /)\end{array}$ & $\begin{array}{r}50 / 49 \\
50 / 49 \\
50 / 49 \\
50 / 49 \\
249 / 43 \\
50 / 49\end{array}$ & $\begin{array}{r}8.2 \\
10.4 \\
5.3 \\
1.1 \\
3.1 \\
2.5\end{array}$ & $\begin{array}{l}(1.7) \\
(3.0) \\
(1.1) \\
0.4 \\
1.0 \\
(1.8)\end{array}$ & $\begin{array}{l}7.9 \\
9.8 \\
5.5 \\
1.0 \\
3.4 \\
2.7\end{array}$ & $\begin{array}{l}(1.6) \\
(3.3 \\
(1.0) \\
0.3 \\
0.9 \\
(1.5)\end{array}$ \\
\hline $\begin{array}{l}\text { Blood pressure }(\mathrm{mmHg}) \\
\text { Systolic } \\
\text { Diastolic }\end{array}$ & $\begin{array}{l}48 / 48 \\
448 / 48\end{array}$ & $\begin{array}{r}136 \\
88\end{array}$ & $\begin{array}{l}(17) \\
(10)\end{array}$ & $\begin{array}{r}141 \\
89\end{array}$ & (22) \\
\hline $\begin{array}{l}\text { Urinary albumin (number) } \\
>50 \\
>300\end{array}$ & $48 / 49$ & $\begin{array}{r}10 \\
5\end{array}$ & $\begin{array}{l}(21) \\
\text { (10) }\end{array}$ & $\begin{array}{l}8 \\
2\end{array}$ & $\begin{array}{c}(16) \\
(4)\end{array}$ \\
\hline
\end{tabular}

1) Baseline laboratory data were obtained from 50 patients in the intervention group and from 49 patients in the control group, and were missing in five patients ( 3 intervention, 2 control) that signed informed consent.

2) Missing data due to incomplete data set.

3) Due to high triglyceride level $(>4.5 \mathrm{mmo} / /)$ the LDL-cholesterol could not be calculated in 8 patients.

\section{Features of care for in the intervention and control practices (before the intervention)}

Analysis of the medical records of all listed diabetes patients yielded the following results. The mean number of guideline recommendations carried out (maximum 8 ) in the intervention practices was 2.0 (SD 2.0) per patient versus 2.7 (SD 1.7) per patient in the control practices. During the two-year registration before the intervention, $25 \%$ of the Turkish diabetes patients in the intervention practices were referred for diabetes treatment to hospital-based diabetes clinics versus $9.6 \%$ in the control practices. Within 
three months after measuring poor plasma glucose, medication was adjusted in $75 \%$ of the cases in the intervention practices versus $57 \%$ of the cases in the control practices.

\section{Loss to follow-up}

Of the 104 patients that signed informed consent, five patients $(3$ in the intervention and 2 in the control group) did not attend the laboratory for baseline measurements and dropped-out before the intervention. Another 14 patients (12 in the intervention and 2 in the control group) were lost to follow-up. Reasons for not completing the follow-up measurements were: refused (5), stayed abroad for a longer period (4), moved or changed physician (4), unable to be contacted (1).

\section{Glycaemic control}

Table 2 shows change in glycaemic control and cardiovascular risk factors after one year. There were no significant differences in the change in $\mathrm{HbA} 1 \mathrm{c}$ and fasting plasma between patients in the intervention and control group. Compared with the control group, mean $\mathrm{HbA} 1 \mathrm{C}$ in the intervention group decreased by $0.3 \%(95 \% \mathrm{Cl}:-0.8$ to 0.2$)$ and fasting plasma glucose decreased by $0.9 \mathrm{mmol} / 1(95 \% \mathrm{Cl}:-2.2$ to 0.3$)$. Adjustment for baseline value ( $\mathrm{HbA} 1 \mathrm{C})$, patient features (age, gender, years since diagnosis and use of medication) or practice features did not substantially alter these findings.

Table 3 gives the results of subgroup analyses for change in $\mathrm{HbA} 1 \mathrm{c}$ after one year for patients with baseline $\mathrm{HbA} 1 \mathrm{c} \leq 7 \%$ (good glycaemic control) and patients with baseline $\mathrm{HbA} 1 \mathrm{c}>7 \%$, for all patients, and for males and females separately. A significant effect of the intervention was seen only in women with increased plasma glucose levels (0.87\%; $95 \% \mathrm{Cl}-1.73$ to -0.09$)$.

\section{Cardiovascular risk factors}

No significant differences in the changes of plasma lipid levels, blood pressure and BMI in favour of the intervention group were observed at one-year follow-up.

The analyses based on the 104 patients that entered the study with missing values imputed by means of multiple imputation yielded similar results for the outcome measurements $\mathrm{HbA} 1 \mathrm{c}$ and cardiovascular risk factors.

\subsection{Discussion}

In this study targeting on first-generation Turkish immigrants with type 2 diabetes, bicultural education in general practice had no obvious beneficial effect on either glycaemic control parameters or cardiovascular risk factors. An improvement in $\mathrm{HbA} 1 \mathrm{c}$ of $0.6 \%$ in the intervention group, on which the power calculations were based, was not achieved; the study group was too small to detect an improvement smaller than $0.3 \%$. The expected larger improvement was based on the assumption that nearly all Turkish diabetes patients would have HbA1c levels $>7 \%$. However, this was not the case in $26(31 \%)$ of the 85 patients with completed data sets, which made an improvement of $0.6 \%$ more difficult to reach. 


\begin{tabular}{|c|c|c|c|c|c|c|c|c|}
\hline \multirow[b]{2}{*}{$\mathrm{HbA1}(\%)$} & \multirow{2}{*}{$\begin{array}{l}\begin{array}{c}\text { Inte } \\
\text { baseline }\end{array} \\
7.9(1.4)\end{array}$} & \multirow{2}{*}{$\begin{array}{r}\begin{array}{r}\text { vention gro } \\
\text { after one } \\
\text { year }\end{array} \\
7.6(1.2)\end{array}$} & \multirow{2}{*}{$\begin{array}{l}(n=38) \\
\text { changa from } \\
\text { baseline } \\
-0.3(1.3)\end{array}$} & \multirow{2}{*}{$\begin{array}{l}\text { baseline } \\
8.0(1.6)\end{array}$} & \multicolumn{2}{|c|}{$\begin{array}{c}\text { Control growp ( } n=47) \\
\text { afier one change from } \\
\text { year baseline }\end{array}$} & \multicolumn{2}{|c|}{$\begin{array}{l}\text { Difference between changes } \\
\text { from baseline in intervention } \\
\text { and control group ( } 95 \% \mathrm{Cl})\end{array}$} \\
\hline & & & & & $8.0(1.5)$ & $0.03(0.9)$ & .0 .3 & $(-0.8$ to 0.2$)$ \\
\hline Fasting plasma glucose (mmol/ $)$ & $10.1(3.0)$ & $8.8(2.9)$ & $-1.3(3.2)$ & $9.9(3.3)$ & $9.7(2.8)$ & $-0.4(2.5)$ & .0 .9 & $(-2.2$ to 0.3$)$ \\
\hline Total cholesterol (mmolin) & $5.1(1.0)$ & $5.0(1.0)$ & $-0.1(0.7)$ & $5.5(1.0)$ & $5.5(1.0)$ & $-0.1(0.6)$ & -0.1 & $(-0.4$ to 0.2$)$ \\
\hline HDL-Cholesterol (mmall) & $1.2(0.3)$ & $1.1(0.3)$ & $-0.1(0.2)$ & $1.0(0,3)$ & $1.1(0.3)$ & $0.1(0.1)$ & 0.1 & $(0.05$ to 0.2$)$ \\
\hline LDL-Cholesterol (mmol/i) & $3.0(0.9)$ & $3.0(0.9)$ & $-0.1(0.8)$ & $3.4(0.9)$ & $3.3(0.9)$ & $-0.2(0.7)$ & 0.1 & $(-0.2$ to 0.5$)$ \\
\hline Triglyceride (mmol/l) & $2.3(1.9)$ & $2.0(1.1)$ & $-0.3(1.3)$ & $2.7(1.6)$ & $2.5(1.9)$ & $-0.2(1.2)$ & 0.17 & $(-7$ to 0.4$)$ \\
\hline Body mass index $(\mathrm{kg} / \mathrm{m})$ & $33.0<57$ & $32.3(4.9)$ & $-0.2(1.7)$ & $31.7(4.5)$ & $30.9(4.4)$ & $-0.5(1.1)$ & 0.3 & $(-0.3$ ta 1.0$)$ \\
\hline \multicolumn{9}{|l|}{ Blood pressure $(\mathrm{mm} \mathrm{Hg})$} \\
\hline Systolic & $136(19)$ & 131 (16) & $-5(13)$ & $141(22)$ & $142(25)$ & $1(22)$ & 6 & $(-15$ to 2$)$ \\
\hline Diastolic & $88(11)$ & $85(11)$ & $-4(8)$ & $89(10)$ & $87(12)$ & $2(12)$ & 1 & $(-6$ to 4$)$ \\
\hline
\end{tabular}

1) 14 patients ( 12 in the intervention and 2 in the control group) with completed baseline measurements were lost to follow-up. Reasons for lost top follow-up were: refused (5), stayed abroad for a longer period (4), four moved or changed physician (4), unable to be contacted (1).

2) Adjusted for HbA1c at baseline and patient characteristics (age, gender, years since diagnosis, mode of treatment: tjiet alone or use of oral hypoglycaemic agents 
The finding that the intervention was slightly more effective in women warrants some discussion. Firstly, the lower HbA1c level at baseline in the male patients in the intervention group with completed data sets ( $\mathrm{HbA} 1 \mathrm{c}$ of $7.7 \%$ in the male intervention versus $8.0 \%$ in the male control group), and the small number of men might explain why no decrease in $\mathrm{HbA1c}$ in men could be shown, whereas men in the intervention group had a HbA1c level similar to the women at one-year follow-up $(7.6 \%$ in both men and women). Secondly, the influence of gender inequality between the female educator and the male patients might explain the lack of effect in men. A recent study showed the positive influence of gender equality on the effectiveness of health education (Voorham and Kocken, 2000). In our study, both of the Turkish educators were female and (for cultural reasons) Turkish male patients may feel less inclined to take advice regarding behavioural changes from women. Indeed, another report of this study showed that the Turkish females experienced more change in behaviour than the Turkish men (Voorham et al, 2002). Attention to gender equality should be considered in future studies.

Thirdly, the contents of the message should possibly be more gender specific.

\begin{tabular}{|c|c|c|c|c|c|}
\hline \multirow[t]{2}{*}{$\begin{array}{l}\text { Patient } \\
\text { group }\end{array}$} & \multirow[t]{2}{*}{$\mathrm{n}$} & \multirow{2}{*}{ 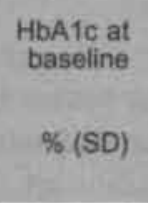 } & \multirow{2}{*}{$\begin{array}{l}\text { HbAlc at } \\
\text { one year } \\
\%(S D)\end{array}$} & \multicolumn{2}{|c|}{$\begin{array}{l}\text { Difference between } \\
\text { intervention and } \\
\text { control }\end{array}$} \\
\hline & & & & B & $\begin{array}{l}95 \% \text { Confidence } \\
\text { interval }\end{array}$ \\
\hline $\begin{array}{l}\text { All patients } \\
\text { Intervention } \\
\text { Control }\end{array}$ & $\begin{array}{l}38 \\
47\end{array}$ & $\begin{array}{l}7.9(1.4) \\
8.0(1.6)\end{array}$ & $\begin{array}{l}7.6(1.2) \\
8.0(1.4)\end{array}$ & -0.30 & $(-0.74$ to 0.14$)$ \\
\hline $\begin{array}{l}\text { Male patients } \\
\text { Intervention } \\
\text { Control }\end{array}$ & $\begin{array}{l}14 \\
19\end{array}$ & $\begin{array}{l}7.7(1.3) \\
8.0(1.7)\end{array}$ & $\begin{array}{l}7.6(1.3) \\
7.9(1.3)\end{array}$ & -0.09 & $(-0.75$ to 0.57$)$ \\
\hline $\begin{array}{l}\text { Female patients } \\
\text { Intervention } \\
\text { Control }\end{array}$ & $\begin{array}{l}24 \\
28\end{array}$ & $\begin{array}{l}8.0(1.5) \\
8.0(1.5)\end{array}$ & $\begin{array}{l}7.6(1.1) \\
8.0(1.6)\end{array}$ & -0.49 & $(-1.11$ to 0.13$)$ \\
\hline $\begin{array}{l}\text { Patients with HbA1c } \leq 7 \% \\
\text { Intervention } \\
\text { Control }\end{array}$ & $\begin{array}{l}10 \\
16\end{array}$ & $\begin{array}{l}6.5(0.5) \\
6.7(0.3)\end{array}$ & $\begin{array}{l}6.9(0.9) \\
7.0(0.8)\end{array}$ & 0.25 & $(-0.34$ to 0.84$)$ \\
\hline $\begin{array}{l}\text { Patients with HbA te >7\% } \\
\text { Intervention } \\
\text { Control }\end{array}$ & $\begin{array}{l}28 \\
31\end{array}$ & $\begin{array}{l}8.4(1.3) \\
8.6(1.5)\end{array}$ & $\begin{array}{l}7.9(1.2) \\
8.5(1.5)\end{array}$ & -0.53 & $(-1.09$ to 0.04$)$ \\
\hline $\begin{array}{l}\text { Male patients with } \mathrm{HbA} \text { ic }>7 \% \\
\text { Intervention } \\
\text { Control }\end{array}$ & $\begin{array}{l}10 \\
14\end{array}$ & $\begin{array}{l}8.2(1.0) \\
8.6(1.8)\end{array}$ & $\begin{array}{l}7.8(1.3) \\
8.2(1.5)\end{array}$ & 0.06 & $(-0.78$ to 0.90$)$ \\
\hline $\begin{array}{l}\text { Female patients with } \mathrm{HbA1c}>7 \% \\
\text { Intervention } \\
\text { Control }\end{array}$ & $\begin{array}{l}18 \\
17\end{array}$ & $\begin{array}{l}8.6(1.4) \\
8.7(1.4)\end{array}$ & $\begin{array}{l}7.9(1.1) \\
8.7(1.5)\end{array}$ & -0.87 & $(-1.73$ to -0.09$)$ \\
\hline
\end{tabular}

1) Adjusted for $\mathrm{HbA1c}$ at baseline and patient characteristics (age, gender, years since diagnosis, mode of treatment: diet alone or use of oral hypoglycaemic agents) 
Although no studies were performed to prove this, it seems well possible that the susceptibility for behavioural advice differs between Turkish men and women.

The first methodological limitation of this study was the absence of randomisation, which was not possible for three reasons. First, the bicultural educators were already working in the participating intervention practices and Turkish patients were familiar with the facility; exclusion of diabetes patients from this facility for a longer period was not considered an option. Secondly, the number of patients per general practice would be too small to arrange group education within each general practice. Thirdly, the danger of contamination between patients of the control and intervention group was considered too large, particularly because older Turkish patients living in one district form close networks.

A second limitation concerns the drop-out. Because we were unable to follow-up 15 of the $\mathbf{5 3}$ patients that dropped-out the intervention, it was impossible to perform a traditional intention-to-treat analysis. Reasons for dropping-out were diverse and many patients dropped-out before or early on in the intervention, and only 5 patients droppedout for education-related reasons. Thus, the possibility of bias induced by selective drop-out is very limited. Importantly, this is illustrated by analysis of the data set obtained by multiple imputation for missing data, which yielded similar results on both $\mathrm{HbA1C}$ and cardiovascular risk factors.

To our knowledge this is the first study to assess the effect of ethnic-specific diabetes education on glycaemic control in Turkish diabetes patients. Although the results show that our educational approach has no clearly effect on glycaemic control or cardiovascular risk factors, our finding of a larger effect in women warrants further study. 


\section{References}

Carter J.S., Pugh J.A., Monterrosa M.D. Non-insulin-dependent diabetes mellitus in minorities in the United States. Ann. Intern. Med. 1996: 125: 221-32.

Cowie C.C., Harris M.I., Silverman R.E., Johnson E.W., Rust K.F. Effect of multiple risk factors on differences between blacks and whites in prevalence of non-insulin-dependent diabetes mellitus in the United States. Am. J. Epidemiol. 1993; 137: 719-32.

Elasy T.A., Ellis S.E., Brown A., Pichert J.W. A taxonomy for diabetes educational interventions. Patient. Educ. Couns. 2001; 43: 121- 7.

Friedewald W.T., Levy R.I., Fredrickson D.S. Estimation of the distribution of low-density lipoprotein cholesterol in plasma without the use of the preparative ultracentrifuge. Clin. Chem. 1972; 18: 499-502.

Hawthorne K., Tomlinson S. Pakistani Moslems with type 2 diabetes mellitus: effect of sex, literacy skills, known diabetic complications and place of care on diabetic knowledge, reported self-monitoring management and glycaemic control. Diab. Med. 1999; 16: 591-7.

Marshall J.A., Hamman R.F., Baxter J., Mayer E.J., Fulton D.L., Orleans M., Rewers M., Jones R.H. Ethnic differences in risk factors associated with the prevalence of non-insulindependent diabetes mellitus. Am. J. Epidemiol. 1993; 137: 706-18.

Rubin D.B., Schenker N. Multiple imputation in health care database: an overview and some applications. Stat. Med. 1991; 10:585-98.

Rutten G.E.H.M., Cromme P.V.M., Zuidweg J., Mulder J.D. General practitioner and type 2 diabetes: a justification of the Dutch standard [In Dutch: Huisarts en diabetes type 2: een verantwoording voor de NHG standaard.] Huisarts \& Wetenschap 1989; 32: 7-13.

Uitewaal P.J.M., Bruijnzeels M., Bernsen R., Voorham A.J.J., Thomas S. Diabetes care in Dutch general practice: differences between Turkish immigrants and Dutch patients.

Eur. J. Public Health 2003, in press.

Voorham A.J.J., Kocken P.L. Kenmerken van de voorlichter bij het effect van seniorenvoorlichting (Characteristics of peer health educator and the effect of peer-led senior health education). Tijdschr. Soc. Gezondheidsz. 2000; 78: 303-8.

Voorham A.J.J., Uitewaal P.J.M., Bruijnzeels M. Het effect van voorlichting in de eigen taal aan Turkse diabetespatiënten (Effects of a peer-led health education program aimed at Turkish diabetes patients). Tijdschr. Soc. Gezondheidsz. 2002; 80: 514-520.

Vries H. de, Dijkstra M., Kuhlman P. Self-efficacy: the third factor besides attitude and subjective norm as a predictor of behavioural intentions. Health. Educ. Res. 1988; $3: 273-82$.

Weijers R.N.M., Bekedam D.J., Oosting H. The prevalence of type 2 diabetes and gestational diabetes mellitus in an inner city multi-ethnic population. Eur. J. Epidemiol. 1998; 14:

693-99. 


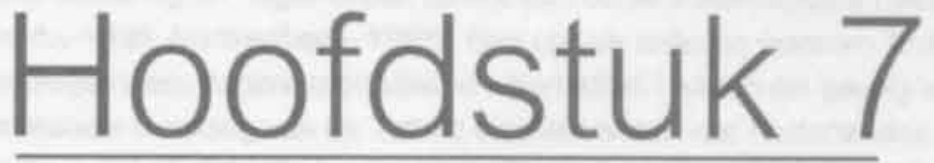

Het effect van voorlichting

in de eigen taal aan Turkse

diabetespatiënten.

Een experiment in de eerste lijn 


\section{Summary}

Effects of a peer-led health education program aimed at Turkish diabetes patients In general practice a peer-led health education programme for Turkish patients with diabetes mellitus II (Non Insulin Dependent Diabetes Mellitus, NIDDM) was carried out. The health education was tailored to the needs of the individual patient, and consisted of triangle consultations with the general practitioner, the patient and the health educator, of individual consultations with the patient, and of group sessions with other diabetes patients. A control group was formed by selecting general practitioners with the same diabetic control regime. The control patients received regular care. The patients were interviewed at home before and after de intervention about diabetes related behaviour on eating, physical exercise and compliance in relation to medication. Effects were shown on the quality of the communication, on some of the determinants of the advised behaviour. And an effect of the intervention was shown on eating behaviour and on physical exercise. Subjective changes in care and behaviour were larger in the intervention group then in the control group. And there was a decrease in the number and seriousness of diabetes related complaints in the subgroup of the women and the respondents younger then fifty years of age. This pattern was also found in other outcome measures (Voorham, Uitewaal and de Hoop, 2001). Maybe our relative young female peer educator with her behaviour-related counselling had more connection with her female patients then with the male patients. Concluded is that peer led migrant health education can be an adequate supplement in general practice for a better diabetes care for Turkish patients, and that the peer education to reach the men need more attention. 


\section{Het effect van voorlichting in de eigen taal aan Turkse diabetespatiënten}

\subsection{Inleiding}

Turken vormen in Rotterdamse achterstandswijken een zeer omvangrijke groep en behoren tot de groepen met de laagste sociaal-economische status. De prevalentie van diabetes mellitus type II (DM II) is hoger onder lagere sociale lagen van de Nederlandse bevolking en hoger onder Turken dan onder Nederlanders (Sweep et al, 1994; Querido, 1995; Mackenbach, 1996). Een van de redenen waarom Turken uit achterstandswijken een hogere mortaliteit en morbiditeit hebben als gevolg van DM II is dat de metabole instelling van de Turken slechter is dan van Nederlandse diabeten. Waarschijnlijk is dat zij zich minder goed aan de adviezen van de huisarts (kunnen) houden. Bovendien zal een aantal adviezen betreffende dieet, lichaamsbeweging en medicatie niet altijd aansluiten bij de Turkse cultuur.

Om een doelmatige huisartsenzorg aan allochtonen in Rotterdam te bevorderen, is gestart met migrantenvoorlichting in de eerste lijn. De kern van deze interventie is een zelfstandig spreekuur van de migrantenvoorlichtsters in de huisartspraktijk. Verder is het voor de huisarts mogelijk de voorlichtsters in te schakelen bij communicatieproblemen tijdens het spreekuur in een driegesprek (Bruijnzeels e.a., 1999). De voorlichting over diabetes bij Turken is gericht op de verbetering van de metabole instelling van Turken met diabetes mellitus type II door individuele begeleiding in de eigen taal. Het project is opgezet als een gecontroleerd experiment, en is als subsidieproject gehonoreerd door de Commissie Sociaal -Economische Gezondheidsverschillen van het Ministerie voor Volksgezondheid, Wetenschap en Sport (Sturmans en Voorham, 1996).

\subsection{Omschrijving van de interventie}

In 1992 heeft Brown een meta-analyse uitgevoerd op diabetes educatie projecten (Brown, 1992). Zij concludeert dat over alle studies de effecten op metabole waarden dramatisch kleiner zijn onder patiënten ouder dan 55 jaar. Er blijkt geen duidelijke relatie met de setting: vanuit het ziekenhuis of buiten het ziekenhuis. Ze concludeert dat het effect in de eerste zes maanden van de interventie wordt bereikt. Daarna treedt er een daling van de effectiviteit op, vermoedelijk door gebrek aan gedragsbehoud. Ze concludeert dat de grootste kans op effect een planmatige, individuele benadering biedt, vanwege de mogelijkheid van advisering op maat. Er waren op dat moment geen studies beschikbaar die rekening hielden met etniciteit. In Nederland rapporteren Ahrend en Schrijvers over een effectief educatieprogramma van zes groepsbijeenkomsten, ingebed in de zorgverlening. De nuchtere glucosewaarde als uitkomstmaat is echter discutabel (Ahrend en Schrijvers, 1996). Daniel e.a. (1999) rapporteren over een community diabetes programma onder 'aboriginals' in Canada. De resultaten van dat 16-maanden durend programma zijn zeer teleurstellend. Ze wijten dat gebrek aan 
effect aan de overheersende top-down benadering, en het gebrek aan inbreng van de community. Agurs-Collins e.a. (1997) beschrijven de effecten van een gecontroleerd experiment met het stimuleren van gewichtsreductie en lichaamsbeweging bij AfroAmerikanen. Het betreft een uitgebreid programma met langdurige intensieve groepsbegeleiding, met cultureel aangepaste materialen en veel Afro-Amerikaanse community betrokkenheid en community activiteiten. De resultaten zijn zeer positief. Uit de gebrekkige beschrijving van de interventie wordt niet duidelijk of er ook 'peer' voorlichters zijn gebruikt. Murphy e.a. (1993) verdedigen de inzet van peers, niet alleen als voorlichters maar vooral als culturele vertalers. Khanchandani en Gillam (1999) schrijven over het werk en het belang van een 'ethnic minority link worker' in de huisartspraktijk. Ze verdedigen de inzet van de link worker voor diabetes en voor astma. Corkery e.a. (1997) rapporteren over de inzet van een 'bicultural community health worker'. Die inzet blijkt effectief vooral met betrekking tot uitval: de controlegroep maakt het normale nonexperimentele educatieprogramma veel vaker niet af, en de interventiegroep heeft, mogelijk daardoor, een betere metabole instelling na de interventie. Het effect van de inzet van de 'community health worker' kon niet significant worden aangetoond bij de patiënten die hun programma voltooiden (Corkery e.a., 1997).

De interventie in dit onderzoek bestaat uit een begeleidingstraject van ongeveer negen maanden voor diabetes mellitus type II patiënten van Turkse afkomst, waarbij een migrantenvoorlichtster als brug tussen hulpverleners en de diabetespatiënt functioneert om cultuur - en communicatieverschillen te overwinnen. Tevens verzorgt de voorlichtster op individuele basis voorlichting over DM II, waarbij speciaal aandacht besteed wordt aan therapie, acceptatie van en omgaan met de ziekte en de rol van de omgeving daarbij. Het Health Counseling Model van Gerards wordt gebruikt als basis voor de voorlichting (Gerards, 1993). Het is de bedoeling dat de patiënten drie individuele gesprekken, drie driegesprekken met de huisarts en één of meerdere bijeenkomsten met de diëtist krijgen. In het interventieprogramma zijn bovendien drie groepsvoorlichtingen opgenomen voor lotgenotencontact (de Hoop, 1997). Het einddoel van de interventie is het bewerkstelligen van een verbeterde bloedsuikerspiegel bij Turkse diabetes type II patiënten. De bloedsuikerspiegel van een diabetespatiënt kan goed worden ingesteld als de patiënt zich houdt aan een aantal adviezen met betrekking tot voeding. beweging en medicijngebruik. Om deze einddoelen te bereiken wordt, vooral middels de driegesprekken, nagestreefd om de communicatie tussen de patiënt en de huisarts te verbeteren. Gestimuleerd wordt dat er,één of meer bezoeken aan de diëtiste worden gebracht. En de voorlichtster stimuleert de patiënt om zich te houden aan de gedragsadviezen. Voor de meeste patiënten wil dat zeggen: minder vet eten, in totaal minder eten, regelmatiger eten, méér bewegen en de medicijnen trouw innemen. Het resultaat van een beter ingestelde bloedsuikerspiegel zal zijn dat de patiënt ook minder diabetesgebonden klachten zal hebben. Het werk van de voorlichtster kan dus in twee delen worden gezien. In de eerste plaats vormt ze een brug tussen de zorg en de patiënt. Ze stimuleert en vergemakkelijkt de communicatie tussen de hulpverleners en de patiënt. En op de tweede plaats is een belangrijk kenmerk van de interventie de advisering op maat. De voorlichtster probeert te achterhalen in welke fase van gedragsverandering de 
patiënt is, en stemt haar advies daarop af. De voorlichtster licht de patiēnt voor, legt de complexe problematiek rond diabetes uit, en maakt gebruik van de kansen die ze ziet om de patiënt tot gezonder gedrag te motiveren. Het uitgangspunt is dat de voorlichtster altijd toekomt aan het verbeteren van de communicatie en het motiveren tot het opvolgen van de gedragsadviezen.

In dit artikel wordt het evaluatieonderzoek gerapporteerd naar het effect van deze migrantenvoorlichting op de kwaliteit van de zorg: de kwaliteit van de communicatie met de huisarts en de bezoeken aan de diëtiste, gedragsdoelen (voedingsgedrag en beweeggedrag), en de determinanten van dat gedrag.

de ervaren veranderingen bij de patiënt met betrekking tot deze gedragsdoelen, en de diabetesgebonden klachten. In een andere rapportage is het effect van de interventie beschreven op de bloedsuikerwaarden ( $\mathrm{HbA1c}$ ) en enkele andere biomedische indicatoren (Voorham e.a. 2001).

\subsection{Onderzoekspopulatie}

De onderzoekspopulatie bestaat uit Turkse DM II patiënten jonger dan 75 jaar, die voor hun diabetes behandeld worden door hun huisarts. Turks wordt gedefinieerd volgens het criterium van het Ministerie van Binnenlandse zaken. lemand heeft een Turkse etnische achtergrond als hij/zij zelf in Turkije is geboren en/of tenminste een van beide ouders is in Turkije geboren. De deelnemers aan de interventie zijn geselecteerd uit drie gezondheidscentra en vier praktijken van solistisch werkende huisartsen in Rotterdam Zuid. Door de huisartsen zijn de patiënten geselecteerd die bij hen bekend waren als diabetespatiënt. De controlepraktijken werden geselecteerd uit gelijke achterstandsbuurten, en bij de betrokken huisartsen werdnagegaan of de reguliere diabeteszorg overeenkwam met de praktijken die aan de interventie meededen. Er werd geen verschil aangetroffen met betrekking tot de uit de standaard van het Nederlands Huisartsen Genootschap afleidbare kwantificeerbare indicatoren (Uitewaal e.a.,aangeboden). Voor deze procedure is gekozen omdat in een situatie van at random toewijzing van patiënten aan de experimentele condities het gevaar van contaminatie té groot is. Zo is het bijvoorbeeld niet mogelijk om groepsvoorlichting te organiseren in een gezondheidscentrum waarbij een gedeelte van de diabetespatiënten over zo'n relatief lange periode is uitgesloten van deelname aan die groepen. Patiënten die gedurende het onderzoek een lange periode in het buitenland verbleven zijn uitgesloten van het onderzoek. Er is dan onvoldoende zicht op de ontwikkeling van de bloedsuikerwaarden en er is te weinig tijd over voor een goede interventie. De selectie vond plaats op basis van de gegevensbestanden van de huisartsen. De werving vond plaats middels een brief aan alle door de huisartsen geselecteerde patiënten. Na de brief werden de patiënten benaderd door een Turks sprekende werfster. Na het geven van een 'informed consent' werden de namen doorgegeven aan het onderzoeksbureau dat de interviews verzorgde.

Van de 108 patiënten die aan het begin van het project een 'informed consent' hebben gegeven, hebben uiteindelijk 75 patiênten aan de nameting meegewerkt. In de experi- 
mentele praktijken hebben 56 patiënten ingestemd, en daarvan zijn uiteindelijk 34 in de onderzoeksgroep terecht gekomen. In de controle praktijken hebben 52 patiënten ingestemd, en zijn er uiteindelijk 41 in de onderzoeksgroep opgenomen. Er is dus méér uitval uit de experimentele groep dan uit de controle groep. Dat kan een ernstige belemmering zijn voor de validiteit van het onderzoek als de interventie een reden voor die uitval is geweest. Uit de redenen voor uitval kan niet worden afgeleid dat de interventie een bijdrage aan die uitval heeft geleverd. Er zijn in de interventiegroep méér verwijzingen naar de specialist geweest en er is vaker van huisarts veranderd. Ook valt op dat zowel voor de controlegroep (vier maal) als de interventie groep (ook vier maal) langdurig verblijf in Turkije een belangrijke belemmering is geweest voor het realiseren van de nameting. Voor het grootste deel, even vaak in de experimentele als in de controle groep, is de reden van de uitval onbekend door het ontbreken van een nameting.

\subsection{Methode}

Omdat de interventie op verschillende punten in de fase van gedragsverandering van de patiënt kan aangrijpen, is het voor het verwerven van inzicht in de effectiviteit van belang dat de uitkomstmaten ook breed worden gekozen. In deze evaluatie is aandacht voor de communicatie met de zorgverleners, voor het geadviseerde gedrag, én voor de determinanten van dat gedrag volgens het model van Ajzen (1991), voor de diabetes gebonden klachten (Grootenhuis e.a.,1994), en voor de ervaren veranderingen bij de patiënt. Een uitgebreide beschrijving van de operationalisatie van de onderstaande variabelen is bij de auteurs op te vragen. Als uitkomstmaten in deze evaluatie worden gebruikt:

- De communicatie met de huisarts (twee items, $\alpha=0,85$, en een bereik van 1-10),

- Het aantal bezoeken aan de diëtiste,

- De algemene kennis over DM -2, 11 stellingen over voeding, lichaamsbeweging en medicijngebruik (bereik 0-11),

- De attitude ten opzichte van de adviesonderwerpen, (zeven items, bereik 5-35, $\alpha=0,70$ ),

- De persoonlijke effectiviteit met betrekking tot het voedingsadvies (twee items, bereik 2-10, $\alpha=0,79$ ), met betrekking tot het omgaan met diabetes (drie items, bereik 3-15, $\alpha=0,63$ ), met betrekking tot concrete voedingsadviezen (vier items, $4-20, \alpha=0,63$ ), met betrekking tot meer bewegen (enkel item, 1-5),

- De sociale norm met betrekking tot de adviesgedragingen, (tien items, bereik 10-50, $\alpha=0,93$ )

- De intentie tot het geadviseerde gedrag. (tien items, bereik 10-50, $\alpha=0,81$ ).

- Gedrag met betrekking tot de dieetvoorschriften, (drie items, bereik 3-15, $\alpha=0,93$ ),

- Concreet gedrag betreffende de inname van de hoeveelheid en kwaliteit van kaas (foto's van feta) (bereik 1-5).

- Het aantal eetmomenten op een dag (bereik 1-7),

- Medicatietrouw, subjectief, een enkel item (bereik 0-9),

- Lichamelijke inspanning bij dagelijkse bezigheden zoals boodschappen doen, op 
visite of naar de moskee gaan: het aantal minuten én het aantal malen langer dan 30 minuten,

- Ervaren veranderingen met betrekking tot de kennis die men heeft (drie items, bereik $3-12, \alpha=0,96$ ), met betrekking het voedingsgedrag (drie items, bereik $3-12, \alpha=0,87$ ). met betrekking de aandacht van de directe sociale omgeving (vier items, bereik 4-16, $\alpha=0,97$ ), met betrekking tot het medicijngebruik (twee items, bereik $2-8, \alpha=0,85$ ), met betrekking de lichamelijke activiteiten (drie items, bereik $3-12, \alpha=0,66$ ), met betrekking de zorg (vijf items, bereik 5-20, $\alpha=0,88$ ).

- De diabetes gerelateerde klachten: de DSC type 2: 32 vragen (bereik 32-160, $\alpha=0,95$ ).

De vragenlijst is vertaald in het Turks, en de vertaling is gecontroleerd door twee Turkse medewerkers. Daarna is de vragenlijst een aantal malen uitgetest. De vragenlijst is mondeling bij de respondenten thuis afgenomen. Het interview duurde een uur tot anderhalf uur. Voor de interviews is een commercieel dataverzamelingsbureau ingeschakeld dat relatief veel ervaring had met migranten als doelgroep.

\subsection{Analyse}

De respons voor de experimentele en controle groep is vastgesteld, en er is onderzocht of de controle groep en de experimentele groep van elkaar verschilt met betrekking tot relevante achtergrondkenmerken, zoals sekse, leeftijd en aantal jaren diabetespatiënt. Het effect van de interventie is geanalyseerd met behulp van GLM van SPSS-10 voor Windows (Unianova), met de score bij de nameting als afhankelijke variabele, groep (experimenteel of controle) en sekse als determinanten, met leeftijd en de score op de voormeting als covariaten. Er is steeds onderzocht of er interactie is met leeftijd en met sekse. Waar dat het geval is (de $p$ van de interactieterm kleiner is dan 0,10 ) worden die de resultaten weergegeven. Gerapporteerd wordt het gemiddelde verschil, gebaseerd op de geschatte marginale gemiddelden, en het betrouwbaarheidsinterval van dat verschil.

\subsection{Resultaten}

In tabel 1 staan de achtergrondkenmerken van de controle groep en de experimentele groep vermeld. Alleen met betrekking tot de leeftijd is er een verschil zichtbaar tussen de controle groep en de experimentele groep, namelijk de controle groep is iets ouder dan de experimentele groep. In de analyse is rekening gehouden met het leeftijdsverschil door de leeftijd steeds als covariaat in de varantie-analyse te betrekken. Er zijn voor de effectevaluatie minder vragen bruikbaar gebleken dan was gehoopt. De belangrijkste reden is een hoge non-respons op specifieke vragen in de nameting. Daar wreekt zich het feit dat standaard vragenlijsten nog nauwelijks gevalideerd zijn voor de Turkse doelgroep. En in dit evaluatieonderzoek kon slechts geringe aandacht zijn voor het valideren van de vragenilist. 


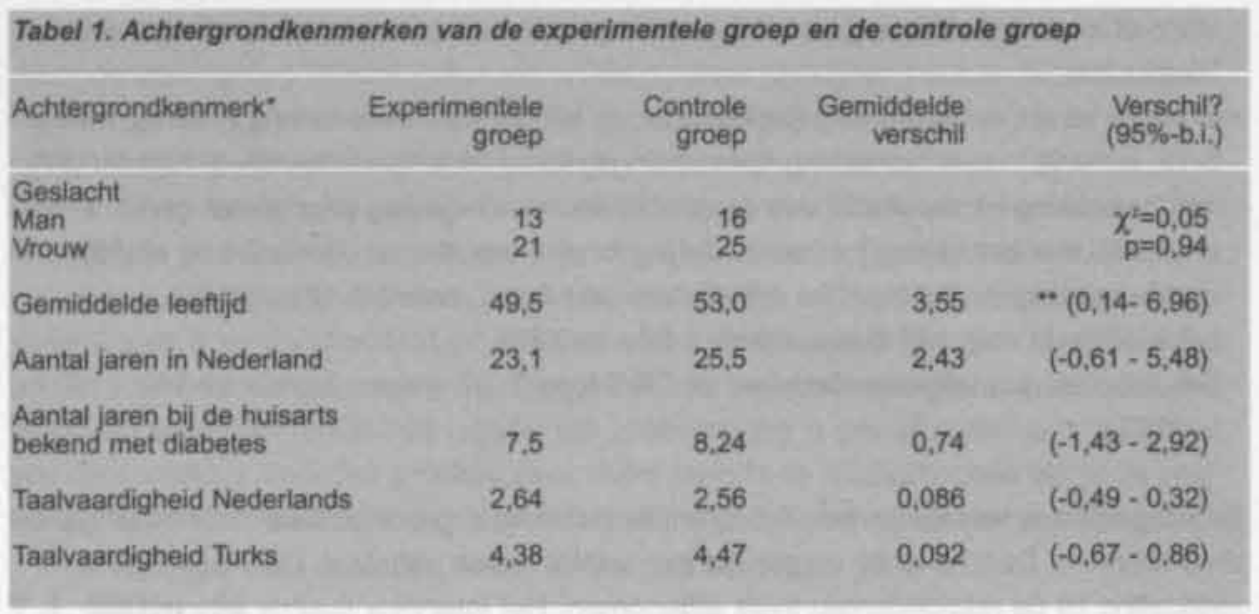

- Slechts 4 mensen zijn ongehuwd/weduwnaar of gescheiden, gelijk verdeeld over experimentele en controle groep.

* De interventiegroep is gemiddeld 3,5 jonger dan de controlegroep.

Vanaf tabel 2 staan de gemiddelde verschilscores van de belangrijkste uitkomstvariabelen vermeld. De subjectieve indruk van de kwaliteit van de communicatie is voor de totale groep slechts gering verbeterd. Wel blijkt er een interactie met sekse: de vrouwen ervaren de communicatie met de huisarts na de interventie positiever (verschil: $-1,85$; betrouwbaarheidsinterval: $-3,49--0,20$ ), en de mannen juist negatiever (verschil: 1,31: betrouwbaarheidsinterval: $-0,62--3,25)$. De vrouwelijke respondenten hebben na de interventie vaker dan de mannen het idee bij de huisarts alles te hebben gevraagd en te hebben begrepen. De volgende uitkomstmaat in tabel 2 betreft het aantal bezoeken aan de diêtiste. De interventiegroep is in de experimentele periode vaker naar de diëtiste geweest dan de controlegroep. De voorlichtster heeft daarin dus een bemiddelende en stimulerende rol kunnen hebben.

In de kennis over DM -2 (niet in een tabel opgenomen) is noch bij de interventiegroep noch bij de controlegroep iets veranderd. Dat geldt ook voor de algemene kennis over de adviesonderwerpen (voeding, bewegen en medicijngebruik). De attitude met betrekking tot de adviesonderwerpen is wel verbeterd: de interventiegroep heeft in de nameting een positievere houding ten opzichte van het voedingsadvies en het advies met betrekking tot lichaamsbeweging (verschil: $-2,61$; betrouwbaarheidsinterval: $-4,71--0,51)$. Er is geen effect aangetoond op de persoonlijke effectiviteit van de patiënten met betrekking tot het geadviseerde gedrag. En datzelfde geldt voor de sociale norm en de intentie met betrekking tot het geadviseerde gedrag.

Bij het aantal eetmomenten (zie tabel 2), dat is het advies voor diabetespatiënten om vaker met kleinere porties te eten, is een verbetering zichtbaar, maar die is er bij de controle groep eveneens, dus het gemiddelde verschil is klein. Bij de subjectieve beoordeling van de patiēnt of men zich houdt aan het dieetadvies, is er wel een verbetering zichtbaar in de verwachte richting. Dat is echter ook in de controle groep het geval. Vragend naar een concreet voedingsgedrag, in dit geval de hoeveelheid en de 


\begin{tabular}{|c|c|c|c|c|}
\hline Uitkomstvariabelen & Bereik & $(\mathrm{E} / \mathrm{C})$ & E-C & $(95 \%-$ B.L. $)$ \\
\hline $\begin{array}{l}\text { Communicatie met de huisarts } \\
\text { (laag =gewenst) }\end{array}$ & $(1-10)$ & $(34 / 41)$ & -0.27 & $(-1,50-0,96)$ \\
\hline Aantal bezoeken aan diêtiste & $(1-3)$ & $(34 / 41)$ & 0,64 & $\cdot(0,10-1,17)$ \\
\hline $\begin{array}{l}\text { Gerapporteerd gedrag: } \\
\text { Aantal eetmomenten per dag } \\
\text { Houden aan dieet: laag gewenst } \\
\text { Concreet voedingsgedrag (kaas) } \\
\text { Medicatietrouw, subjectief } \\
\text { Bewegen: aantal minuten/week } \\
\text { Aantal maal > } 30 \text { minuten/week }\end{array}$ & $\begin{array}{r}(1-7) \\
(3-15) \\
(1-5) \\
0-9)\end{array}$ & $\begin{array}{l}(31 / 23) \\
(32 / 37) \\
(28 / 36) \\
(23 / 32) \\
(28 / 29) \\
(34 / 41)\end{array}$ & $\begin{array}{r}0.46 \\
0.29 \\
-0.55 \\
-0.16 \\
95,0 \\
0.51\end{array}$ & $\begin{array}{l}\left\{\begin{array}{l}-0,33-1,26) \\
-1,32-1,91 \\
-1,05-0,04 \\
-1,13-0,81 \\
14,5-172,7 \\
0.12-0,92\end{array}\right) \\
+\left(\begin{array}{c}0,12 \\
0\end{array}\right)\end{array}$ \\
\hline Ervaren veranderingen & $(20-80)$ & $(32 / 39)$ & $-10,04$ & $*(-15,74--4,60)$ \\
\hline Diabetesgebonden klachten & $(32-160)$ & $(34 / 41)$ & $-10,76$ & $(-21,93 \cdot 0,41)$ \\
\hline
\end{tabular}

- Vermeld wordt het gemiddelde verschil tussen de scores van de experimentele en de controlegroep ( $E-C)$, gebaseerd op de geschatte marginale gemiddelden, met het $95 \%$ betrouwbaarheidsinterval van het gemiddelde verschil. Het gemiddelde verschil is hier significant. Het 95\%-betrouwbaarheidsinterval bevat niet de waarde 0 .

kwaliteit van fèta (Turkse kaas), is er wel een duidelijke verbetering zichtbaar bij de experimentele groep en niet bij de controle groep. Ook het advies met betrekking tot méér bewegen is door de experimentele groep vaak opgevolgd, en in de nameting scoort men dan ook beter dan de controle groep. Datzelfde geldt voor het aantal keren dat men méér dan 30 minuten aan lichaamsbeweging doet: in de experimentele groep is wel een vooruitgang en in de controle groep niet. Vervolgens staan in tabel 2 de door de respondent in de nameting ervaren veranderingen. De experimentele groep ervaart op alle dimensies méér veranderingen dan de controle groep. Dat geldt met name voor het aspect kennis en voor de veranderingen in de zorg. Daarbij valt op dat vrouwen meer veranderingen hebben ervaren dan de mannen. Als laatste uitkomstmaat worden in tabel 2 de diabetes gebonden klachten beschreven. Er is een duidelijke verbetering bij de interventiegroep zichtbaar, maar het verschil met de controlegroep is niet significant. Wel is er een interactie effect van sekse en van leeftijd: met name de vrouwen (verschil: $-19,15$; betrouwbaarheidsinterval: $-33,40--4,90$ ) en de relatief jongeren van de experimentele groep hebben na de interventie minder klachten (verschil: $-17,73$; betrouwbaarheidsinterval: $-34,19-1,24$ ).

\subsection{Discussie}

De interventie heeft een effect gehad op het aantal bezoeken aan de diëtiste. De voorlichtster heeft als intermediair kunnen zorgen dat er afspraken met de diëtiste werden gemaakt én nagekomen. Minder eenduidig is het effect bij de kwaliteit van de communicatie met de huisarts. Voor de vrouwen is de communicatie verbeterd, en voor de mannen zelfs verslechterd. De interventie heeft dus voor vrouwen een positiever effect gehad dan voor mannen. Voor wat betreft de kennis over diabetes en de kennis met 
betrekking tot de adviesonderwerpen, is er geen resultaat zichtbaar bij. Verschillende keren hebben de voorlichtsters ons erop gewezen dat de uitleg van diabetes voor de doelgroep ontzettend complex is, en voor laag geschoolden vaak te moeilijk om te begrijpen. Deze resultaten bevestigen die inschatting. Wel blijkt er een positief effect bij de attitude met betrekking tot de adviesonderwerpen. Het is de voorlichtster gelukt om een positievere houding te bereiken over de juiste voeding en over meer bewegen. Bij de persoonlijke effectiviteit is het niet gelukt om een schaal te construeren. Vrijwel alle veranderingen bij de losse items over persoonlijke effectiviteit wijzen wél in de goede richting. Met betrekking tot de ervaren sociale norm blijkt er niets veranderd. Met betrekking tot de gedragsadviezen heeft de voorlichting op een aantal vlakken effect gehad, met name bij het concrete voedingsadvies en het concrete bewegingsadvies. Bij het aantal eetmomenten, bij de subjectieve beoordeling over het houden aan het dieetadvies en de medicatietrouw (het vergeten van de medicijnen) kon geen effect worden aangetoond omdat de vooruitgang in de controle groep even groot is geweest. Bij de subjectieve beoordelingen over het dieetadvies en het vergeten van de medicijnen, is er een groot risico van sociaal wenselijke antwoorden, ook bij de controlegroep. Met de vragen naar concreet gedrag (hoeveelheid voedsel aan de hand van foto's, het aantal momenten lichaamsbeweging en aantal minuten lichaamsbeweging) kan er een effect worden aangetoond. Dat komt mogelijk omdat bij deze vragen naar concreet gedrag de kans op sociaal wenselijke antwoorden relatief klein is. Bij het aantal eetmomenten is een verbetering zichtbaar bij de beide groepen. Mogelijk is hier ook sprake van een artefact door het onderzoek: door de aandacht van het onderzoek is er door de patiënt, en mogelijk ook door de huisarts, toch méér aandacht besteed aan dit advies. Het aantal eetmomenten is één van de eerste adviezen aan diabetes patiënten, en het komt in voorlichtingsmateriaal ook snel aan bod. Bij de subjectief ervaren veranderingen valt op dat ook hier de vrouwen veel meer veranderingen zeggen te hebben ervaren, dan de mannen, al blijven de mannen ook positief scoren. De laatste set uitkomstmaten in tabel 2 betreft de diabetesgebonden klachten. Ook hier valt het interactie effect met leeftijd en met sekse op: de vrouwen en de jongeren verbeteren het meest.

Over het geheel genomen wijzen de meeste uitkomstmaten in een verwachte, gunstige richting, maar de effecten zijn niet groot. Opvallend is dat de effecten vooral zichtbaar worden bij de vrouwen, en bij de respondenten onder de 50 jaar. In de evaluatie van het effect van de voorlichting op de bloedsuikerwaarden is er een effect aangetoond bij vrouwen; bij mannen is geen effect aangetoond, mogelijk door een daadwerkelijk verschil tussen mannen en vrouwen (Uitewaal e.a., aangeboden). In deze analyse met de gedragsvariabelen is er eveneens een aantal keren interactie met geslacht. Er is reden om aan te nemen dat de voorlichtster met haar gedragsadvisering méér aansluiting heeft gevonden bij de vrouwen dan bij de mannen. Mogelijk omdat de voorlichtster als vrouw meer contact kon maken met haar vrouwelijke patiënten of omdat ze met haar gedragsgerichte advisering bij vrouwen meer aansluiting vond. Ook het effect van de leeftijd kan op diezelfde manier worden geïnterpreteerd: de voorlichtster is zelf relatief jong en vindt bij de jongeren meer aansluiting. Maar mogelijk is ook dat de jongeren hoger zijn opgeleid en daarom beter met de adviezen konden omgaan. 
Als het geheel van alle gedragsvragen, en de vragen naar de determinanten wordt bekeken dan is teleurstellend dat er uiteindelijk veel vragen onbruikbaar bleken in de effectevaluatie. Met name zijn de resultaten bij kennis over diabetes, over de adviesonderwerpen, de persoonlijke effectiviteit, de sociale norm en de intentie met betrekking tot de adviesonderwerpen erg teleurstellend. Een mogelijke verklaring voor dit teleurstellende resultaat is de operationalisatie van de begrippen, en de mate waarin er een cultureel adequate vorm is gevonden. Bij de persoonlijke effectiviteit kon bijvoorbeeld geen schaal worden gevormd. Veel vragen vielen af door een grote non-respons in de nameting omdat de vragenlijst weinig zorgvuldig is ingevuld in de nameting. Meer tijd zou besteed moeten worden aan het valideren en het pretesten van de vragenlijst voor deze doelgroep.

Een andere verklaring voor het teleurstellende resultaat bij de kennisvragen en de determinanten van het gedrag is dat het veronderstelde determinanten model onvoldoende bruikbaar is. De kennis over diabetes, en het inzicht in het waarom van alle adviezen, het belang dat men hecht aan de adviezen, de intentie voor het gedrag, kunnen er bij deze doelgroep minder toe doen dan verondersteld was. Het gebruikte determinantenmodel in dit onderzoek is niet apart van te voren getoetst. Mogelijk is een model voor 'beredeneerd' gedrag van Ajzen voor deze doelgroep niet op de zelfde manier toe te passen. Een migrantenvoorlichtster heeft in de loop van het project wel eens laten ontvallen: De patiënten volgen de adviezen niet omdat ze nu weten waaróm dat moet, maar omdat ik zeg dat ze dat moeten doen! Als het inzicht in het waarom van de adviezen zo complex is, en ook niet vanzelfsprekend, dan zal er een minder 'beredeneerde' weg naar gedragsverandering noodzakelijk zijn (Vergl. De Vries, 2000). Mogelijk is hier sprake is geweest van een perifere route naar attitudeverandering zoals Petty en Cacioppo (1986) beschrijven. Naarmate de argumenten in een persuasieve boodschap niet genoeg aansluiten bijvoorbeeld omdat men de argumenten onvoldoende kan begrijpen, worden de perifere eigenschappen zoals in dit geval de sekse en/of het gedrag van de voorlichtster steeds belangrijker. Het zou ook betekenen dat de attitudeverandering en de gedragsveranderingen in dit onderzoek weinig stevig zijn verankerd, en dat de aanwezigheid van de voorlichtster gewenst blijft om terugval naar ongewenst gedrag te voorkomen. Het is wenselijk dat systematischer voor deze doelgroep wordt nagegaan wat de belangrijkste determinanten zijn van de diabetesgerelateerde gedragingen, en hoe die kunnen worden beĩnvloed.

Over het geheel genomen kan wel worden geconcludeerd dat de migrantenvoorlichtster een bijdrage kan leveren aan adequate zorg voor - tenminste de vrouwelijke - diabetespatiënten. Die bijdrage is een aanvulling op de huisartsenzorg. Het verdient aanbeveling deze methode van diabetesvoorlichting voor de vrouwen breder te implementeren. Voor de mannen moet worden nagegaan hoe zij beter kunnen worden bereikt met de voorlichting over diabetes. Het is denkbaar dat een mannelijke voorlichter wordt getraind en ingezet voor deze diabetesvoorlichting of dat een mannelijk diabetespatiënt een grotere rol krijgt in de voorlichting. 


\section{Literatuur}

Agurs-Collins T.D., Kumanyika S.K., Ten Have T.R., Adams-Campbell L.L. (1997). A Randomised Controlled Trial of Weight Reduction and Exercise for Diabetes Management in Oider African-American Subjects. Diabetes Care; (20) 10: 1503-11.

Ajzen I. (1991). The theory of planned behavior. Organizational Behaviour and Human Decision Processes. 50: 179-211

Arend I.J.M. van den, Schrijvers A.J.P. (1996). Een evaluatie van een educatieprogramma voor type II-diabetespatiënten, dat is ingebed in de zorgverlening. Tijdschr Soc Gezondheidsz; 74,1:32-8.

Brown SA, (1992). Meta-Analysis of Diabetes Patient Education Research: Variations in Intervention Effects across Studies, Res Nursing Health; 15:409-19.

Bruijnzeels MA, Voorham AJJ. De Hoop T. (1999). Migrantenvoorlichting in de huisartspraktijk: een procesevaluatie. Huisarts Wet; 42:307-10.

Corkery E, Palmer C, Foley M. (1997). Effect of a Bicultural Community Health Worker on Completion of Diabetes Education in a Hispanic Population. Diabetes Care; 3: 254-257.

Daniel M.D., Green L.W., Marion S.A., Gamble D., Herbert C.P., Hertzman C., Sheps S. (1999). Effectiveness of community-directed diabetes prevention and control in a rural Aboriginal population in British Columbia, Canada, Soc Sci Med; 48:815-32.

Gerards F. (1993). Health Counseling. In: Damoiseaux V., Van der Molen H.T., Kok G.J. (eds). Gezondheidsvoorlichting en gedragsverandering. Assen: Van Gorcum.

Grootenhuis P.A., Snoek F.J., Heine R.J., Bouter L.M. (1994) Development of a type 2 diabetes symptom checklist: a measure of symptom severity. Diabetic Medicine; 11: 253-61

Hoop T de. Handleiding Interventie Diabetesproject, rapport GGD Rotterdam, Rotterdam: GGD, 1997.

Khanchandani R.A.J., Gillam S. (1999). The ethnic minority linkworker: a key member of the primary health care team?, Br J Gen Practice; 49: 993-4.

Mackenbach J.P. (1996). Migranten, migratie en volksgezondheid. In: Haveman H.B., Uniken Venema P. (red). Migranten en gezondheidszorg. Houten/Diegem: Bohn Stafleu Van Loghum.

Murphy F.G., Anderson R.M., Lyons A.E. (1993). Diabetes Educators as Cultural Translators. The Diabetes Educator, 19,2:113-118.

Petty R.E., Cacioppo R.T. (1986). The elaboration likelihood model of persuasion. Adv Exp Soc Psych, 19:124-205.

Querido J.D. (1995). De prevalentie van diabetes mellitus type II in een achterstandsbuurt, Huisarts Wet 38: 250-3. 
Sturmans F., Voorham A.J.J. (1996). Migrantenvoorlichting en Diabetes bij Turken, een projectvoorstel voor het Programma segv-2. Rotterdam: GGD Rotterdam e.o.

Sweep A, Middelkoop B.J.C., Uniken Venema H.P. (1994). Migranten en hart - en vaatziekten. Rotterdam: GGD Rotterdam e.o

Uitewaal P.J.M., Bruijnzeels M.A., Bernsen R.M.D., Voorham A.J.J., Thomas S. Quality of diabetes care in Dutch general practice for Turkish and Dutch type 2 diabetes patients. (submitted).

Uitewaal P.J.M., Voorham A.J.J., Bruijnzeels M.A., Berghout A., Bernsen R.M.D., Trienekens P.H., Thomas S., Sturmans F. The effectiveness of diabetes peer education for Turkish type 2 patients on glycaemic control: a controlled experiment in general practice. (submitted).

Voorham A.J.J., Uitewaal P.J.M., Hoop T de. (2001). Voorlichting in de eigen taal aan Turkse diabetespatienten; het effect op bloedsuikerwaarden, de ervaren zorg en gedrag. SEGV-rapport 4, Den Haag: Zon/Mw.

Vries, N.K. de. (2000). Het hart, de ruggengraat en de hersenpan. Perspectieven op gezondheidsgedrag. Inaugurele rede, 9 november 2000, Universiteit Maastricht. 

Hoofdstuk 8

De effectiviteit van diversiteit in gezondheidsbevordering 


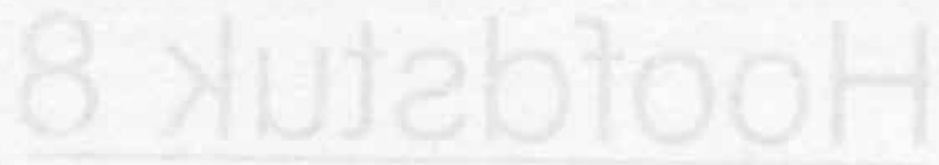

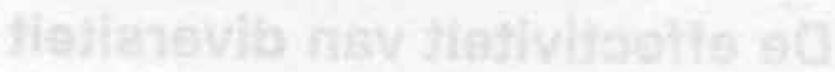

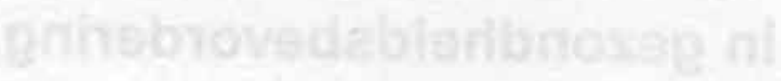




\section{Effectiviteit van diversiteit in gezondheidsbevordering}

\subsection{Inleiding}

Vanuit een sociologisch gezichtspunt heeft McPherson in verschillende samenlevingen de mate van homogeniteit van netwerken onderzocht, dat wil zeggen de mate waarin de individuen in een netwerk dezelfde kenmerken hebben (McPherson e.a., 2001). De conclusie is dat etniciteit de belangrijkste scheidslijn in een samenleving vormt. Vervolgens zijn geslacht, leeftijd, religie en opleiding de belangrijkste kenmerken die relaties structureren. Bij de peer voorlichting of de voor-en-door voorlichting worden leden van de doelgroep ingeschakeld om diezelfde doelgroep te kunnen bereiken. Het is dan ook niet verwonderlijk dat in deze strategie voor gezondheidsbevordering juist de kenmerken die McPherson noemt, als eerste uitgangspunt zijn genomen: leeftijd bij de seniorenvoorlichting, etniciteit en geslacht bij de aidsvoorlichting, en etniciteit bij de diabetesvoorlichting. In de praktische setting van de GGD van Rotterdam is in de afgelopen tien jaar veel ervaring opgedaan met deze methode bij gezondheidsbevordering. Het is bij de GGD Rotterdam welhaast een vast onderdeel van de strategie geworden. Daarin schuilt mogelijk ook een gevaar. Wordt er nog kritisch afgewogen of de peer methode in de concrete situaties de beste keuze is? Of wordt de peer voorlichter gebruikt omdat hij beschikbaar is? Is de betrokken 'peer' dah de best mogelijke? De voorlichtingsstructuur is ontstaan om snel en efficiënt te kunnen reageren op verzoeken en behoeften in de stad. Een poule van voorlichters en voorlichtsters kan op een eenvoudige en snelle manier worden ingezet, en zal dan misschien ook té snel worden ingezet. Het risico bestaat dat de planmatige benadering van het gezondheidsprobleem minder nadruk krijgt. Een kritische reflectie op het gehele proces is daarom van belang. Dat kan onder andere door evaluatieonderzoek te doen, waarbij behalve voor de effectiviteit, ook aandacht is voor het proces waarlangs de effecten zijn bereikt.

\subsection{Drie projecten}

In drie verschillende onderzoeken naar de effectiviteit van de peer methode is aandacht besteed aan de effectiviteit van de voorlichting, en de rol van de peer voorlichter daarbij. Bij seniorenvoorlichting is nagegaan of de gepercipieerde rol van de voorlichter door de deelnemers van invloed is geweest op de effectiviteit. Daarnaast is nagegaan of de seksegelijkheid (i.e. een vrouw geeft voorlichting aan een vrouw, en een man aan een man) van invloed is geweest op de effectiviteit van de voorlichting. Bij aids-voorlichting aan Turkse en Marokkaanse mannen is de effectiviteit van de voorlichting onderzocht. En er is nagegaan welke opvattingen de deelnemers hebben over de voorlichting (vetc) en de voorlichter na de aidsvoorlichting. Deze aidsvoorlichting is noodzakelijkerwijs seksespecifiek georganiseerd geweest: mannen hebben aan mannen voorlichting gegeven. Bij de diabetesvoorlichting is dat niet het geval. Vrouwelijke Turkse voorlicht- 


\begin{tabular}{|c|c|c|c|}
\hline Kenmerken & Project 1: & Project 2: & Project 3: \\
\hline Onderwerp & Succesvol ouder worden & Aids & Diabetes \\
\hline Doelgroep & $\begin{array}{l}\text { Ouderen in Ridderkerk, } \\
\text { mannen en vrouwen }\end{array}$ & $\begin{array}{l}\text { Turkse en Marokkaanse } \\
\text { mannen }\end{array}$ & $\begin{array}{l}\text { Turkse diabetespatienten, } \\
\text { mannen en vrouwen }\end{array}$ \\
\hline Similariteit & $\begin{array}{l}\text { Leeftij: ouderen voor } \\
\text { ouderen. }\end{array}$ & $\begin{array}{l}\text { Elniciteit en migrant zijn: } \\
\text { Turkse en Marokkaanse } \\
\text { mannen voor mannen. }\end{array}$ & $\begin{array}{l}\text { Etniciteit en migrant zijn: } \\
\text { een Turkse voorlichtster } \\
\text { voor Turkse diabetes- } \\
\text { patienten. }\end{array}$ \\
\hline $\begin{array}{l}\text { Zwakte in de } \\
\text { similariteit }\end{array}$ & $\begin{array}{l}\text { Mannen en vrouwen } \\
\text { gemengd }\end{array}$ & Jong en oud gemengd; & $\begin{array}{l}\text { Voorlichtster is zelf gèen } \\
\text { patient; mannen en } \\
\text { vrouwen gemengd }\end{array}$ \\
\hline Context & Buurthuis voor ouderen & Koffiehuis & $\begin{array}{l}\text { Gezondheidscentrum, } \\
\text { huisartspraktijk }\end{array}$ \\
\hline $\begin{array}{l}\text { Doel van de } \\
\text { voorlichting }\end{array}$ & $\begin{array}{l}\text { Verbeteren van het } \\
\text { subjectief welbevinden, } \\
\text { sociale steun, participatie. } \\
\text { houding t.o.v. ouder } \\
\text { worden persoonlijke } \\
\text { effectiviteit, opvaiting over } \\
\text { sociale invloed van } \\
\text { ouderen. }\end{array}$ & $\begin{array}{l}\text { Wegnemen van mis. } \\
\text { verstanden en barrières, } \\
\text { verbeteren van persoonlijke } \\
\text { effectiviteit en intentie } \\
\text { tot condoomgebruik. }\end{array}$ & $\begin{array}{l}\text { Verbeteren van bloed- } \\
\text { suikerwaarden, } \\
\text { gedragsverandering } \\
\text { met betrekking tot } \\
\text { voeding, bewegen } \\
\text { en medicingebruik } \\
\text { in relatie tot diabetes. }\end{array}$ \\
\hline $\begin{array}{l}\text { Vorm van de } \\
\text { voorlichting }\end{array}$ & $\begin{array}{l}\text { Groepsbijeenkomsten: } \\
\text { vier keer, op uitnodiging. } \\
\text { enigszins formeel. }\end{array}$ & $\begin{array}{l}\text { Koffiehuisvoorlichtingen: } \\
\text { ad hoc georganiseerde } \\
\text { 'open' bijeenkomst }\end{array}$ & $\begin{array}{l}\text { Driegesprekken met arts, } \\
\text { individuele begeleiding } \\
\text { en groepsbijeenkomsten. }\end{array}$ \\
\hline $\begin{array}{l}\text { Rol van de } \\
\text { voorlichter }\end{array}$ & $\begin{array}{l}\text { De voorlichter doet } \\
\text { een expliciet beroep op } \\
\text { een wijgevoel als ouderen } \\
\text { ondering. }\end{array}$ & $\begin{array}{l}\text { Afhankeilik van het publiek } \\
\text { doet de voorlichter expliciet } \\
\text { een beroep op een gemeen } \\
\text { schappelijke etniciteit en het } \\
\text { migrant zijn }\end{array}$ & $\begin{array}{l}\text { De voorlichtster stelt zich } \\
\text { op de eerste plaats op } \\
\text { als intermediair die kan } \\
\text { heipen met de taal; } \\
\text { op de tweede plaats } \\
\text { ais Turkse migrant. }\end{array}$ \\
\hline $\begin{array}{l}\text { Gedrag in } \\
\text { relatie tot het } \\
\text { doel }\end{array}$ & $\begin{array}{l}\text { De voortichter spreekt } \\
\text { vanuit haar eigen ervaring } \\
\text { van het ouder worden. }\end{array}$ & $\begin{array}{l}\text { De voorlichter moet kiezen } \\
\text { om wellgeen condoom- } \\
\text { demonstratie te geven, } \\
\text { wel/ geen bedekte termen. } \\
\text { te gebruiken. }\end{array}$ & $\begin{array}{l}\text { De voorfichtster kan } \\
\text { beperkt vanuit eigen } \\
\text { ervaring praten. }\end{array}$ \\
\hline $\begin{array}{l}\text { Organisatie/ } \\
\text { opdrachtgever }\end{array}$ & $\begin{array}{l}\text { GGD/ Stichting Welzijn } \\
\text { Ouderen Ridderkerk }\end{array}$ & $\begin{array}{l}\text { GGD: de voorilichter } \\
\text { presenteert zich expliciet ats } \\
\text { medewerker van de GGD. }\end{array}$ & Gezondheidscentrum/GGD \\
\hline $\begin{array}{l}\text { Onderzoeks- } \\
\text { vraag offect }\end{array}$ & $\begin{array}{l}\text { Is de voorlichting over } \\
\text { succesvol ouder worden } \\
\text { effectief? }\end{array}$ & $\begin{array}{l}\text { Is de voorlichting over Aids } \\
\text { effectief? }\end{array}$ & $\begin{array}{l}\text { Is de begeleiding van de } \\
\text { voorlichtster effectief? }\end{array}$ \\
\hline $\begin{array}{l}\text { Onderzoeks- } \\
\text { vraag proces }\end{array}$ & $\begin{array}{l}\text { Wordt de voorlichter door } \\
\text { de doelgroep ervaren als } \\
\text { peer voorlichter? is er een } \\
\text { relatie tussen die ervaring } \\
\text { van de doelgroep en de } \\
\text { effectiviteit van de } \\
\text { voorlichling? is sekse- } \\
\text { homogeniteit (mannen } \\
\text { voor mannen, vrouwen } \\
\text { voor vrouwen) voordelig } \\
\text { voor de effectiviteit? }\end{array}$ & $\begin{array}{l}\text { Wordt de voorlichter door } \\
\text { de doelgroep ervaren } \\
\text { ais peer voorlichter? } \\
\text { Is het taboeonderwerp } \\
\text { bedreiging voor het } \\
\text { een peerschap? }\end{array}$ & $\begin{array}{l}\text { Wordt de voorlichter door } \\
\text { de doelgroep ervaren als } \\
\text { peer voorlichter? } \\
\text { Is er een verschil tussen } \\
\text { mannen en vrouwen? } \\
\text { (seksehomogeniteit) }\end{array}$ \\
\hline
\end{tabular}


sters gaven voorlichting aan Turkse mannelijke en vrouwelijke diabetespatiënten. Daarbij kon onderzocht worden of er een seksespecifiek effect was. Ofwel, was de voorlichtster met de betreffende voorlichting voor vrouwen effectiever dan voor mannen? In schema A worden de kenmerken van de projecten weergegeven.

\subsection{Interventie(theorie) bij gezondheidsbevordering}

De redenering over aanbevelingen op basis van evaluatieonderzoek volgt vaak de volgende logische lijn, zoals bijvoorbeeld bij het programma Preventie van Zorg Onderzoek Nederland/Medische Wetenschappen (ZonMw). Nadat de determinanten zijn beschreven (deelprogramma 1), wordt er een experimentele interventie geëvalueerd (deelprogramma 2), en daarna wordt nagegaan hoe de effectieve interventie kan worden geïmplementeerd (deelprogramma 3 en 4) (ZonMw, 1998 en 2001). Als er bij de experimentele interventie geen of weinig effect is aangetoond dan moet gezocht worden naar de oorzaken daarvan, om tot beter onderzoek en/of tot een betere interventie te komen. En die twee gaan ook vaak samen: goed onderzoek leidt tot effectieve interventies omdat goed onderzoek planmatigheid vereist, en andersom bij planmatige interventies is goed onderzoek relatief gemakkelijk in te bouwen en uit te voeren. In het proces van 'intervention mapping' wordt deze wederzijdse afhankelijkheid goed beschreven en uitgebuit (Bartholomew e.a., 2001). Vandaar het algemeen aanvaarde adagium in gezondheidsbevordering: planmatigheid leidt totreffectiviteit. Als de effectiviteit van een interventie niet ter discussie staat dan is het advies om de randvoorwaarden van implementatie te onderzoeken. En in een goed interventieontwikkelingsproces wordt al op de implementatie vooruitgelopen (Bartholomew e.a., 2001). Het heeft geen zin om effectieve interventies te ontwikkelen die vervolgens niet verspreid kunnen worden (vergl. Voorham \& Reelick, 1986). In deze systematiek gaat men ervan uit dat de interventie onder controle herhaalbaar is binnen de randvoorwaarden die in het experiment zijn beschreven. Een vraag die maar zelden wordt gesteld, is wát er dan wordt herhaald. In een experiment wordt een model van een interventie (een aantal malen) vertaald in praktische activiteiten. Dat wil dus zeggen dat het proces van het toepassen van een model van de interventie in een concrete situatie, wordt herhaald. Ofwel, een effectieve interventie is niks meer, maar ook niks minder is dan een valide theorie over de wijze waarop bij een bepaalde doelgroep in een bepaalde situatie onder bepaalde condities een bepaald effect kan worden bereikt. En hoe beter deze interventietheorie beschreven is, hoe beter de interventie herhaalbaar is. In de verslagen, handleidingen, draaiboeken, die meestal van een effectieve interventie worden overgedragen, moet juist deze theorie goed beschreven worden. Evaluatieonderzoek is het toetsen van een interventietheorie. Het evaluatieonderzoek moet antwoord geven op de vraag in hoeverre de interventietheorie gegeneraliseerd kan worden naar plaats, tijd, onderwerp, doelgroep, doel, etc. De vertaling van een experimentele interventie in een implementatieproces is niet hetzelfde als een interventie simpelweg heel vaak te herhalen. Er is een vertaalslag nodig die de werkzame elementen van de experimentele interventie in een implementatieplan verwerkt. De werkzame elementen kunnen via een 
vertaalslag bruikbaar zijn voor de implementatie van de interventie, ook in nieuwe situaties en onder andere randvoorwaarden, afhankelijk van de veronderstelde geldigheid van de interventietheorie.

Aanbevelingen op basis van de resultaten van evaluatieonderzoek kunnen gaan over de concrete interventie die in het experiment is uitgevoerd, bijvoorbeeld de Turkse voorlichter die in de setting van een koffiehuis aidsvoorlichting geeft. De aanbevelingen kunnen gaan over aanpassingen van zijn gedrag, over het gebruikte materiaal, over de setting, maar het is steeds ongeveer dezelfde interventie. Tot aan welk punt blijt een interventie min of meer hetzelfde: koffiehuizen met jong en oud publiek, politiek links en rechts? Voor welke verzameling van concrete interventies geldt de generalisatie? Het experiment met aidsvoorlichting in de koffiehuizen zegt ook iets over de haalbaarheid van een ander onderwerp in die setting met die doelgroep. Dat is geen aanbeveling over aidsvoorlichting maar over een methode om de doelgroep te bereiken, los van dit concrete onderwerp, ook relevant voor toekomstige andere interventies in andere settings, met andere doelen en doelgroepen. Deze laatste algemenere aanbevelingen zijn voor gezondheidsbevordering van groter belang omdat alleen op die manier aan bredere implementatie kan worden gewerkt. Ze zijn tijdlozer en minder context gevoelig, maar het vereist tegelijkertijd veel expertise op het gebied van interventieontwikkeling om dit model van de interventie te kunnen vertalen in een praktische interventie. Deze aanbevelingen zijn relevanter voor de theorievorming rond interventies. En die theorievorming is voor gezondheidsbevordering belangrijk omdat resultaten uit evaluatieonderzoek vaak moeten worden vertaald in een veranderende praktijk. Dit verschil in soorten aanbevelingen verklaart ook de aarzeling van gezondheidsbevorderaars om 'elders effectief gebleken interventies' te gebruiken, omdat meestal wordt bedoeld dat de geplande interventies dan gemakkelijker en goedkoper zullen zijn. De eigen situatie wordt snel uniek gevonden waardoor 'standaard' oplossingen niet bruikbaar zijn. Het gevolg is het 'not-invented-here-syndrome' waarbij men het gevoel heeft dat de interventies die niet zelf zijn ontwikkeld niet op de eigen situatie passen. In een goed implementatieproces wordt een interventie steeds weer opnieuw 'uitgevonden' in de nieuwe situatie onder andere nieuwe randvoorwaarden. De omgekeerde situatie komt óók voor, namelijk dat zonder de theorie achter de interventie te kennen, klakkeloos een interventie wordt overgenomen in een setting die te veel verschilt van het geëvalueerde experiment. Vermoedelijk loopt dat uit op een teleurstelling.

Samenvattend zijn er dus voor elk project aanbevelingen te formuleren voor een herhaling van een verbeterd experiment. Maar er zijn ook aanbevelingen te formuleren die de interventietheorie betreffen, los van de concrete situatie in het experiment. Er kan dan meer rekening worden gehouden met de veranderende praktijk. Het verschil in aanbevelingen is vergelijkbaar met de stappen die worden genomen in het proces van intervention mapping' (Bartholomew e.a., 2001). Daarbij kunnen aanbevelingen worden gedaan over het 'programmaplan', het meest concrete interventieniveau, maar óók over het niveau van de methoden en strategieën. In de systematiek van ZonMw kan de stap van een effectief gebleken interventie naar implementatie beter op de volgende manier worden opgevat. Implementatieprocessen vergen altijd een complex van verschillende, 
effectief gebleken interventies die tegelijkertijd beschikbaar zijn: scholing en training. materiaal, voorlichtingsactiviteiten, draaiboeken, wervingsstrategieën, etc. Ook al heeft de experimentele interventie in de praktijk plaatsgevonden, er is vaak maar één onderdeel, namelijk de experimentele factor, goed onderzocht. Uit andere experimenten moet de evidentie komen voor de onderdelen die in het experiment niet zijn onderzocht maar die in de implementatie wel noodzakelijk zijn. Implementatieonderzoek moet dus altijd gaan over meerdere effectief gebleken interventies of interventieonderdelen. De generaliseerbaarheid van de evidentie uit het evaluatieonderzoek moet steeds zodanig beschreven zijn dat die interventie losser van concrete situaties kunnen worden toegepast. De wereld staat niet stil terwijl er evaluatieonderzoek wordt gedaan. Goed evaluatieonderzoek gaat over cruciale keuzemomenten die voor de uitvoering van een grotere strategie van belang zijn. Een interventie is als een theoretische constructie die in verschillende praktische velden tot concrete activiteiten wordt gemaakt. Dat proces problematiseren en onderzoeken is belangrijk voor onderzoek en implementatie! Nadenken en rapporteren over de generaliseerbaarheid van deze interventietheorieën is een belangrijke randvoorwaarde voor de groei van kennis op het gebied van gedragsgerichte gezondheidsbevordering. Er loopt geen simpele rechte lijn tussen een effectief gebleken interventie, en de implementatie van diezelfde interventie.

\subsubsection{Project 1: Seniorenvoorlichting: Succesvol ouder worden}

Bij de start van de seniorenvoorlichting zocht men in eerste instantie extra voorlichtingscapaciteit om te kunnen voldoen aan een informatiebehoefte bij de autochtone ouderen. Op deze wijze heeft de GGD Rotterdam vele jaren aan voorlichtingsverzoeken in de wijken kunnen voidoen, over een groot aantal onderwerpen zoals hart - en vaatziekten, vergeetachtigheid, de WVG (Wet Voorzieningen Gehandicapten). De seniorenvoorlichter werd in die situatie vooral aangesproken op zijn of haar deskundigheid met betrekking tot het voorlichtingsonderwerp. Pas in tweede instantie ging het in die eerste fase om het model van de peervoorlichter en zijn ervaringskennis als senior. In het experiment met 'Succesvol ouder worden' is het peerschap belangrijker geworden omdat de ervaringskennis in het onderwerp een veel grotere rol ging spelen: Hoe kijk je aan tegen ouder worden? Wat zijn elementen van succesvol ouder worden? Wat betekent het om 'manager van het eigen bestaan' te zijn? Daarin zijn de doelstellingen met betrekking tot persoonlijke effectiviteit en sociale invloed van ouderen ('empowerment') duidelijker te herkennen. Bij deze cursus in Ridderkerk is in het evaluatieonderzoek een effect vastgesteld op opvattingen van ouderen over de sociale invloed van ouderen, op de ervaren sociale steun en de subjectieve gezondheidsbeleving van de deeinemers. Geconcludeerd kon worden dat senioren-voorlichting een bijdrage levert aan het realiseren of in stand houden van de voorwaar-den sociale steun en manager van het eigen bestaan. Dat zijn twee van de voorwaarden voor 'succesvol ouder worden' uit de zogenaamde 'schijf van succesvol ouder worden' (De Groot, 1990; Kocken \& Voorham, 1998). Deze vorm van seniorenvoorlichting grijpt echter niet aan op alle determinanten van gedragsver-ande-ring in het model van beredeneerd gedrag, te weten attitude, eigen effectiviteit en sociale invloed. Uiteindelijk heeft de cursus een bescheiden effect 
gehad op de uitkomstvariabelen (Kocken, 2000). Naast de effectevaluatie is ook nagegaan of de subjectieve rol van de voorlichter zoals gepercipieerd door de respondent én de objectieve seksegelijkheid (een mannelijke voorlichter met een mannelijke deelnemer en een vrouwelijke voorlichter met een vrouwelijke deelnemer) van invloed is op de effectiviteit van de voorlichting. De mening over de voorlichter is over het algemeen positief. Bij geen enkel item oordeelt het grootste deel van de groep negatief. In hoeverre is het subjectieve beeld van de peervoorlichter en de objectieve seksegelijkheid van invloed op het effect van de voorlichting? Voor de meeste uitkomstvariabelen wordt aangetoond dat vooral de seksegelijkheid positief samenhangt met de effectiviteit van de voorlichting. Bij gelijke sekse van voorlichter en voorgelichte is er een groter effect van de voorlichting. De subjectieve mening over de rol van de voorlichter speelt als voorspeller van effect een minder grote rol, en heeft een aantal maal een onverwachte richting. Deze seniorenvoorlichting kan beter seksespecifiek worden georganiseerd door mannengroepen en vrouwengroepen samen te stellen (Voorham en Kocken, 2000). In de groep van seniorenvoorlichters is er een tweedeling zichtbaar van de voorlichters die een voorkeur hebben voor de expertrol in de voorlichting (Vooral de mannen!), en de voorlichters die zich meer thuis voelen bij een procesrol (Vooral de vrouwen!). Wat verklaart nu het seksespecifieke effect in de voorlichting? Is dat het gedrag of de sekse van de voorlichter? In dit experiment is het gedrag van de voorlichters en voorlichtsters niet direct geobserveerd zodat daarover geen uitspraak kan worden gedaan. Om meer inzicht te krijgen in het seksespecifieke effect zou het wenselijk zijn de interventies nauwkeuriger te monitoren om voortdurend terugkoppeling te hebben over de gerealiseerde interventies. Welke implicaties zijn er voor de praktijk van de seniorenvoorlichting? De laatste jaren neemt de vraag naar seniorenvoorlichting over specifieke gezondheidsonderwerpen af. De indruk bestaat dat de jongere ouderen relatief goed zijn geïnformeerd, en ook gemakkelijker internet of andere bronnen voor informatie kunnen raadplegen. De GGD in Rotterdam is bezig met een herbezinning op de uitgangspunten en een heroriëntatie op de mogelijkheden van de seniorenvoorlichting. Wat kan er op basis van het evaluatieonderzoek gezegd worden over seniorenvoorlichting in het licht van deze ontwikkeling? De algemene aanbeveling is dat bij de seniorenvoorlichting het peerschap beter benut kan worden door meer gebruik moet maken van ervaringskennis van de ouderen en de voorlichters en de ouderen zelf een grotere rol te geven bij de keuze van thema's en de uitvoering. Steeds moet de vraag gesteld worden of de voorlichtingsactiviteiten seksespecifiek georganiseerd kunnen worden. Op dit moment loopt het experiment 'In Samenspraak' waarbij het zogenaamde activerend huisbezoek voor ouderen wordt geëvalueerd en waarbij onder andere de seniorenvoorlichters worden ingeschakeld als huisbezoeker. Het activerend huisbezoek is voor de seniorenvoorlichter een nieuwe werkvorm waarvan in dit project wordt nagegaan welke doelstellingen bereikt kunnen worden. Op het eerste gezicht lijkt het activerend huisbezoek een werkvorm waarbij het peerschap goed benut kan worden (GGD Rotterdam, 2000). In die situatie is het waarschijnlijk wenselijk dat de peer voorlichters uit de directere omgeving van de doelgroep van ouderen worden geworven. Een stedelijke poule van voorlichters ligt dan minder voor de hand. Het project krijgt dan kenmerken van een community 
aanpak. Een geheel andere invalshoek voor de toepassing van seniorenvoorlichting is het projectvoorstel 'Zin in Gezond Leven' van de Universiteit voor Humanistiek waarbij de vraag is of en in hoeverre onderwerpen rond zingeving een rol spelen in 'gezond leven' bij allochtone en autochtone ouderen (Universiteit voor Humanistiek, 2001). Voor de seniorenvoorlichting, en voor de geldigheid van de interventietheorie, betreft dit nieuwe toepassingen met andere werkvormen (activerend huisbezoek, tweegesprekken), andere onderwerpen (zingeving), en een andere doelgroep (allochtone ouderen). Ook in die toepassingen kan het peerschap een grote rol spelen.

\subsubsection{Project 2: Aidsvoorlichting aan Turkse en Marokkaanse mannen}

De Aidsvoorlichting had tot doel de kennis over transmissie en preventie van aids te vergroten, misverstanden en onnodige angst weg te nemen, evenals de houding en eigen effectiviteit ten aanzien van condoomgebruik te veranderen. De vraagstelling van het effectonderzoek was: wat is het effect van aidsvoorlichting in de eigen taal aan Turkse en Marokkaanse mannen met betrekking tot kennis, attitude, eigen effectiviteit en intentie ten aanzien van aids en aids-preventief gedrag? Geconcludeerd kan worden dat de kennis over misverstanden rond transmissie van Aids en over risicosituaties en strategieën ter preventie van Aids door de voorlichting toegenomen is (Kocken e.a., 2001). Zowel bij Turken als Marokkanen kan voorlichting winst bereiken op het terrein van misverstanden over transmissie. Bij Turken is kenniswinst te behalen op het gebied van de beschermende werking van condooms. De kennis over de incubatietijd van het HIV-virus en het testbeleid t.a.v. prostituees blijft bij Turken en Marokkanen, ook na de voorlichting, relatief gering. Het effect op de doelstellingen die condoomgebruik betreffen is gering en verdwijnt na correctie voor het groepseffect door middel van een multilevel analyse. Het effect op kennis over de beschermende werking van condooms bij Turken en op eigen effectiviteit en intentie m.b.t. condoomgebruik bij Marokkanen verdwijnt in de multile-vel analyse. Een effect op attitude t.a.v. condoomgebruik ontbreekt. Het is opvallend dat bij Marokkanen vooraf aan de voorlichting (controle-groep) de kennis over Aids groter is dan bij Turken. Ook beschouwen ze hun eigen effectiviteit als hoger. Echter, de attitude t.a.v. condooms en intentie tot condoomgebruik is lager dan bij Turken. Uit de analyses op het niveau van het individu blijkt dat de verschillen tussen de experimentele en controlegroep het grootst zijn bij respondenten die 30 jaar zijn of ouder, die niet eerder Aids-voorlichting hebben gehad, met een laag opleidingsniveau en die belang hechten aan voorlichting in de eigen taal en cultuur. Er zijn ook een aantal vragen gesteld over kenmerken van de voorlichter en de voorlichting (Voorham e.a., 2002). Na de voorlichting vindt driekwart van de Turkse en Marokkaanse mannen in de koffiehuizen het belangrijk dat de voorlichter hun eigen taal spreekt en hun eigen cultuur kent. Dat is een bemoedigend gegeven voor de voorlichting in de eigen taal. Het aanbod van de voorlichting in de eigen taal voldoet aan een behoefte. Marokkanen geven méér dan de Turken de voorkeur aan voorlichting door een Nederlander met een tolk in plaats van door een aidsvoorlichter in de eigen taal. In de praktijk van de migrantenvoorlichting blijkt dat voorlichtingsgroepen voor Marokkanen moeilijker tot stand komen en minder goed bezocht worden dan de voorlichtingsbijeenkomsten voor Turken. 
Mogelijk is de voorkeur voor een tolk een deel van de verklaring voor dit verschil. Een andere verklaring voor dit verschil is het probleem van de dialecten. De Marokkanen die Berber spreken zullen de voorlichter die Marokkaans - Arabisch spreekt met moeite verstaan, en andersom. Bij de vraag over het vertrouwen in de voorlichter -die men dus net heeft zien optreden - blijkt er geen verschil tussen Turken en Marokkanen. De 'voorlichter als voorbeeld' laat echter een duidelijk verschil zien. Alleen bij de voorlichtingsbijeenkomsten waarbij het condoomgebruik beperkt en met bedekte termen behandeld is, zien de Turken hun voorlichter minder als voorbeeld dan de Marokkanen. Over de richting van deze samenhang kan op basis van dit onderzoek geen conclusie worden getrokken. Het is mogelijk dat de Turken gevoeliger zijn voor de opstelling van de voorlichter, en dat de bedekte bespreking van het condoomgebruik ertoe leidt dat men de voorlichter niet als voorbeeld ziet. De Turkse voorlichter is dan blijkbaar té voorzichtig geweest. Het kan ook zijn dat de voorlichter weinig aansluiting voelt bij het publiek, en zich minder een voorbeeld voelt, en als resultaat daardoor méér bedekte termen gaat gebruiken. In dit project heeft gelijkheid ook grenzen. De voorlichter en voorgelichte hebben dezelfde culturele achtergrond maar toch moet ook het verschil in opleiding en ervaring in aanmerking worden genomen. De voorlichters eigen taal hebben een opleiding tot Aids-voorlich-ter genoten. Zij oefenen in het dagelijks leven allen een beroep uit, vaak op HBO-niveau. Door de bezoekers worden de voorlichters eigen taal als deskundigen van de GGD gezien. Dit schept mogelijk afstand. Voor de afstand met betrekking tot het opleidingsniveau zijn echter geen aanwijzingen gevonden. Lager opgeleiden hebben zelfs in hogere mate baat bij de voorlichting. Wel blijkt dat de voorlichting minder goed aanslaat bij responden-ten, jonger dan 30 jaar. Mogelijk is de voorlichting onvoldoende toegesneden op hun kennisniveau en behoeften. De vraag kan worden gesteld of de voorlichters die veelal ouder zijn dan 30 jaar voldoende aansluiting hebben gehad bij deze jonge doelgroep. Samenvattend, kan bij deze Aidsvoorlichting voor en door de Turkse en Marokkaanse mannen het peerschap worden versterkt door te onderscheiden naar leeftijd. Met name lijkt het van belang te zoeken naar méér aansluiting bij de jongeren, dus door jongere voorlichters te werven en te trainen. Het kan ook nog dat het determinantenmodel van condoomgebruik voor de jongeren nog onvoldoende voldeed.

Welke implicaties hebben deze conclusies voor de interventietheorie en voor de praktijk van de aidsvoorlichting? De Aidsvoorlichting voor en door Turkse en Marokkaanse mannen is ontstaan vanuit de noodzaak dat deze voorlichting seksespecifiek en etnisch specifiek (in de eigen taal) georganiseerd moest worden. Het experiment in de koffiehuizen laat zien dat deze vorm van koffiehuisvoorlichtingen een bijdrage kan hebben aan het wegnemen van misverstanden en het verbeteren van risico-inschattingen maar dat de interventie onvoldoende effectief is om gedragsverandering te bereiken. Intussen is de voorlichting door-en-voor Turkse en Marokkaanse mannen 'verbreed', dat wil zeggen dat de voorlichters ook getraind zijn om over andere onderwerpen voor te lichten. Een van de mogelijke manieren om de effectiviteit van de peer voorlichting over aids te verhogen is teruggaan naar de oorsprong, in dit geval de community benadering. Behalve de uitvoering van de concrete voorlichtingsbijeenkomsten in koffiehuizen is het 
denkbaar dat de etnisch specifieke organisaties in de betrokken wijken c.q. deelgemeenten worden betrokken bij de organisatie van de voorlichting. Op die manier kan er een evenwichtiger interventiemix worden nagestreefd. Denkbaar is dat opinieleiders worden getraind, dat lokale massamedia worden gebruikt. Zo'n aanpak wordt toegepast in het experiment Amor i Salu (Kocken e.a., 2003). Het betreft een etnisch specifiek community project voor Antillianen en Arubanen ter preventie van Aids, soa en ongewenste zwangerschappen. Het is niet toevallig dat deze strategie voor deze doelgroep is gekozen want voor Antillianen bestaat er geen koffiehuiscircuit waar een voorlichter relatief eenvoudig kan aankloppen om de doelgroep te vinden. Voor de Antillianen en Arubanen in Rotterdam kan dat wel via manifestaties, via buurthuisactiviteiten, via lokale media (radio en posters), etc. Ook de aidsvoorlichting voor de Turkse en Marokkaanse mannen kan via dezelfde strategie versterkt worden door de zelforganisaties, de moskeeverenigingen, sociaal-culturele verenigingen, sportverenigingen en andere mogelijke kanalen, te betrekken bij de preventie van aids en soa in de betreffende gemeenschappen. In dat geval kunnen de mannen en de vrouwen in dezelfde buurt simultaan worden benaderd over Aids en soa. Dat zal effectverhogend zijn. De Aidsvoorlichting aan Turkse en Marokkaanse vrouwen is steeds belemmerd geweest door de vraag welke concrete gedragsverandering aan de vrouwen kon worden geadviseerd. Ook als een vrouw zou weten dat haar man wisselende seksuele kontakten heeft, dan nog is het voor haar erg lastig om haar man te vragen een condoom te gebruiken. In een bredere community aanpak kan die Aidsvoorlichting voor-en-door vrouwen ook beter uit de verf komen.

\subsubsection{Project 3: Diabetesvoorlichting voor Turkse mannen en vrouwen}

In het diabetesproject hebben Turkse migrantenvoorlichtsters samen met de betrokken huisartsen de Turkse mannelijke en vrouwelijk diabetespatiënten begeleid, en gemotiveerd tot het opvolgen van de adviezen met betrekking tot voeding, bewegen en medicijngebruik teneinde een goed ingestelde bloedsuikerwaarde te bereiken. Het evaluatieonderzoek toont een bescheiden positief effect aan van migrantenvoorlichting in de huisartspraktijk op de glycaernische instelling ( $\mathrm{HbA1c}$ ) van Turkse diabetespatiënten (Voorham e.a., 2001; Uitewaal e.a., submitted). Dat effect is het meest uitgesproken bij vrouwen. In deze studie zijn alle Turkse diabetespatiënten ingesloten die uitsluitend door de huisarts werden gezien. Er is geen verbetering bij de patiënten met relatief goed ingestelde bloedsuikerwaarde, maar een bescheiden verbetering bij de patiënten met een verhoogde $\mathrm{HbA1c}$ waarde. $\mathrm{Er}$ is geen verbetering bij de mannen zichtbaar, mogelijk doordat de mannen in de nulmeting een relatief lage $\mathrm{HbA1c}$ hebben. Mogelijk is hier óók sprake van een seksespecifiek effect. De interventie heeft een effect gehad op de communicatie met de huisarts en het aantal bezoeken aan de diëtiste. Bij de kwaliteit van de communicatie met de huisarts is er een interactie met sekse: voor de vrouwen is de communicatie verbeterd, maar voor de mannen zelfs verslechterd. Met betrekking tot de gedragsadviezen heeft de voorlichting effect gehad bij het voedingsadvies en het advies met betrekking tot bewegen. Juist met de vragen naar concreet gedrag (hoeveelheid voedsel aan de hand van foto's, het aantal momenten en aantal 
minuten lichaamsbeweging) kan er een effect worden aangetoond. Bij deze vragen naar concreet gedrag is de kans op sociaal wenselijke antwoorden relatief klein. Bij het aantal eetmomenten is een verbetering zichtbaar bij zowel de interventiegroep als de controle groep. Mogelijk is hier sprake van een artefact door het onderzoek: door de aandacht van het onderzoek is er door de patiënt, en mogelijk ook door de huisarts, toch meer aandacht besteed aan dit advies. Het aantal eetmomenten is één van de eerste adviezen aan diabetes patiënten. En in voorlichtingsmateriaal komt het snel aan bod. Bij de diabetesgebonden klachten valt weer een interactie effect op, dit keer met sekse én met leeftijd. De vrouwen en de jongeren verbeteren het meest.

Over het geheel genomen wijzen de meeste uitkomstmaten in een verwachte, gunstige richting. Echt opvallend is dat de effecten vooral zichtbaar worden bij de vrouwen, en bij de respondenten onder de 50 jaar. Dat is reden om aan te nemen dat de gedragsgerichte interventie met de vrouwelijke voorlichtster méér aansluiting heeft kunnen vinden bij de vrouwen dan bij de mannen. Het leeftijdspecifieke effect kan op diezelfde manier worden geïnterpreteerd: de voorlichtster is zelf relatief jong en vindt bij de jongeren meer aansluiting. In de vragenlijst zijn aan de respondenten ook vragen gesteld over de voorlichtsters (Voorham e.a., 2001). Die zijn echter zodanig positief beantwoord dat ze niet als procesvariabelen konden worden meegenomen in de analyse. De vraag of de voorlichting beter in het Nederlands gegeven had kunnen worden, beantwoorden alle patiënten met 'nee'. De beide voorlichtsters vertellen in begeleidingsgesprekken dat veel patiënten blij waren dat ze in eigen taal met iemand in de huisartspraktijk over hun klachten en problemen konden spreken, dat ze de voorlichtster wel voor ál hun klachten wilden spreken. Zij gaven duidelijk aan opgelucht te zijn omdat er nu geen taalbarrière was die het bespreken van de diabetes hinderde. In de vragenlijst kruisen vrijwel alle patiënten (mannen en vrouwen) de uitspraak "de voorlichtster was als een goede vriendin" als waar aan. Alle respondenten vonden dat de voorlichtster een voorbeeld voor hen was; ze hadden bijna allemaal vertrouwen in haar kundigheid. Het bleek voor de voorlichtsters goed mogelijk om ook regelmatige consulten met mannen te realiseren en met hen een vertrouwensband op te bouwen. Sekseverschil leek op dit punt geen beperking. Wel bestond bij de voorlichtsters de indruk dat de mannen een andere voorlichtingsbehoefte hadden dan de vrouwen. Mogelijk zagen de mannen de huisarts als de échte deskundige, en voelden zij zich enigszins 'afgescheept'. In dit project is de voorlichtster een peer vanwege het feit dat ze ook Turkse migrant in Rotterdam is. Ze is zelf geen diabetespatiënte. Gezien de omvang van het gezondheidsprobleem lijkt het haalbaar om bij de diabetesvoorlichting voor de vrouwen een etnisch specifieke diabetespatiënte in te zetten. Tot die tijd kan de Turkse gezondheidsvoorlichtster haar effectiviteit vergroten door méér seksespecifiek lotgenotencontact te organiseren in haar begeleidingstraject. Voor de mannen is nog onduidelijk of ze voldoende via de peermethode kunnen worden bereikt, en of het versterken van lotgenotencontact de beste weg is. Het is ook denkbaar dat de huisarts met behulp van een tolk een betere oplossing is.

Wat betekenen deze conclusies voor de interventietheorie? Het diabetesproject is een verbijzondering van migrantenvoorlichting voor en door vrouwen op twee manieren. Op 
de eerste plaats is het een toepassing van migrantenvoorlichting door en voor vrouwen in de huisartspraktijk, en dus niet in buurthuis of bij een migrantenzelforganisatie. Op de tweede plaats is het een verbijzondering omdat het over diabetes gaat, en over het motiveren tot gedragsverandering, en het gaat niet over de 'traditionele' voorlichtingsonderwerpen voor de migrantenvoorlichtsters zoals het menselijk lichaam of vrouwenklachten (Al kunnen die onderwerpen in het proces zeker nog een rol spelen!). Er is al langere tijd een ontwikkeling gaande van de basisonderwerpen (zoals het menselijk lichaam, zwangerschap en bevalling, kinderverzorging en opvoeding) naar meer specifieke onderwerpen. In de groepsvoorlichting in buurthuizen is dat een ontwikkeling naar maatschappelijk georiënteerde onderwerpen, zoals omgaan met geld. In de eerste lijn is die ontwikkeling in de richting van de gezondheidsklachten die vaak voorkomen. De belangrijkste onderwerpen die daarbij aan bod komen zijn: psychosomatische klachten. astma en diabetes (Bruijnzeels e.a., 1998). Om de effectiviteit van de inzet van de voorlichtsters in de eerste lijn aan te tonen, is gekozen voor een opzet waarbij gezondheidswinst aannemelijk gemaakt zou kunnen worden. De idee bij die keuze was dat de evaluatie van de diabetesbegeleiding zou kunnen worden gezien als een 'pars pro toto' voor de inzet bij andere relatief concrete adviesonderwerpen zoals astma, overgewicht of hoge bloeddruk. Als een verbijzondering van complexe advisering wordt op dit moment de begeleiding door de voorlichtster van Turkse en Marokkaanse vrouwelijke patiënten met psychosomatische klachten geëvalueerd (Project Bruggen Bouwen). Deze voorlichting wordt dus seksespecifiek georganiseerd. En dat kan als algemenere aanbeveling vanuit de diabetesvoorlichting gelden: waar mogelijk en in ieder geval voor vrouwen liever seksespecifiek.

Onder invloed van de nota 'Interculturalisatie van de Zorg' van de Raad voor de Volksgezondheid en de Zorg (RVZ) zijn de ontwikkelingen met betrekking tot de allochtone zorgconsulent (i.e. een verzamelnaam voor intermediaire functies in de zorg. onder andere ook de migrantenvoorlichtster in de eerste lijn) in een stroomversnelling gekomen. De RVZ pleit voor een structurele financiering van de zorgconsulent, en dat is een belangrijke stap in de richting van het erkende beroep van allochtone zorgconsulent. Met de toename van het aantal allochtone zorgconsulenten en de groeiende omvang van de inzet, in méér verschillende settings, over méér onderwerpen blijt het van belang na te gaan onder welke specifieke randvoorwaarden de aansluiting bij de doelgroep optimaal is (Raad voor de Volksgezondheid \& Zorg, 2000). Want in deze ontwikkeling naar een beroep schuilt ook het gevaar de voordelen van het peerschap te verliezen.

\subsubsection{Resultaten van de drie projecten}

In schema B worden de resultaten van de drie projecten samengevat. Voor een deel zijn deze resultaten een empirische onderbouwing voor de uitgangspunten van de vooren-door methode. De resultaten laten zien dat de voor-en-door methode onder randvoorwaarden effectief is. Dat de seksegelijkheid van invloed is op de effectiviteit van de voorlichting is een extra bevestiging van de uitgangspunten van de methode. Want hoe groter de similariteit, hoe groter het effect van de voorlichting. Het is gunstiger om de 
mannen door mannen en de vrouwen door vrouwen te laten voorlichten. Bij de seniorenvoorlichting en de diabetesvoorlichting blijkt dat uit de resultaten; bij de aidsvoorlichting aan Turken en Marokkanen is gemengde voorlichting zelfs geen optie geweest. De resultaten laten echter ook de relativiteit van de 'gelijkheid' zien. De grenzen van gelijkheid zijn niet vastomlijnd. Similariteit is niet hetzelfde is als volledige gelijkheid. De seniorenvoorlichters in dit project behoorden tot de 'jongere' groep onder de ouderen, ze waren relatief hoger opgeleid. Bij de aidsvoorlichting bleek dat de jongeren onder de koffiehuisbezoekers zich minder aangesproken voelden door de aidsvoorlichter. Het is niet duidelijk wat daarvan de oorzaak is. Het kan een gebrekkige aansluiting vanwege de leeftijd zijn, of het kan zijn dat de voorlichter zich vooral richtte op de relatief ouderen. Bij het diabetesproject was de voorlichtster zelf relatief jong en zelf geen diabetespatiënte. Vanuit een theoretisch perspectief is er in de drie besproken projecten sprake van een zwak peerschap. Op het continuüm van professionele voorlichter, via de 'lay health advisor' naar de 'zuivere peervoorlichter', leunen alle drie projecten dicht tegen de professionele voorlichting aan (Vergl. Eng e.a., 1997). Het 'peerschap' kan bij de drie projecten op verschillende manieren worden versterkt. Bij de seniorenvoorlichting kan met de huidige poule van voorlichters de voorlichting seksespecifiek worden georganiseerd, en mannelijke en vrouwelijk seniorenvoorlichters kunnen elkaar afwisselen in gemengde groepen. Ook kan gezocht worden naar manieren om een nog grotere aansluiting te zoeken met de doelgroep door bijvoorbeeld seniorenvoorlichters te trainen uit dezelfde wijk of deelgemeente. Voor de voorlichting over Aids kan méér rekening worden gehouden met de verschillen naar leeftijd door jongere en oudere aidsvoorlichters te trainen. De aidsvoorlichters kunnen op basis van een training mogelijk beter rekening houden met de fase van gedragsverandering van de doelgroep in een bepaald koffiehuis. Het verschil tussen de Turkse en de Marokkaanse mannen in de mate waarin men de voorlichter als een voorbeeld ziet, verdient nader onderzoek. Bij de diabetesvoorlichting kan het peerschap worden versterkt door een Turkse diabetespatiënt(e) te werven als voorlicht(st)er. De migrantenvoorlichtster kan ook seksespecifiek lotgenotencontact organiseren door de diabetespatiënten in groepsbijeenkomsten bij elkaar te brengen. De drie projecten overziend zijn de volgende effectverhogende maatregelen te treffen. De voor-en-door methode zelf kan effectiever worden door bij de selectie en de inzet van de voorlichters méér rekening te houden met geslacht, leeftijd en achtergrond. De voor-en-door methode kan in de context van een effectverhogende strategie worden gebruikt zoals in een community project waarbij ook andere methodes worden toegepast. Dat kan ook betekenen dat met kortere cycli van scholing en uitvoering kan of moet worden gewerkt. Het accent komt dan nog meer op een specifiek peerschap te liggen, zoals bijvoorbeeld een seniorenvoorlichter die in de eigen wijk wordt ingezet voor activerende huisbezoeken. Hoe korter de scholingscycli worden, hoe belangrijker het zal zijn om over een monitorinstrument te beschikken waarmee de uitgevoerde interventieactiviteiten kunnen worden vastgelegd. 


\begin{tabular}{|c|c|c|c|}
\hline Kenmerken & Project 1: & Project 2: & Project 3: \\
\hline Onderwerp & Succesvol ouder worden & Aids & Diabetes \\
\hline $\begin{array}{l}\text { Conclusie } \\
\text { onderzoeks- } \\
\text { vraag effect }\end{array}$ & $\begin{array}{l}\text { Er is een bescheiden } \\
\text { effect aangetoond op } \\
\text { de uitkomstvatiabelen, } \\
\text { met name op sociale } \\
\text { invioed van ouderen, } \\
\text { sociale steun en } \\
\text { subjectieve gezondheids- } \\
\text { beleving. }\end{array}$ & $\begin{array}{l}\text { De voorlichter slaagt erin } \\
\text { kennis over te brengen } \\
\text { en misverstanden te } \\
\text { verminderen, maar niet } \\
\text { om de determinanten voor } \\
\text { gedragsverandering te. } \\
\text { veranderen. }\end{array}$ & $\begin{array}{l}\text { Er is een effect op } \\
\text { vrouwelijke patienten met } \\
\text { verhoogde bloedsuiker- } \\
\text { waarden. En er is op een } \\
\text { aantal determinanten } \\
\text { (voeding, bewegen) een } \\
\text { seksespecifiek en een } \\
\text { leeftijdspecifiek effect bij } \\
\text { de diabetes gerelateerde } \\
\text { Klachten. }\end{array}$ \\
\hline $\begin{array}{l}\text { Conclusie } \\
\text { onderzoeks. } \\
\text { vraag proces }\end{array}$ & $\begin{array}{l}\text { De seniorenvoorlichter } \\
\text { wordt als peer ervaren } \\
\text { door de ouderen. Dat } \\
\text { verschilt niet tussen } \\
\text { mannen en vrouwen, } \\
\text { en er is geen verband } \\
\text { tussen het effect en de } \\
\text { peerervaring. Er is well } \\
\text { een seksespecifiek effect } \\
\text { van de voorlichting: het } \\
\text { effect van de voorlichting } \\
\text { is groter als er sekse- } \\
\text { gelijkheid is (vrouw geeft } \\
\text { voorlichting aan vrouw, } \\
\text { man geeft voorlichting } \\
\text { aan een man). }\end{array}$ & $\begin{array}{l}\text { Aidsvoorlichting voor } \\
\text { migranten is seksespecifiek } \\
\text { georganiseerd, Turkse } \\
\text { en Marokkaanse mannen } \\
\text { verschillen in de mate } \\
\text { waarin ze de aidsvoortichter } \\
\text { als een voorbeeid ervaren. } \\
\text { Er is een samenhang } \\
\text { tussen dat gegeven en de } \\
\text { de mate van openheid van } \\
\text { de voorlichting. De richting } \\
\text { van dat verband is niet } \\
\text { vastgesteid. }\end{array}$ & $\begin{array}{l}\text { De voorlichtster wordt } \\
\text { zowel door mannen als } \\
\text { vrouwen als peer ervaren. } \\
\text { Er is geen relatie met } \\
\text { de grootte van het effect. } \\
\text { Er is zeer vermoedelijk } \\
\text { wel een seksespecifiek } \\
\text { effect: het effect bij } \\
\text { vrouwen is voor een } \\
\text { aantal uitkomstmaten } \\
\text { groter. }\end{array}$ \\
\hline $\begin{array}{l}\text { Aanbeveling } \\
\text { voor de } \\
\text { interventie }\end{array}$ & $\begin{array}{l}\text { Seksespecifiek } \\
\text { organiseren van de } \\
\text { voortichting of de } \\
\text { mannelijke en de } \\
\text { vrouwelijke voorlichters } \\
\text { afwisselen. }\end{array}$ & $\begin{array}{l}\text { Meer rekening houden } \\
\text { met een mogelijk effect } \\
\text { van de leeftujd. }\end{array}$ & $\begin{array}{l}\text { Een etnisch specifieke } \\
\text { diabetespatiënt, of } \\
\text { etnisch en seksespecifiek } \\
\text { lotgenotencontact } \\
\text { organiseren. }\end{array}$ \\
\hline $\begin{array}{l}\text { Aanbevelingen } \\
\text { voor } \\
\text { onderzoek }\end{array}$ & $\begin{array}{l}\text { De vraagstelling over de } \\
\text { subjectieve kenmerken } \\
\text { van de voorlichter beter } \\
\text { operationaliseren. }\end{array}$ & $\begin{array}{l}\text { Het determinantenmodel } \\
\text { van condoomgebruik voor } \\
\text { de jongeren verder } \\
\text { uitwerken. } \\
\text { De vraagstelling over de } \\
\text { subjectieve kenmerken van } \\
\text { de voorlichter beter opatio- } \\
\text { naliseren }\end{array}$ & $\begin{array}{l}\text { Voor de mannen is nog } \\
\text { onduidelijk of ze } \\
\text { voldoende } \\
\text { via de peermethode } \\
\text { kunnen worden bereikt, } \\
\text { en of het versterken } \\
\text { van lotgenotencontact } \\
\text { de beste weg is. } \\
\text { Het is ook denkbaar dat } \\
\text { de huisarts met behulp } \\
\text { van een tolk een betere } \\
\text { oplossing is. }\end{array}$ \\
\hline
\end{tabular}

\subsection{Implicaties voor onderzoek}

In de drie besproken projecten rond de voor-en-door methode komt een aantal thema's terug die hieronder los van de concrete projecten zullen worden besproken. Het eerste thema betreft de vraag hoe het peerschap kan worden vastgesteld. Het gaat daarbij om het vaststellen van de similariteit van de peervoorlichter (voorbeeldfunctie, wijgevoel bij de doelgroep), en de vraag of dat aspect van het peerschap een relatie heeft met effectiviteit. Het tweede thema betreft de pretentie van peerprojecten dat de participatie door de peervoorlichter aan de voorlichtingsprojecten voor hem of haar zélf ook voor- 
delig is. En de vraag is of dat op gespannen voet staat met de effectiviteit van projecten. Het derde thema betreft de vraag hoe effectevaluatieonderzoek van peerprojecten het beste kan worden opgezet. Is het voldoende om effectiviteit aan te tonen, of moet ook de toegevoegde waarde worden aangetoond? Het vierde en laatste thema betreft de positie van de onderzoeker en de interventieontwikkelaar. In de drie besproken projecten zijn onderzoek en interventie nauw op elkaar betrokken. Is dat een bedreiging voor de validiteit, of creëert dat condities voor een optimale afstemming tussen onderzoek en interventie?

\subsubsection{Objectief en subjectief peerschap}

Bij de resultaten van de drie projecten valt op dat de subjectieve beoordeling door de respondenten van het peerschap minder in verband gebracht kon worden met de effectiviteit van de voorlichting dan de objectieve overeenkomsten tussen de deelnemer en de voorlichter. Bij de seniorenvoorlichting was de seksegelijkheid (Mannen lichten mannen voor, vrouwen lichten vrouwen voor) een effect modificator maar de rol van de voorlichter zoals beoordeeld door de deelnemers aan de voorlichting, deed er niet veel toe. Bij de diabetesvoorlichting is de vraagstelling met betrekking tot de subjectieve beoordeling van de voorlichtster zodanig geweest dat er geen onderscheid gemaakt kon worden: alle respondenten (mannen én vrouwen) scoorden zeer positief op alle rolvariabelen. Er is echter wel een seksespecifiek effect, en er is een aanwijzing dat er een leeftijdspecifiek effect is: de jongere vrouwen lijken meer profijt te hebben van de voorlichting van een relatief jonge voorlichtster dat de oudere vrouwen. Bij de aidsvoorlichting lijkt er wel een verschil te zijn met betrekking tot de mate waarin men de voorlichter als een voorbeeld ervoer, en daarbij is waarschijnlijk sprake van een samenhang met het gedrag van de voorlichter. Als operationalisatie van het peerschap zijn de objectieve kenmerken van de voorlichter (sekse, leeftijd) belangrijker geweest dan de subjectieve beoordelingen door de deelnemers aan de voorlichting (Vindt de deelnemer aan de voorlichting de voorlichter een voorbeeld?). De belangrijkste reden is vermoedelijk dat de operationalisatie niet voldeed. In hoeverre de voorlichter een voorbeeld is geweest voor de deelnemers aan de voorlichting is niet eenvoudig met één vraag vast te stellen. Bij de diabetesvoorlichting speelt sociale wenselijkheid van de antwoorden waarschijnlijk een rol. Deze respondenten wilden op de eerste plaats benadrukken dat ze de voorlichting in de eigen taal en de persoonlijke begeleiding positief beoordeelden. Bij de aidsvoorlichting heeft sociale wenselijkheid mogelijk minder gespeeld, maar daarbij gold de beperking dat er zo weinig ruimte was voor vragen over de voorlichter. Sociale wenselijkheid speelde vermoedelijk ook een rol bij de seniorenvoorlichting. Er is een drempel om zeer kritisch te zijn over de voorlichter/ster. Je moet ten slotte een oordeel uitbrengen over een persoon die net de rol van voorlichter heeft gehad. Vermoedelijk zou de voorlichting heel slecht moeten lopen, voordat een respondent in het geval van peer voorlichting zeer negatief over een voorlichter kan zijn. Aan de andere kant is er óók een drempel om die persoon 'als een voorbeeld voor jezelf' te bestempelen. leder individu is ten slotte op de eerste plaats uniek.

Geconcludeerd kan worden dat er meer aandacht nodig is voor de operationalisatie van 
deze procesvariabelen. Er is een aantal dimensies aan de rol van de voorlichter die op basis van de theorie in een operationalisatie zouden moeten worden uitgewerkt. Dat is het aspect van het wijgevoel. De voorlichter is 'één met de doelgroep'. Daarnaast is er het rolmodel: de voorlichter moet nastrevenswaardig zijn. En in die zin moet hij boven de doelgroep uitstijgen. Dit zijn enigszins tegenstrijdige elementen aan hetzelfde concept waardoor een geldige operationalisatie lastig zal zijn. Ook als het lukt een goed beeld te verkrijgen van de mate waarin de respondent similariteit ervaart met de voorlichter, is nog niet zeker of er een relatie met effect aangetoond kan worden. Het zou kunnen dat de 'vicarious experience' van Bandura (1986) ('De voorlichter laat een bepaald gedrag zien of motiveert tot dat gedrag, ik ben of zou willen zijn zoals hij is, dus ik zal ook willen en kunnen wat hij zegt!) vooral onbewust zijn werk doet. Dat zou ook verklaren waarom in de besproken projecten vooral de objectieve kenmerken (sekse, leeftijd, etniciteit) van similariteit vaker samenhangen met de effectiviteit van de interventie dan de subjectieve beoordeling van de voorlichter.

\subsubsection{Emancipatorisch effect}

De pretentie van de peer methode is dat meedoen in een peertraject voor de peer zelf voordelig is (Gelauff-Hanson e.a., 1999; Penninx \& Prinsen, 2000). Het werken als een peer voorlichter kan een emancipatorisch effect hebben bijvoorbeeld omdat ouderen als seniorenvoorlichters bewust worden van hun positie in de samenleving. Het werken als een peer kan het zelfbeeld versterken, bijvoorbeeld van een homoseksuele man die als peer voorlichter veel explicieter als homoseksuele man paar buiten treedt. Het werk kan een belangrijke stap in een loopbaan betekenen zoals dat zeker voor een aantal migrantenvoorlichtsters geldt (Zie ook: Pelt, 1998; Ouwehand e.a., 1998; Verrept, 1995). Er zijn juist bij de migrantenvoorlichtsters voorbeeiden van fantastische ontwikkelingen omdat bij hen vaak sprake was van 'onder-educatie'. De voorlichtsters zijn vaak capabele intelligente vrouwen die nooit de kans hebben gehad op onderwijs op hun niveau. en via de kadercursus grijpen ze die kans. Van een vrouw met alleen basisschool (en soms die niet afgemaakt!) kan een voorlichtster via de kadercursus naar MBO en zelfs HBO maatschappelijk werk doorstromen. En paradoxaal genoeg is dan - gelukkig niet altijd! - de laatste emancipatiestap dat men algemeen inzetbaar wil zijn voor alle doelgroepen. Men wil juist niet meer worden aangesproken op de eigen etnische identiteit. Er zijn echter ook aanwijzingen voor een tegenovergesteld effect, of in ieder geval voor stagnatie in ontwikkeling. Er kunnen situaties ontstaan waarbij de druk vanuit de organisatie om de doelgroep te bereiken erg groot wordt. De eisen die dan aan het individu gesteld worden kunnen te zwaar zijn. Dat kan stress veroorzaken.

Dit totaal van positieve en negatieve 'bijeffecten' is nog nooit goed vastgesteld. Dwars door alle peervormen heen (migrantenmannen, migrantenvrouwen, seniorenvoorlichters) zou het interessant zijn om deze persoonlijke ontwikkelingen in kaart te brengen om na te gaan wat daarbij stimulerende en remmende factoren zijn geweest. Een korte rondgang langs de Rotterdamse migrantenvoorlichtsters leverde het volgende beeld op. In de eerste opleiding zijn 12 voorlichtsters opgeleid en daarvan zijn er vijf vrouwen doorgestroomd naar andere functies. Vier van deze vijf vrouwen hebben een reguliere 
Hbo-opleiding afgerond, en zijn ook buiten de GGD gaan werken. De tweede lichting bestond uit 20 vrouwen. Daarvan zijn acht vrouwen doorgestroomd naar andere functies, en vijf werken als allochtone zorgconsulent. Ook uit deze groep heeft een aantal een Hbo-opleiding gevolgd. De groep van de derde opleiding bestong uit 12 vrouwen, en daarvan zijn er vier doorgestroomd naar ander werk (Denktaş, 2002). De voorlopige conclusie is dat een aanzienlijk deel van de voorlichtsters een andere, meestal hogere functie vervult. Tegelijkertijd wordt benadrukt dat de organisatorische randvoorwaarden voor de inzet van de voorlichtsters nauwgezet in de gaten moet worden gehouden.

Volgens de onderzoekster moet de GGD meer aandacht schenken aan de waardering voor de voorlichtsters, zowel in materiële zin (de betaling) als in immateriële zin (werkplek, begeleiding, etc.). Dat zal gemakkelijker zijn als VWS het advies van de RVZ doorvoert en er een structurele financiering en inbedding voor de allochtone zorgconsulenten wordt gevonden (RVZ, 2000). Daarmee is dan een nieuw beroep in de zorg ontstaan. Het is van belang dat de inzet van de zorgconsulent met evaluatieonderzoek wordt begeleid om de kwaliteit van de interventies te bewaken. Is met dit nieuwe beroep de emancipatie voltooid? In ieder geval zal het veel voorlichtsters veel loopbaankansen bieden. En al die zorgconsulenten kunnen een bijdrage leveren aan de emancipatie van de etnische minderheden.

Voor alle peer voorlichters, dus ook voor de peervoorlichters voor wie een formele loopbaan als voorlichter minder relevant is zoals bij de seniorenvoorlichters en de mannelijk migrantenvoorlichters, is het van belang meer inzicht te krijgen in de taakopvatting en de rolopvatting van de peervoorlichters, en de relatie met effectiviteit van de voorlichting. Voor de jonge homomannen is het van belang te weten wat het werk als peer voorlichter betekent voor hun eigen identiteit (Wagemans e.a., 1998). De taakopvatting van de peervoorlichter, hun persoonlijke karakter, de verwachting van de doelgroep, het zijn allemaal factoren die consequenties hebben voor de manier van ondersteuning. Een 'zuiver' peermodel is door een formele organisatie waarschijnlijk moeilijk te ondersteunen maar er zijn tussenvormen die nog niet zijn uitgeprobeerd. Denk daarbij aan snelle en korte cycli van scholing waarbij het sociale netwerk van de peer een belangrijk selectiecriterium is. Mogelijk zijn er nog andere doelgroepen waarbij een vorm van peer voorlichting de meest effectieve manier is om de doelgroep te bereiken. In België bij Kind en Gezin loopt een interessant project met zogenaamde ervaringsdeskundigen die worden ingeschakeld bij de begeleiding van kansarme moeders. Het gaat daarbij om de ervaring met de armoede, en met opgegroeid zijn in armoede, en de specifieke gevoeligheid die dan noodzakelijk is om een wijgevoel te creëren. Alleen de ervaringsdeskundige was in staat om bij het kind door het schuldgevoel over de armoede heen te breken, om te 'ontschuldigen' zoals men het op een studiedag in Rotterdam noemde (Zie Kind en Gezin, 2002).

\subsubsection{Effectiviteit en toegevoegde waarde.}

Rootman e.a. (2001) schetsen in hun inleiding voor de omvangrijke WHO-studie over de planning en evaluatie van gezondheidsbevordering een raamwerk waarin de belangrijkste vragen rond evaluatie van gezondheidsbevordering worden geplaatst. Een van 
de discussies betreft de kwantitatieve versus kwalitatieve methodologie van evaluatieonderzoek. Ze delen evaluatie-onderzoekers in drie posities in: het positivistisch standpunt, het constructivistisch standpunt, en op een middenpositie het kritisch multiplisme. Vanuit het positivistisch standpunt wordt de werkelijkheid op een neutrale objectieve manier bezien, en oorzaak en gevolg kunnen overtuigend worden aangetoond. De beste methode om dat te doen is het experiment. Tegenover het positivisme staat het constructivisme, waarbij ervan wordt uitgegaan dat kennis beperkt geldig is, en in interactie geconstrueerd wordt door de waarnemer. De evaluatieonderzoeker is één van de actoren in het proces, en kan een belangrijke bijdrage leveren aan verbeteringen in het programma. Het is meestal erg moeilijk resultaten te generaliseren naar andere programma's of contexten, juist omdat het unieke sterk benadrukt wordt. Het kritisch multiplisme neemt een middenpositie in. De methode van evaluatieonderzoek die wordt gekozen hangt af van de vraag die wordt gesteld. Deze evaluatieonderzoekers zijn methodologisch eclectisch, en passen hun methodes aan de eisen van de besluitvormers en/ of praktijkwerkers aan. (Rootman e.a., 2001). Rootman e.a. komen tot een raamwerk voor de evaluatie van gezondheidsbevordering waarbij veel ruimte wordt gelaten voor veel verschillende benaderingen, getuige ook de omschrijving van evaluatie. Evaluatie omschrijven zij als het systematisch onderzoeken en vaststellen van eigenschappen van een programma of interventie met het doel kennis te vergaren, bruikbaar voor verschillende belanghebbenden en voor een verscheidenheid aan doeleinden. Omdat de meeste programma's voor gezondheidsbevordering moeten worden uitgevoerd in een 'open systeem' waarin weinig controle mogelijk is, is volgens Rootman e.a. juist het positivistisch standpunt nauwelijks houdbaar. De onderzoeken die hierboven zijn gepresenteerd, zijn vanuit een positivistisch standpunt uitgevoerd, met veel aanpassingen aan de eisen van de praktijk. Nergens kon een 'zuiver' experiment worden uitgevoerd. De belangrijkste reden dat in deze drie projecten wél vanuit deze meer traditionele methodologie kon worden gewerkt, heeft te maken met de beheersbaarheid van de experimentele factor. Voor alle drie projecten geldt dat de 'experimentele factor' relatief goed onder controle stond. Waar dat niet het geval is, zoals in grootschaliger interventies, bijvoorbeeld bij wijkgerichte projecten, is een evaluatie vanuit een constructivistisch standpunt zinvoller omdat het meer mogelijkheden biedt voor terugkoppeling naar meerdere belanghebbenden (Voorham, De Haes \& Mackenbach, 2002). Voor vervolgonderzoek blijt het van belang dat de effectiviteit van de peer methodes wordt aangetoond, zoals ook wordt geadviseerd door de Commissie Albeda (Programmacommissie SEGV-2, 2001). De peer methode is veelbelovend maar de effectiviteit moet steviger worden aangetoond. Nadat de effectiviteit is aangetoond speelt ook dat de effectiviteit bij voorkeur aangetoond wordt in vergelijking tot andere, meer traditionele methodes. Dus de vraagstelling is dan wat de mérwaarde is van de peermethode. Dat levert met peer voorlichting de moeilijk te beantwoorden vraag wat de traditionele methode is? De seniorenvoorlichting is ontstaan door de grote vraag aan uitvoerende voorlichtingsbijeenkomsten die door een gvo-medewerker werden verzorgd. De seniorenvoorlichters (de peervoorlichters) zijn een alternatief voor de gvo-medewerker (de expert voorlichting), maar dan wel met een veel grotere capaciteit en dus met 
een groter bereik. Bij de migrantenvoorlichtsters zijn er wel alternatieve modellen. Een idee zou zijn een vergelijking te maken tussen twee peer modellen, bijvoorbeeld het vergelijken van buurtmoeders en migrantenvoorlichters. Of de vergelijking van een diabetes lotgenoot (een Turkse diabetespatiënt) en de Turkse migrantenvoorlichtster. Het grote voordeel van het vergelijken van twee methodes is het relatieve gemak waarmee een experiment kan worden uitgevoerd. Het aselect toewijzen aan twee verschillende interventies om na te gaan welke beter werkt, zal relatief gemakkelijker te organiseren zijn dan een controlegroep die 'niets' krijgt. In deze relatief controleerbare situaties waarbij het optreden van de peervoorlichter in groepen of met patiënten wordt onderzocht, zijn in de praktijk experimenten denkbaar waarmee de effectiviteit van de peer methode overtuigend kan worden aangetoond. Martijn e.a. (2003) rapporteren over een studie in een asielzoekerscentrum waarbij de inzet van de peer voorlichter (de lay health advisor') wordt vergeleken met een professionele voorlichter (arts of verpleegkundige). Voor beide programma's worden positieve effecten aangetoond op attitude en kennis maar de peer voorlichter blijkt effectiever in het bereiken van de verandering van intenties. Daarmee wordt de sterke kant van de peer methode bevestigd. Ingewikkelder wordt het onderzoek als de peer methode in de bredere effectverhogende context van de community interventie moet worden onderzocht. Het is theoretisch aannemelijk dat juist in de context van de community interventie de peer methode effectiever wordt, en juist dan wordt de onderzoekbaarheid met harde eindtermen minder gemakkelijk. Op dit moment wordt een community interventie voor Rotterdamse Antillianen en Arubanen geëvalueerd waarbij de peer methode een belangrijk onderdeel is, naast de inzet van lokale massamedia, training van middenkader, en inzet bij manifestaties. Bij deze community interventie (Amor i Salu ofwel Liefde \& Gezondheid) is een vóór - en een námeting, maar er is géén controlegroep. Wat zou een controlesituatie kunnen zijn? De Antilliaanse gemeenschap in Amsterdam of Den Haag? In de discussies over de subsidieaanvraag achtte men de kans op contaminatie zeer groot. Mogelijk kan er een dosis -respons relatie worden aangetoond, door een relatie aan te tonen tussen de expositie aan campagneactiviteiten en het effect. Een dosis -respons relatie is ook een belangrijke voorwaarde om causaliteit te kunnen vaststellen.

\subsubsection{Afstemming van interventie en evaluatieonderzoek}

Planmatigheid creëert effectiviteitl Dat betekent ook dat de inzet van evaluatieonderzoek op een juiste manier op zichzelf de effectiviteit zal kunnen bevorderen. Bij de drie besproken projecten is er relatief veel aandacht voor de tuning van onderzoek en interventie, voor de afstemming van evaluatiepunten en leer - en veranderdoelen. Daarbij is sprake van een trapsgewijze ontwikkeling van de interventie en het onderzoek. Dat vereist een nauwe samenwerking van onderzoekers en interventiemedewerkers (Vergl. Kok \& Green, 1990). In de drie besproken projecten zijn het onderzoek en de interventie in dezelfde organisatie ontwikkeld, zelfs onder de begeleiding van één projectleider.

Is dat een gevaar voor objectiviteit? Zal er niet een impliciete druk worden uitgeoefend op de onderzoeker om effect aan te tonen? Is de objectiviteit van onderzoek in het geding als dezelfde organisatie het onderzoek en de interventie doet? Met een juiste 
organisatorische inbedding maakt het niet uit waar de onderzoeker zit. De relatieve onafhankelijkheid van de onderzoeker kan goed worden gewaarborgd door een aparte begeleidingsgroep voor het onderzoek in te stellen. Het is wel van belang dat er een projectleider is die zich verantwoordelijk voelt voor zowel de kwaliteit van de interventie als voor de kwaliteit van het onderzoek. Waar de onderzoeker ook zit, er zijn twee kwetsbare fases die een projectleider in goede banen moet leiden. De eerste is de fase van de ontwikkeling, waarbij de leer - en veranderdoelen van de interventie, in precieze afstemming met de uitkomstmaten van de evaluatie moeten worden geformuleerd. De evaluatieonderzoeker moet daarbij geen afwachtende buitenstaander zijn maar juist een lastige vragensteller die de preventiemedewerker moet dwingen tot keuzes over de leer en veranderdoelen. De interventieontwikkelaar moet de onderzoeker bij de les houden omdat het vaak gemakkelijk is op basis van de eerste algemeen geformuleerde doelstellingen en het reeds uitgevoerde epidemiologische onderzoek een voorzet voor de uitkomstmaten te doen zonder dat er is nagedacht over de concrete interventie. Er is vaak een discussie nodig over de bruikbaarheid van gevalideerde bestaande meetinstrumenten, die veelal niet ontwikkeld zijn om veranderingen vast te stellen bij de concrete leer en veranderdoelen van de interventie. Aansluiten bij de bestaande instrumenten vergroot de relevantie en de vergelijkbaarheid van de interventie maar het vergroot ook de kans dat leer - en veranderdoelen en de uitkomstmaten langs elkaar heen schieten. Dat kan bij een interventie met relatief weinig impact per voorlichter/doelgroep contact zoals de eenmalige koffiehuisvoorlichtingen over aids, waarbij bovendien maar een klein aantal vragen kon worden gesteld (de quiz), heel gemakkelijk gebeuren. De tweede kwetsbare fase is de rapportagefase waarbij de onafhankelijkheid van de onderzoeker moet worden gewaarborgd, maar waarbij de interactie met de interventiemedewerkers onmisbaar is. Alleen dan ontstaan de relevante interpretaties van de resultaten en kunnen er relevante en haalbare aanbevelingen worden gedaan. Voor de interpretatie van de resultaten is het noodzakelijk dat in evaluatieonderzoek behalve de uitkomstmaten, ook een monitoring van de interventies plaatsvindt om te kunnen vaststellen dat de interventies hebben plaatsgevonden zoals bedoeld. Of met andere woorden, of de interventietheorie steeds juist is toegepast. In de drie besproken projecten is er veel aandacht geweest voor de rol van de voorlichter zoals ervaren door de deelnemers. Er kon daarom niet worden vastgesteld of bijvoorbeeld de mannelijke seniorenvoorlichters zich in de cursus anders hebben gedragen dan de vrouwelijke seniorenvoorlichters. Voor de juiste interpretatie van de resultaten is de 'black box' van de interventie liefst zo klein mogelijk.

\subsection{Afsluiting: Diversiteit in gezondheidsbevordering}

McPherson wijst erop dat binnen de meeste westerse samenlevingen etniciteit de belangrijkste scheidslijn tussen mensen vormt, gevolgd door geslacht, leeftijd, religie en opleiding (McPherson e.a., 2001). In Rotterdam zijn etniciteit, geslacht en leeftijd ook de lijnen waarlangs de voor-en-door methode is ontwikkeld. Het evaluatieonderzoek laat zien dat deze methode onder voorwaarden effectief is. Daarnaast wordt een groter effect aangetoond als binnen de methode nóg een voor-en-door aspect wordt geres- 
pecteerd. De aids-voorlichting is etnisch en seksespecifiek georganiseerd, en in het evaluatieonderzoek wordt een leeftijdspecifiek effect aangetoond. De seniorenvoorlichting is etnisch en leeftijdsspecifiek georganiseerd, en er wordt in het evaluatieonderzoek een seksespecifiek effect aangetoond. De diabetesvoorlichting is etnisch specifiek georganiseerd, en er is een seksespecifiek en leeftijdspecifiek effect aangetoond. Dit totaal is een sterk pleidooi voor diversiteit in gezondheidsbevordering. Hoe groter de similariteit is, hoe groter de effectiviteit lijkt te zijn. Maar dat geldt tot een bepaalde grens: de ouderen onder de ouderen lieten zich juist wel aanspreken door de relatief jongeren. Waar dit omslagpunt ligt, is nog niet in duidelijke regels te vatten. Zolang er sprake is van een verbetering in het rolmodel met de mogelijkheid van een opwaartse vergelijking, zal het peerschap sterker kunnen zijn. Vermoedelijk wordt de grens aan de diversiteit eerder bereikt door de praktische beperkingen. Een aparte peer voorlichter voor elke denkbare subgroep in de doelgroep kan de methode onwerkbaar maken. Bovendien zijn er nog vele andere factoren die de effectiviteit kan bevorderen. Er is in de besproken projecten alleen gelet op een aantal kenmerken van de voorlichter en de rol van de voorlichter. Achter de vraag of de peervoorlichter seksespecifiek moet zijn, ligt de vraag of er in het gehele planningsproces van gezondheidsprobleem naar een interventie voldoende aandacht is voor seksespecifieke kenmerken. (Vergl.

Wagemakers ea, 2001). Problemen met de gezondheid zijn vaak seksespecifiek. Daarover is geen discussie. In epidemiologisch onderzoek is er vrijwel altijd aandacht voor verschillen in het voorkomen en het verklaren van gezondheidsklachten die samenhangen met geslacht. Van het individu wordt in onze samenleving het geslacht zo ongeveer als eerste in registraties vastgelegd. Vanuit het oogpunt van gezondheidsbevordering zijn de verschillen interessant in zoverre het vermijdbare verschillen betreft. Daarover is nog veel discussie, en er is verder onderzoek noodzakelijk (Gijsbers van Wijk \& Kok, 1997; Lagro-Janssen \& Noordenbos, 1997; Oosten e.a., 2000; ZonMw, 2000). Als het gedrag één van de determinanten van het gezondheidsprobleem is, dan is de vraag of de gedragsmodellen die in de determinantenstudies gebruikt worden voldoende specifiek worden toegepast. Hoe vaak komt het niet voor dat in een determinantenmodel een interactie wordt aangetoond met sekse? Lien e.a. (2002) concluderen bij een toepassing van de theorie voor beredeneerd gedrag dat de grote sekseverschillen in de sterkte van de relaties in het model consequenties moet hebben voor de interventiemethodes en de boodschap. Ratner e.a. (1994) gaan een stap verder en concluderen dat 'researchers of health promotion should not assume that the causal mechanisms underlying health promotion behaviours in men and women are identical, but must forge ahead with an exploration and clarification of the possible differences:. In zijn inaugurele rede wijst De Vries (2000) op de lacune in determinantenstudies die te weinig rekening houden met gewoontevorming en de rol van het gevoel bij gezondheidsgedrag. Het is aannemelijk dat juist daarin ook de sekseverschillen zichtbaar zullen zijn. Diezelfde vragen kunnen gesteld worden over etnisch specifieke gezondheidsbevordering. Wordt er voldoende rekening gehouden met de etnische verschillen? De Turkse en Marokkaanse voorlicht(st)ers begrijpen de 'Nederlandse voorlichting' vaak niet, die te veel uitgaat van mensen die beredeneerde keuzes maken. Ze hebben de 
neiging om directiever te zijn in hun adviezen. Of zoals bij de diabetesvoorlichting waarbij het lijkt dat enkele patiënten hun gedrag niet veranderen omdat ze begrijpen hoe het diabetesdieet werkt en daardoor gemotiveerd worden, maar ze veranderen hun gedrag omdat de voorlichtster het vraagt. Ze veranderen hun gedrag omdat ze de voorlichtster vertrouwen, In het 'elaboration likelihood model' wijzen Petty en Cacioppo (1986) al op het verschil in de manier waarop mensen informatie over gezondheid kunnen verwerken. Meestal is dat, net als nu, een verklaring achteraf. Kan ook vóóraf bij de interventieontwikkeling met deze verschillen méér rekening worden gehouden? Bij de planning van de Aidsvoorlichting voor Turken en Marokkanen was het van het begin af aan duidelijk dat die voorlichting behalve etnisch specifiek ook seksespecifiek georganiseerd zou moeten worden. Die gemengde voorlichtingssituatie over Aids was op dat moment ondenkbaar en onuitvoerbaar. $\mathrm{Bij}$ de seniorenvoorlichting en de diabetesvoorlichting is seksespecificiteit geen vraag geweest in de planning. Achteraf is dat jammer. Wagemaker e.a. (2001) gaan ervan uit dat de communicatiestijlen tussen mannen en vrouwen behoorlijk verschillen. Mannen neigen meer naar een diagnose/recept benadering in een zender/ ontvanger perspectief, en vrouwen zijn minder instrumenteel en zien graag interactieve benaderingen. In de planning van interventies kan meer rekening met dit verschil worden gehouden, en moet met meer lef seksespecifieke interventies worden ontwikkeld. In het diabetesproject was het mogelijk voor de mannen passender geweest als ze door de huisarts (met een tolk) benaderd waren. In de ontwikkeling van de interventies is er een drempel te overwinnen om zulke grote verschillen tussen de benadering van mannen en vrouwen toe te laten. Het zou goed zijn als de voor-en-door methode in het algemeen, en in het bijzonder de seksespecifieke interventieontwikkeling in het Preventie Effectmanagement Instrument (Preffi 2.0) meer aandacht zou krijgen (Molleman e.a., 2003; Peters e.a., 2003). Los van de instrumentele vraag over de effectiviteit speelt de normatieve vraag over wat mag en wat behoort te zijn. Hoe etnisch en seksespecifiek gezondheidsinterventies bij de GGD van Rotterdam e.o. mogen zijn, is recent onderwerp van politiek debat geworden. Daarbij is van belang dat de effectiviteit van de interventies een belangrijk argument blijt. Als het gaat om het stimuleren van diversiteit in de zorg dan heeft de Rijksoverheid al een eerste stap gezet met de instelling van de Landelijke Expertcommissie Sekse en Etniciteit in de Gezondheidszorg die de aanbevelingen van de Nota 'Met zorg kiezen' langs de sekse en etnisch specifieke lijnen wil uitwerken (Ministerie van VWS, 2001). Of zoals het in de voorbereidende expertmeeting 'Naar een seksespecifiek en multicultureel patiënten/ consumentenbeleid' ( 6 november 2001) werd gesteld: 'De sekse van de patiënt en diens etnische en culturele identiteit zijn tezamen zó bepalend voor zijn of haar zorgvraag, dat het eigenlijk niet eens beïnvloedende factoren zijn maar beslissende factoren. Scherp gesteld: sekse en etniciteit maken de vraag, ze vormen de behoefte' (Landelijke Expertcommissie Sekse en Etniciteit in de Gezondheidszorg, 2002). Dat geldt des te sterker voor gezondheidsvoorlichting! 


\section{Literatuur}

Bandura A. (1986). Social foundations of thought and action; a social cognitive theory. Engel-wood Cliffs NJ: Prentice Hall.

Bartholomew LK, Parcel GS, Kok G, Gottlieb NH. (2001). Intervention Mapping: designing theory and evidence-based health promotion programs. Mayfield Publishing Company, Mountain View, California.

Bruijnzeels, M.A., de Hoop T., Voorham A.J.J. (1998). Migrantenvoorlichting in de huisartsenpraktijk in Rotterdam Zuid; een evaluatieverslag van de pilotfase, GGD Rotterdam e.o.

Denktas S. (2002). Allochtonen in dienst van de GGD. In: Instituut voor SociologischEconomisch Onderzoek \& Centrum voor Onderzoek en Statistiek van de Gemeente Rotterdam (2002) Minderhedenmonitor 2001. Etnische minderheden in Rotterdam. Rotterdam: ISEO \& COS, p. 156

Eng, E., Parker, E., Harlan, C. (1997). Lay health advisors intervention strategies: a continuum from nature helping to paraprofessional helping. Health Education \& Behaviour 24. 413-417.

Gelauff-Hanzon, C., Keune, C., Tan, S. (1999). Paraprofessionals: pioniers of pionnen? Een onderzoek naar de voorwaarden van een optimale inzet. Verwey-Jonker Instituut, Utrecht.

Gemeente Rotterdam (2001). Ouderenbeleid 2002-2004: Actief, Kleurrijk en Zorgzaam. Gemeente Rotterdam.

GGD Rotterdam (2000). Promotion of social participation and prevention of loneliness among Ridderkerk older adults In samenspraak. Projectvoorstel in het kader van het Programma Preventie van ZonMw. GGD Rotterdam

Gijsbers van Wijk, C.M.T. van, Kok A.M. (1997) Sekseverschillen in gezondheidsbeleving. Nederlands Tijdschrift voor Geneeskunde. 141 p. 283-7

Groot, R de. (1990) Succesvol ouder worden, kansen en bedreigingen. Tijdschrift voor de Sociale Sector; 10:31-33.

Kind en Gezin: www.kindengezin.belpzlervaring.html.

Kok G., Green L.W. (1990) Research to support health promotion in practice: a plea for increases co-operation. Health Promotion International, 5,4: 303-8

Kocken P.L. (2000) Health promotion in migrants and older adults. Epidemiological diagnosis, intervention development and effect evaluation. Proefschrift Maastricht.

Kocken P.L., Wouter L., Voorham A.J.J., de Zwart O. (2003). Amor i Salú. Het Rotterdamse communityproject ter bevordering van de seksuele gezondheid van Antillianen en Arubanen. GGD Rotterdam e.o.

Kocken P.L., Voorham A.J.J. , Brandsma J., Swart W.A.J.M. (2001) Effects of peer-led Aids 
education aimed at Turkish and Moroccan male migrants in the Netherlands: a randomized controlled evaluation study. European Journal of Public health; 11, 2: 153-159.

Kocken, P.L., Voorham, A.J.J. (1998). Effects of a peer-led senior health education program. Patient Education and Counselling: 34, 16-23.

Kroesen, M., Allochtone zorgconsulent: een brug tussen zorgverlener en patiënt; eindrapportage van het project Allochtone Zorgconsulenten. PP /CP Utrecht en Schakels, Utrecht 1998.

Lagro-Janssen, T. en G. Noordenbos (red.). Sekseverschillen in ziekte en gezondheid. SUN, Nijmegen, 1997

Landelijke expertcommissie Sekse en Etniciteit in de Gezondheidszorg (2002). Patiēntenl Consumentenbeleid langs sekse en etnisch specifieke lijnen. Advies 1. Den Haag: Min. voor WWS: p. 20.

Lien N., Lytle L.A., Komro K.A. (2002). Applying Theory of Planned Behavior to Fruit en Vegetable Consumption of Young Adolescents. Am J Health Promot. 16, 4: 189-197

Martijn C., de Vries N.K., Voorham A.J.J., Brandsma J., Meijs M., Hospers H.J. (2003) The effects of Aids prevention programs by lay health advisors for migrants in the Netherlands. (Accepted by Patient Education and Counseling)

McPherson M., Smith-Lovin L., Cook J.M. (2001). Birds of a feather: Homophily in Social networks. Annu. Rev. Sociol., 27: 415-44.

Ministerie van Volksgezondheid, Welzijn en Sport (2001). Met zorg kiezen. De toerusting van patiënten en consumenten in een vraaggestuurde zorg. Den Haag: Ministerie van VWS.

Molleman G., Peters L., Hommels L., Ploeg M. (2003) Preventie effectmanagement Instrument Preffi 2.0 Scoreboek. Nederlands Instituut voor Gezondheidsbevordering en Ziektepreventie (NIGZ): Woerden

NIGZ (Nederlands Instituut voor Gezondheidsbevordering en Ziektepreventie) (1998) Tien jaar voorlichting in de eigen taal en cultuur over gezondheid en opvoeding. Woerden: NIGZ.

Oosten, N. van, Kok E. , Bavel M. van (2000). Dronken mannen, depressieve vrouwen I? Feiten en cijfers over het verband tussen sekse en geestelijke gezondheid. TransAct, Utrecht.

Ouwehand, W., (1998). Brugwerkers, migrantenvoorlichtster en migrantengastvrouw; evaluatie vanuit drie perspectieven: patiënt, zorgverlener en brugwerker, GGD Den Haag.

Petty R.E., Cacioppo J.T. (1986) Communication and Persuation. Central and Peripheral Routes to Attitude Change. New York, Springer Verlag 
Peit W. (1998) Paraprofessionals een stap verder. Functieontwikkeling van intermediairs. Averroes Stichting, Forum, NIGZ. Amsterdam, Utrecht, Woerden

Peters L., Molleman G., Hommels M., Ploeg M., Hosman C., Jané-Llopis E. (2003) Preventie Effectmanagement Instrument Preffi 2.0 Toelichting. Nederlands Instituut voor Gezondheidsbevordering en Ziektepreventie (NIGZ): Woerden

Programmacommissie Sociaal-Economische Gezondheidsverschillen-tweede fase (2001) Sociaal-economische gezondheidsverschillen verkleinen. Eindrapportage en beleidsaanbevelingen van de Programmacommissie SEGV-2. Den haag: ZonMw. p. 45-6

Penninx, K., Prinsen, B. (2000). De voor en door methode. Burgers als helpers en voorlichters. NIZW. Utrecht.

Raad voor de Volkgezondheid \& Zorg. (2000). Interculturalisatie van de gezondheidszorg. Advies aan de Minister van Volksgezondheid, Welzijn en Sport. Zoetermeer RVZ.

Ratner P.A., Bottorff J.L., Johnson J.L., Hayduk L.A. (1994). The Interaction Effects of Gender within the Health Promotion Model. Research in Nursing and Health, 17, 341-350

Rootman I., Goodstadt M., Hyndman B., McQueen D.V., Potvin L., Springett J., Ziglio E. (ed.) (2001) Evaluation in Health Promotion. Principles and Perspectives. WHO Regional Publications European Series no. 92.

Rootman I., Goodstadt M., Potvin L., Springett J. (2001) A framework for health promotion evaluation. In: Rootman I., Goodstadt M., Hyndman B., McQueen D. V., Potvin L., Springett J., Ziglio E. (ed.) (2001) Evaluation in Health Promotion. Principles and Perspectives. WHO Regional Publications European Series no, 92., 7-41

Uitewaal P.J.M., Voorham A.J.J., Bruijnzeels M., Berghout A. ,Hoes A.W., Bernsen R.M.D., Trienekens P.H., Thomas S., Sturmans F. Effectiveness of diabetes peer education for Turkish type 2 diabetes patients on glycaemic control: a controlled experiment in general pracice. (submitted).

Universiteit van Humanistiek (2001). Zin in Gezond Leven. Projectvoorstel in het kader van het Programmam Gezond Leven van ZonMw. Utrecht: Universiteit van Humanistiek.

Verrept, H. (1995). Evaluatie van het project 'Interculturele bemiddelaars in de gezondheidszorg', proefschrift faculteit Medisch-Sociale Wetenschappen, Vrije Universiteit Brussel

Voorham A.J.J., Reelick N.F.(1986). De rol van procesonderzoek bij een GVO-actie. Tijdschrift Gezondheidsbevordering,7, . 4: 17-26.

Voorham A.J.J., Kocken P.L. (2000) Kenmerken van de voorlichter bij het effect van seniorenvoorlichting: een kwantitatieve procesevaluatie. TSGI Tijdschrift voor gezondheidswetenschappen; 78, 5: 303-308.

Voorham A.J.J., Uitewaal P.J.M., Hoop T de. (2001), Voorlichting in de eigen taal aan Turkse diabetespatiënten; het effect op bloedsuikerwaarden, de ervaren zorg en gedrag. SEGV-rapport 4, Den Haag: Zon/Mw. 
Voorham A.J.J., Uitewaal P.J.M., Bruijnzeels M. (2002) Het effect van voorlichting in de eigen taal aan Turkse diabetespatiënten, een experiment in de eerste lijn. TSGI Tijdschrift voor gezondheidswetenschappen; 80, 8: 514-520.

Voorham A.J.J., Kocken P.L., Brandsma J., van Haastrecht P. (2002) Opvattingen over voorlichting en de voorlichter in de eigen taal bij Turkse en Marokkaanse mannen na voorlichting over Aids. TSG/ Tijdschrift voor gezondheidswetenschappen; 80, 2: 110-114.

Voorham A.J.J., De Haes W.F.M., Mackenbach J.P. (2002). Wijkgericht werken aan gezondheidsbevordering in vier achterstandswijken in Rotterdam. Leerpunten uit de praktijk. TSG, Tijdschrift voor gezondheidswetenschappen, 80, 7: 431-5.

Vries, N.K. de. (2000). Het hart, de ruggengraat en de hersenpan. Perspectieven op gezondheidsgedrag. Inaugurele rede, 9 november 2000, Universiteit Maastricht.

Wagemakers M.A.E., van Woerkom C.M.J., Alewijnse D. (2001) De factor sekse bij communicatiemodellen voor de gezondheidszorg. TSGI Tijdschrift voor gezondheidswetenschappen. 79: $143-9$

Wagemans M., de Zwart O., Sandfort Th. (1998) Sexplain: een peerproject over seksuele gezondheid voor jongeren. Eindrapportage. GGD Rotterdam e.o..

Zorg Onderzoek Nederland/ Medische Wetenschappen (ZonMw). (2000) MIV: de factor sekse in de gezondheidszorg. Den Haag, ZonMw

ZonMw (1998). Het programma Preventie 1998-2002. Den Haag, ZonMw.

ZonMw (2001). Overzicht van gehonoreerde projecten van het Programma Preventie 1998-2002. Den Haag, ZonMw. 
a

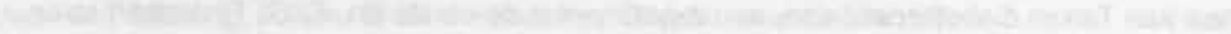

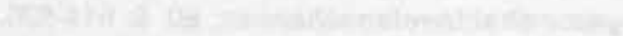

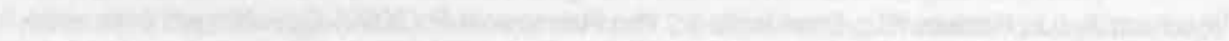

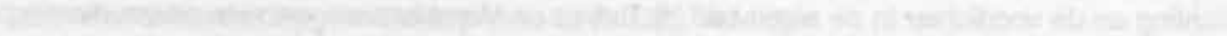

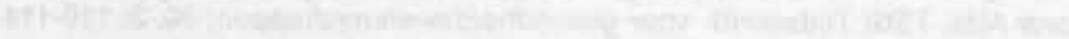

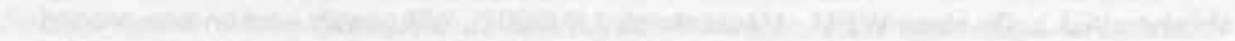

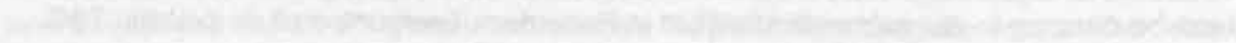

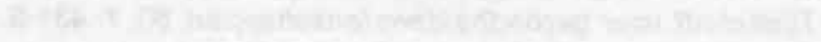

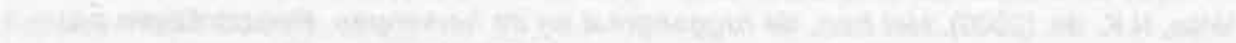
and

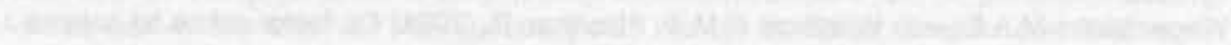

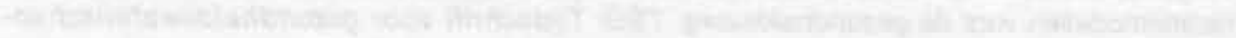
Than

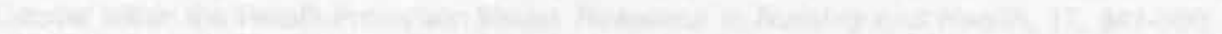

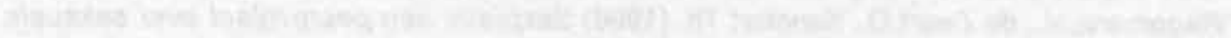

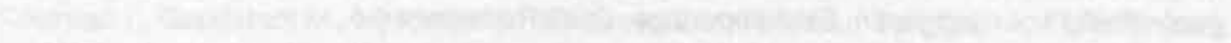

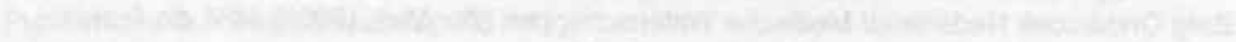

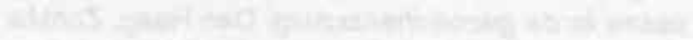

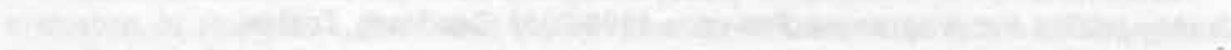




\section{Samenvatting}

In dit proefschrift worden drie projecten op het gebied van gezondheidsbevordering gerapporteerd waarbij gebruik is gemaakt van de voor-en-door methode. Dat wil zeggen dat de doelgroep bij de uitvoering van gezondheidsvoorlichting ingeschakeld is als voorlichter. Project 1 gaat om seniorenvoorlichting waarbij ouderen voorlichting geven over aspecten van ouder worden. In Project 2 geven Turkse en Marokkaanse mannen in de eigen taal Aidsvoorlichting. In het derde project geven Turkse migrantenvoorlichtsters voorlichting over diabetes aan Turkse diabetespatiënten.

In hoofdstuk 1 wordt de theoretische basis van de voor-en-door methode beschreven. Peer voorlichting ofwel de voor-en-door methode is potentieel een effectieve methode. De theoretische basis voor de potentiële effectiviteit van de methode kan vooral gevonden worden in de sociale leertheorie van Bandura en in de sociale vergelijkingstheorie van Festinger. De effectiviteit is echter niet vanzelfsprekend. Er is een risico dat de planmatige benadering van het gezondheidsprobleem minder nadruk krijgt. Ten eerste omdat er zeer veel keuzes gemaakt moeten worden binnen de methode van peer voorlichting voordat er sprake kan zijn van een effectieve praktische strategie. Ten tweede omdat er een voorlichtingsstructuur is ontstaan met steunpuntfunctionarissen en peervoorlichters die snel en efficiënt kunnen worden ingezet om de doelgroep te bereiken, ook als dat theoretisch misschien niet de beste keuze zou zijn. Er moet steeds een antwoord gevonden worden op de volgende vragen. Wie Kan de peer voorlichter voor dit onderwerp in déze context zijn? Waaruit bestaat het peerschap? Wat is de bindende factor tussen de peer en de doelgroep? Een peer voorlichter moet een persoon zijn die in de betreffende context met het betreffende onderwerp een wijgevoel bij de doelgroep kan bewerkstelligen, en tegelijkertijd als persoon een rolmodel kan zijn. De volgende vraag is hoeveel scholing en training de peer voorlichter aangeboden krijgt? Er moet een balans gevonden worden tussen de geloofwaardigheid door betrouwbaarheid (de goede vriend) en geloofwaardigheid door deskundigheid (de expert). In dit volledige spectrum van de peer methode van goede vriend tot expert zitten de migrantenvoorlichters en -sters, en de seniorenvoorlichters erg dicht tegen de expertrol of de paraprofessional aan. In deze drie projecten waarbij peer voorlichting als methode is gebruikt, wordt nagegaan of de methode effectief was en of het 'peerschap' daaraan een bijdrage heeft geleverd.

In hoofdstuk 2 wordt de effectevaluatie van de seniorenvoorlichting (Project 1) beschreven. De cursus 'Succesvol ouder worden' is door seniorenvoorlichters in series van vier bijeenkomsten met ongeveer twintig deelnemers gegeven. Het doel van de cursus was het stimuleren van participatie van ouderen in de samenleving, en het bevorderen van het algemeen welzijn van de ouderen. De effectevaluatie betrof de veranderingen in de houding ten opzichte van het ouder worden, de persoonlijke effectiviteit, de mening over de plaats van de ouderen in de samenleving (de sociale invloed van de ouderen), de sociale participatie, de subjectief ervaren steun, en het subjectief welbevinden van 
de ouderen. De participanten varieerden in leeftijd van 55 tot 79 jaar. In een quasiexperimenteel evaluatieonderzoek is het effect van de cursus op de experimentele groep vergeleken met een controlegroep van ouderen die nog op de wachtlijst stonden voor deeiname aan de cursus. De respondenten hebben op drie momenten een met de post opgestuurde vragenlijst ingevuld: vóór de start van de cursus (t0), onmiddellijk na het einde van de cursus ( $t 1$ ) en drie maanden later ( $t 2)$. Op basis van een multivariate analyse kon een effect van de cursus worden aangetoond op de mening over de sociale invloed de ouderen. Ook de subjectief ervaren sociale steun en de subjectieve gezondheid verbeterde bij de deelnemers aan de cursus, vergeleken met de controlegroep. Er werd drie maanden na de cursus geen effect gevonden op de attitude ten opzichte van het ouder worden, de persoonlijke effectiviteit, sociale participatie en het welzijn.

In hoofdstuk 3 wordt in Project 1 nagegaan of de rol van de seniorvoorlichter zoals gepercipieerd door de respondent én de seksegelijkheid (mannelijke voorlichter met mannelijke respondent en vrouwelijke voorlichter met vrouwelijke respondent) van invloed is op de effectiviteit van de voorlichting. In hoeverre is het subjectieve beeld van de voorlichter en de objectieve seksegelijkheid van invloed op het effect van de voorlichting? Er zijn regressieanalyses uitgevoerd op de data van de experimentele groep met deze twee procesvariabelen als onafhankelijke en de verschilscores van de voormeting $(\mathrm{t} 0)$ en nameting $(\mathrm{t} 1)$ van zes uitkomstvariabelen als afhankelijke variabelen. Geconcludeerd wordt dat vooral seksegelijkheid de effectiviteit van de voorlichting onder voorwaarden voorspelt, vooral bij de hoger opgeleiden, de vrouwen en de ouderen. Een uitzondering op dit patroon vormt de invloed op het 'subjectief welbevinden" en 'oordeel over de eigen gezondheid', waarbij een gunstig beeld van de voorlichter juist geen of een negatief effect voorspelt. Vermoedelijk speelt de vergelijking van de eigen gezondheid met die van de voorlichter daarbij een rol en de objectieve achteruitgang van de gezondheid in de periode tussen de voormeting en de nameting.

In hoofdstuk 4 worden de resultaten van de aidsvoorlichting besproken (Project 2). In dit project zijn Turkse en Marokkaanse mannen getraind om in de eigen taal voorlichting over Aids te geven. De voorlichting werd georganiseerd op de plekken waar de Turkse mannen en de Marokkaanse mannen vaak bij elkaar komen, namelijk in de koffiehuizen. In het evaluatieonderzoek is het effect van de voorlichtingsactiviteiten vastgesteld op de ervaren dreiging van Aids en op de opvattingen over het gebruik van het condoom. De locaties dat wil zeggen de koffiehuizen zijn willekeurig toegewezen aan de experimentele groep en de controle groep. De deelnemers in de experimentele koffiehuizen vulden een korte vragenlijst (een quiz!) in aan het einde van de voorlichtingssessie, terwijl de deelnemers in de controlekoffiehuizen vooraf aan de voorlichtingsactiviteiten de korte vragenlijst invulden. In de analyse is gebruik gemaakt van een multilevel logistische regressieanalyse. Daarmee kon een effect worden vastgesteld op misverstanden en de risicoperceptie met betrekking tot HIV. De ervaren voordelen van de bescherming van het condoomgebruik werden alleen beïnvloed bij mannen van 30 
jaar en ouder. De opvatting over verminderde satisfactie bij condoomgebruik veranderde bij de ongehuwde mannen. De persoonlijke effectiviteit met betrekking tot condoomgebruik verbeterde bij de mannen die de voorlichting in de eigen taal belangrijk vonden. Bij de Marokkaanse mannen was er een effect op de intentie tot condoomgebruik.

In hoofdstuk 5 wordt ingegaan op de rol van de aidsvoorlichter uit Project 2. Bij deze voorlichting in de eigen taal wordt over het algemeen aangenomen dat de voorlichters voldoen aan een behoefte, en dat de doelgroep de voorlichting in de eigen taal op prijs stelt. Verondersteld wordt ook dat de voorlichter dichtbij de doelgroep staat, en dat hij een rolmodel kan zijn voor de doelgroep. Vooral bij een voor de doelgroep controversieel onderwerp als aids is dat niet altijd vanzelfsprekend. Het is goed denkbaar dat het rolmodel wordt 'besmet' door het onderwerp, met als gevolg dat de mening van de doelgroep over de voorlichter negatief wordt beinviloed door het onderwerp dat hij moet bespreken. Nagegaan is of er aanwijzingen zijn voor dit probleem. Ook is nagegaan of de doelgroepen sterk verschillen ten aanzien van hun mening over de voorlichter en voorlichting. Ná de voorlichting vindt driekwart van de deelnemers het belangrijk dat de voorlichter de eigen taal spreekt en de cultuur kent. Dit verschilt niet tussen Turken en Marokkanen. Ook het vertrouwen dat men in de voorlichter heeft, verschilt niet. Wel verschillen Turken en Marokkanen van mening over de vraag of men liever een Nederlander met een tolk als voorlichter heeft. De meeste Marokkanen hebben liever een Nederlander met een tolk, de meeste Turken hebben liever de voorlichter. Een mogelijke verklaring daarvoor is dat Marokkanen vanwege de dialecten ook elkaar vaak met moeite verstaan. De Turken zien de voorlichter minder vaak als een voorbeeld dan de Marokkanen. Er is hierbij een interactie tussen etniciteit en de openheid van de voorlichting. Alleen bij de bijeenkomsten waarbij niet open en bloot over condoomgebruik werd gesproken, zien de Turken de voorlichter minder als voorbeeld dan de Marokkanen. Waar uitgebreid en open over het condoomgebruik werd gesproken, is er geen verschil. Omdat er alleen een vóór - of nameting bij hetzelfde individu is gedaan. kan er over de richting van deze samenhang geen conclusie worden getrokken. Het is mogelijk dat de Turken gevoeliger zijn voor de opstelling van de voorlichter, en dat de bedekte bespreking van het condoomgebruik ertoe leidt dat men de voorlichter niet als voorbeeld ziet. De Turkse voorlichter is dan blijkbaar té voorzichtig geweest. Het kan ook zijn dat de voorlichter weinig aansluiting voelt bij het publiek, en zich minder een voorbeeld voelt, en als resultaat daardoor méér bedekte termen gaat gebruiken. Het is waarschijnlijk dat beide processen tegelijkertijd hebben gespeeld.

Hoofdstuk 6 en 7 gaan over de effectevaluatie van de diabetesvoorlichting (Project 3). Taal - en cultuurverschillen maken het voor de huisarts moeilijk om optimale zorg te verlenen aan migranten met type 2 diabetes mellitus. Het gevolg is relatief slecht ingestelde bloedwaarden bij deze doelgroep. In het diabetesproject hebben Turkse migrantenvoorlichtsters samen met de betrokken huisartsen de Turkse mannelijke en vrouwelijk diabetespatiënten begeleid, en gemotiveerd tot het opvolgen van de adviezen met betrekking tot voeding, bewegen en medicijngebruik teneinde een goed ingestelde 
bloedsuikerwaarde te bereiken. Voor de effectevaluatie is er een gecontroleerd experiment uitgevoerd in 16 huisartspraktijken. Patiënten van zeven praktijken kregen de gebruikelijke zorg plus de toegevoegde voorlichting en begeleiding van de Turkse zorgconsulent. Die begeleiding bestond uit individuele gesprekken, driegesprekken samen met de huisarts en groepsvoorlichtingsbijeenkomsten met lotgenoten. De patiënten van de andere 9 praktijken kregen de gebruikelijke zorg van de huisarts. Voor de evaluatie werden als uitkomstmaten gebruikt: de instelling van de bloedsuikerwaarden ( $\mathrm{HbA} 1 \mathrm{c})$, lipide concentraties (cholesterol, HDL cholesterol, LDL cholesterol and triglyceride), bloeddruk en lichaamsgewicht. Daarnaast werden door een interviewer thuis vragen gesteld over de kwaliteit van de communicatie met de huisarts en de diëtiste, over de gedragsadviezen, vragen over voeding en bewegen, en vragen over de diabetesgerelateerde klachten.

In deze studie zijn alle Turkse diabetespatiënten ingesloten die uitsluitend door de huisarts werden gezien. Er is geen verbetering van de bloedsuikerwaarden bij de patiënten met relatief goed ingestelde bloedsuikerwaarden, maar een bescheiden verbetering bij de patiënten met een verhoogde $\mathrm{HbA1c}$ waarde. Er is geen verbetering bij de mannen zichtbaar, mogelijk doordat de mannen gemiddeld een relatief lage $\mathrm{HbA} 1 \mathrm{c}$ hebben in de nulmeting. Misschien is hier ook sprake van een seksespecifiek effect. De interventie heeft wel een effect gehad op de communicatie met de huisarts en het aantal bezoeken aan de diëtiste. De kwaliteit van de communicatie met de huisarts is voor de vrouwen verbeterd, maar voor de mannen zelfs verslechterd. Met betrekking tot de gedragsadviezen heeft de voorlichting effect gehad bij het voedingsadvies en het advies met betrekking tot bewegen. Bij het aantal eetmomenten is een verbetering zichtbaar bij zowel de interventiegroep als de controle groep. Bij de diabetesgebonden klachten valt het interactie effect met leeftijd en met sekse op: de vrouwen en de jongeren verbeteren het meest. Over het geheel genomen wijzen de meeste uitkomstmaten in een verwachte, gunstige richting. Echt opvallend is dat de effecten vooral zichtbaar worden bij de vrouwen. Dat is reden om aan te nemen dat de gedragsgerichte interventie met de vrouwelijke voorlichtster méér aansluiting heeft kunnen vinden bij de vrouwen dan bij de mannen.

In hoofdstuk 8 worden de conclusies van de drie projecten samengevat en worden aanbevelingen geformuleerd. Voor een groot deel zijn de resultaten van de drie projecten een empirische onderbouwing voor de uitgangspunten van de voor-en-door methode. De resultaten laten zien dat seksegelijkheid van invloed is op de effectiviteit van de voorlichting. Het is gunstiger om de mannen door mannen en de vrouwen door vrouwen te laten voorlichten. Bij de seniorenvoorlichting en de diabetesvoorlichting blijkt dat uit de resultaten; bij de aids-voorlichting was gemengde voorlichting zelfs geen optie. De resultaten laten tegelijkertijd de relativiteit van de 'gelijkheid' zien. De grenzen van gelijkheid zijn niet vastomlijnd. Similariteit is niet hetzelfde is als volledige gelijkheid. De seniorenvoorlichters in dit project behoorden tot de 'jongere' groep onder de ouderen, ze waren relatief hoger opgeleid. In dit geval laten de ouderen zich dus wél aanspreken door personen van iets jongere leeftijd. En juist bij de lager opgeleiden onder de oude- 
ren zagen we een groter effect van de voorlichting. Bij de aids-voorlichting bleek dat de jongeren onder de koffiehuisbezoekers zich minder aangesproken voelden door de aidsvoorlichter. Het is niet duidelijk wat daarvan de oorzaak is. Het kan zijn een gebrekkige aansluiting vanwege de leeftijd, of het kan zijn dat de voorlichter zich vooral richtte op de relatief ouderen. Bij het diabetesproject was de voorlichtster zelf relatief jong en zelf geen diabetespatiënte.

Vanuit een theoretisch perspectief is er in deze drie projecten sprake van een zwak peerschap. Op het continuüm van professionele voorlichter, via de 'lay health advisor' naar de 'échte peervoorlichter', leunen alle drie projecten dicht tegen de professionele voorlichting aan. Het 'peerschap' kan bij de drie projecten op verschillende manieren worden versterkt. Bij de seniorenvoorlichting kan het peerschap beter benut worden door meer gebruik moet maken van ervaringskennis van de ouderen en de voorlichters en de ouderen zelf een grotere rol te geven bij de keuze van thema's en de uitvoering. Ook moet de vraag gesteld worden of de voorlichtingsactiviteiten seksespecifiek georganiseerd kunnen worden. Bij de aidsvoorlichting kan worden gezocht naar de combinatie met andere interventies zodat de methode van de koffiehuisvoorlichting in een bredere context past, die ook over een langere periode kan worden volgehouden. De diabetesvoorlichting kan het beste seksespecifiek worden georganiseerd, en kan versterkt worden door nog meer gebruik te maken van lotgenotencontact.

We kunnen in deze drie projecten geen onderscheid maken tussen een seksespecifiek effect vanwege de sekse van de voorlichter, en een seksespecifiek effect door bijvoorbeeld de gebruikte methode van voorlichten. Het is denkbaar dat de gedragsmodellen die bij de seniorenvoorlichting of de diabetesvoorlichting zijn gebruikt meer aansluiten bij mannen dan bij vrouwen. Over het algemeen zou in de planning van gezondheidsbevordering meer aandacht moeten zijn voor seksespecifieke uitwerkingen van interventies. 


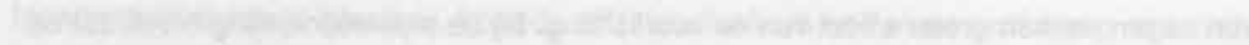

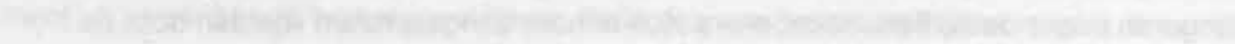
15.

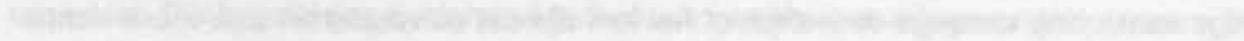
The Than

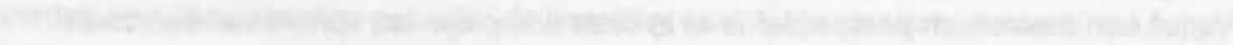

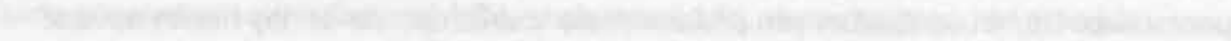

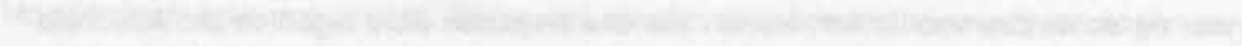
The -

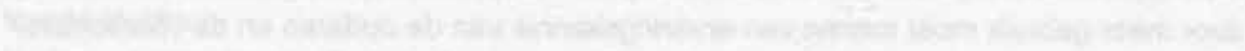

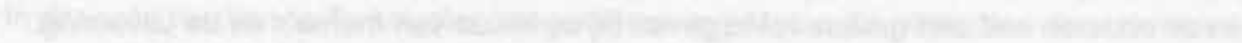
Then

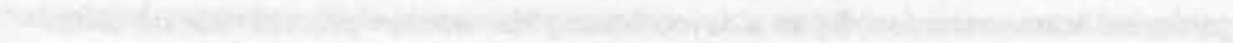

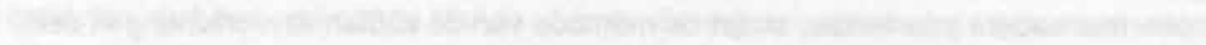

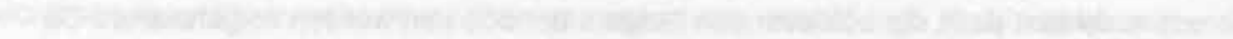
4.

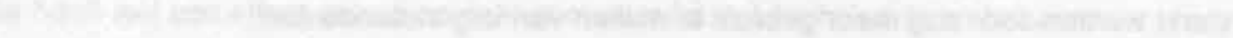

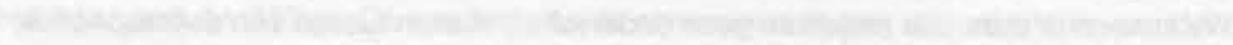

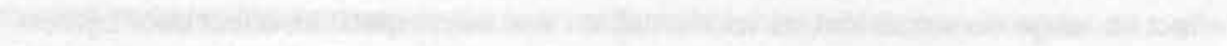

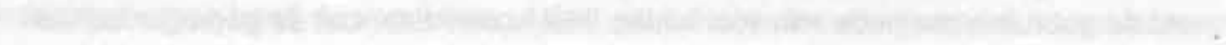

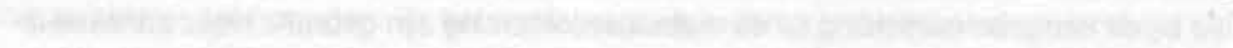

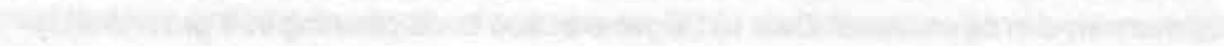




\section{Summary}

Although the popularity as a method in health education is growing, it is unknown why and under which conditions peer education is effective. In this thesis three projects in the field of health promotion in which the peer education method was used, are being reported. In the peer education method members of the target group are actively involved in de delivery of the health promotion activities. In the first project trained senior citizens lead health education sessions on subjects related to growing old with their peer senior citizens as participants. In the second project Turkish and Moroccan male health educators organise Aids education for their peers in their own language and according to their own culture. In the third project Turkish female health educators deliver education related to diabetes for the Turkish diabetes patients.

In chapter one the theoretical foundation of the peer method is formulated. Peer education or in other words the by-and-for method is potentially a powerful method. The theoretical foundation for this potential effectiveness can be found in the learning theory of Bandura and Festinger's theory of social comparison. Although very promising on theoretical grounds, the effectiveness of the method cannot be taken for granted. There is a serious risk that the planned approach of the health problem gets less attention than it should get. First because it's a long way from method to practical strategy. There are a lot of steps and choices to be made before the peer method is an effective health education strategy. Secondly, through the years at the municipal health department of Rotterdam a health education infrastructure of trained peer health educators with a support structure has grown, that can be brought in very quickly and efficiently to reach the different target groups. The possible disadvantage of this availability is a tendency to use this peer strategy although it may not be in all cases the best choice. In the planning process of the peer health education an answer has to be found to the following questions. Which person can be the peer educator in this situation with this specific health subject and this target group? What is his or her 'peership'? In other words, what aspects bind the peer educator with his target group? In all cases a peer educator should be a person that can create a we-feeling with his target group, and at the same time be a role model in the context and with the subject in question. The next important issue is how much training and education should the peer educator get? It is important to find a balance between the credibility as a result of his reliability (the good friend). and the credibility resulting from of his expertise (the expert). In the total range of the peer method, from the good friend up to the expert, the migrant health educators and the senior health educators are closer to the expert role. They are almost paraprofessionals. With these three projects in which the peer method is being used, it has been tested whether the method is effective, and whether the 'peership' has contributed to that effect.

In chapter two the effect of a health education course guided by peers aged 55 and over is evaluated. The aim of the course was to empower older adults to participate in society and to promote their well-being. Evaluation included determining the effect on 
attitude toward ageing, self-efficacy, perception of the societal opinion regarding the place of the elderly in society (social influence), social participa-tion, perceived social support, and well-being of the participants aged 55 to 79 years. A quasi-experimen-tal approach was used. The effect on the experimental group of course participants was studied compared to a control group of older adults on the waiting list. The respondents filled out postal questionnaires at three time points (before starting the course (t0). immedi-ately after termination ( $\mathrm{t} 1$ ) and three months later ( $\mathrm{t} 2 \mathrm{2})$ ). Using a multivariate analysis procedure, a significant interaction effect between time of measurement and group membership was found with respect to the outcome of social influence. At $\mathrm{t} 1$ an effect was absent, but at $\mathrm{t} 2$, the current idea that elderly occupy a marginal position in society, found less favour with the experi-mental group than the control group. Moreover perceived social support and subjective health improved significantly at $\mathrm{t} 1$ and $\mathrm{t} 2$ among the course members, when compared to the control group. No effect was found on attitude, self-efficacy, social participation and well-being in the short time span of a three months follow-up.

In chapter three the evaluation of the peer-led health education program for the elderly (Project 1) has been used to examine the influence of two process variables on the effect of the health education program. The two process variables that are examined are the perceived role of the peer educator (proximity, equality) and the equality of sex of the health educator and the respondent. The question is: Does the perceived role of the peer educator and the equality of gender influence the effectiveness of the health education? The male peer educator has gender-equality with the men, and the female peer educator with the women. Over all there is conditional evidence for the influence of gender-equality on the effect of the programme. The higher educated combine sex-equality with effectiveness. An exception on this pattern is the reverse effect on the outcome variable subjective health and subjective well being when the respondent has a favourable perceived role of the health educator. A possible explanation is an objective deterioration of the health of the older people or a strong reference to the very good health of the peer educator compared with the respondents. Concluded is that this process evaluation produces some empirical evidence for the theoretical foundation of the effectiveness of peer health education

In chapter four an evaluation study is reported into Aids education for immigrants (Project 2) given in their native language by peers. Turkish and Moroccan men were trained to educate people from their own ethnic group. The effect of peer education on the perceived threat of AIDS and beliefs about condom use were studied. Places where male immigrants met, i.e. coffeehouses and mosques, were matched and randomly assigned to experimental and control groups. The experimental group filled out a short questionnaire at the end of the education session (post-test), whereas the control group was pre-tested and had the opportunity of following the AIDS education after participation in the questionnaire. Using multilevel logistic regression analysis, an effect could be established on misunderstandings regarding human immunodeficiency virus (HIV) transmission and risk appraisal for HIV infection. The perceived benefits of the 
protective effect of condom use were affected in men 30 years and older. The perceived barrier of diminished satisfaction if using condoms was changed among unmarried men. Condom self-efficacy was affected in men who valued peer education as important and an effect on intention to use condoms was found among Moroccans.

In chapter five the evaluation of the Aids education in Project 2 has been used to test some assumptions in regard to beliefs about health education and the peer educator. Assumed is that these health educators fulfil a need of the target group, and that the target group appreciates the health education in their own language and according to their own cultural background. Presumed is that the health educator stands close to the target group, and that he can be a role model for his 'peers'. This also should be the case with a controversial subject like Aids. It is conceivable that the role model is being 'stained' or 'contaminated' with the subject of the education. And as a result the opinion of the target group about the health educator will be influenced in a negative way. In this process evaluation is being established that three quarters of the respondents have the opinion that speaking Turkish (Moroccan) by the peer educator and knowing the Turkish (Moroccan) culture is important. The Turks and Moroccans don't differ in that respect. There is also no difference in the perceived reliability of the peer educator. But they do differ in respect to the preference for a Dutch health educator or a peer educator. Most Moroccan men prefer a Dutch educator; most Turks prefer the peer educator. Controlling for age, marital status, educational level and the openness of the aids education session does not change all these results. The Moroccans see the aids educator more often as a role model than the Turks. But that is only the case for the respondents that participated in sessions, in which the use of condoms is not extensively dealt with. There is no difference in the sessions where condom use is extensively discussed. Because of the research design it is not possible to draw a conclusion. Maybe when the Turkish health educator didn't feel very connected to his audience, and didn't feel like a role model, he couldn't start an open discussion.

Chapter six and seven deal with the effect evaluation of the diabetes health education programme (Project 3 ). The language and cultural differences make is very hard for the general practitioner to deliver optimal care to the Turkish migrants with type 2 diabetes mellitus. The consequence is a relatively bad glycaemic control. In this project Turkish female health educators were involved in delivering the health education together with the general practitioner. The migrant health educators motivated the patients to comply to the guidance regarding nutrition, physical exercise and medication, in order to reach a good glycaemic control. The guidance consisted of triangle consultation, individual consultation and group sessions with other Turkish diabetes patients. In the evaluation study a quasi-experimental design was used. Turkish diabetes patients from 7 general practices, who were offered routine care plus additional diabetes peer education, were compared with Turkish diabetes patients from 9 practices offered usual care. In total 16 general practices with 31 participating general practitioners in the inner city of Rotterdam were involved. In the period December 1997 to December 1999, 85 Turkish 
type II diabetes patients were recruited and followed for one year. The main outcome measures were glycaemic control (measured as $\mathrm{HbA} 1 \mathrm{c}$ and fasting plasma glucose), serum lipid concentration (cholesterol, HDL cholesterol, LDL cholesterol and triglyceride), blood pressure and body mass index. These data were registered in the medical files of the general practitioner. Besides that Turkish interviewers conducted home visits with a questionnaire regarding the quality of the communication with the general practitioner and the dietician, the consultations with the health educator, nutrition and physical exercise, medication, and diabetes related complaints. In this study all the diabetes patients that were seen by the general practitioner were included in the experiment. There was no improvement of the glycaemic control (HbA1c) with patients with a relative good control, and a modest improvement with the patients with a high $\mathrm{HbA1c}$ level. There is no improvement with the men, maybe because the men had lower levels at the baseline. Or there is a gender specific effect. Serum lipid concentration, blood pressure and body mass index remained unchanged in the intervention group. The intervention raised the number of visits to the dietician. The quality of the communication with the general practitioner was improved, but only with the women. The men found the quality of the communication with the general practitioner deteriorated. In regard to the behaviour change there was an effect in reported nutrition and in reported physical exercise. There was a change in the number of reported meals in the intervention group as well as in the control group. With the diabetes related complains it's striking there is an interaction effect with age and with gender. The women - again - and the younger in the intervention group improve most, which means they have fewer complaints after the intervention. Over all most outcome measures improve in the desired direction. Striking is that effects are most prominent with the women patients. There is reason to assume that the behaviour directed intervention with the female health educator was better tailored to the women then to the men.

In chapter eight the conclusions of the three projects are summarised and recommendations are formulated, For a large part the result of the three projects constitute an empirical foundation of the peer education strategy. The results show that the equality of gender between the peer educator and the target group is beneficial for the effectiveness of the health education. In general, it is more effective to have the men educate the men, and the women educate the women. With the peer led health education of the seniors and with the diabetes education most of the results point in that direction. With the Aids education mixed groups were not even an option because of cultural rules. At the same time the results show that equality is relative. The boundaries of equality are not clear-cut. Similarity is not the same as total identity. The senior health educators belonged to the younger group amongst the seniors and they were relatively high educated. In this case the elderly stood open for the younger amongst them. And just amongst the lower educated amongst the elderly there was a larger effect of the health education. With the aids education the younger amongst the coffee house visitors were less appealed by the aids educator. And in the diabetes project the women health educator were relatively young and they were not a diabetic themselves. From a theoretical 
point of view in the range from professional health educator to the real peers of the target groups there was a relatively weak 'peership' in this projects. In all projects the educator leans against a professional. In each project the peership can be strengthened in different ways. With the senior health educators more use can be made of the experience of the elderly. The elderly can play a larger role in the choice and execution of the health education. And the health education activities should be organised gender specific. With the aids education one can look for a strategy in which the coffee house sessions are part of a larger strategy that also can be continued for a longer period. The diabetes education should be organised gender specific. And more can be used of companionship by involving more diabetes patients. In this projects we can't make a distinction between a gender specific effect because of the gender of the health educator, and a gender specific effect because of the models and methods that are used. It is conceivable that the behavioural models that are used in project one and three have more connection with the women then with the men. In general in the planning of health promotion more attention should be paid to a gender specific development of interventions. 


\section{Curriculum vitae}

Anthonius Johannes Joachim Voorham werd op 16 augustus 1951 te Maasland geboren. In 1969 behaalde hij het HBS-B diploma aan het Spieringshoek Lyceum te Schiedam. Hij studeerde sociale wetenschappen (sociologie) met specialisatie methoden en technieken van onderzoek aan de RU Leiden. In 1979 studeerde hij cum laude af. Van 1979 tot 1980 was hij wetenschappelijk medewerker bij het Instituut Sociale Geneeskunde RU Leiden. Vanaf 1980 is hij in dienst van de Gemeentelijke Gezondheidsdienst van Rotterdam. Vanaf het begin was hij betrokken bij gedragsgerichte preventie (GVO) voor specifieke doelgroepen zoals migranten en ouderen. Op dit moment is hij hoofd van de afdeling Ontwikkeling en Implementatie van de sector Gezondheidsbevordering van de GGD Rotterdam. 

Bij de voor-en-door methode worden leden van de doelgroep ingeschakeld als voorlichter. In dit proefschrift wordt deze methode voor de toepassing bij gezondheidsbevordering theoretisch onderbouwd en geëvalueerd. In de praktijk van gezondheidsbevordering van de GGD van Rotterdam is de methode toegepast bij drie projecten. Bij de seniorenvoorlichting geven ouderen aan ouderen voorlichting. Bij de aids-voorlichting geven Turkse en Marokkaanse mannen in koffiehuizen voorlichting over aids. Tenslotte geven Turkse voorlichtsters diabetesvoorlichting aan Turkse diabetespatiènten. In deze drie projecten wordt nagegaan of de methode effectief is geweest, en of de similariteit van doelgroep en voorlichter daaraan een bijdrage heeft geleverd. Aannemelijk wordt gemaakt dat seksegelijkheid van voorlichter en deelnemer een effectverhogende conditie is.

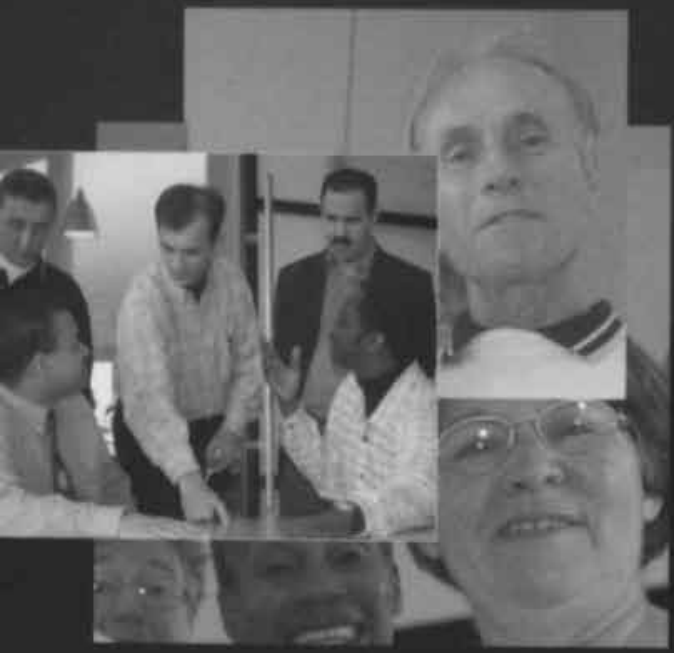

